\section{Pacific Northwest} National Laboratory

Operated by Battelle for the

U.S. Department of Energy

\title{
Groundwater Monitoring at the 1100-EM-1 Operable Unit
}

D. R. Newcomer

April 2007

Prepared for

and the U.S. Department of Energy

under Contract DE-AC05-76RL01830 


\title{
DISCLAIMER
}

This report was prepared as an account of work sponsored by an agency of the United States Government. Neither the United States Government nor any agency thereof, nor Battelle Memorial Institute, nor any of their employees, makes any warranty, express or implied, or assumes any legal liability or responsibility for the accuracy, completeness, or usefulness of any information, apparatus, product, or process disclosed, or represents that its use would not infringe privately owned rights. Reference herein to any specific commercial product, process, or service by trade name, trademark, manufacturer, or otherwise does not necessarily constitute or imply its endorsement, recommendation, or favoring by the United States Government or any agency thereof, or Battelle Memorial Institute. The views and opinions of authors expressed herein do not necessarily state or reflect those of the United States Government or any agency thereof.

\author{
PACIFIC NORTHWEST NATIONAL LABORATORY \\ operated by \\ BATTELLE \\ for the \\ UNITED STATES DEPARTMENT OF ENERGY \\ under Contract DE-AC05-76RL01830
}

Printed in the United States of America
Available to DOE and DOE contractors from the Office of Scientific and Technical Information,
P.O. Box 62, Oak Ridge, TN 37831-0062;
ph: (865) 576-8401
fax: (865) 576-5728
email: reports@adonis.osti.gov

\author{
Available to the public from the National Technical Information Service, \\ U.S. Department of Commerce, 5285 Port Royal Rd., Springfield, VA 22161 \\ ph: (800) 553-6847 \\ fax: (703) 605-6900 \\ email: orders@ntis.fedworld.gov \\ online ordering: http://www.ntis.gov/ordering.htm
}




\title{
Groundwater Monitoring at the 1100-EM-1 Operable Unit
}

\author{
D. R. Newcomer
}

April 2007

Prepared for.

the U.S. Department of Energy

under Contract DE-AC05-76RL01830

Pacific Northwest National Laboratory

Richland, Washington 99352 


\section{Summary}

The Tri-Party Agreement (TPA) record of decision (ROD) presents the selected remedial actions for the former Hanford 1100 Area National Priorities List (NPL) site. This area contains the 1100-EM-1 Operable Unit, one of four operable units identified within the NPL site. Two components of the selected remedy for addressing groundwater in the 1100-EM-1 Operable Unit were:

- Natural attenuation of groundwater that currently exceeds the Safe Drinking Water Act maximum contaminant level (MCL) and monitoring for compliance.

- Continuation of institutional controls for groundwater use at the U.S. Department of Energy's (DOE’s) inactive Horn Rapids Landfill (HRL).

The remedial action objectives identified in the ROD for contaminated groundwater were to:

- Attain the MCL of $5 \mu \mathrm{g} / \mathrm{L}$ for trichloroethene (TCE) at the designated point of compliance. The point of compliance is to be defined by U.S. Environmental Protection Agency (EPA) and Washington State Department of Ecology. Monitoring for compliance will be performed at the defined point.

- Protect environmental receptors in surface waters by reducing groundwater contaminant concentrations in the plume to levels that are safe for biological and human receptors that may be affected at the groundwater discharge point to the Columbia River.

Five wells installed downgradient of the HRL established the point of compliance and the sampling and analysis requirements were identified in the sampling plan. Groundwater monitoring was conducted to confirm the decrease in contaminant levels as predicted in the remedial investigation/feasibility study (RI/FS). The TCE plume was predicted to attenuate to levels less than the MCLs by the year 2017.

The purpose of this report is to provide a comprehensive summary of the distribution and trends of volatile organic compound concentrations near DOE's HRL. This report focuses mainly on the trichloroethene (TCE) plume monitored in the top of the unconfined aquifer near the HRL, but also discusses potential breakdown products of TCE. TCE concentrations in deep portions of the unconfined aquifer and the underlying confined aquifer help to identify the vertical extent of contamination.

This report incorporates TCE data from offsite wells at the AREVA facility south of the Hanford Site. Discussion of TCE in groundwater in the 300 Area is included to differentiate between contaminant plumes and their sources in the 300 Area and near the HRL. Chromium monitoring results from a specific well downgradient of the 1171 Building is also included.

The data presented indicate that TCE contaminant concentrations in the unconfined aquifer have diminished over time near the HRL. The data suggest that the TCE contamination is a result of a onetime release event. The plume mass most likely decreased because of natural attenuation processes, including dispersion and volatilization. By FY 2001, TCE concentrations were less than the 5- $\mu \mathrm{g} / \mathrm{L}$ 
maximum contaminant level in all wells monitored near the HRL area and have continued to remain below the maximum contaminant level through 2006. No degradation products of TCE have been detected in groundwater near the HRL.

Unfiltered chromium concentrations near the 1171 Building have been below the $100-\mu \mathrm{g} / \mathrm{L}$ maximum contaminant level since 1999. Elevated unfiltered chromium concentrations are related to elevated turbidity levels measured during sample collection. Filtered chromium concentrations have been detected at levels near the detection limit, well below the MCL.

During the Hanford Site first 5-year review in 2001, it was concluded that the cleanup levels established for TCE in the ROD were still protective of human health and the environment. In the first 5-year review, it was stated that groundwater contamination continued to attenuate throughout the TCE plume and that the trend in TCE concentrations indicated cleanup levels (the MCL of $5 \mu \mathrm{g} / \mathrm{L}$ ) should be met in 5 to 7 years. During the second 5-year review in 2006, it was concluded that remedies selected for the 1100-EM-1 Operable Unit have been completed. The remedial action objectives established in the ROD have been achieved and are protective of human health and the environment. The 1100 Area has been deleted from the NPL.

It is recommended that annual groundwater monitoring for TCE continue in three wells near HRL: one well at the point of compliance, one well monitoring the top of the unconfined aquifer, and one well monitoring the bottom of the unconfined aquifer immediately downgradient of the HRL. 


\section{Acronyms}

$\begin{array}{ll}\text { DOE } & \text { U.S. Department of Energy } \\ \text { EPA } & \text { U.S. Environmental Protection Agency } \\ \text { HRL } & \text { Horn Rapids Landfill } \\ \text { MCL } & \text { maximum contaminant level } \\ \text { NPL } & \text { National Priorities List } \\ \text { PNNL } & \text { Pacific Northwest National Laboratory } \\ \text { RI/FS } & \text { remedial investigation/feasibility study } \\ \text { ROD } & \text { record of decision } \\ \text { TCE } & \text { trichloroethene } \\ \text { TPA } & \text { Tri-Party Agreement } \\ \text { VOA } & \text { volatile organics analysis }\end{array}$




\section{Contents}

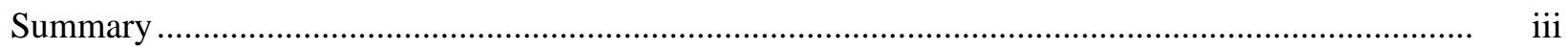

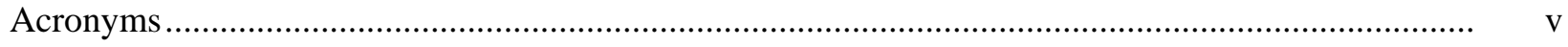

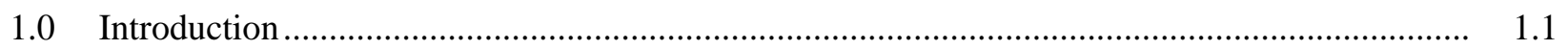

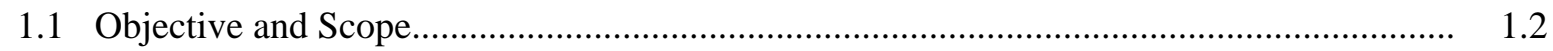

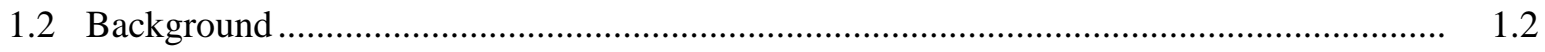

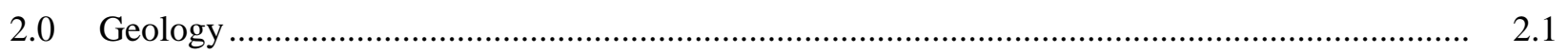

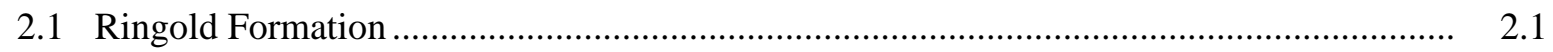

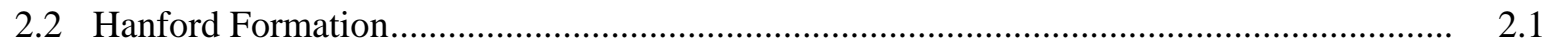

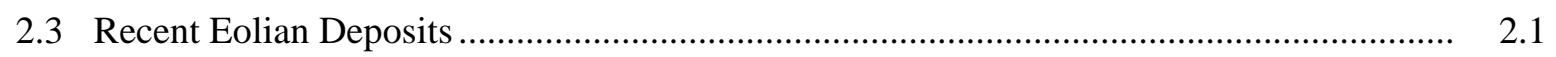

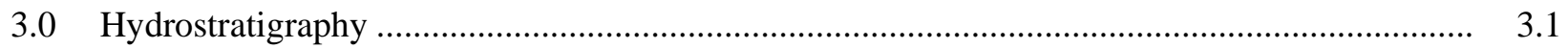

3.1 Vadose Zone .......................................................................................................

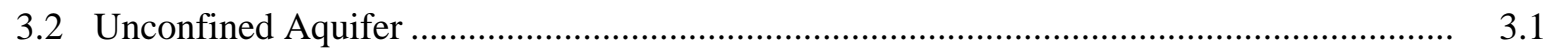

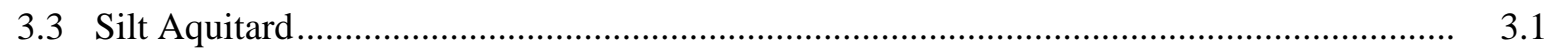

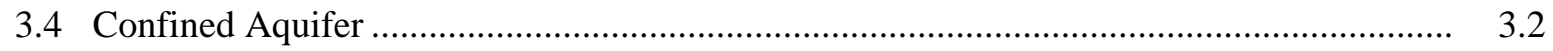

3.5 Lower Clayey Silt to Silty Clay Aquitard ........................................................................ 3.2

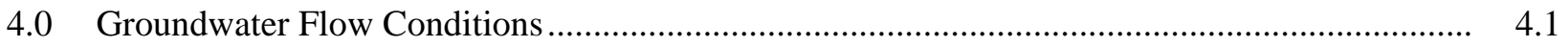

5.0 Sampling and Analysis.................................................................................................. 5.1

5.1 Monitoring Well Network, Constituents, and Monitoring Frequency ............................. 5.1

5.2 Sampling and Analytical Methods ............................................................................. 5.1

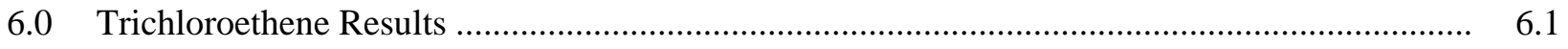

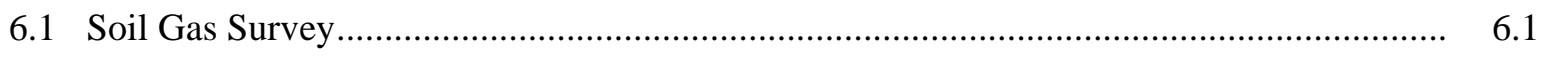

6.2 Trichloroethene Plumes in the Top of the Unconfined Aquifer......................................... 6.1

6.3 Trichloroethene Trends in the Top of the Unconfined Aquifer ......................................... 6.2

6.4 Trichloroethene in Deep Portions of the Unconfined Aquifer .......................................... 6.3

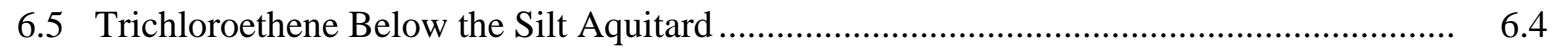

7.0 Trichloroethene Degradation Product Results ......................................................................

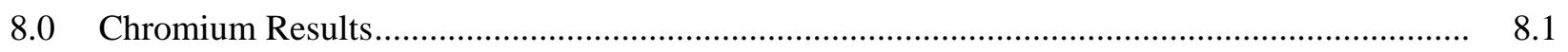

9.0 Conceptual Model ........................................................................................................... 9.1

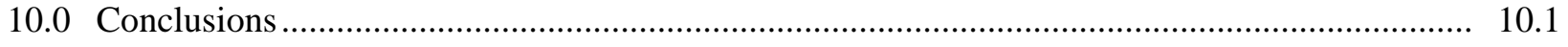

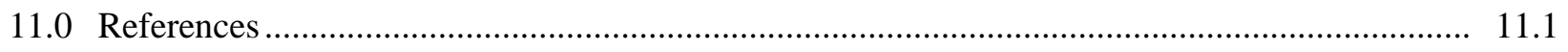

Appendix - Groundwater Analysis Results for the 1100-EM-1 Operable Unit .................................. A.1 


\section{Figures}

1.1 Monitoring Well Locations in the Unconfined Aquifer ........................................................ 1.5

3.1 Generalized Hydrostratigraphic Column of the Horn Rapids Landfill Area ............................... 3.3

4.1 Water-Table Map of the 1100-EM-1 Operable Unit Area, FY 2006 ........................................ 4.3

4.2 Water-Table Map of the 1100-EM-1 Operable Unit Area, June 1990 ..................................... 4.5

4.3 Hydraulic Heads Between the Confined and Unconfined Aquifers West of the

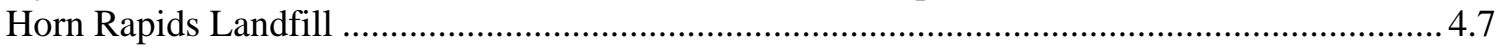

4.4 Hydraulic Heads in the Unconfined and Confined Aquifers East of the Horn Rapids Landfill ....................................................................................................... 4.7

6.1 Average Trichloroethene Concentrations in the Top of the Unconfined Aquifer, FY 1990........6.5

6.2 Average Trichloroethene Concentrations in the Top of the Unconfined Aquifer, FY 1992........ 6.6

6.3 Average Trichloroethene Concentrations in the Top of the Unconfined Aquifer, FY 1994........6.7

6.4 Average Trichloroethene Concentrations in the Top of the Unconfined Aquifer, FY 1996........6.8

6.5 Average Trichloroethene Concentrations in the Top of the Unconfined Aquifer, FY 1998........6.9

6.6 Average Trichloroethene Concentrations in the Top of the Unconfined Aquifer,

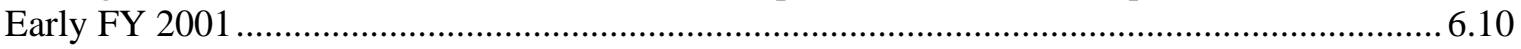

6.7 Average Trichloroethene Concentrations in the Top of the Unconfined Aquifer, FY 2001........6.11

6.8 Average Trichloroethene Concentrations in the Top of the Unconfined Aquifer, FY 2006........6.12

6.9 Average Nitrate Concentrations in the Top of the Unconfined Aquifer, FY 2006 ....................6.13

6.10 Trichloroethene Concentration Trends Adjacent to the Horn Rapids Landfill ...........................6.14

6.11 Trichloroethene Concentration Trends Between the Horn Rapids Landfill and the

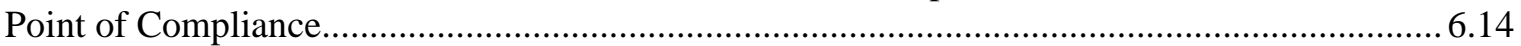

6.12 Trichloroethene Trends Northeast of the Horn Rapids Landfill .............................................. 6.15

6.13 Trichloroethene Trends at the Point of Compliance ................................................................. 6.15

6.14 Monitoring Wells in the Deep Portion of the Unconfined Aquifer............................................6.16

6.15 Trichloroethene Distribution in the Deep Portion of the Unconfined Aquifer ........................... 6.17

6.16 Trichloroethene Trend in the Deep Portion of the Unconfined Aquifer ..................................... 6.18

6.17 Monitoring Wells in the Confined Aquifer ................................................................................ 6.19

6.18 Trichloroethene Distribution in the Confined Aquifer..............................................................20

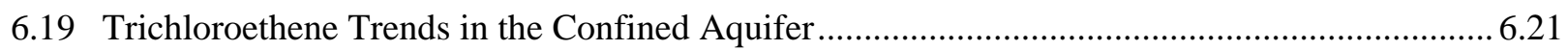

7.1 1,1-Dichloroethene Concentrations Adjacent to the Horn Rapids Landfill ............................... 7.2

7.2 cis-1,2-Dichloroethene Concentrations Adjacent to the Horn Rapids Landfill .......................... 7.2

7.3 trans-1,2-Dichloroethene Concentrations Adjacent to the Horn Rapids Landfill ....................... 7.3

7.4 Vinyl Chloride Concentrations Adjacent to the Horn Rapids Landfill ....................................... 7.3

7.5 1,1-Dichloroethene Concentrations at the Point of Compliance................................................ 7.4

7.6 cis-1,2-Dichloroethene Concentrations at the Point of Compliance ......................................... 7.4

7.7 trans-1,2-Dichloroethene Concentrations at the Point of Compliance ........................................... 7.5

7.8 Vinyl Chloride Concentrations at the Point of Compliance..................................................... 7.5 
7.9 1,1-Dichloroethene Concentrations in the Deep Portion of the Unconfined Aquifer .................. 7.6

7.10 cis-1,2-Dichloroethene Concentrations in the Deep Portion of the Unconfined Aquifer ............ 7.6

7.11 trans-1,2-Dichloroethene Concentrations in the Deep Portion of the Unconfined Aquifer ......... 7.7

7.12 Vinyl Chloride Concentrations in the Deep Portion of the Unconfined Aquifer ........................ 7.7

7.13 1,1-Dichloroethene Concentrations in the Confined Aquifer .................................................. 7.8

7.14 cis-1,2-Dichloroethene Concentrations in the Confined Aquifer............................................... 7.8

7.15 trans-1,2-Dichloroethene Concentrations in the Confined Aquifer .......................................... 7.9

7.16 Vinyl Chloride Concentrations in the Confined Aquifer ........................................................ 7.9

8.1 Filtered and Unfiltered Chromium Concentrations Near the 1171 Building ............................... 8.1

\section{Tables}

5.1 List of Monitoring Wells, Sampled Constituents, and Monitoring Frequency .......................... 5.2

5.2 List of Constituents Analyzed by EPA VOA Method 8260 ................................................... 5.3

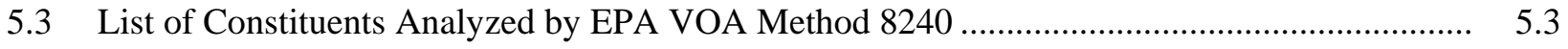

5.4 List of Constituents Analyzed by EPA VOA Method 8010 .................................................... 5.3

5.5 List of Constituents Analyzed by EPA VOA Method 502.2 .................................................. 5.4

5.6 List of Constituents Analyzed by Contract Laboratory Program Volatile Organics Analysis 


\subsection{Introduction}

The Tri-Party Agreement (TPA) record of decision (ROD) (EPA 1993) presents the selected remedial actions for the former Hanford 1100 Area National Priorities List (NPL) site. This area contains the 1100-EM-1 Operable Unit, one of four operable units identified within the NPL site. Two components of the selected remedy for addressing groundwater in the 1100-EM-1 Operable Unit were:

- Natural attenuation of groundwater that currently exceeds the Safe Drinking Water Act maximum contaminant level (MCL) and monitoring for compliance.

- Continuation of institutional controls for groundwater use at the U.S. Department of Energy's (DOE’s) inactive Horn Rapids Landfill (HRL).

The remedial action objectives identified in the ROD for contaminated groundwater were to:

- Attain the MCL of $5 \mu \mathrm{g} / \mathrm{L}$ for trichloroethene (TCE) at the designated point of compliance. The point of compliance is to be defined by U.S. Environmental Protection Agency (EPA) and Washington State Department of Ecology. Monitoring for compliance will be performed at the defined point.

- Protect environmental receptors in surface waters by reducing groundwater contaminant concentrations in the plume to levels that are safe for biological and human receptors that may be affected at the groundwater discharge point to the Columbia River.

Five wells installed downgradient of the HRL established the point of compliance and the sampling and analysis requirements were identified in the sampling plan (DOE 1995a). Groundwater monitoring was conducted to confirm the decrease in contaminant levels as predicted in the remedial investigation/ feasibility study (RI/FS). The TCE plume was predicted to attenuate to levels less than the MCL's by the year 2017 (DOE 1992a, 1992b).

Groundwater monitoring constituents identified in the original sampling plan (DOE 1995a) were:

- Trichloroethene

- 1,1-Dichloroethene

- Vinyl chloride

- Nitrate

- Chromium

Vinyl chloride and 1,1-dichloroethene were identified as TCE breakdown products. Nitrate and chromium were not decision drivers in meeting groundwater remedial objectives. The sampling plan was updated in 1999 to reflect Pacific Northwest National laboratory's (PNNL) responsibility for groundwater monitoring at the 1100-EM-1 Operable Unit (Newcomer 1999). 
During the Hanford Site first 5-year review in 2001 (EPA 2001), it was concluded that the cleanup levels established for TCE in the ROD (EPA 1993) were still protective of human health and the environment. In the first 5-year review, it was stated that groundwater contamination continued to attenuate throughout the TCE plume and that the trend in TCE concentrations indicated cleanup levels (the MCL of $5 \mu \mathrm{g} / \mathrm{L}$ ) should be met in 5 to 7 years. During the second 5-year review in 2006 (DOE 2006), it was concluded that remedies selected for the 1100-EM-1 Operable Unit have been completed. The remedial action objectives established in the ROD have been achieved and are protective of human health and the environment. The 1100 Area has been deleted from the NPL.

\subsection{Objective and Scope}

The purpose of this report is to provide a comprehensive summary of the distribution and trends of volatile organic compound concentrations near DOE's HRL. This report focuses mainly on the TCE plume monitored in the top of the unconfined aquifer near the HRL, but also discusses potential breakdown products of TCE. TCE concentrations in deep portions of the unconfined aquifer and the underlying confined aquifer are discussed to show the vertical extent of contamination. This report incorporates TCE data from offsite wells at the AREVA facility south of the Hanford Site. Discussion of TCE in groundwater in the 300 Area is included to differentiate between contaminant plumes and their sources in the 300 Area and near the HRL. Chromium monitoring results from a specific well downgradient of the 1171 Building is also included.

Section 1.2 provides the background setting of the HRL and a summary of previous investigations. Section 2.0 describes the general geology and includes a geologic cross section across the HRL area. A hydrostratigraphic description and groundwater flow conditions are found in Sections 3.0 and 4.0, respectively. Sampling and analysis of TCE, TCE breakdown products, and chromium are summarized in Section 5.0. Analytical results, plume maps, and trend plots are presented in Sections 6.0 for TCE and in Section 7.0 for breakdown products of TCE. Section 8.0 briefly describes the chromium monitoring results. A conceptual model describing the probable source and movement of TCE in groundwater is summarized in Section 9.0. Finally, the conclusions are presented in Section 10.0. References cited in this report are listed in Section 11.0.

\subsection{Background}

The HRL is located north of Horn Rapids Road near its intersection with Stevens Drive along the southern boundary of the Hanford Site (see Figure 1.1). The HRL, which operated from the late 1940s to the 1970s as an uncontrolled landfill, extends over 20 ha (50 acres) of generally flat terrain within the 600 Area. Originally a borrow pit for sand and gravel, the HRL was used primarily as a disposal site for office and construction waste, asbestos, sewage sludge, fly ash, and, reportedly, numerous drums of unidentified organic liquids (DOE 1990). Five disposal trenches were identified through a study of historical aerial photographs, onsite investigations, and geophysical surveys. Surface debris, consisting of auto and truck tires, wood, metal shavings, soft drink cans and bottles, and other small pieces of refuse, was scattered across the site. A single trench, the westernmost of the identified waste disposal trenches, was posted with signs warning that the trench contained asbestos (DOE 1992a, Vol. 1).

TCE-contaminated groundwater was found upgradient and downgradient of the HRL. A review of all available information indicated that TCE contamination moved onto the Hanford 1100 Area via 
groundwater. AREVA, a facility adjacent to HRL, has investigated soil and groundwater contamination as an independent action in accordance with the Washington State Model Toxics Control Act

(E06-02-2006). The past use of solvents at the AREVA lagoon area was the only documented record of TCE occurrence or use near the contaminant plume identified during the 1100-EM-1 RI/FS (DOE 1992a, 1992b). TCE was used during the installation, repair, and cleaning of lagoon liners at various times from 1978 through 1988 (i.e., for bonding overlapping liner sections together). While the HRL was alleged to have received drummed waste solvents (DOE/RL-90-18), soil-gas surveys, geophysical investigations, and trenching activities during the RI/FS did not reveal any evidence of a TCE source at the HRL (DOE 1992a, 1992b).

The 1100 Area ROD (EPA 1993) established the natural attenuation alternative as the remedial action for the TCE plume. Monitoring to evaluate the success of natural attenuation is performed on an annual basis. Five groundwater-monitoring wells were installed in August 1995 downgradient of the HRL to facilitate compliance evaluation and the remedial action objectives of the ROD. Compliance with the TCE MCL concentration of $5 \mu \mathrm{g} / \mathrm{L}$ had been anticipated by the year 2018 based on model predictions of groundwater flow and contaminant transport.

Site characterization validating natural attenuation as a remedial action at the HRL site, which was part of the 1100-EM-1 Operable Unit, was conducted during the RI/FS in the late 1980s and early 1990s (see DOE 1990, 1992a, 1992b). The RI/FS included geologic logs and cross sections, hydrogeologic studies, contaminant distribution maps, daughter product concentrations, and geochemical parameters. The RI/FS also included contaminant fate and transport modeling and a detailed analysis of remedial technologies.

There are several other published reports that discuss the hydrogeology of these areas. These include the following reports:

- Groundwater monitoring reports published annually (e.g., Hartman et al. 2006)

- $\quad$ RI/FS reports for the HRL and for the 300 Area (e.g., DOE 1992a, 1992b, 1995b)

- Hydrogeologic characterization reports (e.g., Liikala 1994)

- Reports on flow in the upper basalt-confined aquifer system (e.g., Spane and Raymond 1993; Spane and Webber 1995; Thorne 1998) 



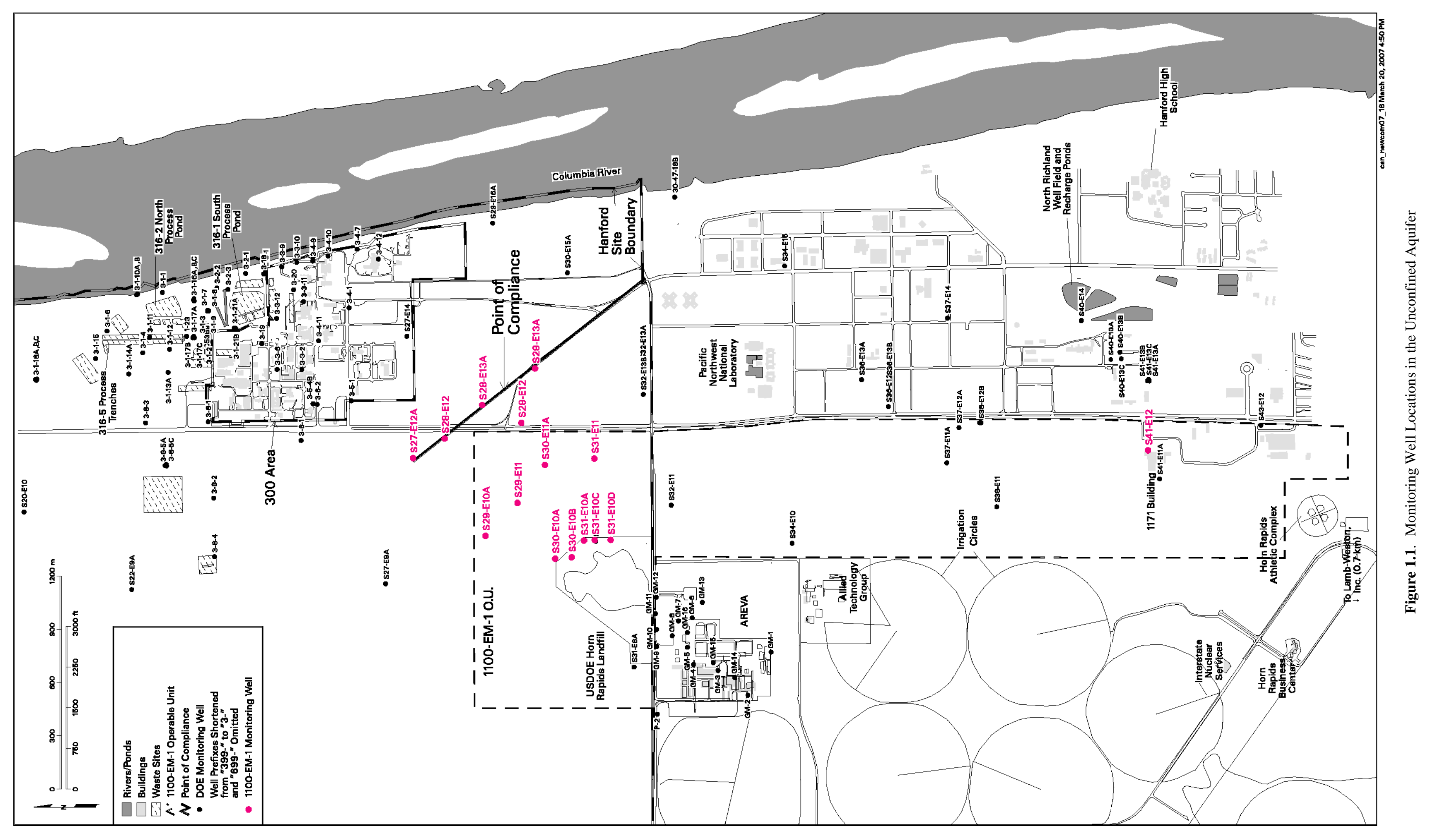




\subsection{Geology}

Stratigraphic units in the HRL area, from bottom to top, the Ringold Formation, the Hanford formation, and Recent (Holocene) eolian surficial deposits, are described in the following sections.

\subsection{Ringold Formation}

The deepest formation penetrated in the HRL area is the Ringold Formation. However, characterization data for the Ringold Formation is limited in this area because only part of the Ringold Formation was penetrated. A fine-grained and coarse-grained facies of the Ringold Formation were penetrated in the HRL area. The overall thickness of the Ringold Formation in the 1100-EM-1 Operable Unit, as reported in DOE (1992a, 1992b), was estimated to be 44 to $52 \mathrm{~m}$ (142 to $171 \mathrm{ft}$ ). This estimate assumed a depth to basalt of $59 \mathrm{~m}(194 \mathrm{ft})$.

The fine-grained facies of the Ringold Formation consists of clay, silt, sandy silt, and sand and represents overbank and lacustrine floodplain deposits. The upper part of the fine-grained facies consists of a clayey silt paleosol. The top of the paleosol is separated from the overlying coarse-grained facies by an erosional surface, or disconformity. The paleosol consists of overbank deposits that were subsequently altered by chemical weathering (DOE 1992a, 1992b). The clayey silt ranges in thickness from $\sim 1$ to $10 \mathrm{~m}$ ( $\sim 3.3$ to $33 \mathrm{ft}$ ) near the HRL. Sediments encountered below the clayey silt include silty gravel and silty sandy gravel.

The upper part of the Ringold Formation consists of inter-fingering sandy gravels, gravelly sands, silty sandy gravels, and silty gravelly sands, with discontinuous sand lenses (DOE 1992a, 1992b). This coarse-grained facies represents high-energy, fluvial deposits in meandering river channels and range in thickness from $2.07 \mathrm{~m}(6.8 \mathrm{ft})$ on the west side of the HRL to $13.41 \mathrm{~m}(44.0 \mathrm{ft})$ on the east side of the HRL (DOE 1992a, 1992b). On the east side of the HRL, a distinctive ash layer of limited areal extent occurs within these coarse-grained sediments. The maximum ash thickness penetrated was $7.04 \mathrm{~m}$ (23.1 ft). Apparently, the ash was an air fall deposit that was subsequently reworked by fluvial processes and deposited into a depression on the top of the underlying sediments.

\subsection{Hanford Formation}

The Hanford formation unconformably overlies the Ringold Formation at the HRL and consists of a mixture of boulders, cobbles, pebbles, sands, and silts. The Pasco gravels, which are the dominant facies of the Hanford formation in the HRL area, were deposited on an irregular erosional surface of the Ringold Formation during Pleistocene glaciofluvial flooding. Most of these gravels are classified as unconsolidated sandy gravels to gravelly sands and silty sandy gravels with moderate to poor sorting. The thickness of the Pasco gravels ranges from $3.32 \mathrm{~m}(10.9 \mathrm{ft})$ to $12.50 \mathrm{~m}(41.0 \mathrm{ft})$ in the HRL area (DOE 1992a, 1992b).

\subsection{Recent Eolian Deposits}

Recent (Holocene) eolian surficial deposits locally form a thin unit overlying the Hanford formation near the HRL. These deposits range in thickness from zero at the HRL to $1.68 \mathrm{~m}(5.5 \mathrm{ft})$ northeast of the HRL and consist of wind-transported sand or silty sand (DOE 1992a, 1992b). 


\subsection{Hydrostratigraphy}

A generalized hydrostratigraphic column of the HRL area is presented in Figure 3.1. The hydrostratigraphy of the HRL area was reported to consist of, from top to bottom, the vadose zone, an unconfined aquifer, a silt aquitard, a confined aquifer, and a lower clayey silt to silty clay unit that overlies basalt bedrock.

\subsection{Vadose Zone}

The vadose zone consists of unsaturated sediments between the ground surface and the water table. This zone occurs predominantly within sandy gravel, gravelly sand, and silty sandy gravel of the Hanford formation. A thin veneer of Recent eolian deposits consisting of sand and silty sand overlies the Hanford formation near the surface. In some areas, the Ringold Formation extends above the water table into the lower part of the vadose zone. The thickness of the vadose zone ranges from $5.1 \mathrm{~m}(16.8 \mathrm{ft})$ on the west side of the HRL to $12.9 \mathrm{~m}$ (42.4 ft) near Stevens Drive to the northeast of the HRL. The thickness of the vadose zone at the AREVA facility ranges from $3.1 \mathrm{~m}(10.1 \mathrm{ft})$ near the center of the facility to $9.9 \mathrm{~m}$ (32.3 ft) in the northeastern corner of the facility along Horn Rapids Road.

\subsection{Unconfined Aquifer}

The unconfined aquifer near the HRL occurs between the water table and the underlying silt aquitard. The unconfined aquifer lies predominantly within sands and gravels of the Hanford and Ringold formations (DOE 1992a, 1992b). However, the Hanford formation is generally coarser-grained and less cemented than the Ringold Formation. Much of the upper few meters of the unconfined aquifer consist of a variable mixture of boulders, cobbles, pebbles, sands, and silts of the Hanford formation. Most of these sediments are generally characterized as unconsolidated sandy gravels, gravelly sands, and silty sandy gravels of the Pasco gravels facies. Within much of the unconfined aquifer near the HRL, the Hanford formation unconformably overlies coarse-grained sediments of the Ringold Formation. These coarsegrained sediments are characterized as poorly- to moderately-consolidated sandy gravels, gravelly sands, silty sandy gravels, and silty gravelly sands with discontinuous sand lenses. The thickness of the unconfined aquifer varies from $5.6 \mathrm{~m}$ (18.4 ft) on the west side of the HRL to $9.0 \mathrm{~m}(29.5 \mathrm{ft})$ near Stevens Drive to the northeast of the HRL.

The presence of the Hanford/Ringold contact within the unconfined aquifer is important for controlling unconfined groundwater flow because hydraulic properties (e.g., hydraulic conductivity) tend to be much higher in the Hanford formation than in the Ringold Formation. Near the HRL, horizontal hydraulic conductivity of the Hanford formation was estimated to be 400 to $520 \mathrm{~m} / \mathrm{d}$ (1,300 to 1,700 ft/d) (DOE 1992a, 1992b). Horizontal hydraulic conductivity of the Ringold Formation was estimated to be 10 to $72 \mathrm{~m} / \mathrm{d}$ (33 to $240 \mathrm{ft} / \mathrm{d}$ ). Vertical hydraulic conductivity was estimated to be 40 to $50 \mathrm{~m} / \mathrm{d}$ (130 to $160 \mathrm{ft} / \mathrm{d}$ ) within the Hanford formation and 2 to $5 \mathrm{~m} / \mathrm{d}$ (7 to $16 \mathrm{ft} / \mathrm{d}$ ) within the Ringold Formation.

\subsection{Silt Aquitard}

The silt aquitard, which consists predominantly of silt, lies entirely within the Ringold Formation below the unconfined aquifer (DOE 1992a, 1992b). The thickness of the silt aquitard in the area of the 
HRL ranges from $\sim 1 \mathrm{~m}(3.3 \mathrm{ft}$ ) to $\sim 10 \mathrm{~m}$ (33 ft). The silt aquitard changes in thickness due to undulations in its upper surface. On the west side of the HRL, the thickness of the aquitard is $\sim 10 \mathrm{~m}(33 \mathrm{ft})$. In one location on the east side of the HRL, the silt aquitard is only $\sim 1 \mathrm{~m}(3.3 \mathrm{ft})$ thick. The silt aquitard at this location is overlain by $\sim 7 \mathrm{~m}$ ( $23 \mathrm{ft}$ ) of volcanic ash, which consists of fine-grained sand.

The silt aquitard was consistently encountered in the HRL area in the deeper boreholes drilled (DOE 1992a, 1992b). The undulating upper surface of the silt aquitard and the high-energy sands and gravels overlying it indicate that the upper surface was subjected to erosion. Because of this erosional surface (disconformity), the potential exists for complete erosion of the silt in localized areas. The silt aquitard is, at least partially, discontinuous to the east of the HRL near the Columbia River. The bottom surface of the aquitard shows a uniform grade in elevation.

Hydraulic property values of the silt aquitard are several orders of magnitude less than in the overlying unconfined aquifer. Horizontal hydraulic conductivities of the aquitard were estimated to be 0.001 to $0.03 \mathrm{~m} / \mathrm{d}(0.003$ to $0.1 \mathrm{ft} / \mathrm{d})$ and vertical hydraulic conductivity values were estimated to be 0.0001 to $0.003 \mathrm{~m} / \mathrm{d}(0.0003$ to $0.01 \mathrm{ft} / \mathrm{d})$ (DOE 1992a, 1992b).

\subsection{Confined Aquifer}

A confined aquifer immediately underlies the silt aquitard within the Ringold Formation. However, information on the nature and extent of this aquifer is limited because only two boreholes (699-S31-E10E and 699-S32-E8) penetrated through the silt aquitard in the HRL area. This confined aquifer lies within sediments consisting of silty gravels and silty sandy gravels. No boreholes penetrated the full thickness of the confined aquifer in the HRL area. Horizontal hydraulic conductivity was estimated to be $0.034 \mathrm{~m} / \mathrm{d}$ $(0.11 \mathrm{ft} / \mathrm{d})$ on the west side of the HRL (DOE 1992a, 1992b).

\subsection{Lower Clayey Silt to Silty Clay Aquitard}

Clayey silt to silty clay aquitard is assumed to overlie the basalt bedrock surface beneath the HRL area (DOE 1992a, 1992b). Boreholes drilled in this area did not penetrate through the confined aquifer to confirm this assumption. However, this aquitard was encountered in the 300 Area to the northeast. In places, thin sand separates the aquitard from the basalt bedrock. 
Thickness Range

(meters)

$5-13$

$6-9$

$1-10$

not determined

in 1100 Area

not determined in 1100 Area

LEGEND:

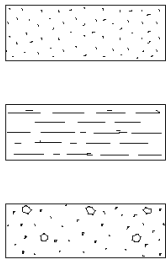

Sand

Silty Sand

Sandy Gravel/Gravelly Sand
Hydrogeologic Units
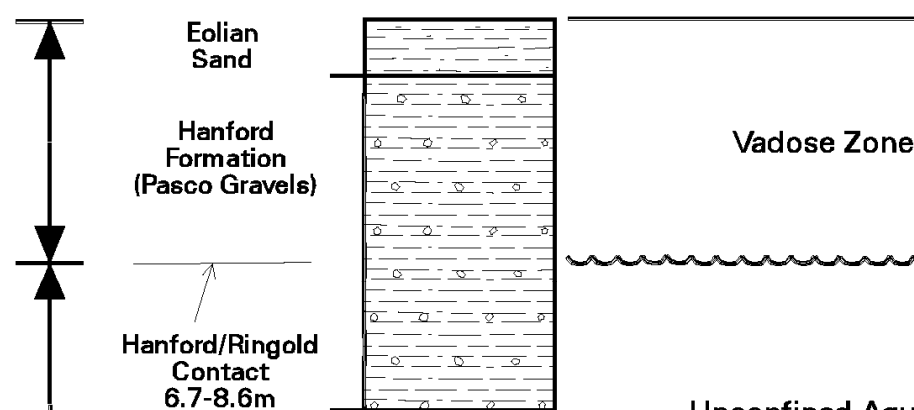

Unconfined Aquifer

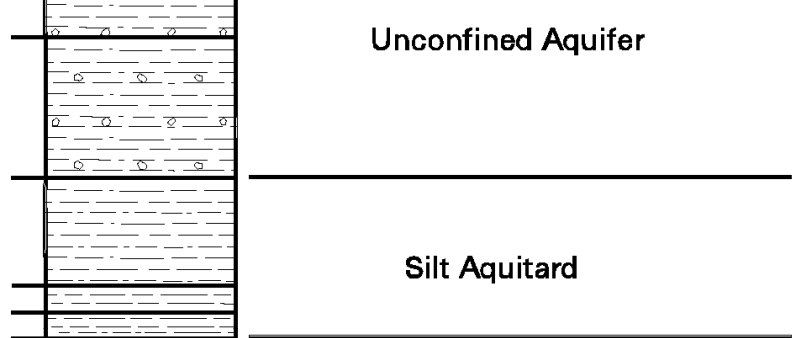

Ringold Formation

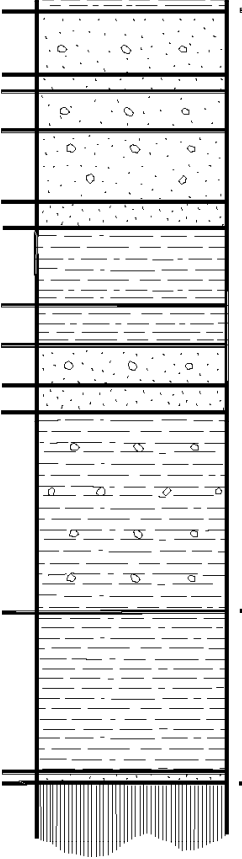

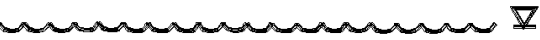

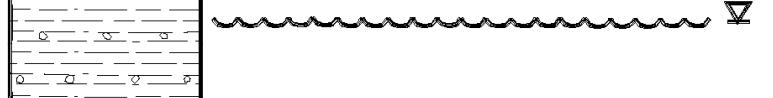

Silt Aquitard

Confined Aquifer

Lower Silt Aquitard

Saddle Mountains Basalt

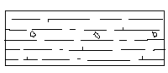

Silty Sandy Gravel/Silty

Gravelly Sand

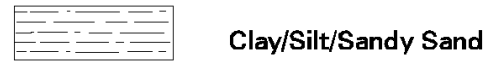

Clay/Silt/Sandy Sand

Basalt

Figure 3.1. Generalized Hydrostratigraphic Column of the Horn Rapids Landfill Area (adapted from DOE 1992a, 1992b) 


\subsection{Groundwater Flow Conditions}

A water-table map of the area between the HRL area and the Columbia River for 2006 is shown in Figure 4.1. The contours on this map generally represent the upper several meters of the top of the unconfined aquifer. Groundwater in this area generally flows from the Yakima River, located several kilometers west and southwest of the HRL area, and discharges to the Columbia River. In the HRL area, groundwater flows northeast and converges with groundwater entering the 300 Area before discharging to the Columbia River. The rate of groundwater flow in the upper part of the unconfined aquifer is estimated to range between 2.4 and $5.0 \mathrm{~m} / \mathrm{d}$ (7.9 to $16.4 \mathrm{ft} / \mathrm{d})$ in the HRL area. This assumes a porosity of 0.20 to 0.33 (DOE 1992a, 1992b), a horizontal hydraulic gradient of 0.002 (using 2006 water-table contours), and a horizontal hydraulic conductivity range of 400 to $520 \mathrm{~m} / \mathrm{d}$ (1,300 to 1,700 ft/d).

Historic water-table maps indicate a consistent northeasterly groundwater flow direction in the vicinity of the HRL. This is illustrated by the water-table map for 1990 (Figure 4.2).

Irrigation of agricultural fields to the southwest has affected groundwater levels seasonally in the HRL area. Agricultural irrigation supplied primarily by the Columbia River recharges the unconfined aquifer between the Yakima and Columbia Rivers. Agricultural irrigation began in 1989, but irrigation was expanded in the early 1990s (Liikala 1994). Columbia River fluctuations have affected groundwater levels near the HRL. As reported in DOE (1992a, 1992b), the influence by seasonal river stage fluctuations extends to approximately the downgradient boundary of the HRL.

The potential for groundwater to move between the unconfined aquifer and underlying confined aquifers is controlled by the vertical hydraulic gradient. This is a controlling mechanism for the potential vertical movement of contaminants. The vertical hydraulic gradient between the unconfined aquifer and the confined aquifer underlying the silt aquitard can be determined by evaluating hydraulic heads in well pairs monitoring each of these aquifers. Two well pairs monitor the unconfined and confined aquifers in the HRL area, one on the west side of the HRL and one on the east side of the HRL. The hydraulic head differences between these aquifers indicate a consistent, but upward hydraulic gradient of approximately $2 \mathrm{~m}$ (6.6 ft) west of the HRL (Figure 4.3). Figure 4.3 shows that the upward gradient has increased slightly since monitoring began in 1990 .

On the eastern edge of the HRL where the silt aquitard thins, the vertical hydraulic gradient ranges from zero to a downward gradient of approximately $0.2 \mathrm{~m}(0.7 \mathrm{ft})$ (Figure 4.4). This indicates that there is no upward flow into the silt aquitard at this well location. DOE (1992a, 1992b) referred to this hydraulic gradient as an "anomaly" compared to vertical hydraulic gradients observed in other well pairs in or near the 1100-EM-1 Operable Unit. 


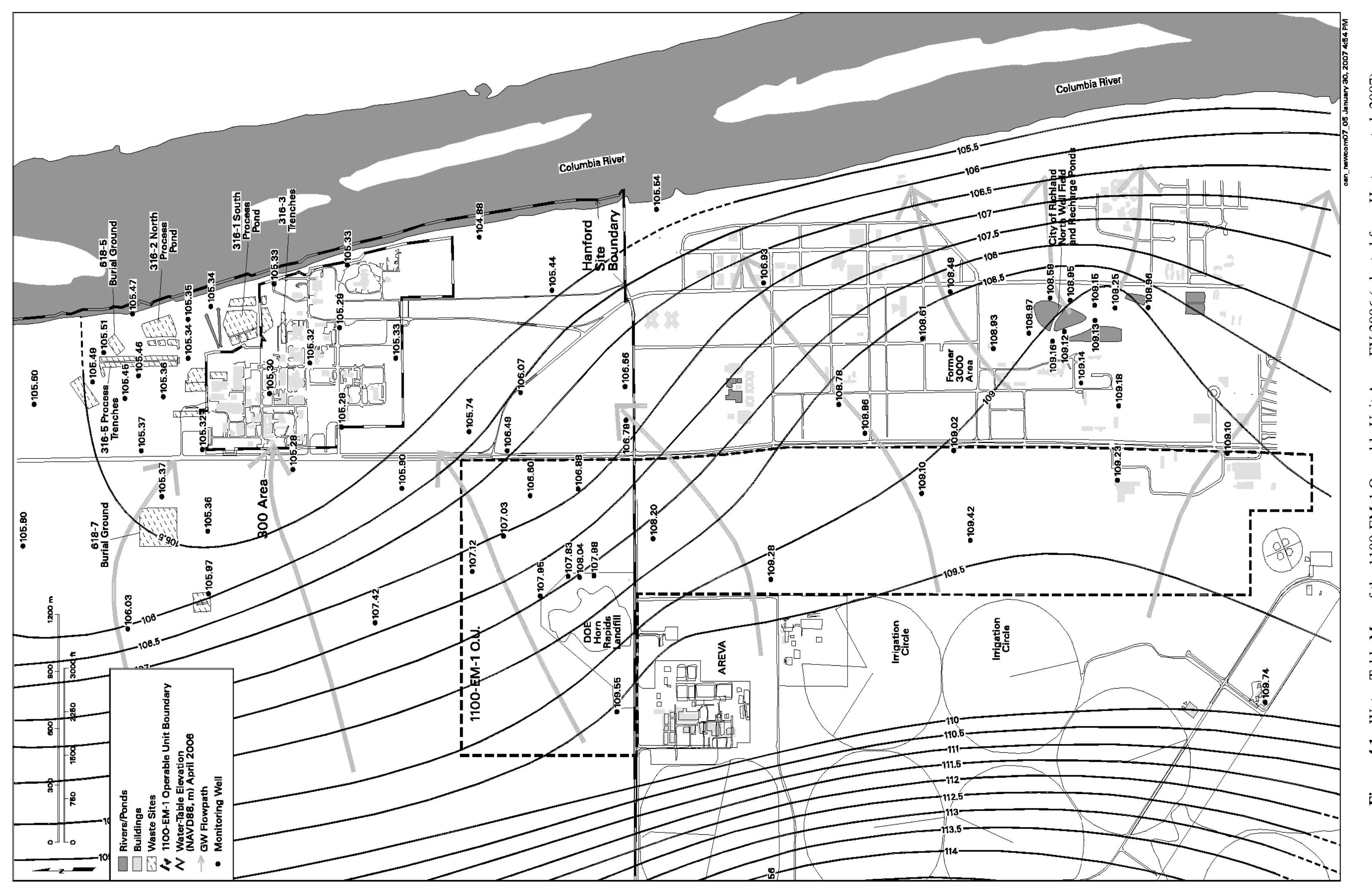

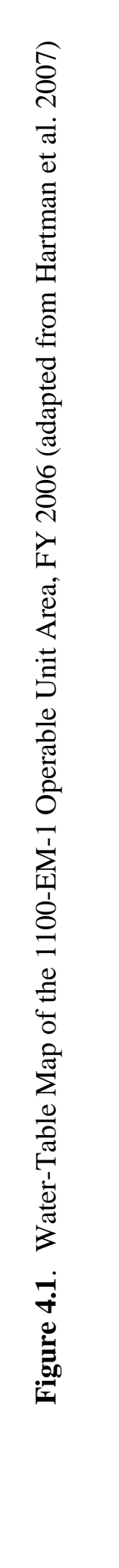




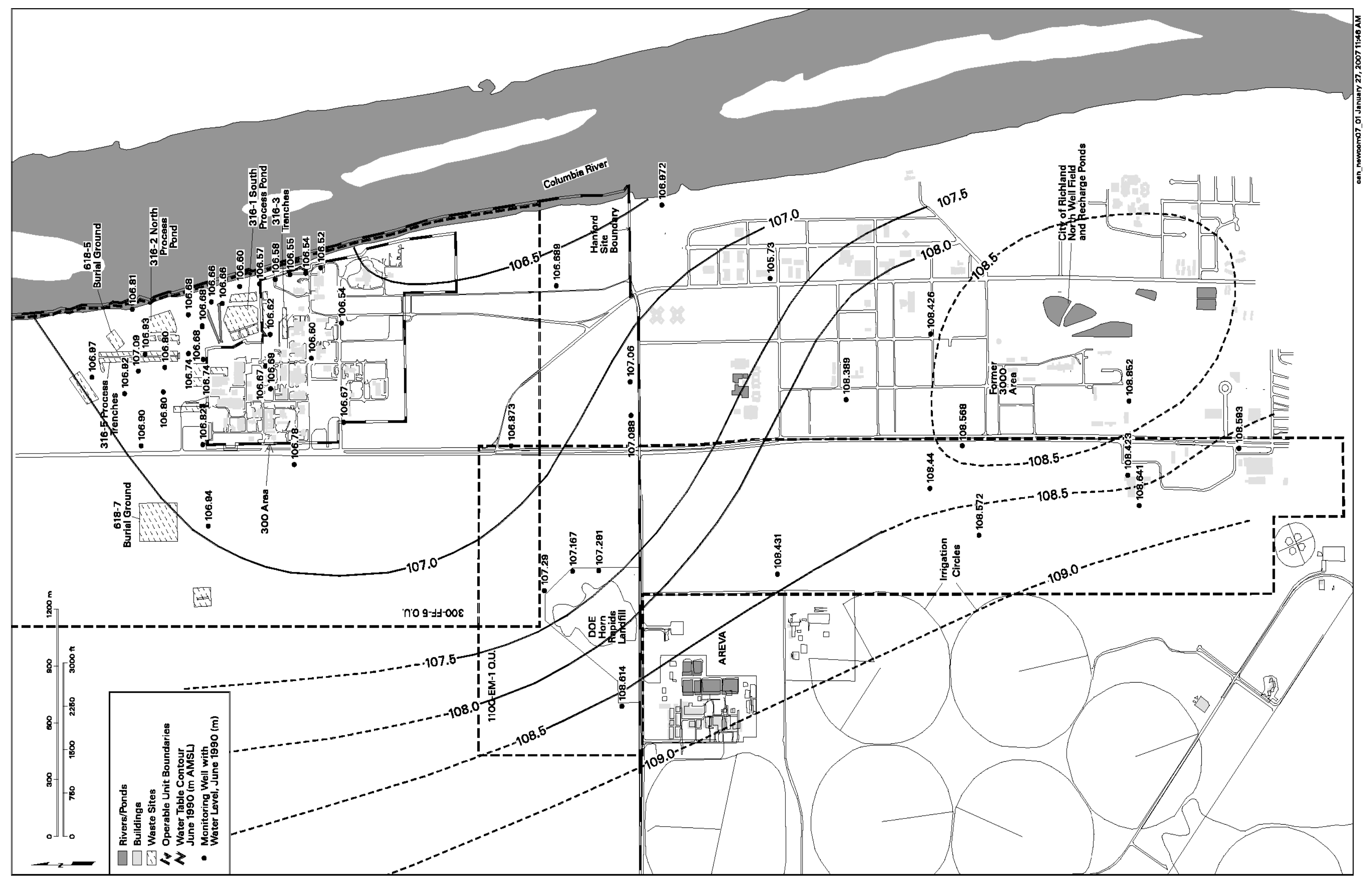




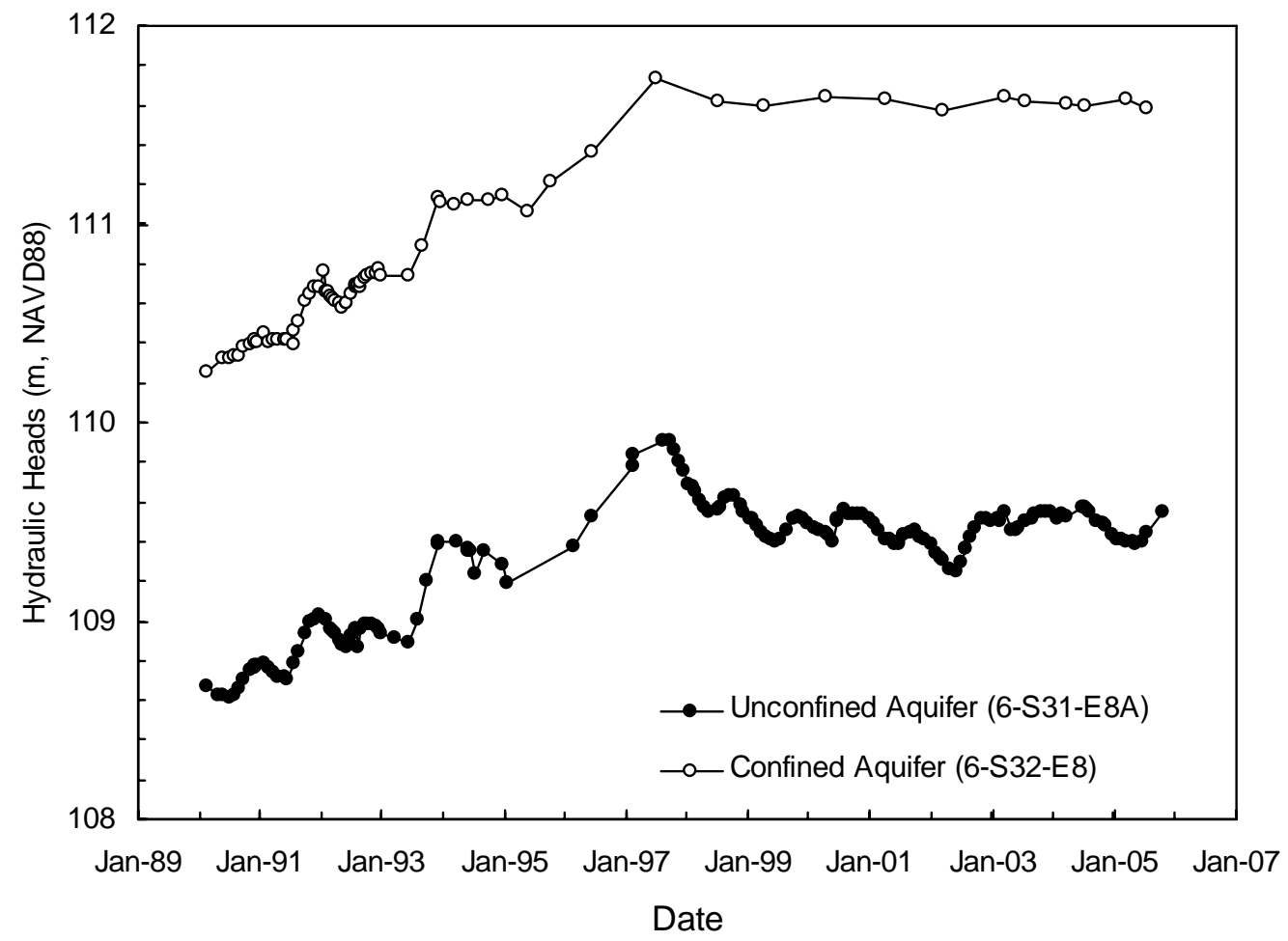

Figure 4.3. Hydraulic Heads Between the Confined and Unconfined Aquifers West of the Horn Rapids Landfill

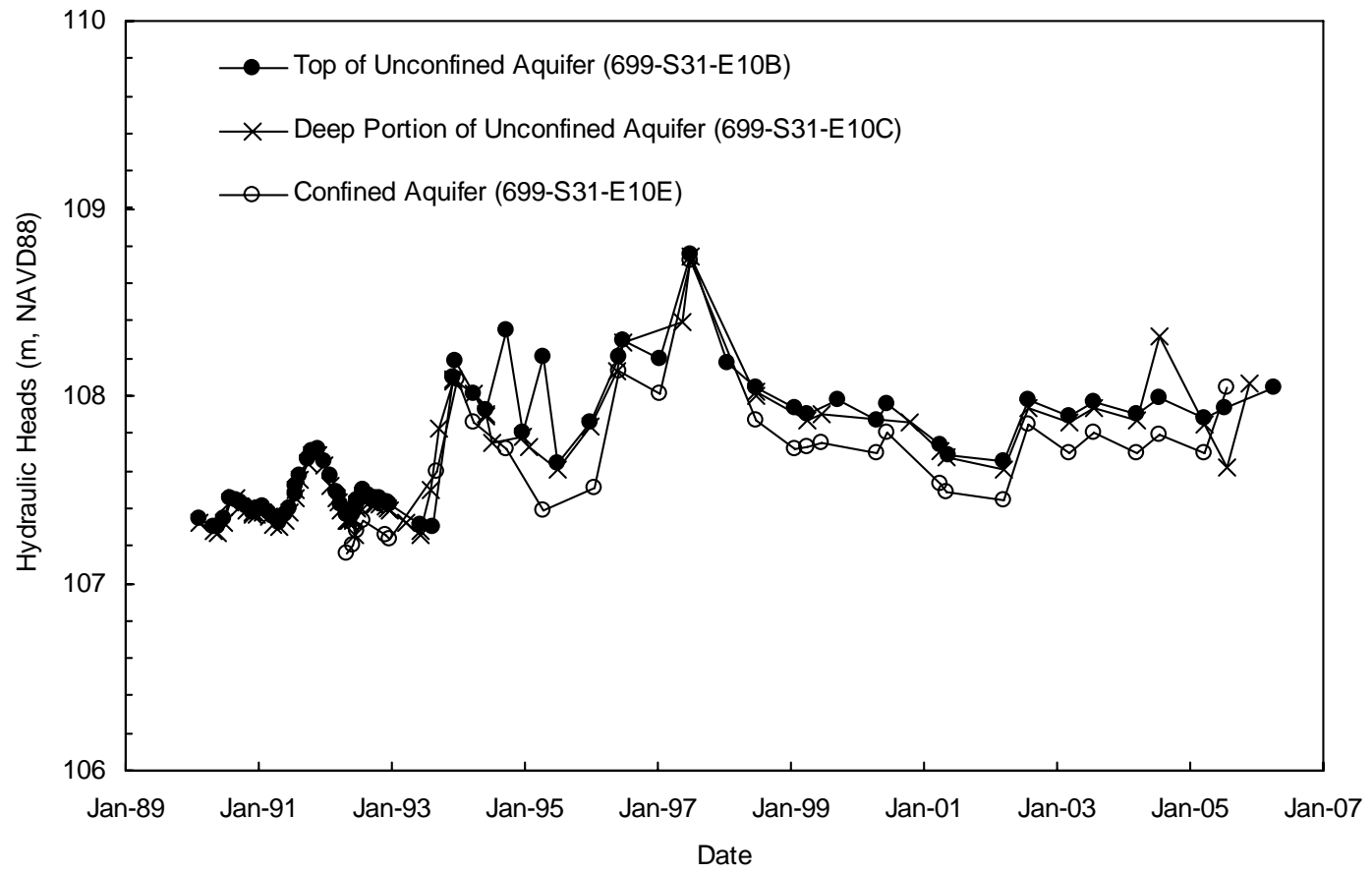

Figure 4.4. Hydraulic Heads in the Unconfined and Confined Aquifers East of the Horn Rapids Landfill 


\subsection{Sampling and Analysis}

\subsection{Monitoring Well Network, Constituents, and Monitoring Frequency}

Table 5.1 lists the monitoring wells, constituents analyzed, and monitoring frequency. The location of the monitoring wells is shown in Figure 1.1. The monitoring wells near the HRL were analyzed on a quarterly and annual frequency. Quarterly sampling was conducted in the wells between 1990 and 1994. After 1994, annual sampling was adequate for monitoring the TCE contamination (DOE 1995a). The sampling plan identified point-of compliance monitoring of the TCE contamination downgradient of the HRL, which is shown in Figure 1.1 (DOE 1995a; Newcomer 1999).

The sample interval of the wells immediately downgradient of the HRL is $\sim 5$ to $7 \mathrm{~m}$ (16.4 to $23 \mathrm{ft}$ ) thick and represents the upper $60 \%$ to $70 \%$ of the unconfined aquifer. Wells downgradient of the HRL, where the unconfined aquifer is thinner, are completed over an interval that represents nearly the entire thickness of the unconfined aquifer. One well (699-S31-E10C) monitors the deep portion of the unconfined aquifer above the silt aquitard at a depth of 2.9 to $7.6 \mathrm{~m}$ (9.5 to $25 \mathrm{ft}$ ) below the water table. This depth interval represents the lower $\sim 60 \%$ of the unconfined aquifer. Another well (699-S31-E10E) monitors the middle Ringold unit below a silt aquitard at a depth of 18 to $21 \mathrm{~m}$ (60 to $70 \mathrm{ft}$ ) below the water table. One well near the 1171 Building monitors the upper $~ 70 \%$ of the unconfined aquifer.

The TCE plume near the inactive HRL is currently monitored annually as part of the 1993 ROD requirements for the Hanford 1100 Area 1100-EM-1 Operable Unit (EPA 1993). Additional annual monitoring of TCE is also conducted near this area for the U.S. Department of Energy.

Degradation products of TCE are also monitored annually as part of the ROD requirements. Degradation products monitored include vinyl chloride, 1,1-dichloroethene, cis-1,2-dichloroethene, and trans-1,2-dichloroethene. Cis-1,2-dichloroethene and trans-1,2-dichloroethene, not included in the original sampling plan, were added to the annual monitoring schedule because they are potential TCE breakdown products.

Chromium was identified as a contaminant that exceeded the maximum contaminant level in a specific well downgradient of the 1171 Building (DOE 1995a). The specific well, 699-S41-E12, and 1171 Building is located in the southern part of the 1100-EM-1 Operable Unit (Figure 1.1). The objective of the sampling and analysis for chromium during the first 5-year review period was to continue monitoring the specific well for chromium because of the high variability in the data and its exceedance of the chromium MCL.

\subsection{Sampling and Analytical Methods}

Groundwater sampling, documentation, sample preservation, shipment, and chain-of-custody requirements are described in PNNL or subcontractor procedure manuals and in the quality assurance plan. Samples were collected after three casing volumes of water were purged from the well or after field parameters ( $\mathrm{pH}$, temperature, specific conductance, and turbidity) stabilized. Preservatives were added to the collection bottles before use in the field. Samples were collected using submersible or piston-driven pumps. 
Volatile organic compounds have been analyzed primarily by EPA SW-846 Method 8260 (Table 5.2). Constituents analyzed included TCE and breakdown products 1,1-dichloroethene, cis-1,2-dichloroethene, trans-1,2-dichloroethene, and vinyl chloride. A few of the earlier rounds of samples were analyzed by EPA Methods 8240, 8010, and 502.2 and Contract Laboratory Program volatile organics analysis (VOA). The constituent lists for these methods are provided in Tables 5.3 through 5.6.

Chromium has been analyzed using EPA SW-846 Method 6010B inductively coupled plasma (ICP). A few of the earlier rounds of samples (i.e., 1990) were analyzed by Contract Laboratory Program metals using ICP. Both filtered and unfiltered samples were collected for the analyses. Samples analyzed for filtered metals were filtered in the field.

Table 5.1. List of Monitoring Wells, Sampled Constituents, and Monitoring Frequency

\begin{tabular}{|c|c|c|c|c|c|c|c|}
\hline Well Number & Chromium & Nitrate & $\begin{array}{l}\text { Trichloro- } \\
\text { ethene }\end{array}$ & $\begin{array}{c}\text { 1,1- } \\
\text { Dichloro- } \\
\text { ethene }\end{array}$ & $\begin{array}{l}\text { Vinyl } \\
\text { Chloride }\end{array}$ & $\begin{array}{c}\text { cis-1,2- } \\
\text { Dichloroethene }\end{array}$ & $\begin{array}{c}\text { trans-1,2- } \\
\text { Dichloroethene }\end{array}$ \\
\hline 699-S27-E12A & & Annual & Annual & Annual & Annual & Annual & Annual \\
\hline 699-S28-E12 & & Annual & Annual & Annual & Annual & Annual & Annual \\
\hline 699-S28-E13A & & Annual & Annual & Annual & Annual & Annual & Annual \\
\hline 699-S29-E10A & & Annual & Annual & Annual & Annual & Annual & Annual \\
\hline 699-S29-E11 & & Annual & Annual & Annual & Annual & Annual & Annual \\
\hline 699-S29-E12 & & Annual & Annual & Annual & Annual & Annual & Annual \\
\hline 699-S29-E13A & & Annual & Annual & Annual & Annual & Annual & Annual \\
\hline 699-S30-E10A & & Annual & Annual & Annual & Annual & Annual & Annual \\
\hline 699-S30-E10B & & Annual & Annual & Annual & Annual & Annual & Annual \\
\hline 699-S30-E11A & & Annual & Annual & Annual & Annual & Annual & Annual \\
\hline 699-S31-E10A & & Annual & Annual & Annual & Annual & Annual & Annual \\
\hline 699-S31-E10C & & Annual & Annual & Annual & Annual & Annual & Annual \\
\hline 699-S31-E10D & & Annual & Annual & Annual & Annual & Annual & Annual \\
\hline 699-S31-E11 & & Annual & Annual & Annual & Annual & Annual & Annual \\
\hline 699-S41-E12 & Annual & & & & & & \\
\hline
\end{tabular}


Table 5.2. List of Constituents Analyzed by EPA VOA Method 8260

1,1,1-Trichloroethane
1,1,2-Trichloroethane
1,1-Dichloroethane
1,2-Dichloroethane
1,4-Dichlorobenzene
1-Butanol
2-Butanone
4-Methyl-2-Pentanone

Acetone

Benzene

Carbon disulfide

Carbon tetrachloride

Chloroform

Ethyl cyanide

Ethylbenzene

Methylenechloride

\author{
Tetrachloroethene \\ Tetrahydrofuran \\ Toluene \\ Trichloroethene \\ Vinyl chloride \\ Xylenes (total) \\ cis-1,2-Dichloroethene \\ trans-1,2-Dichloroethene
}

Table 5.3. List of Constituents Analyzed by EPA VOA Method 8240

\author{
1,1,1-Trichloroethane \\ 1,1,2,2-Tetrachloroethane \\ 1,1,2-Trichloroethane \\ 1,1-Dichloroethane \\ 1,1-Dichloroethene \\ 1,2-Dichloroethane \\ 1,2-Dichloroethene(Total) \\ 1,2-Dichloropropane \\ 2-Butanone \\ 2-Hexanone \\ 4-Methyl-2-Pentanone
}

Acetone
Benzene
Bromodichloromethane
Bromoform
Bromomethane
Carbon disulfide
Carbon tetrachloride
Chlorobenzene
Chloroethane
Chloroform
Chloromethane

\author{
Dibromochloromethane \\ Ethylbenzene \\ Methylenechloride \\ Styrene \\ Tetrachloroethene \\ Toluene \\ Trichloroethene \\ Vinyl chloride \\ Xylenes (total) \\ cis-1,3-Dichloropropene \\ trans-1,3-Dichloropropene
}

Table 5.4. List of Constituents Analyzed by EPA VOA Method 8010

\author{
1,1,1-Trichloroethane \\ 1,1,2-Trichloroethane \\ 1,1-Dichloroethane \\ 1,2-Dichloroethane \\ 1,4-Dichlorobenzene \\ Benzene
}

\author{
Carbon tetrachloride \\ Chloroform \\ cis-1,2-Dichloroethene \\ Ethylbenzene \\ Methylenechloride \\ Tetrachloroethene
}

\author{
Toluene \\ trans-1,2-Dichloroethene \\ Trichloroethene \\ Vinyl chloride \\ Xylenes (total)
}


Table 5.5. List of Constituents Analyzed by EPA VOA Method 502.2

1,1,1-Trichloroethane

1,1-Dichloroethane

1,2-Dichloroethane

Benzene

Carbon tetrachloride
Chloroform

Ethylbenzene

Methylenechloride

Tetrachloroethene

Toluene
Trichloroethene

Xylenes (total)

cis-1,2-Dichloroethene

trans-1,2-Dichloroethene

Table 5.6. List of Constituents Analyzed by Contract Laboratory Program Volatile Organics Analysis

1,1,1-Trichloroethane

1,1,2,2-Tetrachloroethane

1,1,2-Trichloroethane

1,1-Dichloroethane

1,1-Dichloroethene

1,2-Dichloroethane

1,2-Dichloroethene(Total)

1,2-Dichloropropane

2-Butanone

2-Hexanone

4-Methyl-2-Pentanone

Acetone
Benzene

Bromodichloromethane

Bromoform

Bromomethane

Carbon disulfide

Carbon tetrachloride

Chlorobenzene

Chloroethane

Chloroform

Chloromethane

Dibromochloromethane

Ethylbenzene
Methylenechloride

Styrene

Tetrachloroethene

Toluene

Trichloroethene

Vinyl acetate

Vinyl chloride

Xylenes (total)

cis-1,3-Dichloropropene

trans-1,3-Dichloropropene 


\subsection{Trichloroethene Results}

\subsection{Soil Gas Survey}

Evidence for volatilization is supported by a soil gas survey conducted in 1989 (Evans 1989). Measurable TCE was detected in soil gas on the east side of the HRL and in a narrow area west of the central pit spreading north from the HRL's southern boundary. TCE concentrations in soil gas ranged from less than $0.01 \mu \mathrm{g} / \mathrm{L}$ (detection level) to $4.74 \mu \mathrm{g} / \mathrm{L}$ (Evans 1989). During a second stage of soil gas sampling, TCE was detected at concentrations ranging from 2 to 255 part per million by volume (ppbv) in 36 of the 53 sample locations (DOE 1992a, 1992b). In the area immediately northeast of the HRL, TCE was detected in soil gas during a soil gas survey conducted in $\sim 1994 .{ }^{1}$ However, these 1994 results were not published.

\subsection{Trichloroethene Plumes in the Top of the Unconfined Aquifer}

Trichloroethene contamination occurs beneath the HRL, offsite in AREVA wells, and in the 300 Area. This is illustrated by TCE plume maps for fiscal years (FY) 1990, 1992, 1994, 1996, 1998, early 2001, 2001 (FY average), and 2006 (Figures 6.1 through 6.8). The distribution of TCE shows that the plume beneath the HRL has had a southwest-northeast elongated configuration, occupying an area between AREVA and the southwestern corner of the 300 Area. The TCE plume configurations indicate a northeasterly flow direction toward the 300 Area. This northeasterly flow direction is consistent with the flow direction interpreted from the water-table map contours (Figure 4.1) and the nitrate plume map for the area (Figure 6.9). TCE concentration data indicate that TCE has migrated in groundwater from the area beneath AREVA and HRL to the southwestern corner of the 300 Area.

The earliest (FY 1990) distribution of TCE for which data is available near the HRL is shown in Figure 6.1. The area of the plume above the $5-\mu \mathrm{g} / \mathrm{L}$ maximum contaminant level, $\sim 0.5 \mathrm{~km}^{2}\left(0.2 \mathrm{mi}^{2}\right)$, extends from the process lagoons at AREVA to at least the northeastern edge of the HRL. The extent of the plume beyond the HRL to the northeast in FY 1990 is inferred because many of the wells downgradient of the HRL were not sampled for TCE or had not been drilled yet. A sample from one well (699-S29-E12) downgradient of the HRL showed a nondetection for TCE; however, later plume maps indicate that this well was not in the direct flow path of the TCE plume. In the 300 Area, TCE was detected just above the 5- $\mu \mathrm{g} / \mathrm{L}$ maximum contaminant level in one well. During FY 1990, many of the wells in the 300 Area were either not sampled for TCE or the TCE measurement was below the minimum detection limit for those that were sampled. The $5-\mu \mathrm{g} / \mathrm{L}$ contour in Figure 6.1 is interpreted using both FY 1990 and 1992 data.

In FY 1992, most of the monitoring wells in and around the HRL and the 300 Area were sampled for TCE. Unlike earlier analyses, these samples were analyzed at minimum detection limits $<5 \mu \mathrm{g} / \mathrm{L}$ (Figure 6.2). Figure 6.2 shows two distinct, unrelated TCE plumes existed in the top of the unconfined aquifer; one was beneath the HRL and AREVA and one was in the central to southeastern part of the 300 Area. Near the HRL, the FY 1992 plume generally occupied the same area as in FY 1990, but the

\footnotetext{
${ }^{1}$ Personal communication between the author and PNNL staff.
} 
plume area at higher concentrations ( $>50 \mu \mathrm{g} / \mathrm{L}$ ) decreased significantly because these higher concentrations were detected in only one well. The TCE plume in the 300 Area appears to be related to a source in the 300 Area (DOE 1993). This is supported by TCE levels not detected (i.e., $<1 \mu \mathrm{g} / \mathrm{L}$ ) in wells between the two plumes (i.e., near the southwestern corner of the 300 Area and adjacent to Stevens Drive).

By FY 1994, the TCE plume migrated farther downgradient of the HRL to the northeast and stretched from the lagoons at AREVA to just west of Stevens Drive (Figure 6.3). The area of the TCE plume in FY 1994 was $\sim 0.7 \mathrm{~km}^{2}\left(0.3 \mathrm{mi}^{2}\right)$, the greatest size it reached at concentration levels exceeding $5 \mu \mathrm{g} / \mathrm{L}$ TCE continued to be elevated above the MCL in the unrelated plume in the southeastern part of the 300 Area in FY 1994.

After FY 1994, the TCE plume continued to migrate to the northeast toward the southwestern corner of the 300 Area and began to diminish in size (Figures 6.4 and 6.5). The area of the plume decreased from $\sim 0.7 \mathrm{~km}^{2}\left(0.3 \mathrm{mi}^{2}\right)$ in FY 1994 to slightly above $0.5 \mathrm{~km}^{2}\left(0.2 \mathrm{mi}^{2}\right)$ in FY 1998. By FY 1998, the TCE plume occupied an area extending from the northeastern part of the HRL to Stevens Drive just southwest of the 300 Area, or 1,200 m (3,900 ft) northeast of the HRL (see Figure 6.5). This is the greatest distance that the TCE plume reached downgradient of the HRL at the 5- $\mu \mathrm{g} / \mathrm{L}$ level. The small, unrelated TCE plume in the southeastern part of the 300 Area diminished to levels below the maximum contaminant level by FY 1996 (Figure 6.4).

The TCE plume decreased significantly in areal size between FY 1998 and early FY 2001 (Figures 6.5 and 6.6). In early FY 2001, the TCE plume at levels $>5 \mu \mathrm{g} / \mathrm{L}$ occupied a small area of $\sim 0.05 \mathrm{~km}^{2}\left(0.02 \mathrm{mi}^{2}\right)$ just northeast of the HRL. TCE data are not available for FY 2000 because the sampling was delayed to early FY 2001, a result of issues associated with sample-related waste on the Hanford Site.

By the middle of FY 2001 (April/May 2001), TCE concentrations had decreased to levels $<5 \mu \mathrm{g} / \mathrm{L}$ in all groundwater monitoring wells in the HRL area. The TCE concentrations in Figure 6.7 represent an average of the early FY 2001 and middle FY 2001 data. Fiscal year 2001 is the first year (since TCE was first detected) that average TCE concentrations were less than the $5-\mu \mathrm{g} / \mathrm{L} \mathrm{MCL}$ in all monitoring wells near the HRL area.

After FY 2001, the TCE concentrations continued to decrease. The FY 2006 plume, as defined by the $1-\mu \mathrm{g} / \mathrm{L}$ concentration contour, is shown in Figure 6.8. The plume is shown as merged with the 300 Area plume. The TCE plume map for FY 2006 indicates that TCE continues to be detected, but at levels less than the 5- $\mu \mathrm{g} / \mathrm{L}$ MCL. The TCE plume at these low concentrations extends from AREVA and the HRL northeast to the 300 Area and the Columbia River.

\subsection{Trichloroethene Trends in the Top of the Unconfined Aquifer}

Concentrations have decreased in essentially all the plume areas near the HRL. TCE concentrations decreased by nearly two orders of magnitude since monitoring began in early 1990 following well installations in this area. The decrease is illustrated in Figure 6.10 by two wells adjacent to the HRL. On the Hanford Site, concentrations in well 699-S31-E10A decreased from a maximum average of $104 \mu \mathrm{g} / \mathrm{L}$ in 1990 to $1.4 \mu \mathrm{g} / \mathrm{L}$ in 2006. A similar trend at slightly lower TCE concentrations is shown for well 
699-S31-E10D. The trend of the concentrations in Figure 6.10 indicates that TCE may have arrived at its maximum concentration at the wells prior to 1990. A higher TCE concentration was detected prior to 1990 in a well at the AREVA facility, which is upgradient of well 699-S31-E10A and the HRL (DOE 1992a, 1992b).

Figure 6.11 shows TCE trends in five wells located between the HRL and the point of compliance. Groundwater sample results indicate that concentrations exceeded the 5- $\mu \mathrm{g} / \mathrm{L}$ MCL for TCE in three of these wells (699-S29-E11, 699-S29-E12, and 699-S30-E11A). The trends indicate that TCE concentrations in wells in this area decreased to levels below the MCL by 1999.

The arrival and attenuation of the TCE contaminant pulse downgradient from the source area can be used to differentiate between the plume at the HRL and a separate, unrelated plume in the 300 Area. This is illustrated by trend plots for detectable levels of TCE in Figure 6.12. TCE arrived in well 699-S29-E11 (located $\sim 1,250 \mathrm{~m}[4,100 \mathrm{ft}]$ downgradient from the assumed source area) in the early 1990s, reached a maximum concentration in late 1994, and then attenuated thereafter. TCE concentrations began to increase in well 699-S28-E12 (located 1,800 m [5,900 ft] downgradient from the assumed source area) in the mid-1990s, peaked in 1998, and then decreased after 1998. The contaminant pulses in these two wells represent the TCE plume passing through these wells. Farther downgradient in the 300 Area, TCE concentrations arrived in well 399-4-1 prior to 1985 and decreased since it was sampled in 1985 and 1986, long before TCE had arrived in the wells 699-S29-E11 and 699-S28-E12. The TCE pulse observed in well 399-4-1 cannot be related to the pulses observed in the two wells upgradient of well 399-4-1. The TCE pulse passing through well 399-4-1 has a separate and distinct source area unrelated to the TCE plume in the HRL area. No Hanford Site TCE data exists prior to 1985 for the HRL area and the 300 Area.

Groundwater monitoring has indicated that the leading edge of the plume migrated northeast past the point of compliance (see Figures 6.4 and 6.5). TCE concentration trends at the point of compliance are shown in Figure 6.13. Groundwater sample results indicate that concentrations exceeded the 5- $\mu \mathrm{g} / \mathrm{L}$ MCL for TCE in two of the point-of-compliance monitoring wells (699-S27-E12A and 699-S28-E12). Concentrations exceeded the standard in 1996 (one sampling event) and 1998. After 1998, TCE concentrations at the point of compliance decreased to levels less than the MCL.

\subsection{Trichloroethene in Deep Portions of the Unconfined Aquifer}

The location of limited available monitoring wells in the deep portion of the unconfined aquifer is shown in Figure 6.14. The distribution of TCE in the deep portion of the unconfined aquifer is shown in Figure 6.15. TCE was detected above the maximum contaminant level in the deep portion of the unconfined aquifer in one well (699-S31-E10C) immediately downgradient of the HRL. This location is within the area of the TCE plume in the top of the unconfined aquifer discussed above. A trend plot for this well indicates that TCE concentrations decreased to a level below the maximum contaminant level between 1991 and 2001 (Figure 6.16). These concentrations indicate that TCE in the deep portion of the unconfined aquifer downgradient of the source area is in a dissolved state, as discussed below.

TCE concentrations decreasing over time suggests that a continuing source of TCE is not present in the aquifer. If the source of the TCE were a dense, non-aqueous phase liquid (DNAPL) present in the aquifer, then TCE concentrations in the dissolved phase would be expected to be much higher and would not be expected to decrease. If a DNAPL exists, then the contaminant plume would be expected to show 
a concentration gradient with depth in the aquifer, becoming more concentrated at the base. Trichloroethene concentrations in the top of the unconfined aquifer (Figure 6.10) and the deep portion of the unconfined aquifer show nearly overlapping trends, indicating no concentration gradient. Trichloroethene concentrations were initially detected at levels of 50 to $80 \mu \mathrm{g} / \mathrm{L}$ and then decreased to levels less than the $5-\mu \mathrm{g} / \mathrm{L}$ MCL in the deep portion of the unconfined aquifer (see Figure 6.16). This pattern indicates that the TCE source exists as an aqueous phase that has dispersed vertically as well as horizontally over time.

\subsection{Trichloroethene Below the Silt Aquitard}

Wells near the HRL monitor the middle Ringold Formation below the silt aquitard. The wells are located in Figure 6.17. The distribution of TCE in the confined aquifer is shown in Figure 6.18. The trend plot for one well (699-S31-E10E) within the boundary of the TCE plume in the unconfined aquifer shows that TCE was essentially not detected below the silt aquitard (Figure 6.19). TCE was also not detected below the aquitard just west of the HRL (well 699-S32-E8). 


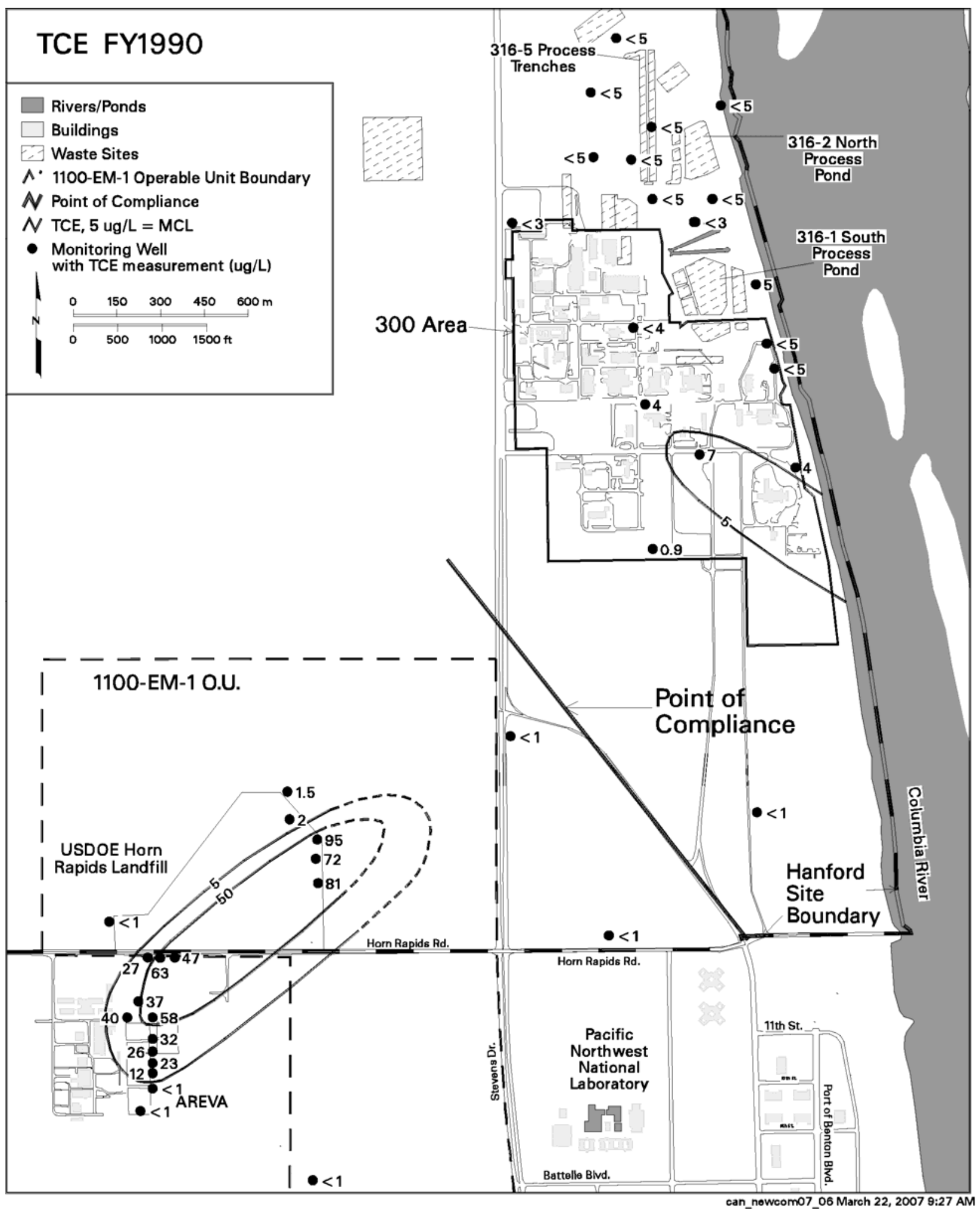

Figure 6.1. Average Trichloroethene Concentrations in the Top of the Unconfined Aquifer, FY 1990 


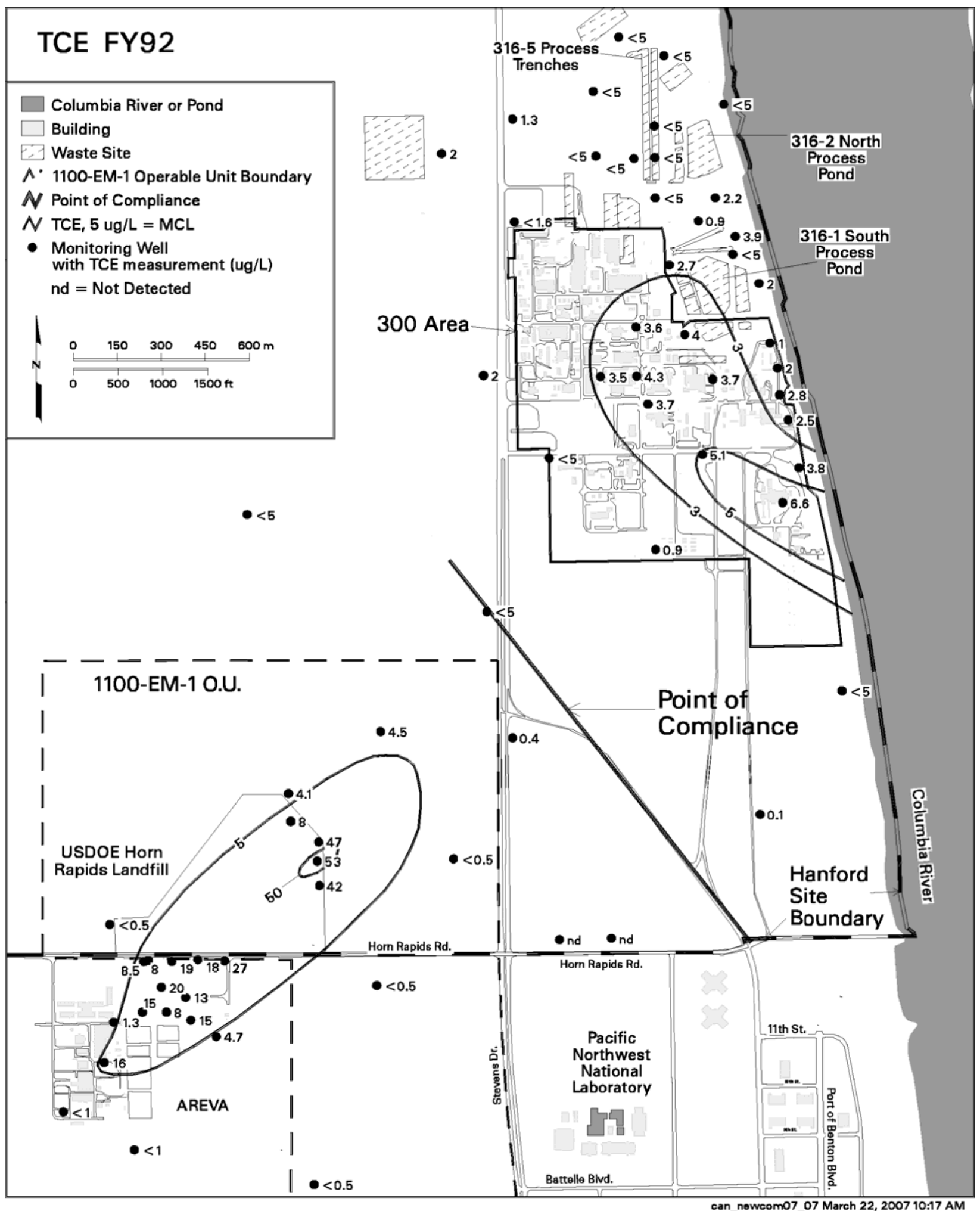

Figure 6.2. Average Trichloroethene Concentrations in the Top of the Unconfined Aquifer, FY 1992 


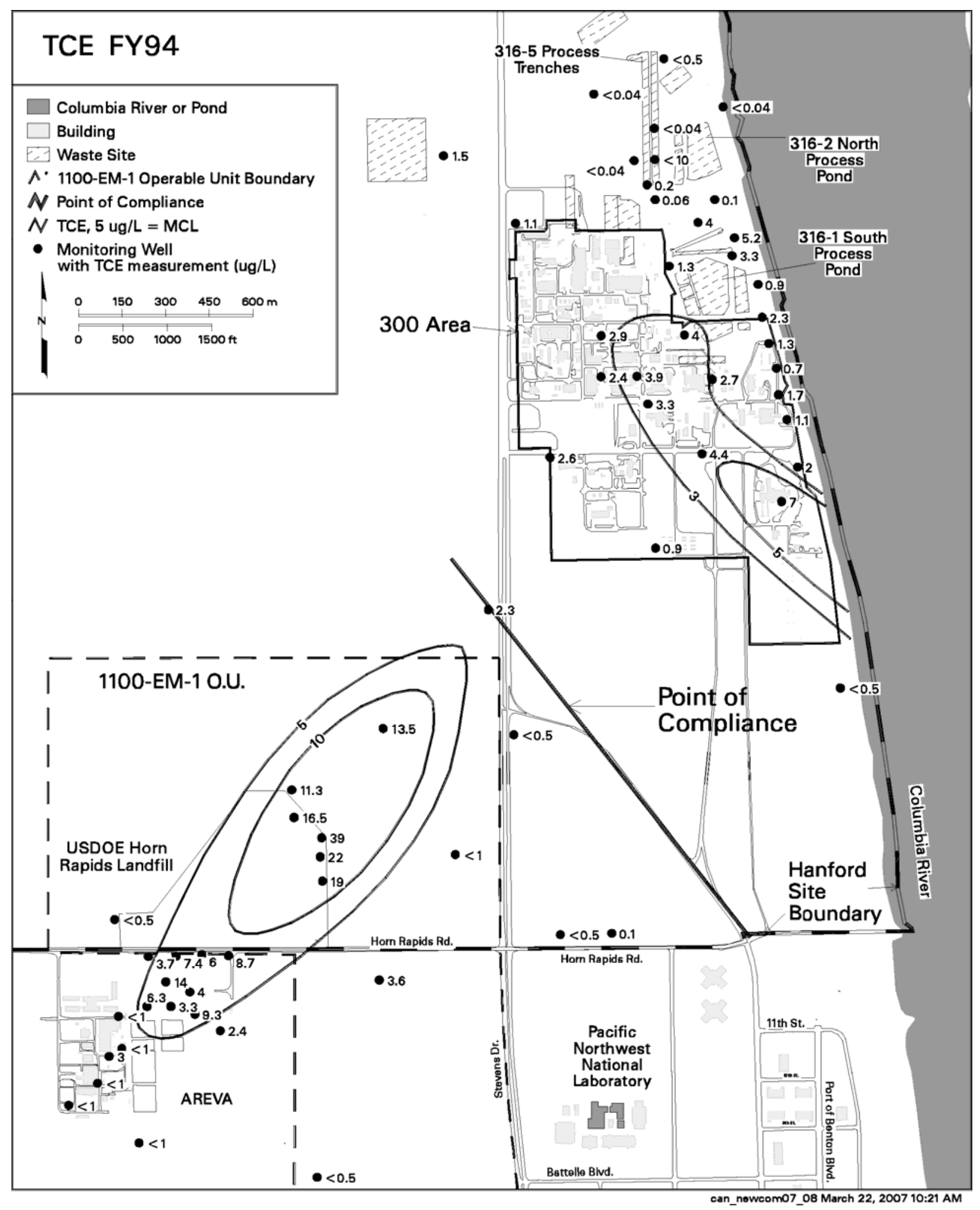

Figure 6.3. Average Trichloroethene Concentrations in the Top of the Unconfined Aquifer, FY 1994 (adapted from Dresel et al. 1995) 


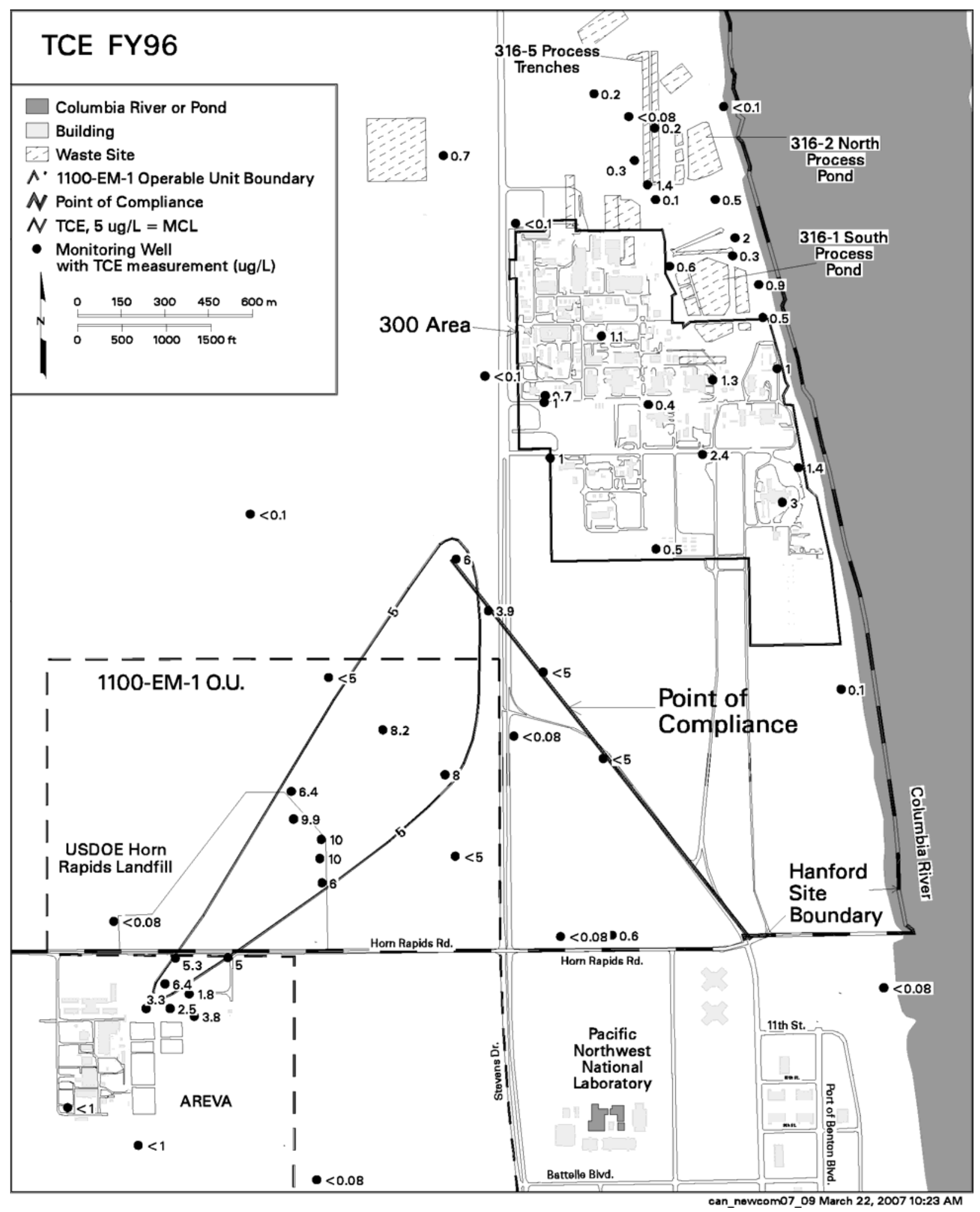

Figure 6.4. Average Trichloroethene Concentrations in the Top of the Unconfined Aquifer, FY 1996 (adapted from Hartman and Dresel 1997) 


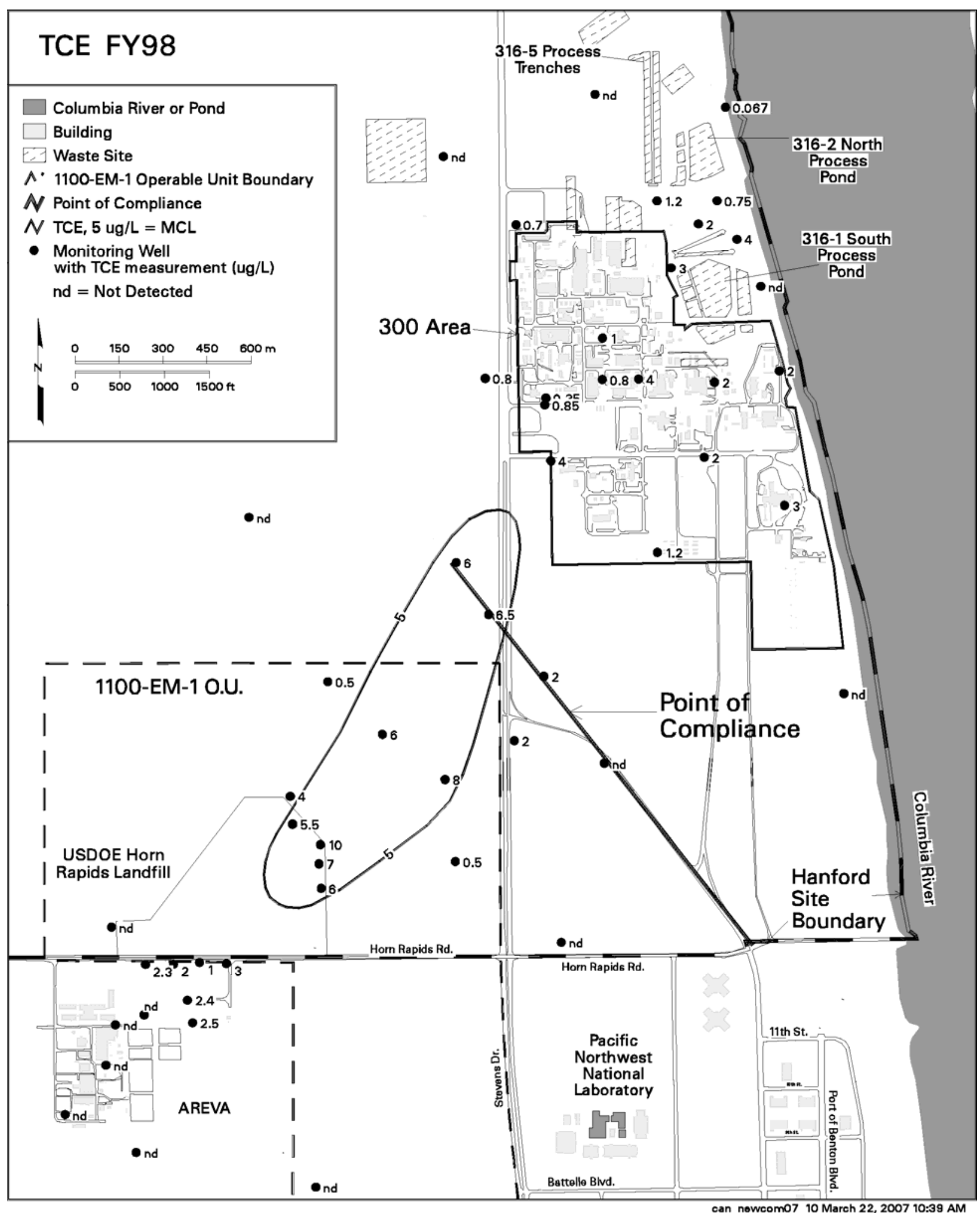

Figure 6.5. Average Trichloroethene Concentrations in the Top of the Unconfined Aquifer, FY 1998 (adapted from Hartman 1999) 


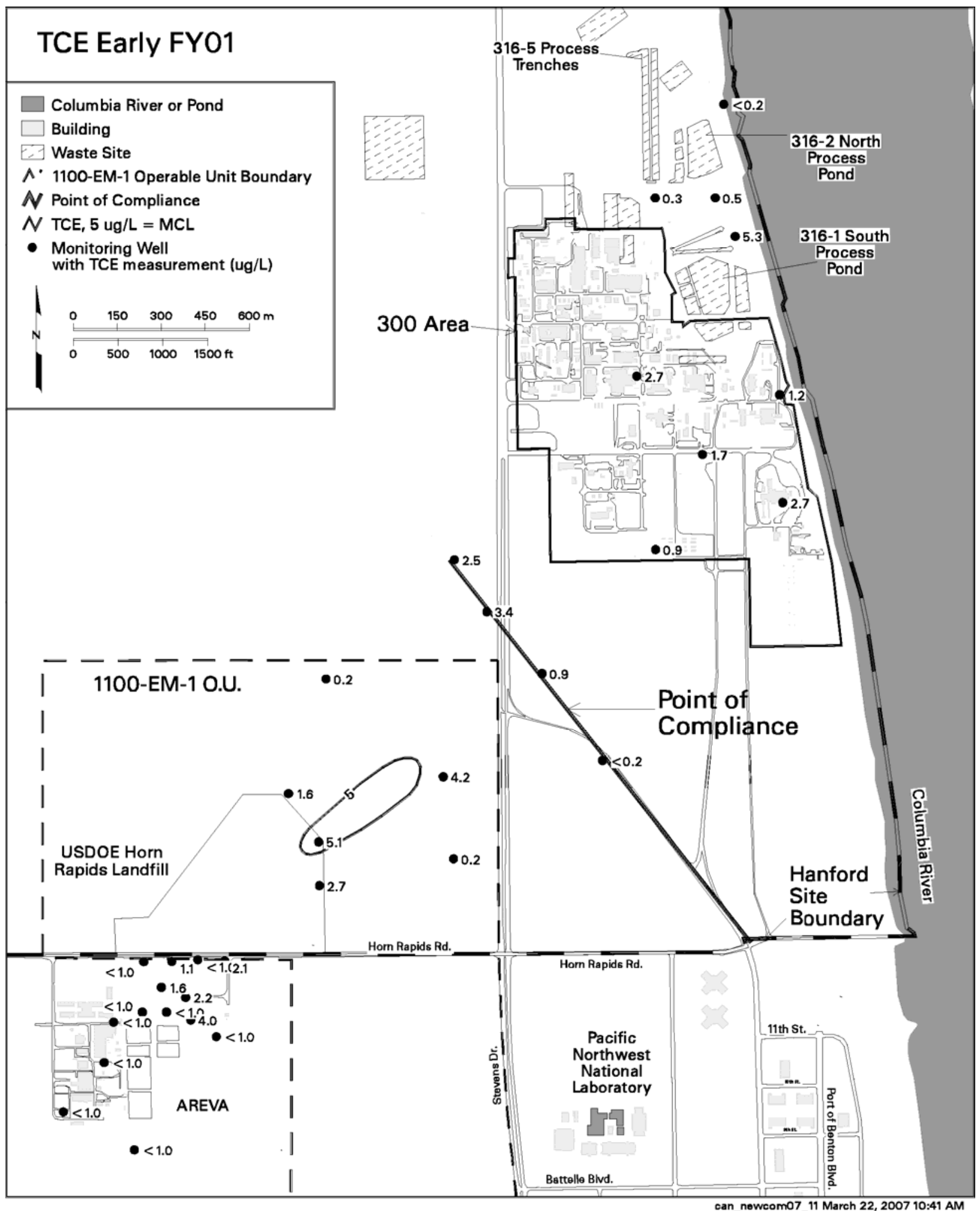

Figure 6.6. Average Trichloroethene Concentrations in the Top of the Unconfined Aquifer, Early FY 2001 


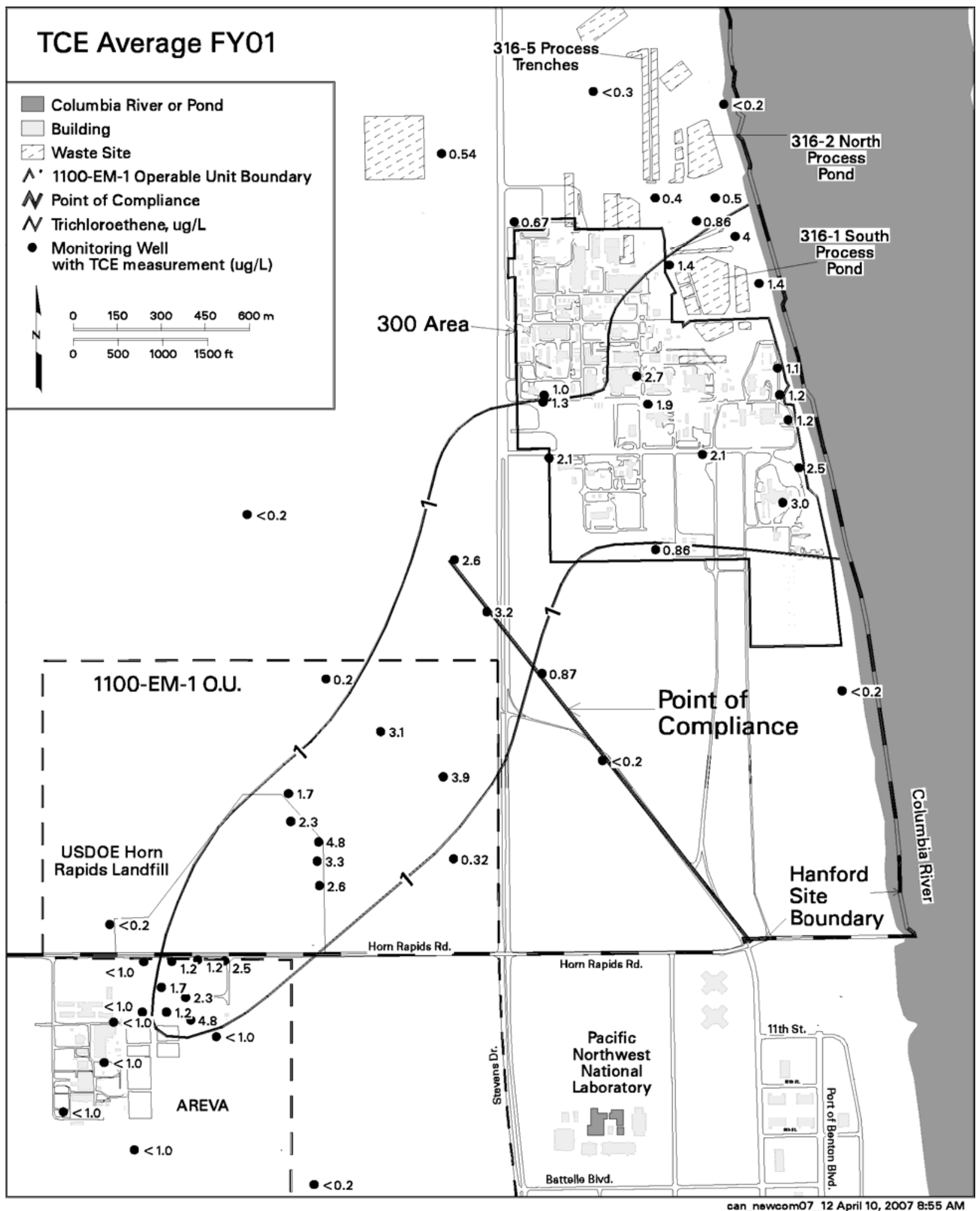

Figure 6.7. Average Trichloroethene Concentrations in the Top of the Unconfined Aquifer, FY 2001 


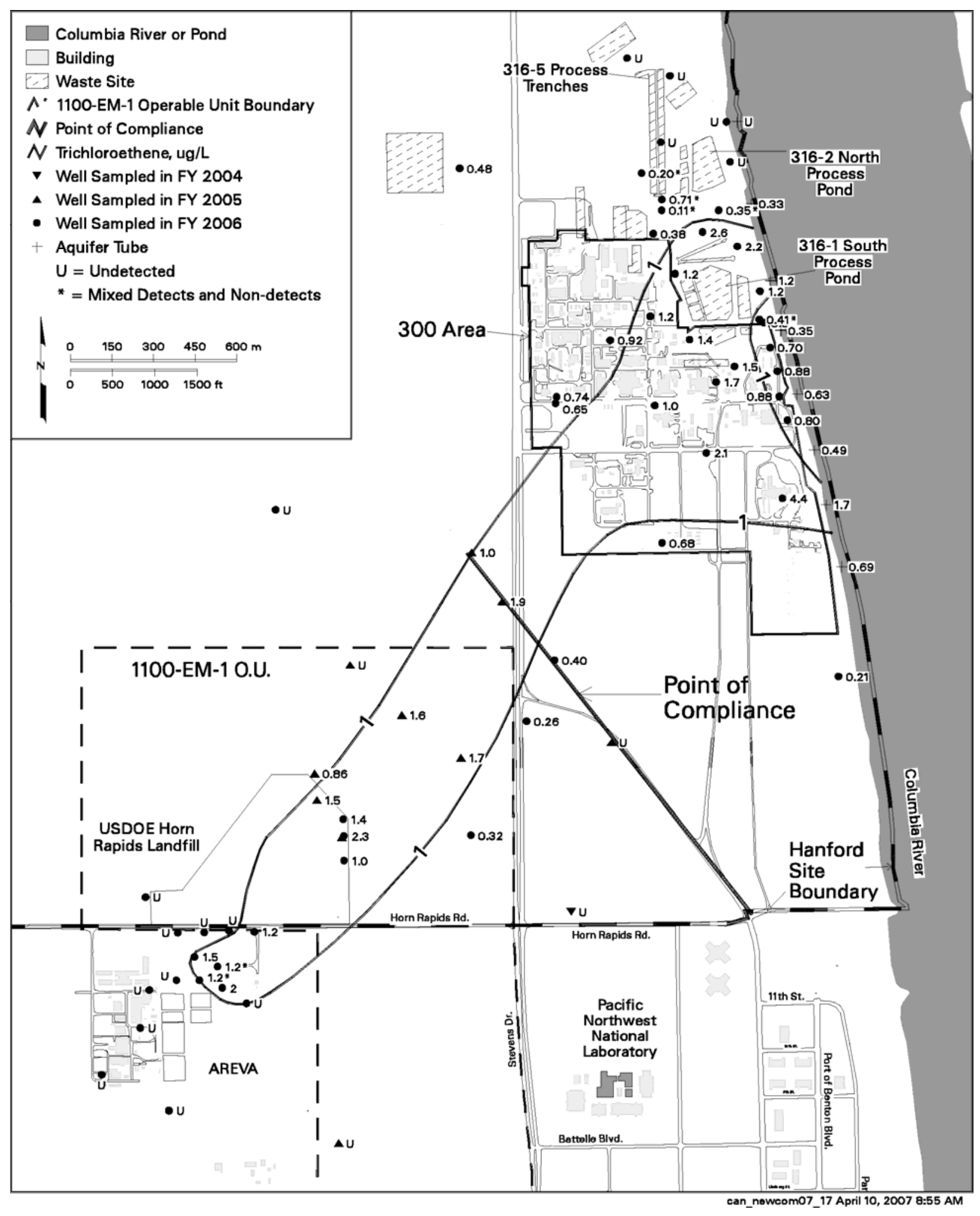

Figure 6.8. Average Trichloroethene Concentrations in the Top of the Unconfined Aquifer, FY 2006 


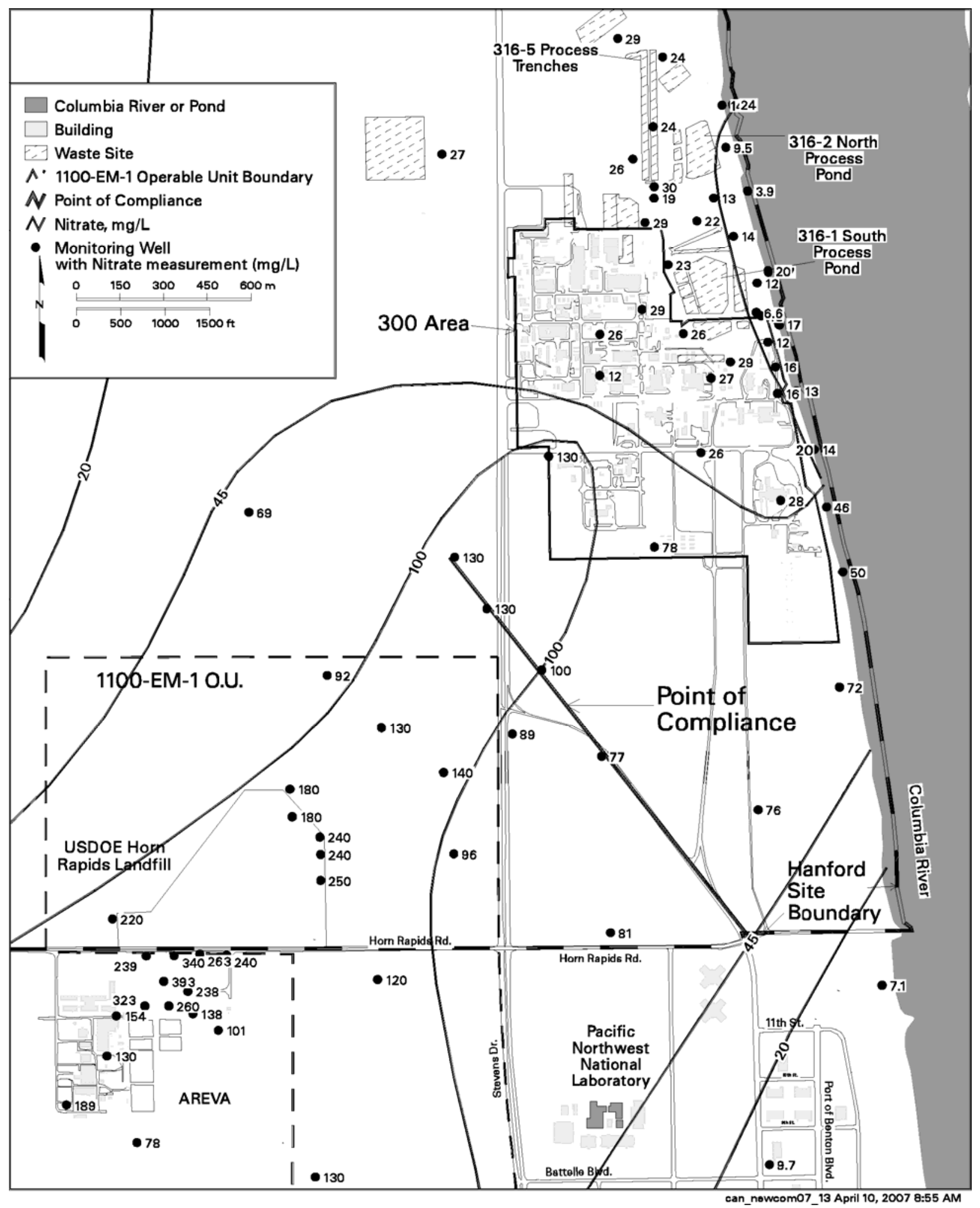

Figure 6.9. Average Nitrate Concentrations in the Top of the Unconfined Aquifer, FY 2006 (adapted from Hartman et al. 2007) 


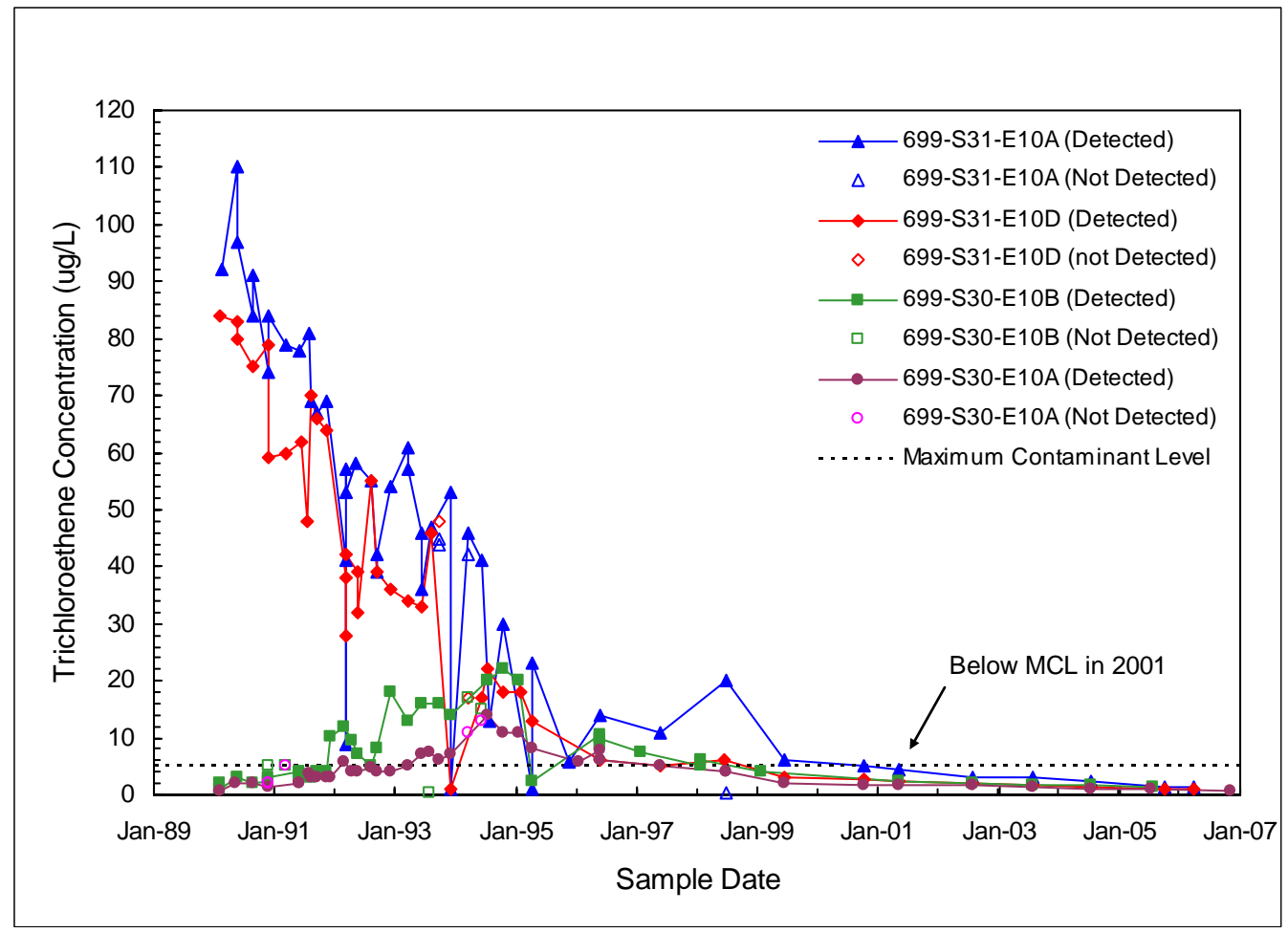

Figure 6.10. Trichloroethene Concentration Trends Adjacent to the Horn Rapids Landfill

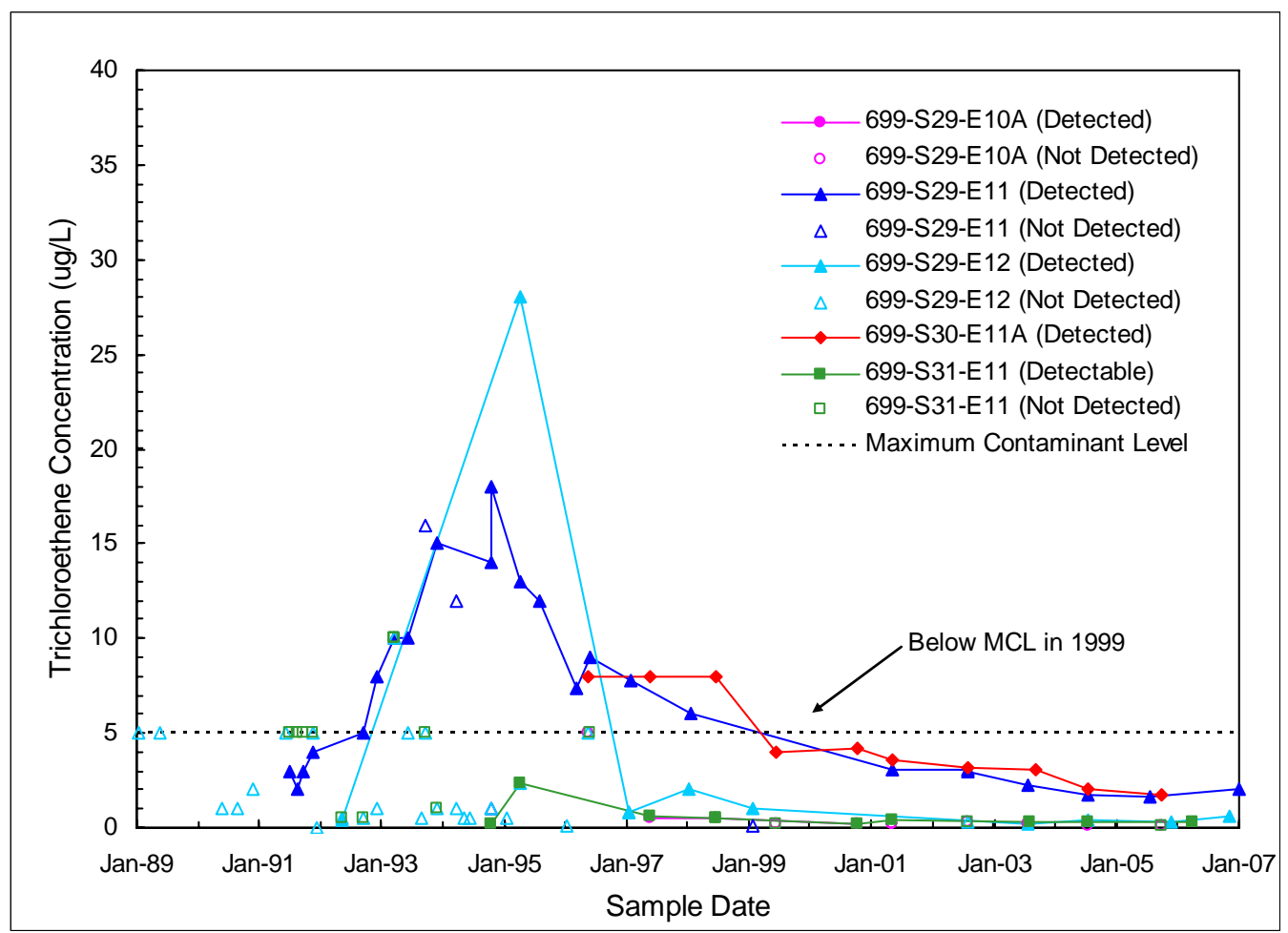

Figure 6.11. Trichloroethene Concentration Trends Between the Horn Rapids Landfill and the Point of Compliance 


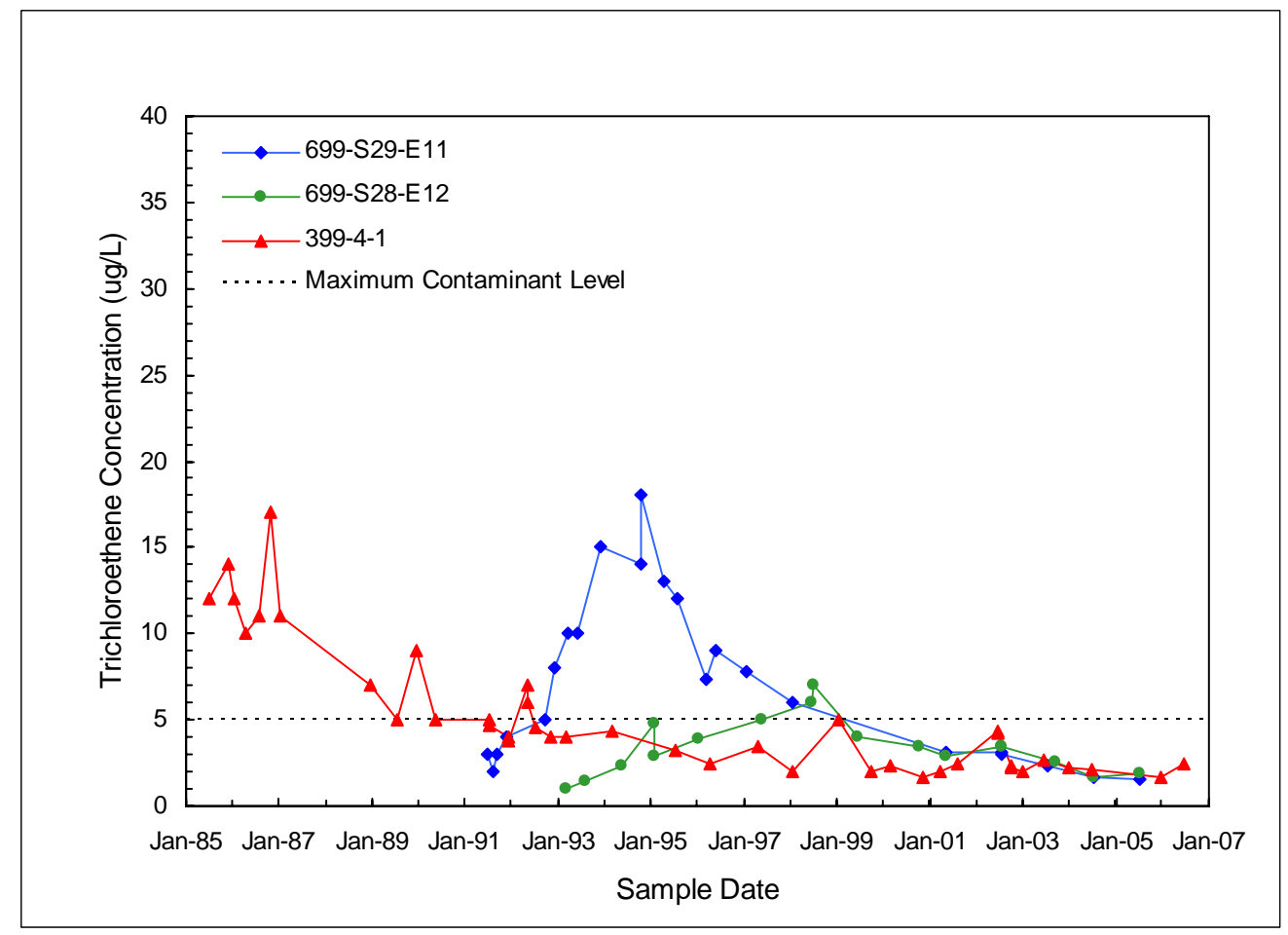

Figure 6.12. Trichloroethene Trends Northeast of the Horn Rapids Landfill

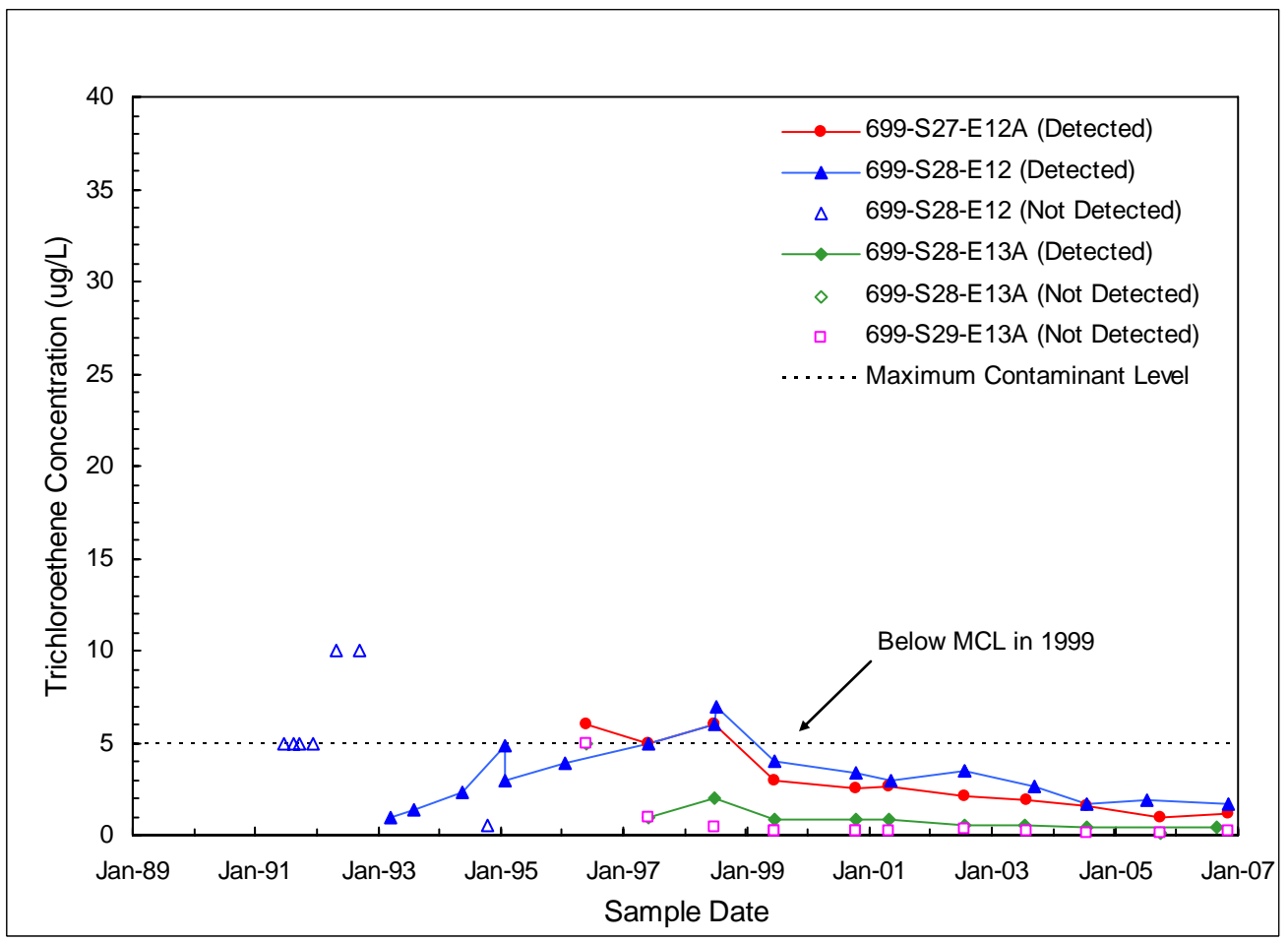

Figure 6.13. Trichloroethene Trends at the Point of Compliance 


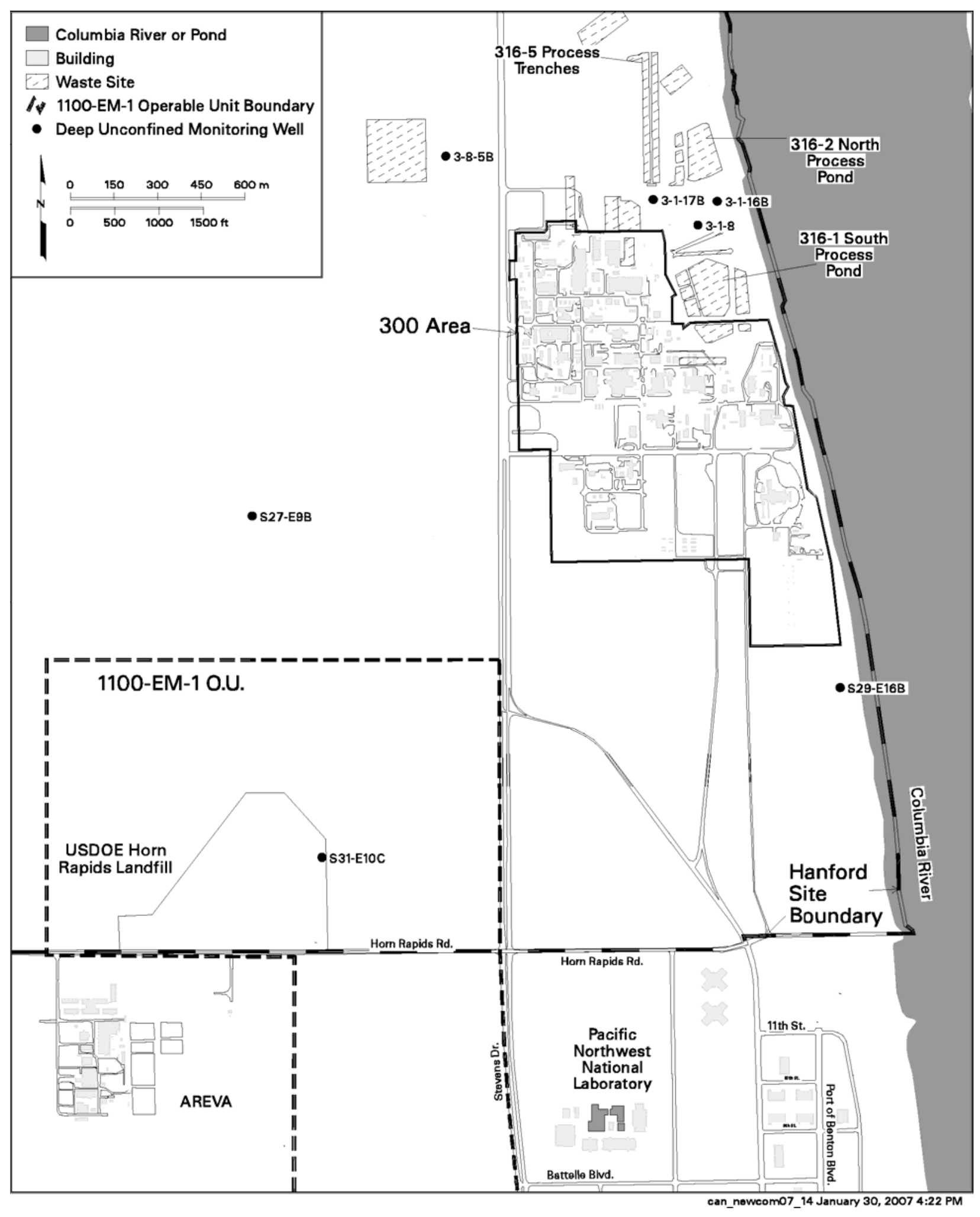

Figure 6.14. Monitoring Wells in the Deep Portion of the Unconfined Aquifer 


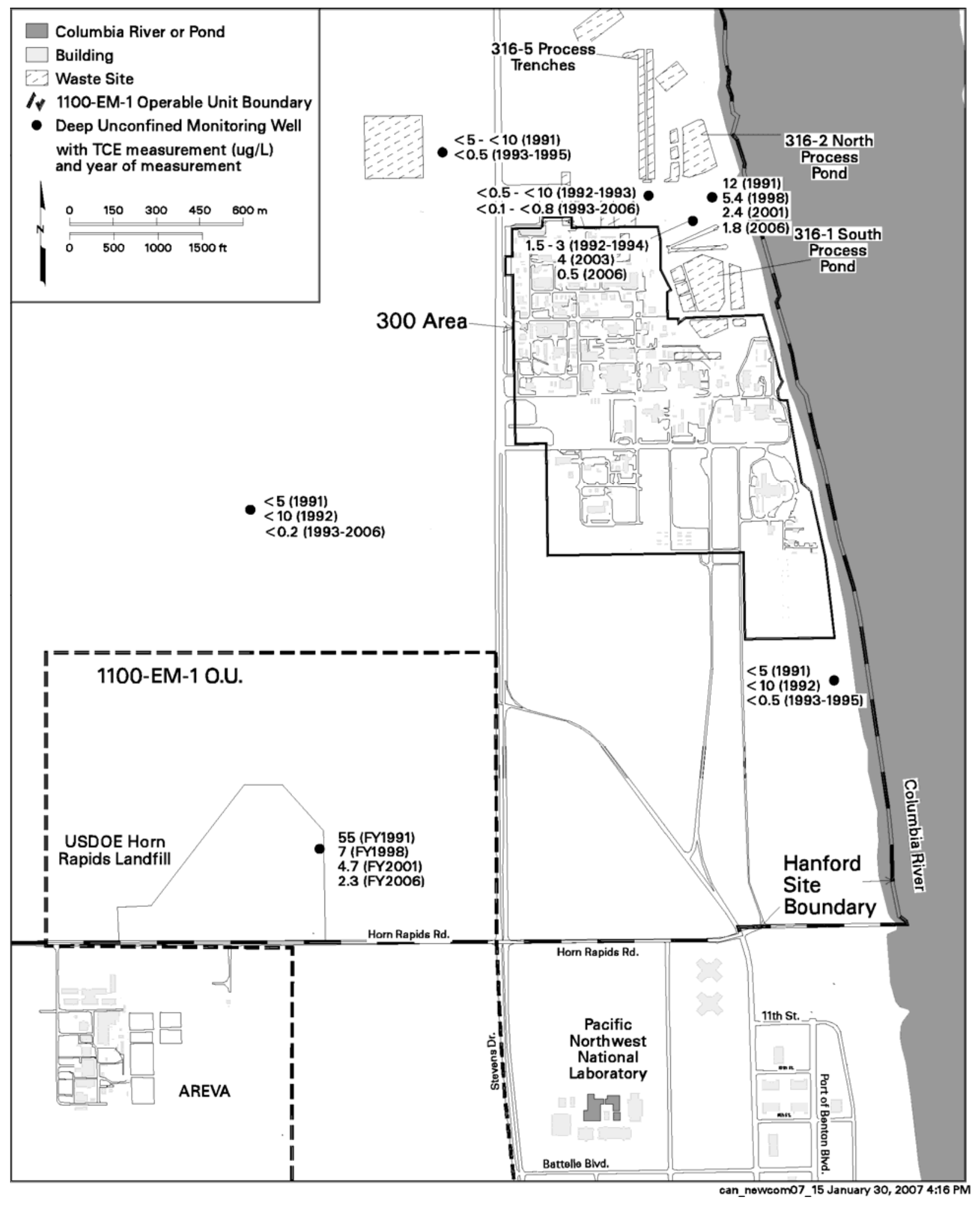

Figure 6.15. Trichloroethene Distribution in the Deep Portion of the Unconfined Aquifer 


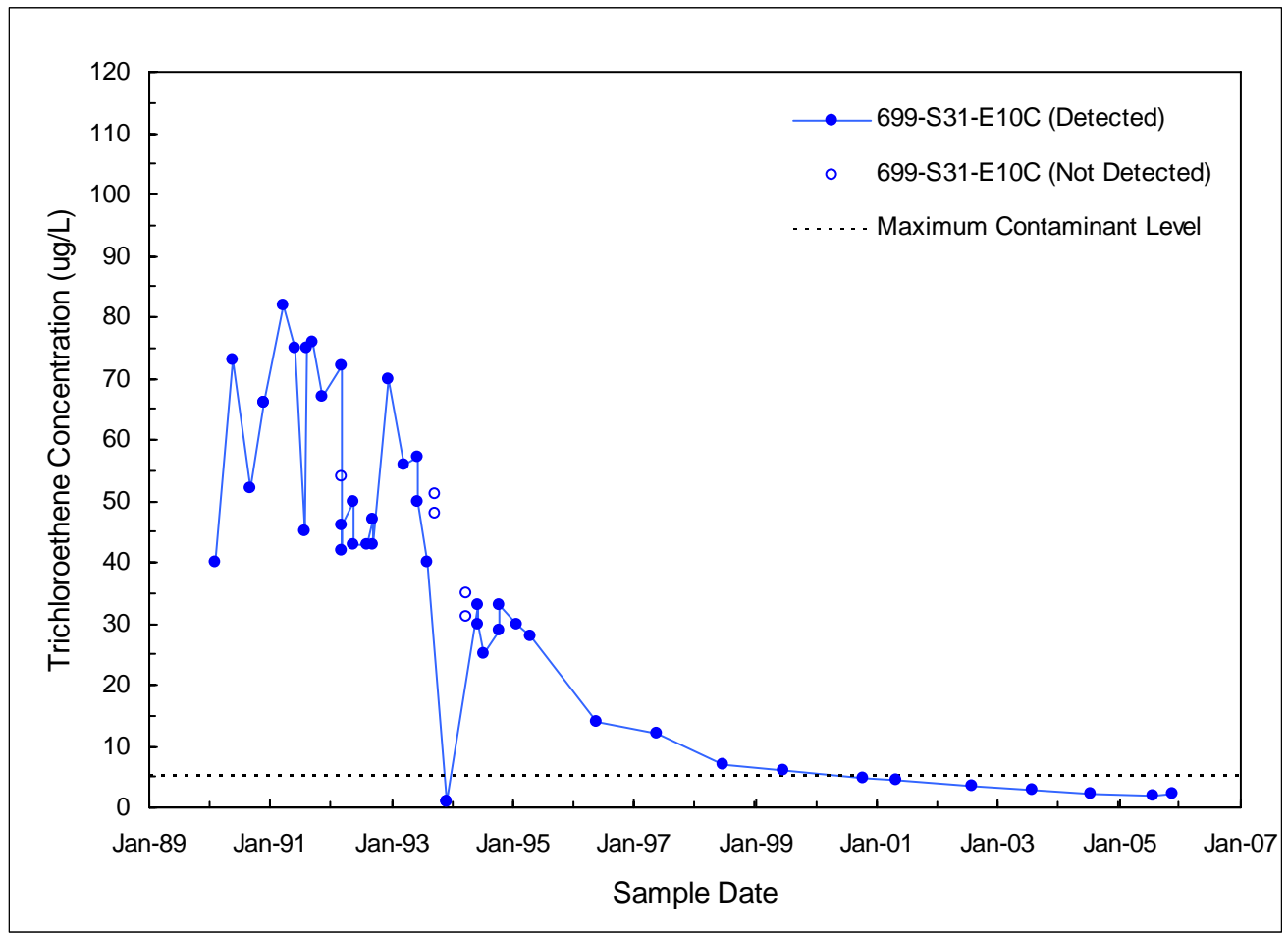

Figure 6.16. Trichloroethene Trend in the Deep Portion of the Unconfined Aquifer 


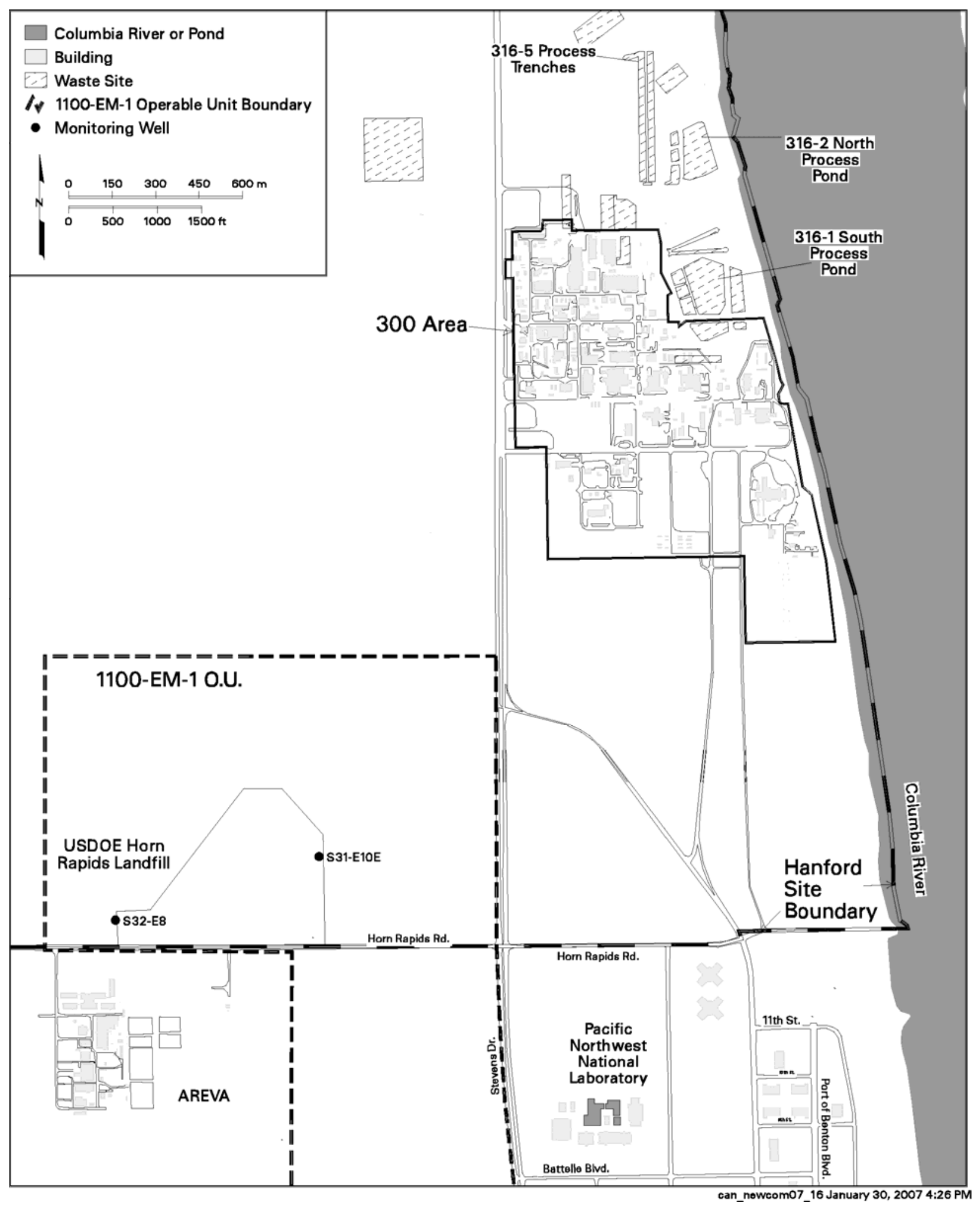

Figure 6.17. Monitoring Wells in the Confined Aquifer 


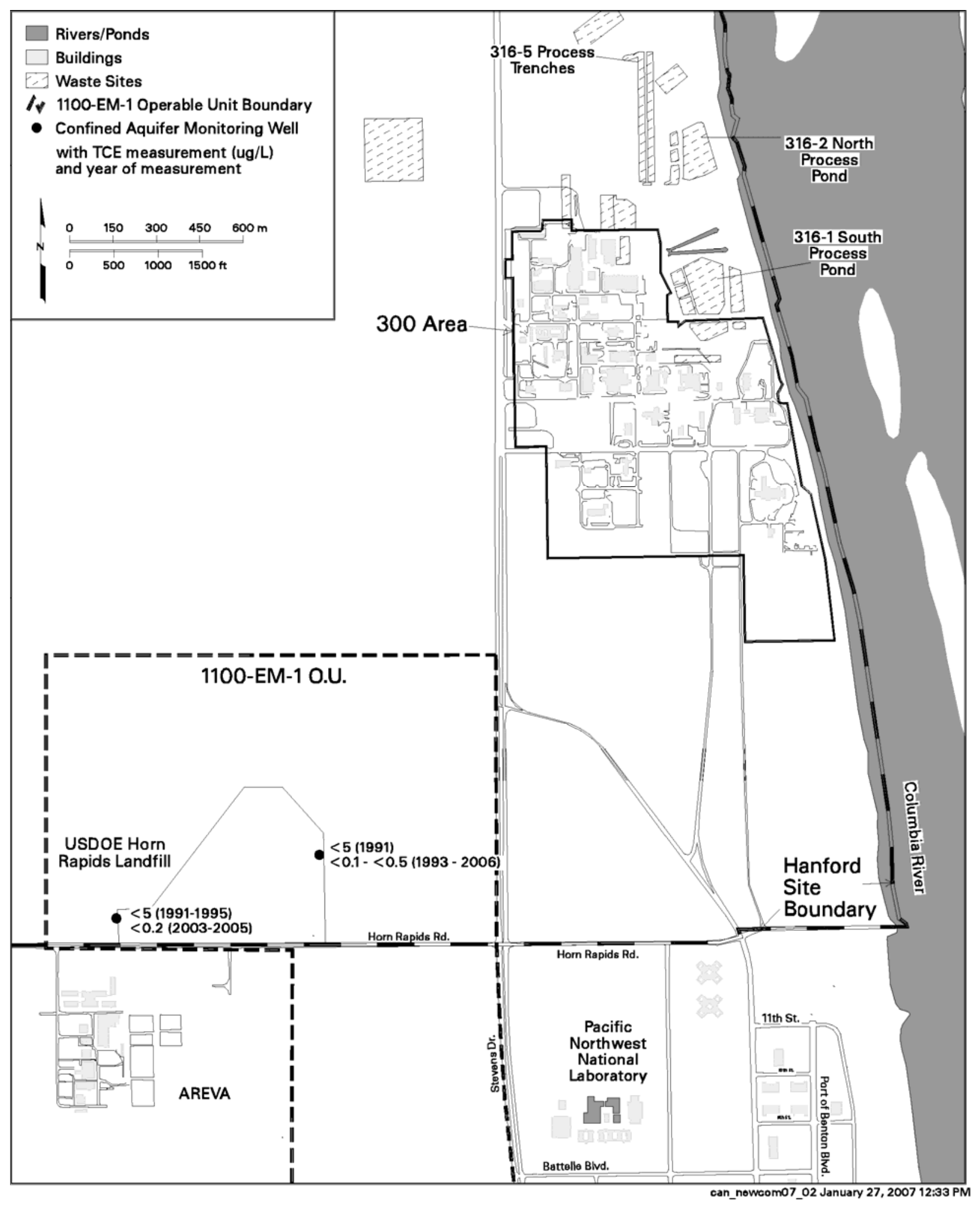

Figure 6.18. Trichloroethene Distribution in the Confined Aquifer 


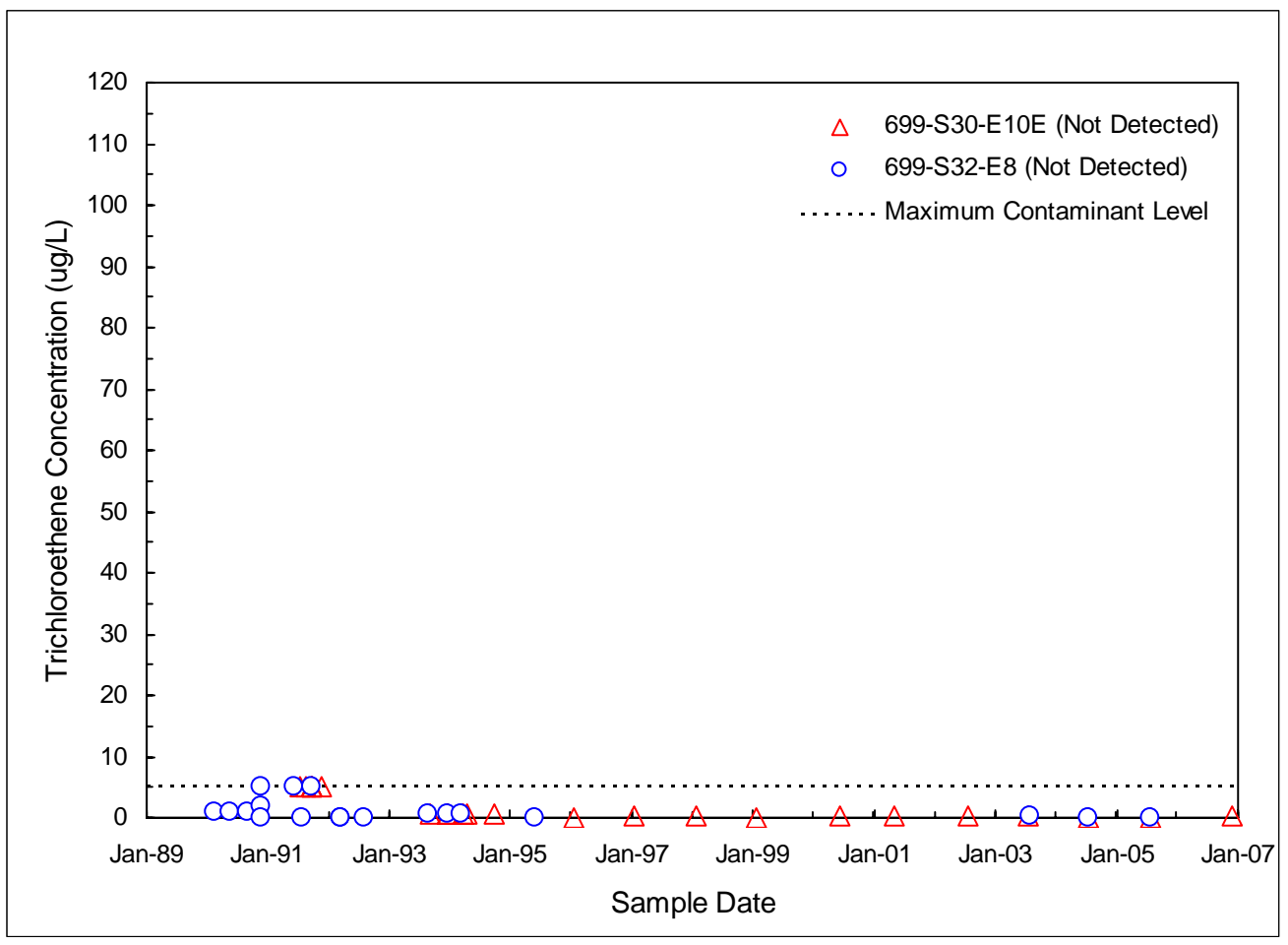

Figure 6.19. Trichloroethene Trends in the Confined Aquifer 


\subsection{Trichloroethene Degradation Product Results}

The results indicate that potential breakdown products of TCE have not been detected in any USDOE samples collected from the 1100-EM-1 Operable Unit or groundwater surveillance monitoring wells near the HRL. Plots showing the distribution of TCE breakdown products 1,1-dichloroethene, cis-1,2dichloroethene, trans-1,2-dichloroethene, and vinyl chloride over time are illustrated in Figures 7.1 through 7.4, respectively. These samples represent the upper part of the unconfined aquifer adjacent to the eastern edge of the HRL. Northeast of (downgradient of) the HRL, breakdown products were not detected at the point of compliance (Figures 7.5 through 7.8). Figures 7.9 through 7.12 show the concentrations of these breakdown products over time in the deep portion of the unconfined aquifer and Figures 7.13 through 7.16 show concentrations over time below the silt aquitard.

Quality control information indicates that detection of vinyl chloride ( 0.2 and $0.3 \mu \mathrm{g} / \mathrm{L}$; not shown in figures) in three 1999 samples are associated with contamination of lab blanks. Low concentrations of volatile organic compounds in several 1993 and 1995 samples (not shown in figures) analyzed by Method 8260 are suspect and most likely associated with reporting errors. ${ }^{2}$ The table of results in the Appendix provides data qualifier flags with these results.

\footnotetext{
${ }^{2}$ Personal communication between the author and PNNL staff.
} 


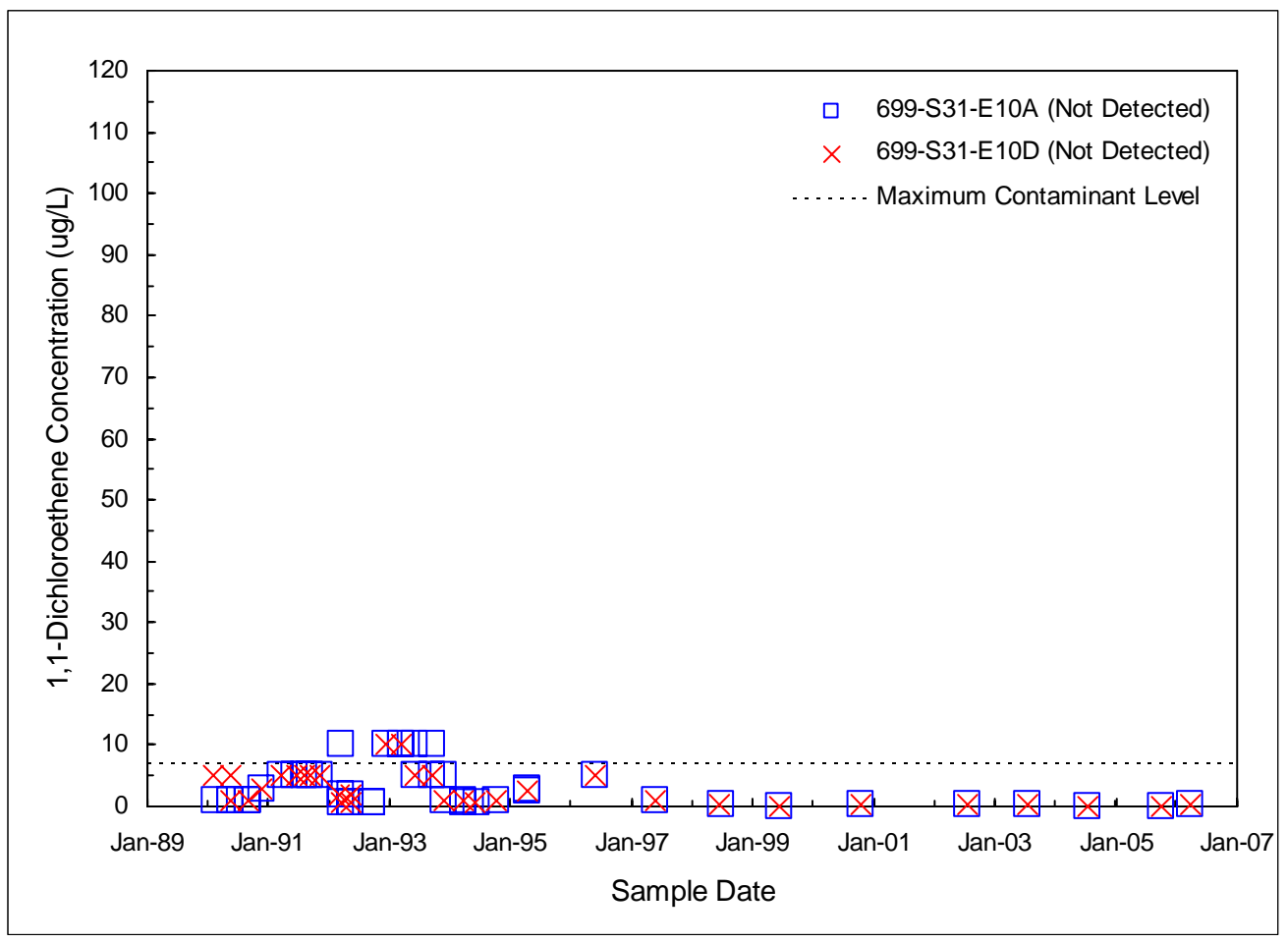

Figure 7.1. 1,1-Dichloroethene Concentrations Adjacent to the Horn Rapids Landfill

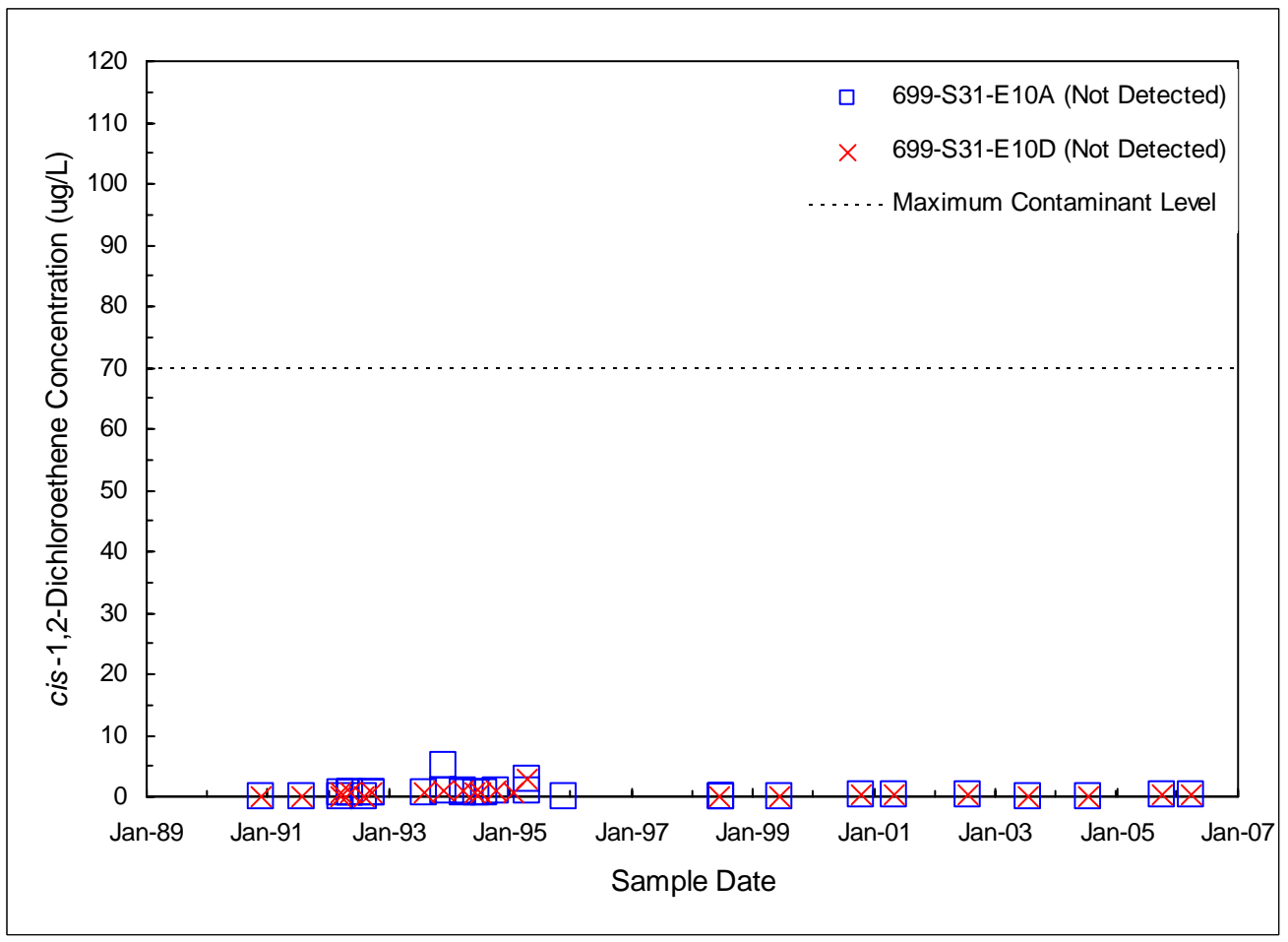

Figure 7.2. cis-1,2-Dichloroethene Concentrations Adjacent to the Horn Rapids Landfill 


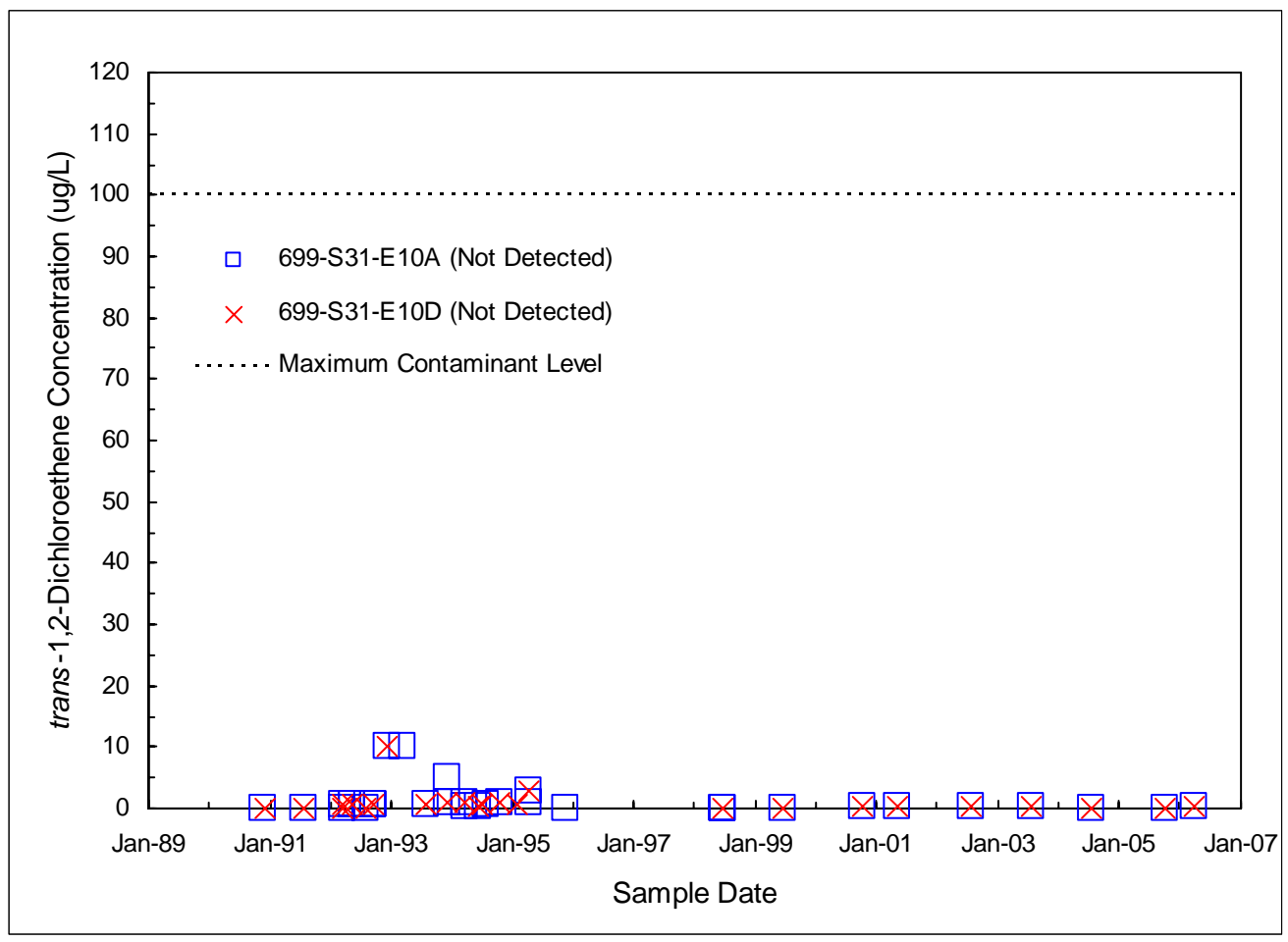

Figure 7.3. trans-1,2-Dichloroethene Concentrations Adjacent to the Horn Rapids Landfill

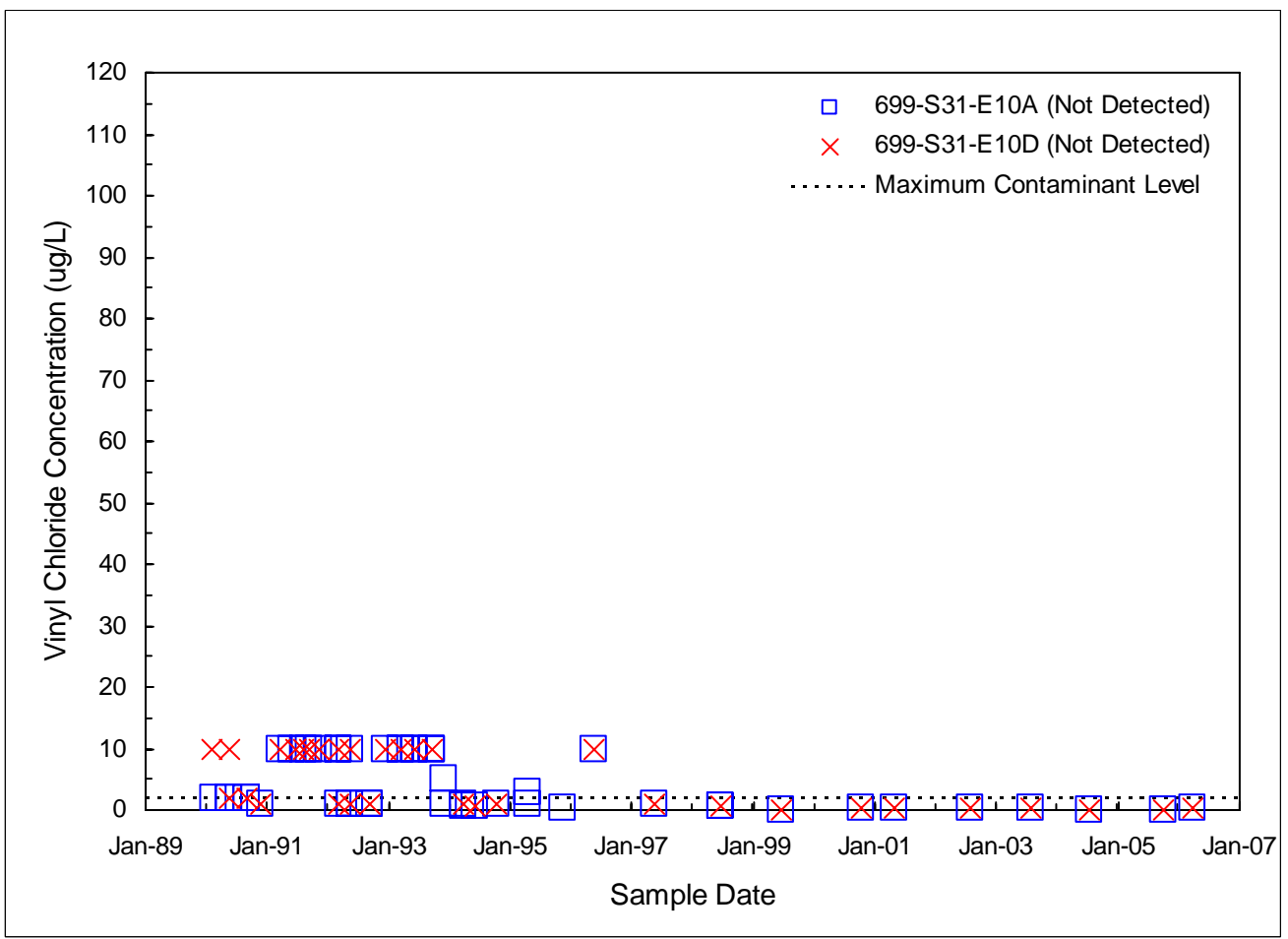

Figure 7.4. Vinyl Chloride Concentrations Adjacent to the Horn Rapids Landfill 


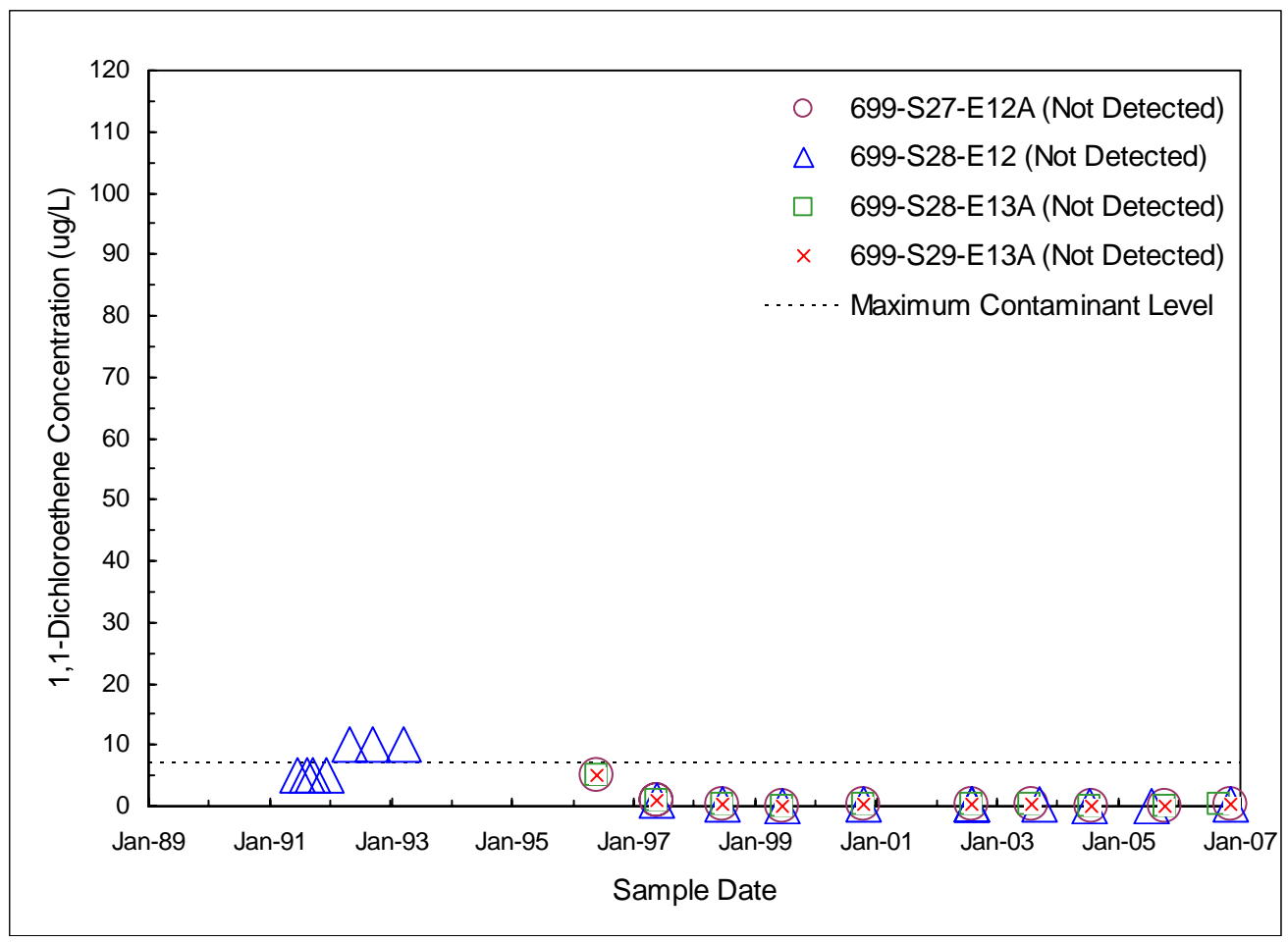

Figure 7.5. 1,1-Dichloroethene Concentrations at the Point of Compliance

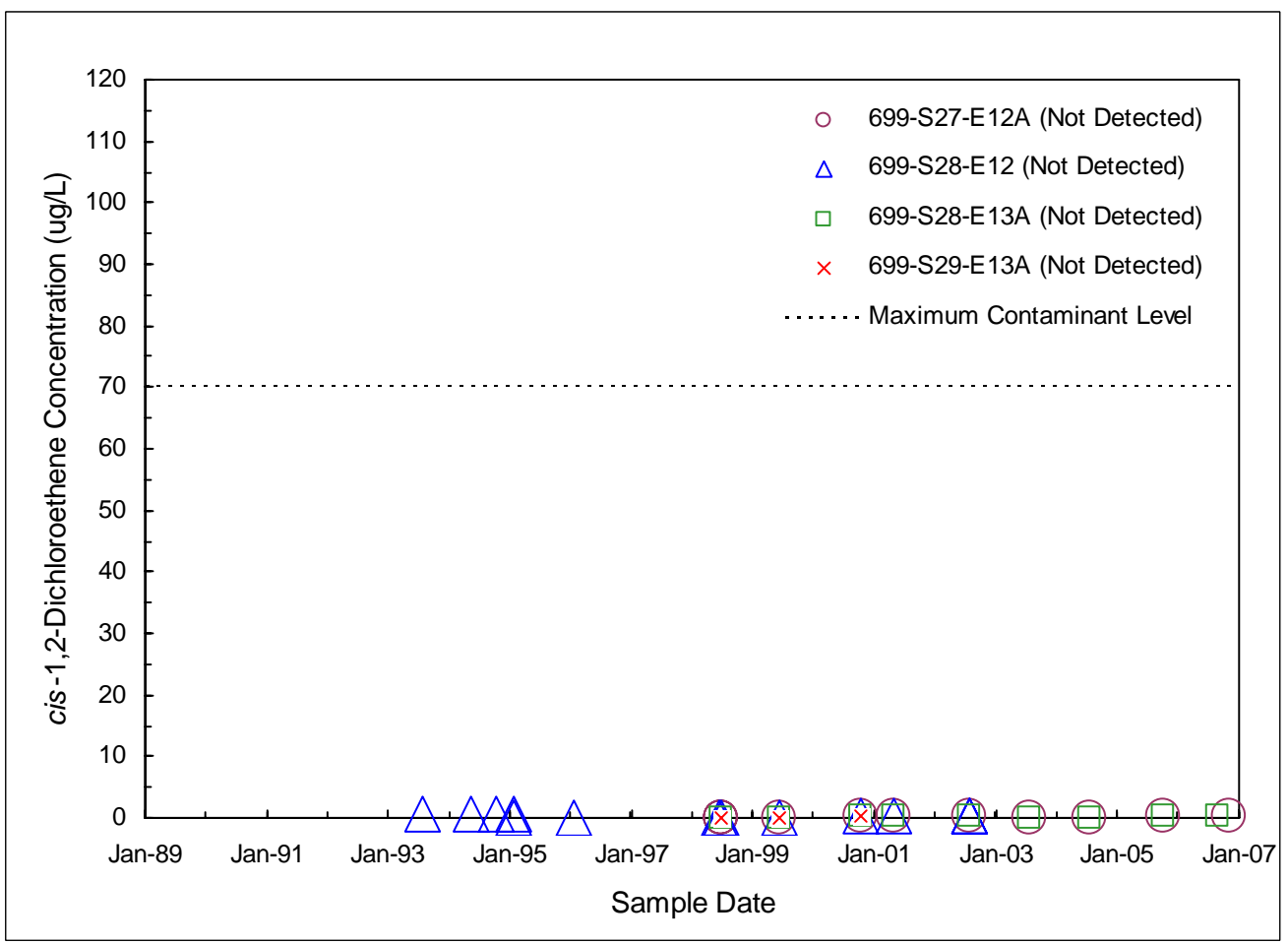

Figure 7.6. cis-1,2-Dichloroethene Concentrations at the Point of Compliance 


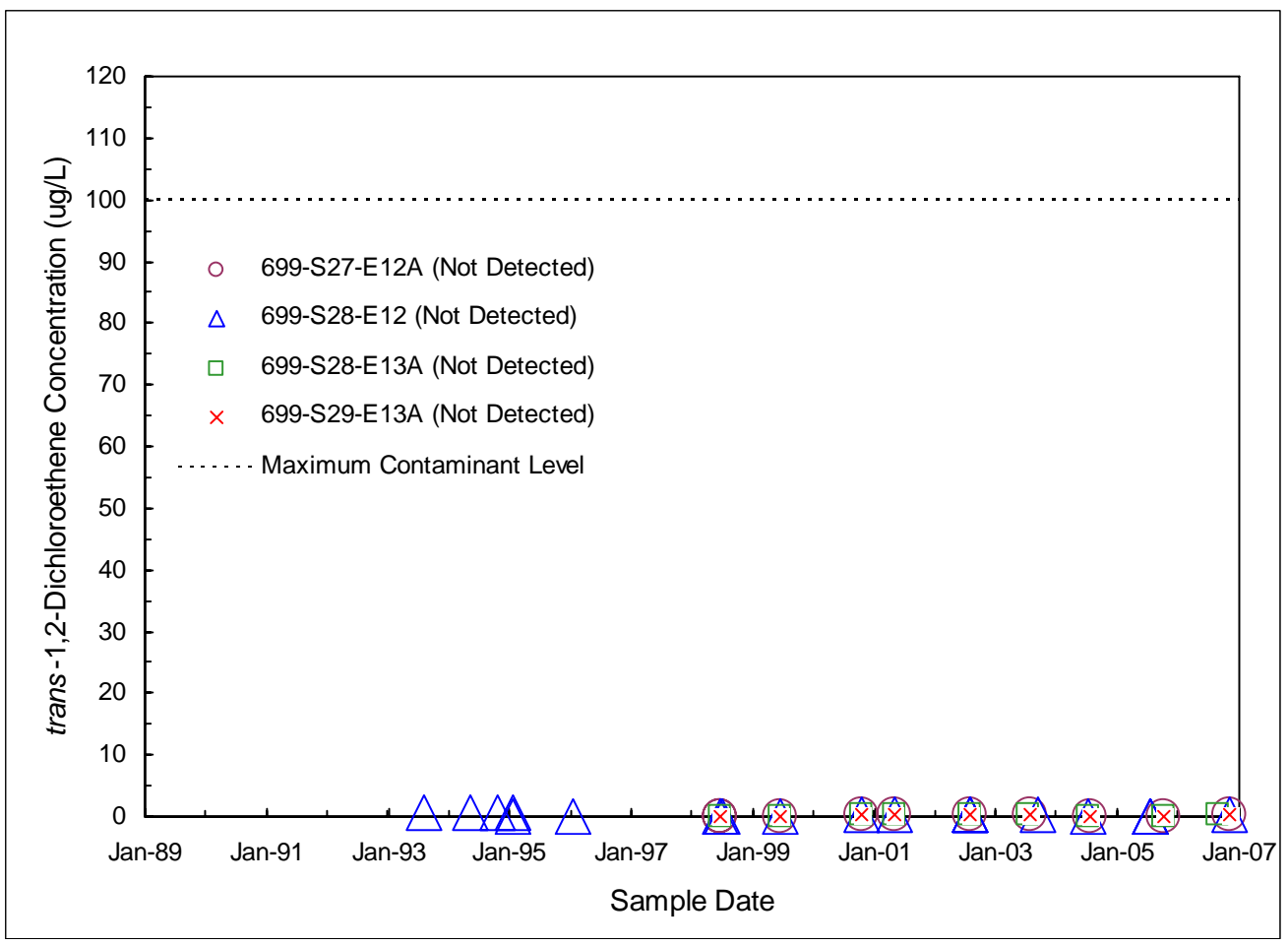

Figure 7.7. trans-1,2-Dichloroethene Concentrations at the Point of Compliance

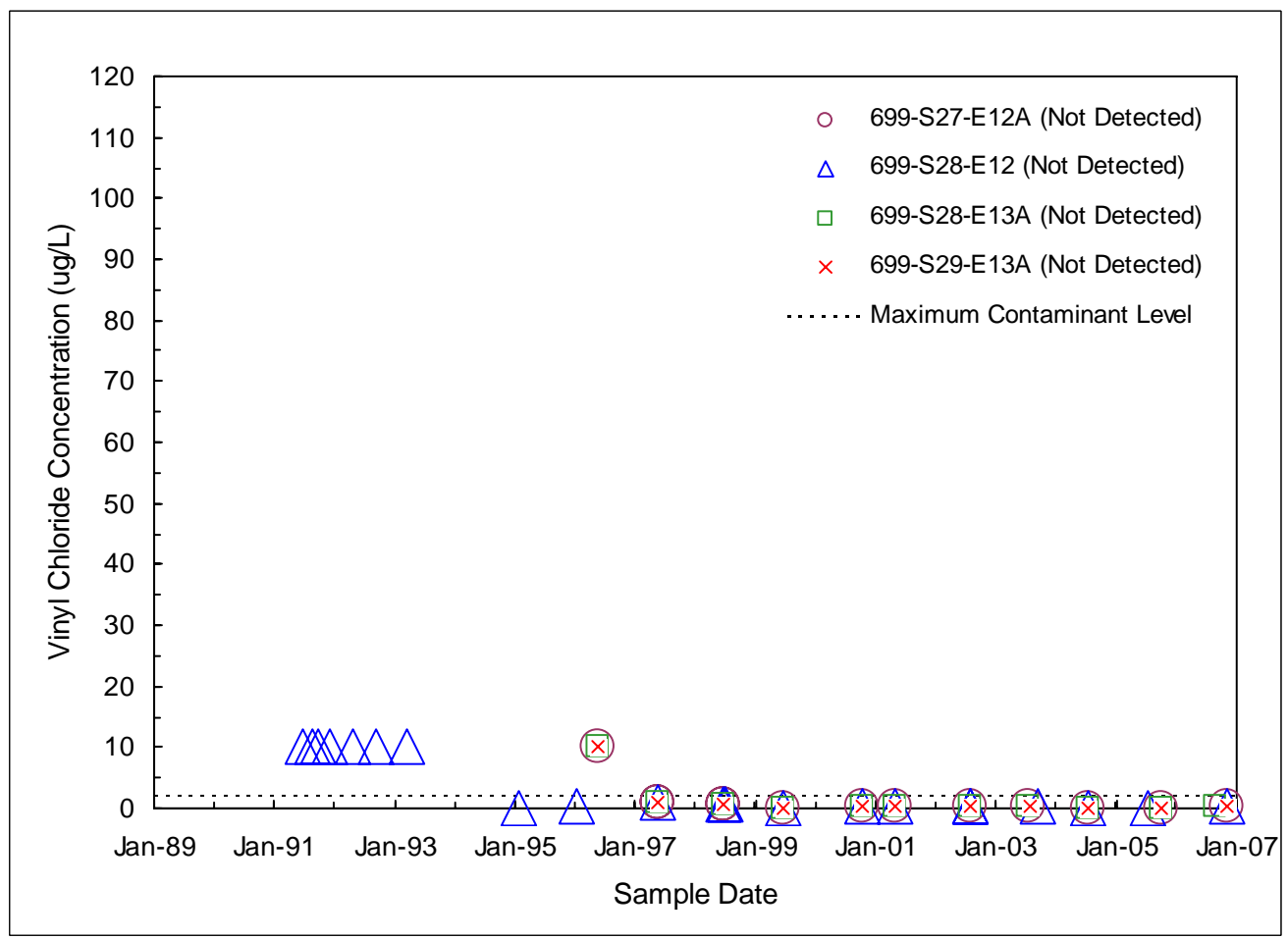

Figure 7.8. Vinyl Chloride Concentrations at the Point of Compliance 


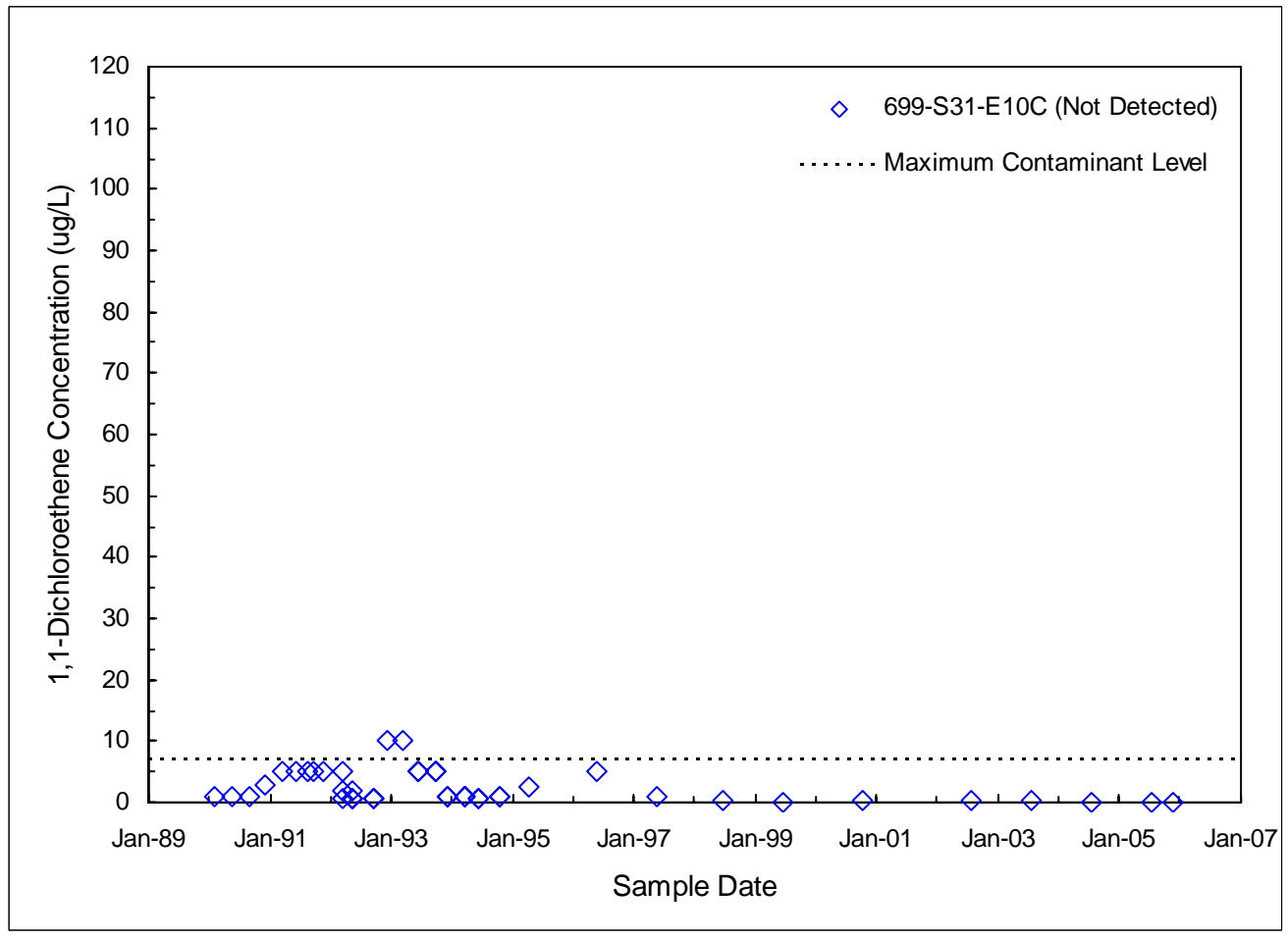

Figure 7.9. 1,1-Dichloroethene Concentrations in the Deep Portion of the Unconfined Aquifer

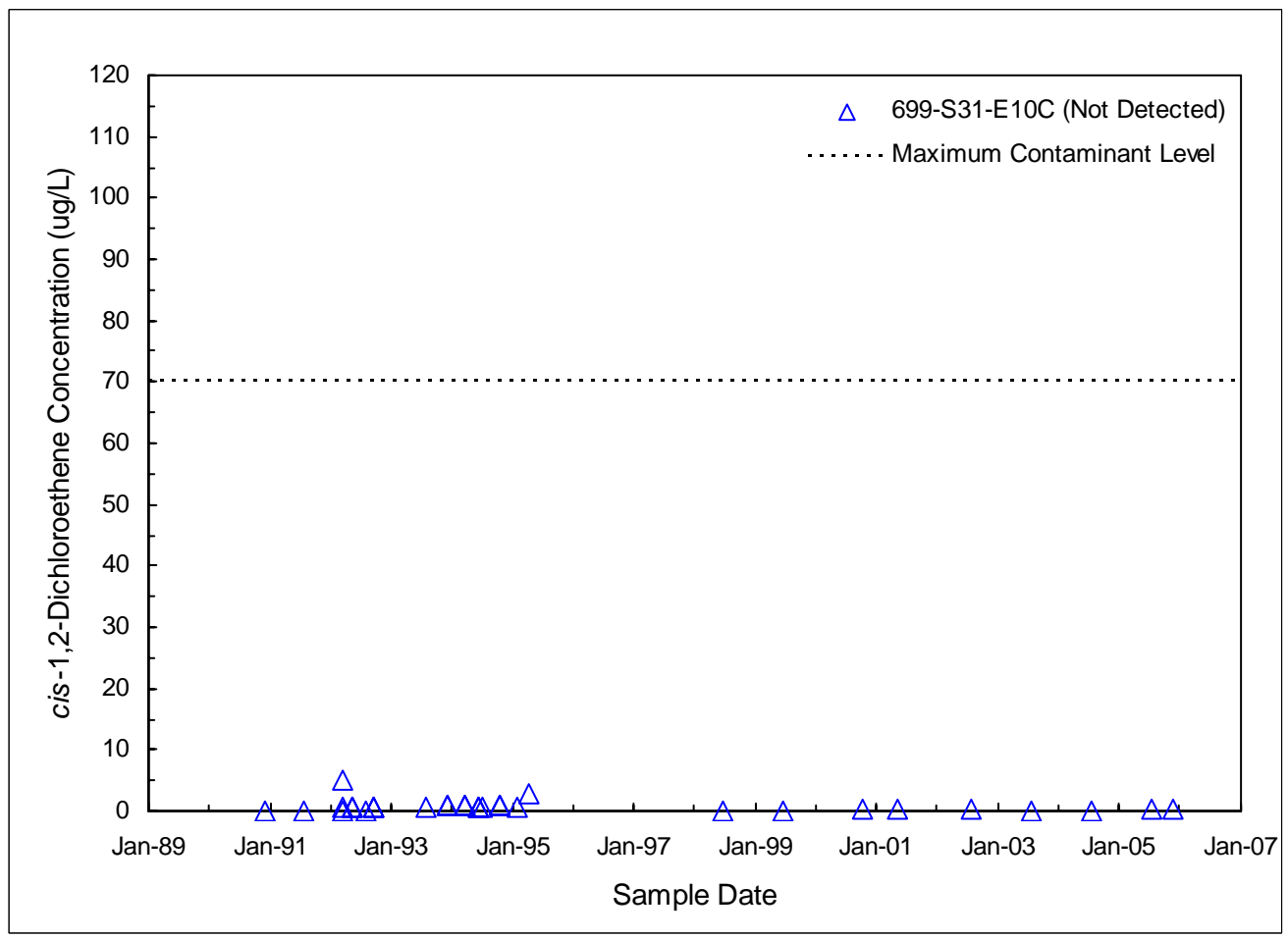

Figure 7.10. cis-1,2-Dichloroethene Concentrations in the Deep Portion of the Unconfined Aquifer 


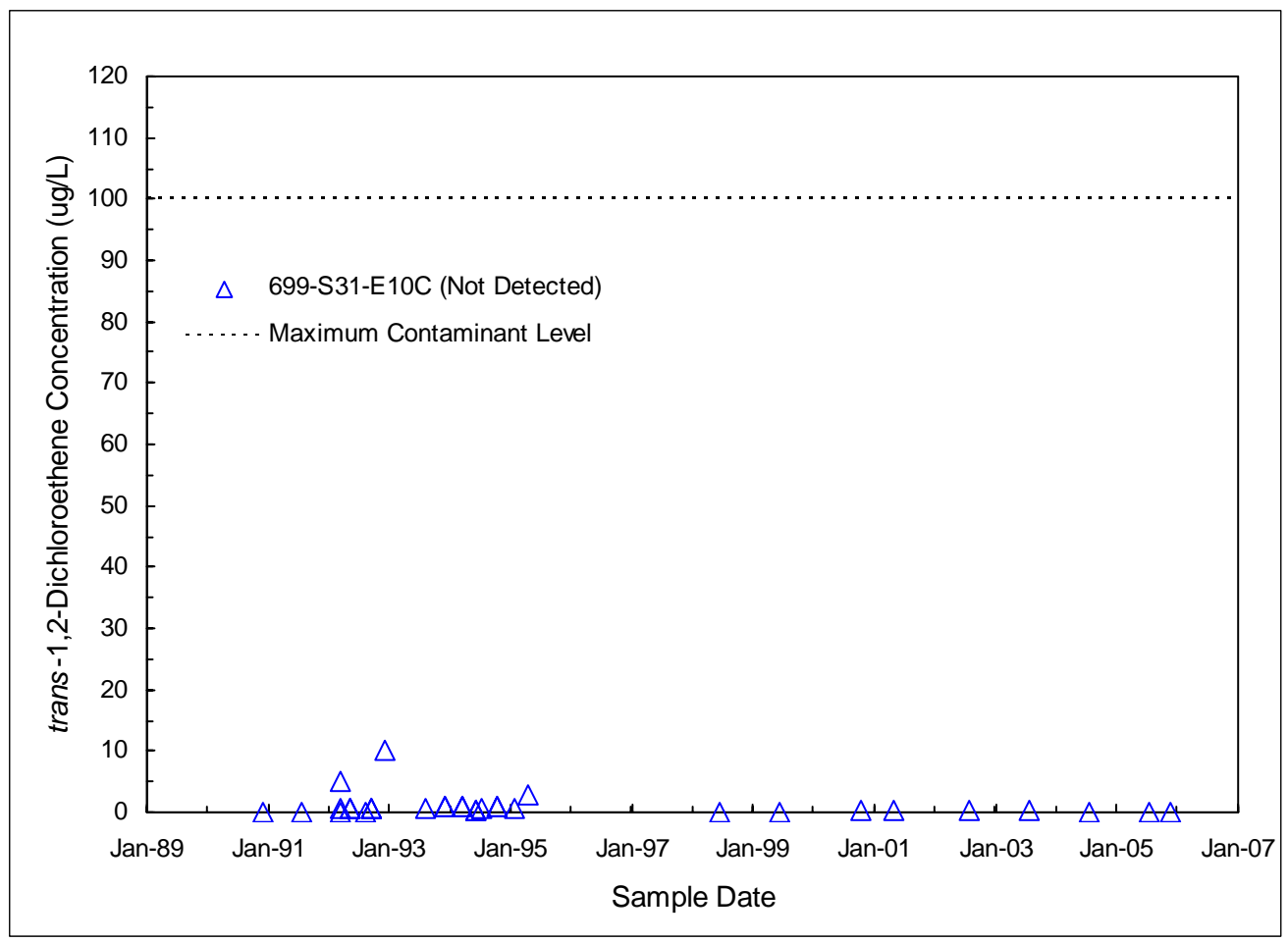

Figure 7.11. trans-1,2-Dichloroethene Concentrations in the Deep Portion of the Unconfined Aquifer

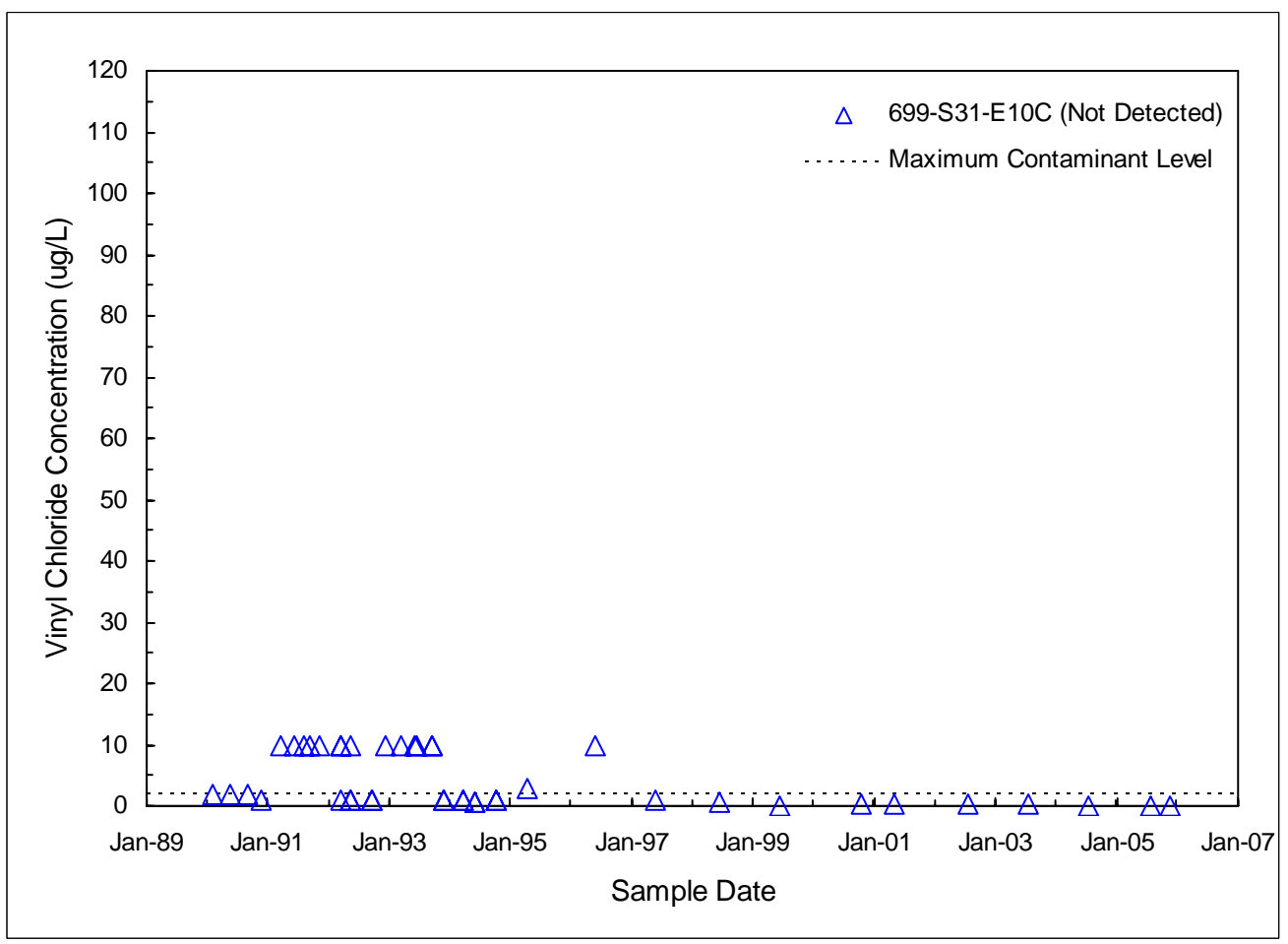

Figure 7.12. Vinyl Chloride Concentrations in the Deep Portion of the Unconfined Aquifer 


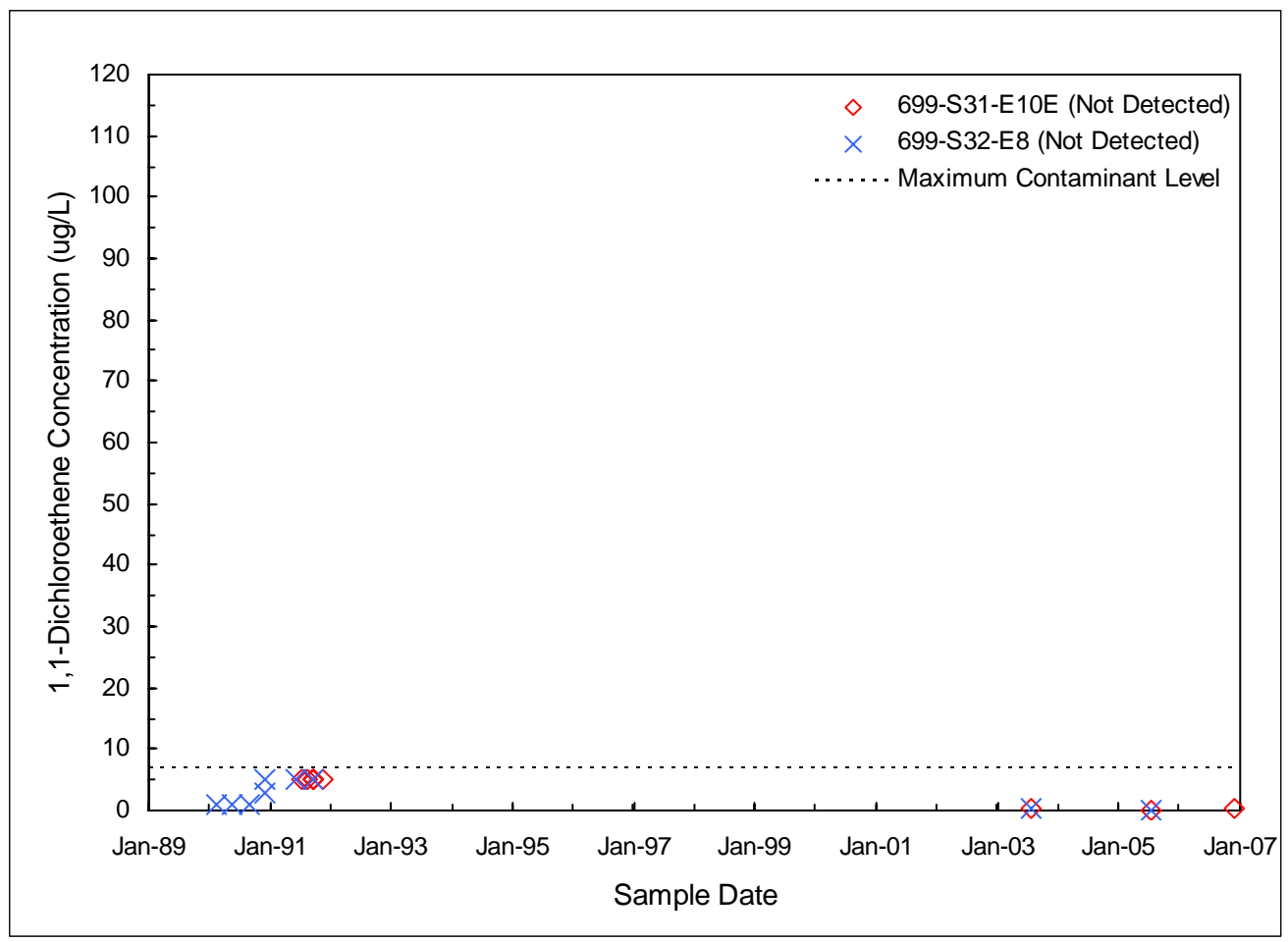

Figure 7.13. 1,1-Dichloroethene Concentrations in the Confined Aquifer

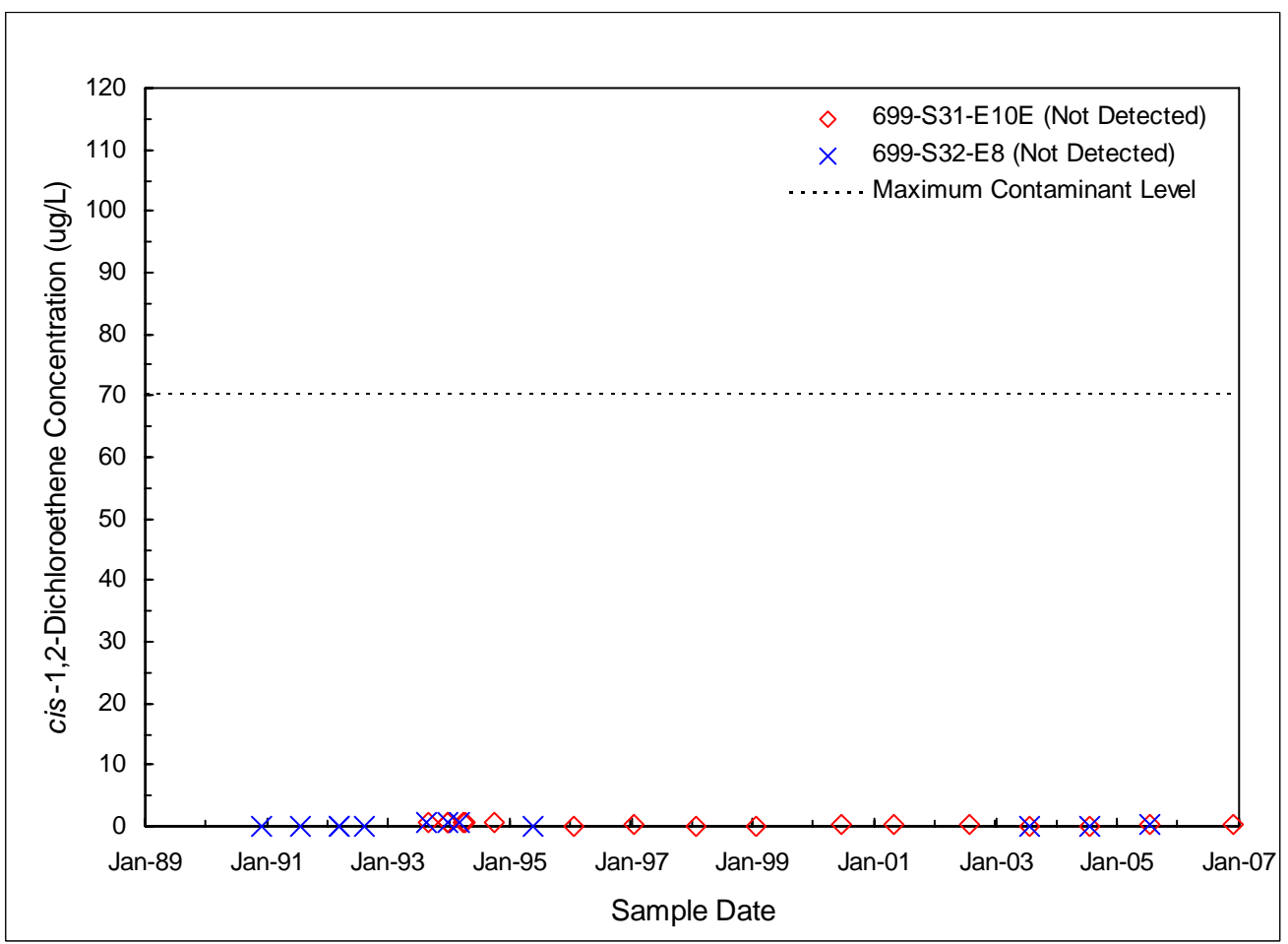

Figure 7.14. cis-1,2-Dichloroethene Concentrations in the Confined Aquifer 


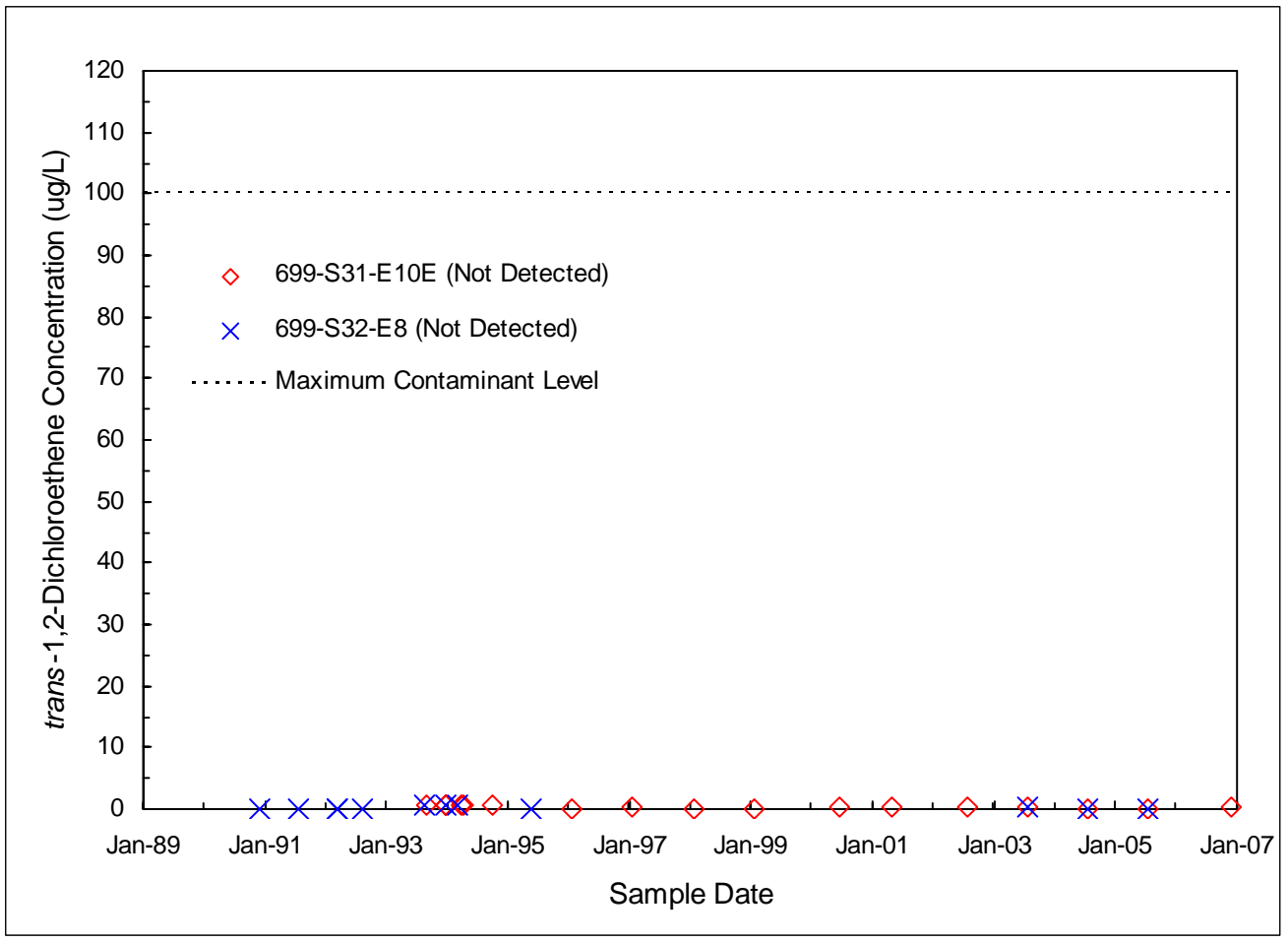

Figure 7.15. trans-1,2-Dichloroethene Concentrations in the Confined Aquifer

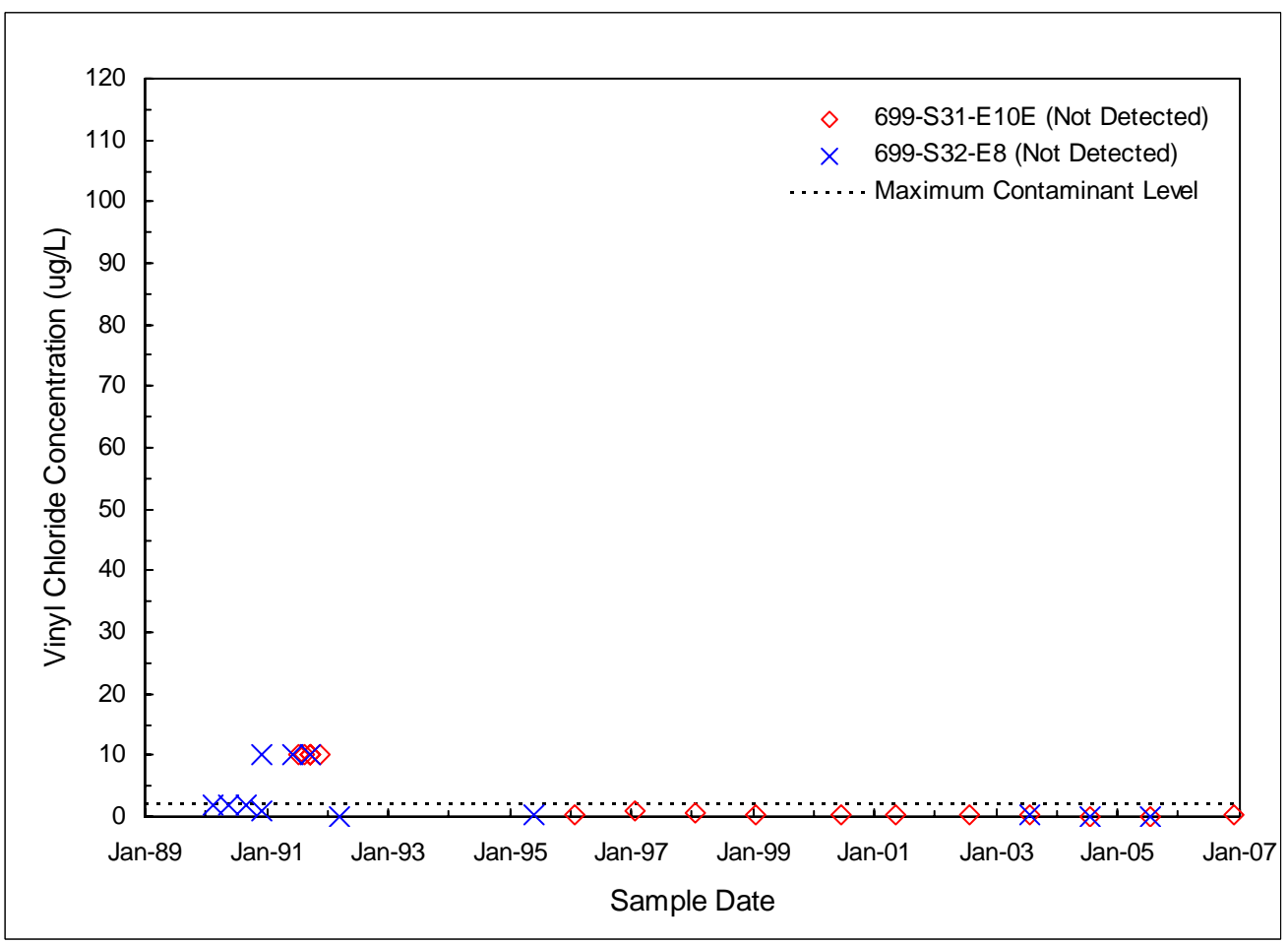

Figure 7.16. Vinyl Chloride Concentrations in the Confined Aquifer 


\subsection{Chromium Results}

Unfiltered chromium was detected at levels above the MCL $(100 \mu \mathrm{g} / \mathrm{L})$ in one well (699-S41-E12) downgradient of the 1171 Building in the mid-1990s. This is illustrated by the plot in Figure 8.1. The plot indicates that unfiltered chromium decreased to levels below the MCL in early 2000 and remained below that level since 2000. Filtered chromium levels at this well have ranged from undetectable to $11 \mu \mathrm{g} / \mathrm{L}$, far below the MCL. Samples collected from this well represent groundwater in the top of the unconfined aquifer.

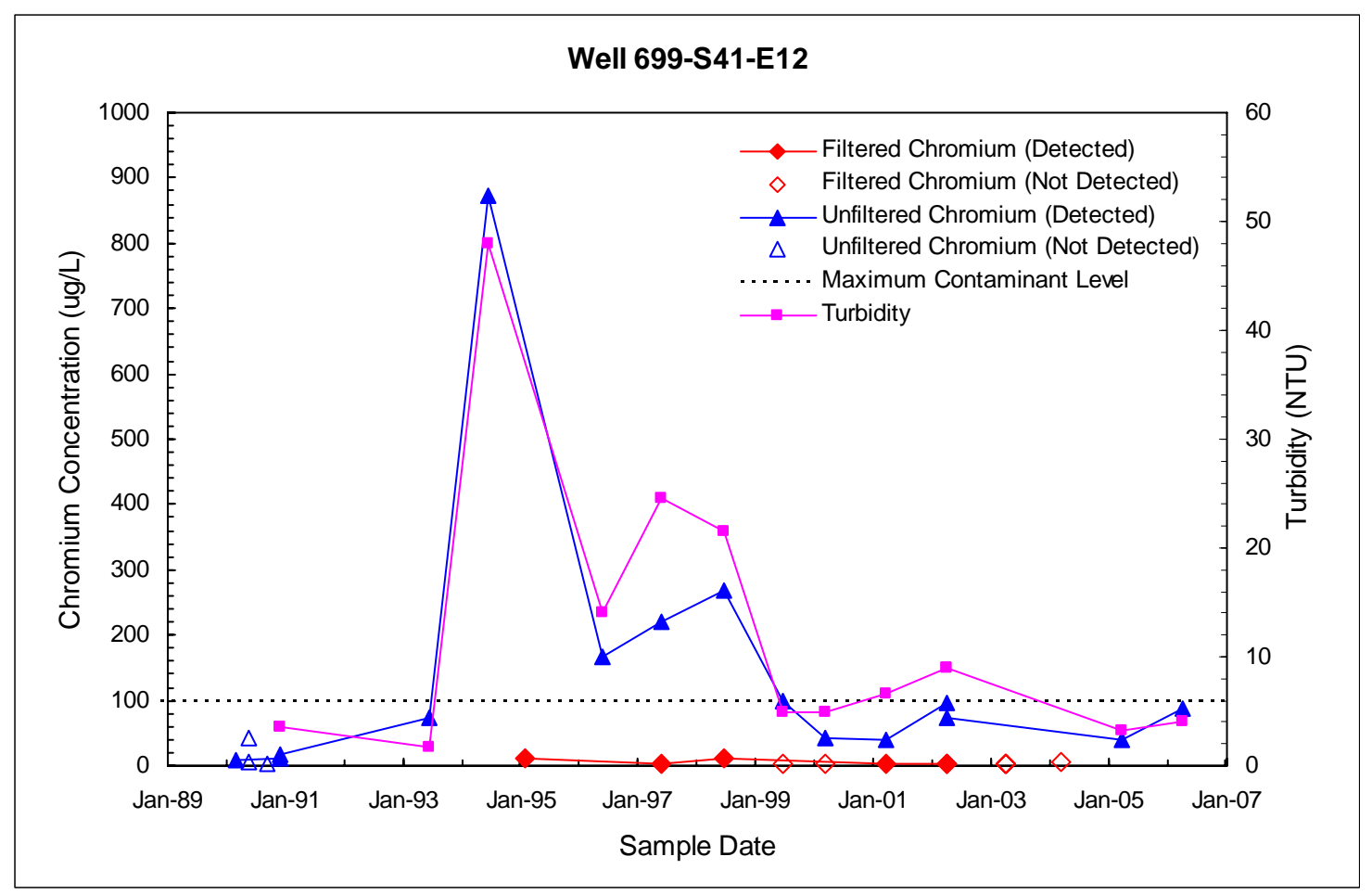

Figure 8.1. Filtered and Unfiltered Chromium Concentrations Near the 1171 Building 


\subsection{Conceptual Model}

The trend plots and the shape and extent of the TCE plume beneath the HRL indicates that the TCE source is not continuous and is from a single source area upgradient of the HRL. TCE contamination occurs in the top and deep portions of the unconfined aquifer in a dissolved state, and there is no evidence that TCE occurs in a dense, nonaqueous-phase liquid state. Assuming a source area at the former AREVA lagoons, any spillage or excess solvent released during liner installation would have had a short pathway from the surface to the water table. Any excess solvents that contacted the soils by spillage would have been driven downward into the vadose zone and groundwater, which is very shallow in this area. Near the lagoons, the depth to the water table varies from $\sim 3$ to $4 \mathrm{~m}$ ( 9 to $14 \mathrm{ft}$ ) below ground surface.

On reaching groundwater, TCE is very mobile and moves in the direction of the prevailing flow path near the top of the unconfined aquifer. Dissolved TCE concentrations in the top of the unconfined aquifer initially increased rapidly near the source area. TCE concentrations near the source then decreased as the plume spread out by advection and dispersion in the aquifer. The TCE plume continued to spread as it moved downgradient to the northeast. The TCE plume migrated from the HRL area to the southwestern corner of the 300 Area. The plume also spread downward within the unconfined aquifer to the top of the aquitard but did not penetrate through the aquitard to the underlying confined aquifer. The decrease in TCE concentrations in the majority of wells suggests that elements of natural attenuation (i.e., dispersion, volatilization) have reduced the plume mass.

Under anaerobic conditions, TCE could degrade naturally to dichloroethene isomers and vinyl chloride through a biological process called reductive dehalogenation (Wiedemeier et al. 1994). However, these breakdown products have not been detected in groundwater near the HRL. 


\subsection{Conclusions}

The data presented indicate that TCE contaminant concentrations in the unconfined aquifer have diminished over time near the HRL. The data suggest that the TCE contamination is a result of a onetime release event. The plume mass most likely decreased because of natural attenuation processes, including dispersion and volatilization. By FY 2001, TCE concentrations were less than the 5- $\mu \mathrm{g} / \mathrm{L}$ maximum contaminant level in all wells monitored near the HRL area and have continued to remain below the maximum contaminant level through 2006. No degradation products of TCE have been detected in groundwater near the HRL.

Unfiltered chromium concentrations near the 1171 Building have been below the $100-\mu \mathrm{g} / \mathrm{L}$ maximum contaminant level since 1999. Elevated unfiltered chromium concentrations are related to elevated turbidity levels measured during sample collection. Filtered chromium concentrations have been detected at levels near the detection limit, well below the MCL.

Based on results contained in this report, it is recommended that annual groundwater monitoring for TCE continue in three wells near the inactive HRL: one well at the point of compliance, one well monitoring the top of the unconfined aquifer immediately downgradient of the HRL, and one well monitoring the deep portion of the unconfined aquifer immediately downgradient of the HRL. 


\subsection{References}

DOE. 1990. Phase 1 Remedial Investigation Report for the Hanford Site 1100-EM-1 Operable Unit. DOE/RL-90-18, U.S. Department of Energy, Richland Operations Office, Richland, Washington.

DOE. 1992a. Draft Remedial Investigation/Feasibility Study for the 1100-EM-1 Operable Unit, Hanford. DOE/RL-92-67, Vol. 1, Draft B, U.S. Department of Energy, Richland Operations Office, Richland, Washington.

DOE. 1992b. Draft Remedial Investigation/Feasibility Study for the 1100-EM-1 Operable Unit, Hanford. DOE/RL-92-67, Vol. 2. Draft B, U.S. Department of Energy, Richland Operations Office, Richland, Washington.

DOE. 1993. Phase I Remedial Investigation Report for the 300-FF-5 Operable Unit. DOE/RL-93-21, Vol. 1, U.S. Department of Energy, Richland Operations Office, Richland, Washington.

DOE. 1995a. Additional Monitoring Well Installation and Field Sampling Plan for Continued Groundwater Monitoring at the Horn Rapids Landfill. DOE/RL-95-50, prepared by the Department of the Army, Walla Walla District, Corps of Engineers, Walla Walla Washington for the U.S. Department of Energy, Richland Operations Office, Richland, Washington.

DOE. 1995b. Remedial Investigation/Feasibility Study Report for the 300-FF-5 Operable Unit. DOE/RL-94-85, Draft A, U.S. Department of Energy, Richland Operations, Office, Richland, Washington.

DOE. 2006. The Second CERCLA Five-Year Review Report for the Hanford Site. DOE/RL-2006-20, Rev. 0, U.S. Department of Energy, Richland, Washington.

Dresel PE, PD Thorne, SP Luttrell, BM Gillespie, WD Webber, JK Merz, JT Rieger, MA Chamness, SK Wurstner, and BE Opitz. 1995. Hanford Site Ground-Water Monitoring for Fiscal Year 1994. PNL-10698, Pacific Northwest National Laboratory, Richland, Washington.

E06-02-2006. 2007. 2006 Annual RCRA Report - Groundwater Quality Assessment Program. AREVA, Richland, Washington.

EPA. 1989. "Method 502.2. Volatile Organic Compounds in Water by Purge and Trap Capillary Column Gas Chromatography with Photoionization and Eclectrolytica Conductivity Detectors in Series.” Revision 2.0, U.S. Environmental Protection Agency, Washington, D.C.

EPA. 1993. Record of Decision for the USDOE Hanford 1100 Area Final Remedial Action. EPA/ROD/R10-93/063, U.S. Environmental Protection Agency, Region 10, Seattle, Washington.

EPA. 1996. "Method 6010B. Inductively Coupled Plasma Atomic Emission Spectrometry.” In Test Methods for Evaluating Solid Wastes: Physical/Chemical Methods. EPA SW-846, U.S. Environmental Protection Agency, Office of Solid Waste and Emergency Response, Washington, D.C. 
EPA. 1996. "Method 8260. Volatile Organic Compounds by Gas Chromatography/Mass Spectrometry (GC/MS).” In Test Methods for Evaluating Solid Wastes: Physical/Chemical Methods. EPA SW-846, U.S. Environmental Protection Agency, Office of Solid Waste and Emergency Response, Washington, D.C.

EPA 2001. USDOE Hanford Site First Five-Year Review Report. U.S. Environmental Protection Agency, Region 10, Seattle, Washington.

Evans JC. 1989. 1100-EM-1 Soil Gas Survey Final Report. WHC-MR-0072, Westinghouse Hanford Company, Richland, Washington.

Hartman MJ and PE Dresel (eds.). 1997. Hanford Site Groundwater Monitoring for Fiscal Year 1996. PNNL-11470, Pacific Northwest National Laboratory, Richland, Washington.

Hartman MJ (ed.). 1999. Hanford Site Groundwater Monitoring for Fiscal Year 1998. PNNL-12086, Pacific Northwest National Laboratory, Richland, Washington.

Hartman MJ, LF Morasch, and WD Webber (eds.). 2006. Hanford Site Groundwater Monitoring for Fiscal Year 2005. PNNL-15670, Pacific Northwest National Laboratory, Richland, Washington.

Hartman MJ, LF Morasch, and WD Webber (eds.). 2007. Hanford Site Groundwater Monitoring for Fiscal Year 2005. PNNL-16346, Pacific Northwest National Laboratory, Richland, Washington.

Liikala TL. 1994. Hydrogeology Along the Southern Boundary of the Hanford Site Between the Yakima and Columbia Rivers, Washington. PNL-10094, Pacific Northwest Laboratory, Richland, Washington.

Newcomer DR. 1999. Sampling and Analysis Plan Update for Groundwater Monitoring - 1100-EM-1 Operable Unit. PNNL-12220, Pacific Northwest National Laboratory, Richland, Washington.

Safe Drinking Water Act. 1974. Public Law 93-523, as amended, 88 Stat. 1660, 42 USC 300f et seq.

Spane FA, Jr., and RG Raymond. 1993. Preliminary Potentiometric Map and Flow Dynamic Characteristics for the Upper-Basalt Confined Aquifer System. PNL-8869, Pacific Northwest Laboratory, Richland, Washington.

Spane FA, Jr., and WD Webber. 1995. Hydrochemistry and Hydrogeologic Conditions Within the Hanford Upper Basalt-Confined Aquifer System. PNL-10817, Pacific Northwest Laboratory, Richland, Washington.

Thorne PD. 1998. Upper Basalt-Confined Aquifer System in the Southern Hanford Site. PNNL-12067, Pacific Northwest National Laboratory, Richland, Washington.

WAC 173-340. “Model Toxics Control Act-Cleanup.” Washington Administrative Code, Olympia, Washington.

Wiedemeier TH, MA Swanson, DE Moutoux, E Kinzie, JT Wilson, BH Wilson, DH Kampbell, PE Haas, RN Miller, JE Hansen, and FH Chapelle 1998. Technical Protocol for Evaluating Natural Attenuation of Chlorinated Solvents in Ground Water. EPA/600/R-98/128, U.S. Environmental Protection Agency, Cincinnati, Ohio. 
Appendix

Groundwater Analysis Results for the 1100-EM-1 Operable Unit 
Chromium in Wells at the 1100 Operable Unit

\begin{tabular}{|c|c|c|c|c|c|c|c|c|}
\hline Well Name & Constituent & Method Name & Sample Date/Time & Value & Units & $\begin{array}{l}\text { Filtered / } \\
\text { Unfiltered }\end{array}$ & $\begin{array}{c}\text { Lab } \\
\text { Qualifier }\end{array}$ & $\begin{array}{l}\text { Review } \\
\text { Qualifier }\end{array}$ \\
\hline 699-S41-E12 & Chromium & CLP_METALS_ICP & $3 / 2 / 19906: 19$ AM & 8.8 & ug/L & Unfiltered & $\mathrm{B}$ & \\
\hline 699-S41-E12 & Chromium & CLP_METALS_ICP & 5/16/1990 3:07 PM & & ug/L & Unfiltered & $U^{*}$ & \\
\hline 699-S41-E12 & Chromium & CLP_METALS_ICP & 5/16/1990 3:07 PM & 41.5 & ug/L & Unfiltered & * & \\
\hline 699-S41-E12 & Chromium & CLP_METALS_ICP & 9/5/1990 5:12 AM & 4 & ug/L & Unfiltered & $U$ & \\
\hline 699-S41-E12 & Chromium & CLP_METALS_ICP & 12/4/1990 5:47 AM & 16.7 & $\mathrm{ug} / \mathrm{L}$ & Unfiltered & & \\
\hline 699-S41-E12 & Chromium & CLP_METALS_ICP & 12/4/1990 5:47 AM & 10.9 & ug/L & Unfiltered & & \\
\hline 699-S41-E12 & Chromium & 6010_METALS_ICP & 6/9/1993 4:34 AM & 73.8 & $\mathrm{ug} / \mathrm{L}$ & Unfiltered & & \\
\hline 699-S41-E12 & Chromium & 6010_METALS_ICP & 6/9/1994 7:52 AM & 872 & ug/L & Unfiltered & & \\
\hline 699-S41-E12 & Chromium & 6010_METALS_ICP & 5/21/1996 9:45 AM & 168 & $\mathrm{ug} / \mathrm{L}$ & Unfiltered & & \\
\hline 699-S41-E12 & Chromium & 6010_METALS_ICP & 5/22/1997 9:23 AM & 220 & $\mathrm{ug} / \mathrm{L}$ & Unfiltered & & \\
\hline 699-S41-E12 & Chromium & 6010_METALS_ICP & 6/19/1998 11:33 AM & 269 & $\mathrm{ug} / \mathrm{L}$ & Unfiltered & & \\
\hline 699-S41-E12 & Chromium & 6010_METALS_ICP & 6/14/1999 2:16 PM & 100 & ug/L & Unfiltered & & \\
\hline 699-S41-E12 & Chromium & 6010_METALS_ICP & $3 / 7 / 20001: 08 \mathrm{PM}$ & 41.9 & ug/L & Unfiltered & & \\
\hline 699-S41-E12 & Chromium & 6010_METALS_ICP & 3/21/2001 9:43 AM & 40.4 & ug/L & Unfiltered & & \\
\hline 699-S41-E12 & Chromium & 6010_METALS_ICP & 3/28/2002 11:58 AM & 72.9 & ug/L & Unfiltered & & $\mathrm{Q}$ \\
\hline 699-S41-E12 & Chromium & 6010_METALS_ICP & $3 / 28 / 200211: 58$ AM & 96.2 & ug/L & Unfiltered & & $\mathrm{Q}$ \\
\hline 699-S41-E12 & Chromium & 6010_METALS_ICP & 3/22/2005 11:32 AM & 39.9 & $\mathrm{ug} / \mathrm{L}$ & Unfiltered & & \\
\hline 699-S41-E12 & Chromium & 6010_METALS_ICP & 3/29/2006 12:09 PM & 86.2 & ug/L & Unfiltered & & \\
\hline 699-S41-E12 & Chromium & 6010_METALS_ICP & 1/27/1995 8:30 AM & 11 & ug/L & Filtered & $L$ & \\
\hline 699-S41-E12 & Chromium & 6010_METALS_ICP & 5/22/1997 9:23 AM & 3.3 & $\mathrm{ug} / \mathrm{L}$ & Filtered & B & \\
\hline 699-S41-E12 & Chromium & 6010_METALS_ICP & 6/19/1998 11:33 AM & 10 & ug/L & Filtered & & \\
\hline 699-S41-E12 & Chromium & 6010_METALS_ICP & 6/14/1999 2:16 PM & 3.3 & $\mathrm{ug} / \mathrm{L}$ & Filtered & $\bar{U}$ & \\
\hline 699-S41-E12 & Chromium & 6010_METALS_ICP & 3/7/2000 1:08 PM & 3 & ug/L & Filtered & $\mathrm{U}$ & \\
\hline 699-S41-E12 & Chromium & 6010_METALS_ICP & 3/21/2001 9:43 AM & 2.7 & ug/L & Filtered & $\mathrm{B}$ & \\
\hline 699-S41-E12 & Chromium & 6010_METALS_ICP & 3/28/2002 11:58 AM & 2.9 & ug/L & Filtered & $B$ & \\
\hline 699-S41-E12 & Chromium & 6010_METALS_ICP & $3 / 28 / 2002$ 11:58 AM & 3.5 & ug/L & Filtered & $\mathrm{B}$ & \\
\hline 699-S41-E12 & Chromium & 6010_METALS_ICP & 3/27/2003 9:16 AM & 3.8 & ug/L & Filtered & $\mathrm{U}$ & \\
\hline 699-S41-E12 & Chromium & 6010_METALS_ICP & 3/27/2003 9:16 AM & 3.8 & ug/L & Filtered & $\mathrm{U}$ & \\
\hline 699-S41-E12 & Chromium & 6010_METALS_ICP & 3/10/2004 1:05 PM & 4.4 & ug/L & Filtered & $\mathrm{U}$ & \\
\hline \multicolumn{9}{|c|}{$\begin{array}{l}* \text { = Duplicate analysis not within control limits. } \\
\text { B = The analyte was detected at a value less than the contract-required detection limit, but greater than or equal to the instrument detection } \\
\quad \text { limit/minimum detection limit. } \\
\mathrm{L}=\text { Minimum detection limit is equal to or less than the value, which is less than the contract-required detection limit. } \\
\mathrm{U}=\text { Analyzed for but not detected above the limiting criteria. } \\
\mathrm{Q}=\text { Associated quality control sample is out of limits. }\end{array}$} \\
\hline
\end{tabular}


Volatile Organic Analysis of Wells at the 1100 Operable Unit

\begin{tabular}{|c|c|c|c|c|c|c|c|}
\hline Well Name & Constituent & Method Name & Sample Date/Time & Value & Units & \begin{tabular}{|c|} 
Lab \\
Qualifier \\
\end{tabular} & \begin{tabular}{|l|} 
Review \\
Qualifier \\
\end{tabular} \\
\hline 699-S27-E12A & 1,1-Dichloroethene & 8240_VOA_GCMS & 5/20/1996 10:10 AM & & $\mathrm{ug} / \mathrm{L}$ & $U$ & \\
\hline 699-S27-E12A & 1,1-Dichloroethene & 8260_VOA_GCMS & 5/22/1997 10:24 AM & & ug/L & $\mathrm{U}$ & \\
\hline 699-S27-E12A & 1,1-Dichloroethene & 8260_VOA_GCMS & 5/22/1997 10:24 AM & & ug/L & $\mathrm{U}$ & \\
\hline 699-S27-E12A & 1,1-Dichloroethene & 8260_VOA_GCMS & 6/22/1998 1:28 PM & 0.19 & $\mathrm{ug} / \mathrm{L}$ & $\mathrm{U}$ & \\
\hline 699-S27-E12A & 1,1-Dichloroethene & 8260_VOA_GCMS & 6/14/1999 10:07 AM & 0.15 & $\mathrm{ug} / \mathrm{L}$ & $\mathrm{U}$ & \\
\hline 699-S27-E12A & 1,1-Dichloroethene & 8260_VOA_GCMS & $10 / 11 / 2000$ 10:05 AM & & ug/L & $\mathrm{U}$ & \\
\hline 699-S27-E12A & 1,1-Dichloroethene & 8260_VOA_GCMS & $7 / 25 / 2002$ 10:36 AM & 0.39 & ug/L & $U$ & \\
\hline 699-S27-E12A & 1,1-Dichloroethene & 8260_VOA_GCMS & $7 / 21 / 2003$ 12:52 PM & 0.16 & $\mathrm{ug} / \mathrm{L}$ & $\mathrm{U}$ & \\
\hline 699-S27-E12A & 1,1-Dichloroethene & 8260_VOA_GCMS & 7/14/2004 11:01 AM & 0.07 & $\mathrm{ug} / \mathrm{L}$ & $\mathrm{U}$ & \\
\hline 699-S27-E12A & 1,1-Dichloroethene & 8260_VOA_GCMS & 9/29/2005 9:55 AM & 0.04 & $u g / L$ & $\mathrm{U}$ & \\
\hline 699-S27-E12A & 1,1-Dichloroethene & 8260_VOA_GCMS & 11/6/2006 12:12 PM & 0.21 & $\mathrm{ug} / \mathrm{L}$ & $\mathrm{U}$ & \\
\hline 699-S28-E12 & 1,1-Dichloroethene & CLP_VOA_GCMS & 6/17/1991 11:30 AM & & ug/L & $\mathrm{U}$ & \\
\hline 699-S28-E12 & 1,1-Dichloroethene & CLP_VOA_GCMS & 8/16/1991 8:50 AM & & ug/L & $\mathrm{U}$ & \\
\hline 699-S28-E12 & 1,1-Dichloroethene & CLP_VOA_GCMS & 9/19/1991 7:35 AM & & ug/L & $\mathrm{U}$ & \\
\hline 699-S28-E12 & 1,1-Dichloroethene & CLP_VOA_GCMS & 12/5/1991 12:00 AM & & ug/L & $\mathrm{U}$ & \\
\hline 699-S28-E12 & 1,1-Dichloroethene & CLP_VOA_GCMS & 4/21/1992 12:00 AM & & $\mathrm{ug} / \mathrm{L}$ & U & \\
\hline 699-S28-E12 & 1,1-Dichloroethene & CLP_VOA_GCMS & 9/9/1992 12:00 AM & & $u g / L$ & $U$ & \\
\hline 699-S28-E12 & 1,1-Dichloroethene & CLP_VOA_GCMS & 3/12/1993 9:20 AM & & ug/L & $\mathrm{U}$ & \\
\hline 699-S28-E12 & 1,1-Dichloroethene & 8260 VOA_GCMS & 5/22/1997 12:55 PM & & $u g / L$ & $U$ & \\
\hline 699-S28-E12 & 1,1-Dichloroethene & 8260_VOA_GCMS & 6/19/1998 8:25 AM & 0.19 & ug/L & $\mathrm{U}$ & \\
\hline 699-S28-E12 & 1,1-Dichloroethene & 8260 VOA_GCMS & 6/14/1999 8:50 AM & 0.15 & $u g / L$ & $U$ & \\
\hline 699-S28-E12 & 1,1-Dichloroethene & 8260_VOA_GCMS & 10/11/2000 9:23 AM & 0.23 & ug/L & $\mathrm{U}$ & \\
\hline 699-S28-E12 & 1,1-Dichloroethene & 8260 VOA_GCMS & 7/25/2002 8:53 AM & 0.39 & $u g / L$ & $U$ & \\
\hline 699-S28-E12 & 1,1-Dichloroethene & 8260_VOA_GCMS & $7 / 25 / 20028: 53 \mathrm{AM}$ & 0.39 & $\mathrm{ug} / \mathrm{L}$ & U & \\
\hline 699-S28-E12 & 1,1-Dichloroethene & 8260 VOA_GCMS & 9/10/2003 10:21 AM & 0.16 & $u g / L$ & $U$ & \\
\hline 699-S28-E12 & 1,1-Dichloroethene & 8260_VOA_GCMS & 7/13/2004 11:46 AM & 0.07 & $\mathrm{ug} / \mathrm{L}$ & U & \\
\hline 699-S28-E12 & 1,1-Dichloroethene & 8260 VOA_GCMS & $7 / 14 / 2005$ 10:59 AM & 0.04 & $\mathrm{ug} / \mathrm{L}$ & $U$ & \\
\hline 699-S28-E12 & 1,1-Dichloroethene & 8260_VOA_GCMS & 11/6/2006 12:50 PM & 0.21 & $u g / L$ & U & \\
\hline \begin{tabular}{|l|}
$699-S 28-E 13 A$ \\
\end{tabular} & 1,1-Dichloroethene & 8240 VOA_GCMS & 5/21/1996 12:36 PM & & $u g / L$ & $U$ & \\
\hline 699-S28-E13A & 1,1-Dichloroethene & 8260_VOA_GCMS & 5/22/1997 11:53 AM & & ug/L & $\mathrm{U}$ & \\
\hline \begin{tabular}{|l|}
$699-S 28-E 13 A$ \\
\end{tabular} & 1,1-Dichloroethene & 8260 VOA_GCMS & 6/19/1998 1:17 PM & 0.19 & $u g / L$ & $U$ & \\
\hline 699-S28-E13A & 1,1-Dichloroethene & 8260_VOA_GCMS & 6/14/1999 9:26 AM & 0.15 & $\mathrm{ug} / \mathrm{L}$ & U & \\
\hline 699-S28-E13A & 1,1-Dichloroethene & 8260 VOA_GCMS & 10/11/2000 11:19 AM & 0.23 & $\mathrm{ug} / \mathrm{L}$ & $U$ & \\
\hline 699-S28-E13A & 1,1-Dichloroethene & 8260_VOA_GCMS & $7 / 25 / 2002$ 10:54 AM & 0.39 & ug/L & $\mathrm{U}$ & \\
\hline \begin{tabular}{|l|}
$699-S 28-E 13 A$ \\
\end{tabular} & 1,1-Dichloroethene & 8260 VOA_GCMS & 7/17/2003 11:20 AM & 0.16 & $\mathrm{ug} / \mathrm{L}$ & $U$ & \\
\hline 699-S28-E13A & 1,1-Dichloroethene & 8260_VOA_GCMS & $7 / 13 / 200410: 57 \mathrm{AM}$ & 0.07 & ug/L & $\mathrm{U}$ & \\
\hline \begin{tabular}{|l|}
$699-S 28-E 13 A$ \\
\end{tabular} & 1,1-Dichloroethene & $8260 \_$VOA_GCMS & 9/29/2005 9:08 AM & 0.04 & $\mathrm{ug} / \mathrm{L}$ & $U$ & \\
\hline 699-S28-E13A & 1,1-Dichloroethene & 8260_VOA_GCMS & $8 / 31 / 200611: 20 \mathrm{AM}$ & 0.21 & ug/L & $\mathrm{U}$ & \\
\hline \begin{tabular}{|l|}
$699-S 29-E 10 A$ \\
\end{tabular} & 1,1-Dichloroethene & 8240 VOA_GCMS & 5/20/1996 11:04 AM & & $u g / L$ & $U$ & \\
\hline 699-S29-E10A & 1,1-Dichloroethene & 8260_VOA_GCMS & 5/22/1997 9:44 AM & & $u g / L$ & $\mathrm{U}$ & \\
\hline 699-S29-E10A & 1,1-Dichloroethene & 8260_VOA_GCMS & 6/22/1998 12:39 PM & 0.19 & ug/L & $\mathrm{U}$ & \\
\hline 699-S29-E10A & 1,1-Dichloroethene & 8260_VOA_GCMS & 6/14/1999 10:44 AM & 0.15 & ug/L & $\mathrm{U}$ & \\
\hline \begin{tabular}{|l|}
$699-S 29-E 10 A$ \\
\end{tabular} & 1,1-Dichloroethene & 8260 VOA_GCMS & 10/11/2000 8:00 AM & 0.23 & $\begin{array}{ll}\mathrm{ug} / \mathrm{L} \\
\end{array}$ & $U$ & \\
\hline \begin{tabular}{|l|}
$699-S 29-E 10 A$ \\
\end{tabular} & 1,1-Dichloroethene & 8260 VOA_GCMS & $7 / 25 / 2002$ 11:35 AM & 0.39 & ug/L & $\mathrm{U}$ & \\
\hline 699-S29-E10A & 1,1-Dichloroethene & 8260_VOA_GCMS & 7/17/2003 1:08 PM & 0.16 & ug/L & $\mathrm{U}$ & \\
\hline 699-S29-E10A & 1,1-Dichloroethene & 8260_VOA_GCMS & $7 / 13 / 2004$ 12:28 PM & 0.07 & ug/L & $\mathrm{U}$ & \\
\hline 699-S29-E10A & 1,1-Dichloroethene & 8260 VOA_GCMS & 9/29/2005 11:23 AM & 0.04 & ug/L & $U$ & \\
\hline \begin{tabular}{|l|}
$699-S 29-E 10 A$ \\
\end{tabular} & 1,1-Dichloroethene & 8260_VOA_GCMS & $11 / 30 / 2006$ 11:10 AM & 0.21 & ug/L & $\mathrm{U}$ & \\
\hline 699-S29-E11 & 1,1-Dichloroethene & CLP_VOA_GCMS & 6/27/1991 12:45 PM & & ug/L & $\mathrm{U}$ & \\
\hline 699-S29-E11 & 1,1-Dichloroethene & CLP_VOA_GCMS & 8/13/1991 11:11 AM & & ug/L & $\mathrm{U}$ & \\
\hline 699-S29-E11 & 1,1-Dichloroethene & CLP_VOA_GCMS & 9/17/1991 10:55 AM & & ug/L & $U$ & \\
\hline 699-S29-E11 & 1,1-Dichloroethene & CLP_VOA_GCMS & 11/21/1991 10:17 AM & & ug/L & $\mathrm{U}$ & \\
\hline 699-S29-E11 & 1,1-Dichloroethene & 8260_VOA_GCMS & 9/16/1992 9:35 AM & & ug/L & $\mathrm{U}$ & \\
\hline 699-S29-E11 & 1,1-Dichloroethene & 8240_VOA_GCMS & 12/9/1992 10:02 AM & & ug/L & $\mathrm{UJ}$ & \\
\hline
\end{tabular}




\begin{tabular}{|c|c|c|c|c|c|c|c|}
\hline Well Name & Constituent & Method Name & Sample Date/Time & Value & Units & \begin{tabular}{|c|} 
Lab \\
Qualifier \\
\end{tabular} & $\begin{array}{c}\text { Review } \\
\text { Qualifier } \\
\end{array}$ \\
\hline 699-S29-E11 & 1,1-Dichloroethene & 8240_VOA_GCMS & $3 / 17 / 1993$ 11:23 AM & 10 & ug/L & $U$ & \\
\hline 699-S29-E11 & 1,1-Dichloroethene & 8260_VOA_GCMS & 6/9/1993 6:16 AM & 5 & ug/L & $\mathrm{U}$ & \\
\hline 699-S29-E11 & 1,1-Dichloroethene & 8240_VOA_GCMS & 9/22/1993 12:00 PM & 5 & ug/L & $\mathrm{U}$ & \\
\hline 699-S29-E11 & 1,1-Dichloroethene & 8260_VOA_GCMS & 12/1/1993 11:40 AM & 1 & ug/L & $\mathrm{U}$ & \\
\hline 699-S29-E11 & 1,1-Dichloroethene & 8260_VOA_GCMS & 3/23/1994 9:07 AM & 1 & ug/L & $U$ & \\
\hline 699-S29-E11 & 1,1-Dichloroethene & 8260_VOA_GCMS & 10/11/1994 9:11 AM & 1 & ug/L & $U$ & \\
\hline 699-S29-E11 & 1,1-Dichloroethene & 8260_VOA_GCMS & 10/11/1994 9:45 AM & 1 & ug/L & $\mathrm{U}$ & \\
\hline 699-S29-E11 & 1,1-Dichloroethene & 8260_VOA_GCMS & 4/10/1995 11:00 AM & 2.6 & $\mathrm{ug} / \mathrm{L}$ & UJ & \\
\hline 699-S29-E11 & 1,1-Dichloroethene & 8240_VOA_GCMS & 5/24/1996 12:15 PM & 5 & ug/L & $U$ & \\
\hline 699-S29-E11 & 1,1-Dichloroethene & 8260_VOA_GCMS & 7/25/2002 12:16 PM & 0.39 & ug/L & $U$ & \\
\hline 699-S29-E11 & 1,1-Dichloroethene & 8260_VOA_GCMS & 7/25/2002 12:16 PM & 0.39 & ug/L & $\mathrm{U}$ & \\
\hline 699-S29-E11 & 1,1-Dichloroethene & 8260_VOA_GCMS & 7/17/2003 12:24 PM & 0.16 & ug/L & $\mathrm{U}$ & \\
\hline 699-S29-E11 & 1,1-Dichloroethene & 8260_VOA_GCMS & $7 / 13 / 2004$ 11:45 AM & 0.07 & ug/L & $\mathrm{U}$ & \\
\hline 699-S29-E11 & 1,1-Dichloroethene & 8260_VOA_GCMS & 7/14/2005 11:54 AM & 0.04 & ug/L & $U$ & \\
\hline 699-S29-E11 & 1,1-Dichloroethene & 8260_VOA_GCMS & 12/27/2006 1:20 PM & 0.21 & ug/L & $\mathrm{U}$ & \\
\hline 699-S29-E12 & 1,1-Dichloroethene & CLP_VOA_GCMS & 5/23/1990 9:08 AM & 1 & ug/L & $\mathrm{U}$ & \\
\hline 699-S29-E12 & 1,1-Dichloroethene & CLP_VOA_GCMS & 8/22/1990 1:38 PM & 1 & ug/L & $\mathrm{U}$ & \\
\hline 699-S29-E12 & 1,1-Dichloroethene & CLP_VOA_GCMS & 11/29/1990 10:25 AM & 3 & ug/L & $\mathrm{U}$ & \\
\hline 699-S29-E12 & 1,1-Dichloroethene & CLP_VOA_GCMS & 6/6/1991 1:31 PM & 5 & ug/L & $\mathrm{U}$ & \\
\hline 699-S29-E12 & 1,1-Dichloroethene & CLP_VOA_GCMS & 11/18/1991 12:55 PM & 5 & ug/L & $U$ & \\
\hline 699-S29-E12 & 1,1-Dichloroethene & 8260_VOA_GCMS & 5/14/1992 9:19 AM & 0.5 & ug/L & $\mathrm{U}$ & \\
\hline 699-S29-E12 & 1,1-Dichloroethene & 8260_VOA_GCMS & 9/15/1992 5:40 AM & 0.5 & ug/L & $U$ & \\
\hline 699-S29-E12 & 1,1-Dichloroethene & 8240_VOA_GCMS & 12/9/1992 10:58 AM & 10 & ug/L & $\mathrm{U}$ & \\
\hline 699-S29-E12 & 1,1-Dichloroethene & 8240_VOA_GCMS & 3/17/1993 9:31 AM & 10 & ug/L & $\mathrm{U}$ & \\
\hline 699-S29-E12 & 1,1-Dichloroethene & 8260_VOA_GCMS & 6/9/1993 5:25 AM & 5 & ug/L & $\mathrm{U}$ & \\
\hline 699-S29-E12 & 1,1-Dichloroethene & 8240_VOA_GCMS & 9/22/1993 9:00 AM & 5 & ug/L & $\mathrm{U}$ & \\
\hline 699-S29-E12 & 1,1-Dichloroethene & 8260_VOA_GCMS & 12/1/1993 9:30 AM & 1 & ug/L & $\mathrm{U}$ & \\
\hline 699-S29-E12 & 1,1-Dichloroethene & 8260_VOA_GCMS & 3/22/1994 12:45 PM & 1 & ug/L & $\mathrm{U}$ & \\
\hline 699-S29-E12 & 1,1-Dichloroethene & 8260_VOA_GCMS & 6/8/1994 10:40 AM & 0.6 & ug/L & $U$ & \\
\hline 699-S29-E12 & 1,1-Dichloroethene & 8260_VOA_GCMS & 10/12/1994 12:15 PM & 1 & ug/L & $U$ & \\
\hline 699-S29-E12 & 1,1-Dichloroethene & 8260_VOA_GCMS & 4/11/1995 12:00 PM & 2.6 & ug/L & $U$ & \\
\hline 699-S29-E12 & 1,1-Dichloroethene & 8260_VOA_GCMS & 4/11/1995 1:15 PM & 2.6 & ug/L & $\mathrm{U}$ & \\
\hline 699-S29-E12 & 1,1-Dichloroethene & 8240_VOA_GCMS & 5/20/1996 12:47 PM & 5 & ug/L & $\mathrm{U}$ & \\
\hline 699-S29-E12 & 1,1-Dichloroethene & 8260_VOA_GCMS & 1/20/1999 9:17 AM & 0.15 & ug/L & $U$ & \\
\hline 699-S29-E12 & 1,1-Dichloroethene & 8260_VOA_GCMS & 7/25/2002 9:45 AM & 0.39 & ug/L & $\mathrm{U}$ & \\
\hline 699-S29-E12 & 1,1-Dichloroethene & 8260_VOA_GCMS & $7 / 21 / 2003$ 12:10 PM & 0.16 & ug/L & $\mathrm{U}$ & \\
\hline 699-S29-E12 & 1,1-Dichloroethene & 8260_VOA_GCMS & 7/13/2004 10:01 AM & 0.07 & ug/L & $\mathrm{U}$ & \\
\hline 699-S29-E12 & 1,1-Dichloroethene & 8260_VOA_GCMS & 11/18/2005 10:51 AM & 0.04 & ug/L & $\mathrm{U}$ & \\
\hline 699-S29-E12 & 1,1-Dichloroethene & 8260_VOA_GCMS & 11/6/2006 1:32 PM & 0.21 & ug/L & $U$ & \\
\hline 699-S29-E13A & 1,1-Dichloroethene & 8240_VOA_GCMS & 5/24/1996 12:00 AM & 5 & ug/L & $\mathrm{U}$ & \\
\hline 699-S29-E13A & 1,1-Dichloroethene & 8260_VOA_GCMS & 5/22/1997 11:18 AM & 1 & ug/L & $U$ & \\
\hline 699-S29-E13A & 1,1-Dichloroethene & 8260_VOA_GCMS & 6/24/1998 8:37 AM & 0.19 & ug/L & $\mathrm{U}$ & \\
\hline 699-S29-E13A & 1,1-Dichloroethene & 8260_VOA_GCMS & 6/15/1999 8:27 AM & 0.15 & ug/L & $\mathrm{U}$ & \\
\hline 699-S29-E13A & 1,1-Dichloroethene & 8260_VOA_GCMS & 6/15/1999 8:27 AM & 0.15 & ug/L & $U$ & \\
\hline 699-S29-E13A & 1,1-Dichloroethene & 8260_VOA_GCMS & 10/11/2000 12:38 PM & 0.23 & ug/L & $\mathrm{U}$ & \\
\hline 699-S29-E13A & 1,1-Dichloroethene & 8260_VOA_GCMS & 10/11/2000 12:38 PM & 0.23 & ug/L & $U$ & \\
\hline 699-S29-E13A & 1,1-Dichloroethene & 8260_VOA_GCMS & 7/25/2002 10:17 AM & 0.39 & ug/L & $\mathrm{U}$ & \\
\hline 699-S29-E13A & 1,1-Dichloroethene & 8260_VOA_GCMS & $7 / 22 / 2003$ 12:34 PM & 0.16 & ug/L & $U$ & \\
\hline 699-S29-E13A & 1,1-Dichloroethene & 8260_VOA_GCMS & 7/14/2004 11:47 AM & 0.07 & ug/L & $\mathrm{U}$ & \\
\hline 699-S29-E13A & 1,1-Dichloroethene & 8260_VOA_GCMS & 9/29/2005 12:40 PM & 0.04 & ug/L & $\mathrm{U}$ & \\
\hline 699-S29-E13A & 1,1-Dichloroethene & 8260_VOA_GCMS & 11/6/2006 11:18 AM & 0.21 & ug/L & $U$ & \\
\hline 699-S30-E10A & 1,1-Dichloroethene & CLP_VOA_GCMS & 2/6/1990 10:06 AM & 1 & ug/L & $\mathrm{U}$ & \\
\hline 699-S30-E10A & 1,1-Dichloroethene & CLP_VOA_GCMS & 5/14/1990 1:32 PM & 1 & ug/L & $U$ & \\
\hline 699-S30-E10A & 1,1-Dichloroethene & CLP_VOA_GCMS & 8/27/1990 12:23 PM & 1 & ug/L & $\mathrm{U}$ & \\
\hline 699-S30-E10A & 1,1-Dichloroethene & CLP_VOA_GCMS & 11/28/1990 9:02 AM & 3 & ug/L & $U$ & \\
\hline 699-S30-E10A & 1,1-Dichloroethene & CLP_VOA_GCMS & 11/28/1990 9:02 AM & 3 & ug/L & $U$ & \\
\hline 699-S30-E10A & 1,1-Dichloroethene & CLP_VOA_GCMS & 3/15/1991 8:35 AM & & ug/L & $U$ & \\
\hline
\end{tabular}




\begin{tabular}{|c|c|c|c|c|c|c|}
\hline Well Name & Constituent & Method Name & Sample Date/Time & \begin{tabular}{l|l} 
Value & Units \\
\end{tabular} & \begin{tabular}{|c|} 
Lab \\
Qualifier
\end{tabular} & \begin{tabular}{|l|} 
Review \\
Qualifier \\
\end{tabular} \\
\hline 699-S30-E10A & 1,1-Dichloroethene & CLP_VOA_GCMS & 6/5/1991 1:03 PM & \begin{tabular}{l|l}
5 & $u g / L$ \\
\end{tabular} & $\bar{U}$ & \\
\hline \begin{tabular}{|l|}
$699-S 30-E 10 A$ \\
\end{tabular} & 1,1-Dichloroethene & CLP_VOA_GCMS & 6/5/1991 1:03 PM & \begin{tabular}{l|l}
5 & $u g / L$ \\
\end{tabular} & $\mathrm{U}$ & \\
\hline \begin{tabular}{|l|}
$699-S 30-E 10 A$ \\
\end{tabular} & 1,1-Dichloroethene & CLP_VOA_GCMS & 8/14/1991 7:58 AM & \begin{tabular}{l|l}
5 & $u g / L$ \\
\end{tabular} & $\mathrm{U}$ & \\
\hline \begin{tabular}{|l|}
$699-S 30-E 10 A$ \\
\end{tabular} & 1,1-Dichloroethene & CLP_VOA_GCMS & 9/17/1991 11:53 AM & \begin{tabular}{l|l|}
5 & $u g / L$ \\
\end{tabular} & $\mathrm{U}$ & \\
\hline 699-S30-E10A & 1,1-Dichloroethene & CLP_VOA_GCMS & 11/13/1991 9:23 AM & \begin{tabular}{l|l|}
5 & $u g / L$ \\
\end{tabular} & $\mathrm{U}$ & \\
\hline \begin{tabular}{|l|}
$699-S 30-E 10 A$ \\
\end{tabular} & 1,1-Dichloroethene & 8260 VOA_GCMS & 5/13/1992 8:57 AM & \begin{tabular}{ll|l}
0.5 & $\mathrm{ug} / \mathrm{L}$ \\
\end{tabular} & $U$ & \\
\hline \begin{tabular}{|l|}
$699-S 30-E 10 A$ \\
\end{tabular} & 1,1-Dichloroethene & 8240_VOA_GCMS & 12/7/1992 11:05 AM & \begin{tabular}{l|l|l|}
10 & $u g / L$ \\
\end{tabular} & $\mathrm{U}$ & \\
\hline \begin{tabular}{|l|}
$699-S 30-E 10 A$ \\
\end{tabular} & 1,1-Dichloroethene & 8240_VOA_GCMS & $3 / 15 / 1993$ 11:14 AM & \begin{tabular}{l|l|l|}
10 & ug/L \\
\end{tabular} & $\mathrm{U}$ & \\
\hline \begin{tabular}{|l|}
$699-S 30-E 10 A$ \\
\end{tabular} & 1,1-Dichloroethene & 8260_VOA_GCMS & 6/7/1993 10:07 AM & \begin{tabular}{l|l|l}
5 & $u g / L$ \\
\end{tabular} & $\mathrm{U}$ & \\
\hline \begin{tabular}{|l|}
$699-S 30-E 10 A$ \\
\end{tabular} & 1,1-Dichloroethene & 8240_VOA_GCMS & 9/23/1993 9:00 AM & \begin{tabular}{l|l|}
5 & $u g / L$ \\
\end{tabular} & $\mathrm{U}$ & \\
\hline \begin{tabular}{|l|}
$699-S 30-E 10 A$ \\
\end{tabular} & 1,1-Dichloroethene & 8260 VOA_GCMS & 12/2/1993 9:00 AM & \begin{tabular}{l|l}
1 & $u g / L$ \\
\end{tabular} & $\mathrm{U}$ & \\
\hline 699-S30-E10A & 1,1-Dichloroethene & 8260_VOA_GCMS & 3/21/1994 12:25 PM & \begin{tabular}{l|l}
1 & $u g / L$ \\
\end{tabular} & $\mathrm{U}$ & \\
\hline \begin{tabular}{|c|}
$699-S 30-E 10 A$ \\
\end{tabular} & 1,1-Dichloroethene & 8260_VOA_GCMS & 6/6/1994 12:00 PM & $\begin{array}{l}0.6 \mathrm{ug} / \mathrm{L} \\
\end{array}$ & UJ & \\
\hline 699-S30-E10A & 1,1-Dichloroethene & 8260_VOA_GCMS & 10/11/1994 1:15 PM & \begin{tabular}{l|l|}
1 & ug $/ L$ \\
\end{tabular} & $\mathrm{U}$ & \\
\hline \begin{tabular}{|l|}
$699-S 30-E 10 A$ \\
\end{tabular} & 1,1-Dichloroethene & 8260_VOA_GCMS & 4/10/1995 11:43 AM & \begin{tabular}{l|l|l|l}
$2.6 \mathrm{ug} / \mathrm{L}$ \\
\end{tabular} & UJ & \\
\hline \begin{tabular}{|l|}
$699-S 30-E 10 A$ \\
\end{tabular} & 1,1-Dichloroethene & 8240_VOA_GCMS & 5/22/1996 9:06 AM & \begin{tabular}{l|l|}
5 & $u g / L$ \\
\end{tabular} & $\mathrm{U}$ & \\
\hline 699-S30-E10A & 1,1-Dichloroethene & 8240_VOA_GCMS & 5/22/1996 9:06 AM & \begin{tabular}{l|l|}
5 & ug $/ \mathrm{L}$ \\
\end{tabular} & $\mathrm{U}$ & \\
\hline \begin{tabular}{|l|}
$699-S 30-E 10 A$ \\
\end{tabular} & 1,1-Dichloroethene & 8240 VOA_GCMS & 5/22/1996 9:06 AM & \begin{tabular}{l|l}
5 & $\mathrm{ug} / \mathrm{L}$ \\
\end{tabular} & $U$ & \\
\hline \begin{tabular}{|c|}
$699-S 30-E 10 A$ \\
\end{tabular} & 1,1-Dichloroethene & 8260_VOA_GCMS & 5/22/1997 11:08 AM & \begin{tabular}{l|l}
1 & $u g / L$ \\
\end{tabular} & $U$ & \\
\hline \begin{tabular}{|l|}
$699-S 30-E 10 A$ \\
\end{tabular} & 1,1-Dichloroethene & 8260_VOA_GCMS & 6/22/1998 11:18 AM & \begin{tabular}{ll|l}
0.19 & $\mathrm{ug} / \mathrm{L}$ \\
\end{tabular} & $\mathrm{U}$ & \\
\hline \begin{tabular}{|l|}
$699-S 30-E 10 A$ \\
\end{tabular} & 1,1-Dichloroethene & 8260_VOA_GCMS & 6/14/1999 12:27 PM & \begin{tabular}{ll|l}
0.15 & $\mathrm{ug} / \mathrm{L}$ \\
\end{tabular} & $\mathrm{U}$ & \\
\hline 699-S30-E10A & 1,1-Dichloroethene & 8260_VOA_GCMS & 10/11/2000 12:09 PM & \begin{tabular}{l|l}
0.23 & $\mathrm{ug} / \mathrm{L}$ \\
\end{tabular} & $\mathrm{U}$ & \\
\hline 699-S30-E10A & 1,1-Dichloroethene & 8260_VOA_GCMS & 7/31/2002 10:49 AM & \begin{tabular}{l|l|l}
0.39 & $\mathrm{ug} / \mathrm{L}$ \\
\end{tabular} & $\mathrm{U}$ & \\
\hline 699-S30-E10A & 1,1-Dichloroethene & 8260_VOA_GCMS & 7/22/2003 9:55 AM & \begin{tabular}{l|l}
0.16 & $\mathrm{ug} / \mathrm{L}$ \\
\end{tabular} & $\mathrm{U}$ & \\
\hline 699-S30-E10A & 1,1-Dichloroethene & 8260_VOA_GCMS & 7/15/2004 11:12 AM & \begin{tabular}{ll|l}
0.07 & $\mathrm{ug} / \mathrm{L}$ \\
\end{tabular} & $\mathrm{U}$ & \\
\hline \begin{tabular}{|l|}
$699-S 30-E 10 A$ \\
\end{tabular} & 1,1-Dichloroethene & 8260_VOA_GCMS & 7/14/2005 11:32 AM & \begin{tabular}{ll|l}
0.04 & $\mathrm{ug} / \mathrm{L}$ \\
\end{tabular} & $\mathrm{U}$ & \\
\hline 699-S30-E10A & 1,1-Dichloroethene & 8260_VOA_GCMS & 11/6/2006 12:11 PM & $\begin{array}{ll}0.21 & \mathrm{ug} / \mathrm{L} \\
\end{array}$ & $\mathrm{U}$ & \\
\hline \begin{tabular}{|l|}
$699-S 30-E 10 B$ \\
\end{tabular} & 1,1-Dichloroethene & CLP_VOA_GCMS & 2/6/1990 8:22 AM & \begin{tabular}{l|l}
1 & $u g / L$ \\
\end{tabular} & $\mathrm{U}$ & \\
\hline 699-S30-E10B & 1,1-Dichloroethene & CLP_VOA_GCMS & 2/6/1990 8:22 AM & \begin{tabular}{l|l|l}
1 & $u g / L$ \\
\end{tabular} & $\mathrm{U}$ & \\
\hline 699-S30-E10B & 1,1-Dichloroethene & CLP_VOA_GCMS & 5/15/1990 8:42 AM & \begin{tabular}{l|l|l}
1 & $u g / L$ \\
\end{tabular} & $\mathrm{U}$ & \\
\hline 699-S30-E10B & 1,1-Dichloroethene & CLP_VOA_GCMS & 8/27/1990 1:36 PM & \begin{tabular}{l|l|l}
1 & $u g / L$ \\
\end{tabular} & $\mathrm{U}$ & \\
\hline \begin{tabular}{|l|}
$699-S 30-E 10 B$ \\
\end{tabular} & 1,1-Dichloroethene & CLP_VOA_GCMS & $11 / 28 / 1990$ 11:16 AM & \begin{tabular}{l|l|}
5 & $u g / L$ \\
\end{tabular} & $\mathrm{U}$ & \\
\hline 699-S30-E10B & 1,1-Dichloroethene & CLP_VOA_GCMS & $11 / 28 / 199011: 16 \mathrm{AM}$ & \begin{tabular}{l|l}
3 & $u g / L$ \\
\end{tabular} & $\mathrm{U}$ & \\
\hline 699-S30-E10B & 1,1-Dichloroethene & CLP_VOA_GCMS & 3/15/1991 9:34 AM & \begin{tabular}{l|l|}
5 & $u g / L$ \\
\end{tabular} & $\mathrm{U}$ & \\
\hline \begin{tabular}{|l|}
$699-S 30-E 10 B$ \\
\end{tabular} & 1,1-Dichloroethene & CLP_VOA_GCMS & 3/15/1991 9:34 AM & \begin{tabular}{l|l}
5 & $\mathrm{ug} / \mathrm{L}$ \\
\end{tabular} & $U$ & \\
\hline 699-S30-E10B & 1,1-Dichloroethene & CLP_VOA_GCMS & 6/5/1991 1:42 PM & \begin{tabular}{l|l}
5 & $\mathrm{ug} / \mathrm{L}$ \\
\end{tabular} & $\mathrm{U}$ & \\
\hline 699-S30-E10B & 1,1-Dichloroethene & CLP_VOA_GCMS & 6/5/1991 1:42 PM & \begin{tabular}{l|l}
5 & $u g / L$ \\
\end{tabular} & $\mathrm{U}$ & \\
\hline 699-S30-E10B & 1,1-Dichloroethene & CLP_VOA_GCMS & 8/14/1991 6:55 AM & \begin{tabular}{l|l|l}
5 & $u g / L$ \\
\end{tabular} & $\mathrm{U}$ & \\
\hline 699-S30-E10B & 1,1-Dichloroethene & CLP_VOA_GCMS & 8/14/1991 6:55 AM & \begin{tabular}{l|l|l}
5 & $u g / L$ \\
\end{tabular} & $\mathrm{U}$ & \\
\hline 699-S30-E10B & 1,1-Dichloroethene & CLP_VOA_GCMS & 8/14/1991 6:55 AM & \begin{tabular}{l|l}
5 & $\mathrm{ug} / \mathrm{L}$ \\
\end{tabular} & $\mathrm{U}$ & \\
\hline 699-S30-E10B & 1,1-Dichloroethene & CLP_VOA_GCMS & 9/17/1991 12:37 PM & \begin{tabular}{l|l|}
5 & $u g / L$ \\
\end{tabular} & $\mathrm{U}$ & \\
\hline 699-S30-E10B & 1,1-Dichloroethene & CLP_VOA_GCMS & 11/13/1991 10:21 AM & \begin{tabular}{l|l|l}
5 & $u g / L$ \\
\end{tabular} & $\mathrm{U}$ & \\
\hline 699-S30-E10B & 1,1-Dichloroethene & 8260_VOA_GCMS & 5/13/1992 9:50 AM & $\begin{array}{l}0.5 \\
\mathrm{ug} / \mathrm{L} \\
\end{array}$ & $\mathrm{U}$ & \\
\hline 699-S30-E10B & 1,1-Dichloroethene & 8260_VOA_GCMS & 9/14/1992 10:00 AM & $\begin{array}{l}0.5 \\
\mathrm{ug} / \mathrm{L} \\
\end{array}$ & $\mathrm{U}$ & \\
\hline 699-S30-E10B & 1,1-Dichloroethene & 8240_VOA_GCMS & 12/7/1992 11:45 AM & \begin{tabular}{l|l|l|}
10 & $u g / L$ \\
\end{tabular} & $\mathrm{U}$ & \\
\hline 699-S30-E10B & 1,1-Dichloroethene & 8240_VOA_GCMS & 3/15/1993 10:38 AM & \begin{tabular}{l|l|l|}
10 & ug/L \\
\end{tabular} & $\mathrm{U}$ & \\
\hline 699-S30-E10B & 1,1-Dichloroethene & 8260_VOA_GCMS & 6/7/1993 10:47 AM & \begin{tabular}{l|l|l}
5 & $u g / L$ \\
\end{tabular} & $\mathrm{U}$ & \\
\hline 699-S30-E10B & 1,1-Dichloroethene & 8240_VOA_GCMS & 9/23/1993 9:42 AM & \begin{tabular}{l|l}
5 & $\mathrm{ug} / \mathrm{L}$ \\
\end{tabular} & $\mathrm{U}$ & \\
\hline \begin{tabular}{|l|}
$699-S 30-E 10 B$ \\
\end{tabular} & 1,1-Dichloroethene & 8260_VOA_GCMS & 12/2/1993 9:40 AM & \begin{tabular}{l|l|l}
1 & $u g / L$ \\
\end{tabular} & $\mathrm{U}$ & \\
\hline 699-S30-E10B & 1,1-Dichloroethene & 8260_VOA_GCMS & 3/21/1994 11:15 AM & \begin{tabular}{l|l}
1 & $u g / L$ \\
\end{tabular} & $\mathrm{U}$ & \\
\hline 699-S30-E10B & 1,1-Dichloroethene & 8260_VOA_GCMS & 6/6/1994 1:25 AM & $\begin{array}{l}0.6 \mathrm{ug} / \mathrm{L} \\
\end{array}$ & $\mathrm{U}$ & \\
\hline 699-S30-E10B & 1,1-Dichloroethene & 8260_VOA_GCMS & 10/11/1994 12:40 PM & \begin{tabular}{l|l|l}
1 & $u g / L$ \\
\end{tabular} & $\mathrm{U}$ & \\
\hline 699-S30-E10B & 1,1-Dichloroethene & 8260_VOA_GCMS & 4/10/1995 12:30 PM & $\begin{array}{l}2.6 \\
\text { ug/L } \\
\end{array}$ & $\mathrm{UJ}$ & \\
\hline \begin{tabular}{|l|}
$699-S 30-E 10 B$ \\
\end{tabular} & 1,1-Dichloroethene & 8240_VOA_GCMS & 5/22/1996 10:25 AM & \begin{tabular}{l|l}
5 & $\mathrm{ug} / \mathrm{L}$ \\
\end{tabular} & U & \\
\hline 699-S30-E10B & 1,1-Dichloroethene & 8240_VOA_GCMS & 5/22/1996 10:25 AM & \begin{tabular}{l|l|l}
5 & $u g / L$ \\
\end{tabular} & $\mathrm{U}$ & \\
\hline 699-S30-E10B & 1,1-Dichloroethene & 8240_VOA_GCMS & 5/22/1996 10:25 AM & \begin{tabular}{l|l|l}
5 & $u g / L$ \\
\end{tabular} & $\mathrm{U}$ & \\
\hline 699-S30-E10B & 1,1-Dichloroethene & 8260_VOA_GCMS & 1/20/1999 12:21 PM & \begin{tabular}{ll|l}
0.15 & $\mathrm{ug} / \mathrm{L}$ \\
\end{tabular} & $\mathrm{U}$ & \\
\hline 699-S30-E10B & 1,1-Dichloroethene & 8260_VOA_GCMS & 7/31/2002 10:13 AM & \begin{tabular}{ll|l}
0.39 & $\mathrm{ug} / \mathrm{L}$ \\
\end{tabular} & U & \\
\hline
\end{tabular}




\begin{tabular}{|c|c|c|c|c|c|c|c|}
\hline Well Name & Constituent & Method Name & Sample Date/Time & Value & Units & $\begin{array}{c}\text { Lab } \\
\text { Qualifier } \\
\end{array}$ & $\begin{array}{c}\text { Review } \\
\text { Qualifier } \\
\end{array}$ \\
\hline 699-S30-E10B & 1,1-Dichloroethene & 8260_VOA_GCMS & 7/21/2003 12:15 PM & 0.16 & ug/L & $U$ & \\
\hline 699-S30-E10B & 1,1-Dichloroethene & 8260_VOA_GCMS & $7 / 15 / 2004$ 10:35 AM & 0.07 & $u g / L$ & $\mathrm{U}$ & \\
\hline 699-S30-E10B & 1,1-Dichloroethene & 8260_VOA_GCMS & $7 / 25 / 2005$ 11:00 AM & 0.04 & $\mathrm{ug} / \mathrm{L}$ & $\mathrm{U}$ & \\
\hline 699-S30-E10B & 1,1-Dichloroethene & 8260_VOA_GCMS & 11/6/2006 12:53 PM & 0.21 & $\mathrm{ug} / \mathrm{L}$ & $\mathrm{U}$ & \\
\hline 699-S30-E11A & 1,1-Dichloroethene & 8240_VOA_GCMS & 5/20/1996 9:20 AM & 5 & ug/L & $U$ & \\
\hline 699-S30-E11A & 1,1-Dichloroethene & 8260_VOA_GCMS & 5/22/1997 8:59 AM & 1 & $u g / L$ & $U$ & \\
\hline 699-S30-E11A & 1,1-Dichloroethene & 8260_VOA_GCMS & 6/19/1998 12:40 PM & 0.19 & $\mathrm{ug} / \mathrm{L}$ & U & \\
\hline 699-S30-E11A & 1,1-Dichloroethene & 8260_VOA_GCMS & 6/14/1999 11:20 AM & 0.15 & ug/L & $U$ & \\
\hline 699-S30-E11A & 1,1-Dichloroethene & 8260_VOA_GCMS & 10/11/2000 1:08 PM & 0.23 & ug/L & $U$ & \\
\hline 699-S30-E11A & 1,1-Dichloroethene & 8260_VOA_GCMS & 7/25/2002 12:03 PM & 0.39 & ug/L & $U$ & \\
\hline 699-S30-E11A & 1,1-Dichloroethene & 8260_VOA_GCMS & 9/10/2003 11:31 AM & 0.16 & ug/L & $U$ & \\
\hline 699-S30-E11A & 1,1-Dichloroethene & 8260_VOA_GCMS & $7 / 14 / 2004$ 11:55 AM & 0.07 & ug/L & $U$ & \\
\hline 699-S30-E11A & 1,1-Dichloroethene & 8260_VOA_GCMS & 9/29/2005 11:50 AM & 0.04 & ug/L & U & \\
\hline 699-S30-E11A & 1,1-Dichloroethene & 8260_VOA_GCMS & 11/6/2006 2:22 PM & 0.21 & ug/L & $\mathrm{U}$ & \\
\hline 699-S31-E10A & 1,1-Dichloroethene & CLP_VOA_GCMS & 2/14/1990 4:01 PM & & ug/L & $U$ & \\
\hline 699-S31-E10A & 1,1-Dichloroethene & CLP_VOA_GCMS & 5/15/1990 10:06 AM & 1 & ug/L & $\mathrm{U}$ & \\
\hline 699-S31-E10A & 1,1-Dichloroethene & CLP_VOA_GCMS & 5/15/1990 10:06 AM & & ug/L & $\mathrm{U}$ & \\
\hline 699-S31-E10A & 1,1-Dichloroethene & CLP_VOA_GCMS & 8/28/1990 9:00 AM & & ug/L & $U$ & \\
\hline 699-S31-E10A & 1,1-Dichloroethene & CLP_VOA_GCMS & 8/28/1990 9:00 AM & & ug/L & $\mathrm{U}$ & \\
\hline 699-S31-E10A & 1,1-Dichloroethene & CLP_VOA_GCMS & 11/26/1990 11:58 AM & & ug/L & $U$ & \\
\hline 699-S31-E10A & 1,1-Dichloroethene & CLP_VOA_GCMS & 3/15/1991 11:03 AM & 5 & ug/L & $U$ & \\
\hline 699-S31-E10A & 1,1-Dichloroethene & CLP_VOA_GCMS & 6/4/1991 9:02 AM & 5 & ug/L & $U$ & \\
\hline 699-S31-E10A & 1,1-Dichloroethene & CLP_VOA_GCMS & 8/12/1991 8:20 AM & & ug/L & U & \\
\hline 699-S31-E10A & 1,1-Dichloroethene & CLP_VOA_GCMS & 9/16/1991 11:01 AM & 5 & ug/L & $\mathrm{U}$ & \\
\hline 699-S31-E10A & 1,1-Dichloroethene & CLP_VOA_GCMS & 11/12/1991 8:38 AM & 5 & ug/L & $\mathrm{U}$ & \\
\hline 699-S31-E10A & 1,1-Dichloroethene & 8240_VOA_GCMS & 3/10/1992 9:18 AM & 0.5 & ug/L & U & \\
\hline 699-S31-E10A & 1,1-Dichloroethene & CLP_VOA_GCMS & 3/10/1992 9:54 AM & 10 & ug/L & U & \\
\hline 699-S31-E10A & 1,1-Dichloroethene & 8240_VOA_GCMS & 3/10/1992 10:11 AM & 2 & ug/L & $\mathrm{U}$ & \\
\hline 699-S31-E10A & 1,1-Dichloroethene & 8240_VOA_GCMS & 5/11/1992 12:00 AM & 2 & ug/L & $U$ & \\
\hline 699-S31-E10A & 1,1-Dichloroethene & 8260_VOA_GCMS & 5/11/1992 12:03 PM & 0.5 & ug/L & $U$ & \\
\hline 699-S31-E10A & 1,1-Dichloroethene & 8260_VOA_GCMS & 5/11/1992 12:03 PM & 0.5 & ug/L & U & \\
\hline 699-S31-E10A & 1,1-Dichloroethene & 8260_VOA_GCMS & 9/14/1992 1:00 PM & 0.5 & ug/L & $U$ & \\
\hline 699-S31-E10A & 1,1-Dichloroethene & 8260_VOA_GCMS & 9/14/1992 1:00 PM & 0.5 & ug/L & $\mathrm{U}$ & \\
\hline 699-S31-E10A & 1,1-Dichloroethene & 8240_VOA_GCMS & 12/8/1992 10:00 AM & 10 & $u g / L$ & $U$ & \\
\hline 699-S31-E10A & 1,1-Dichloroethene & 8240_VOA_GCMS & 3/16/1993 8:56 AM & 10 & ug/L & $U$ & \\
\hline 699-S31-E10A & 1,1-Dichloroethene & 8240_VOA_GCMS & 3/16/1993 9:10 AM & 10 & ug/L & $\mathrm{U}$ & \\
\hline 699-S31-E10A & 1,1-Dichloroethene & 8260_VOA_GCMS & 6/8/1993 9:32 AM & 10 & $\mathrm{ug} / \mathrm{L}$ & $\mathrm{U}$ & \\
\hline 699-S31-E10A & 1,1-Dichloroethene & 8260_VOA_GCMS & 6/8/1993 9:32 AM & 5 & ug/L & $\mathrm{U}$ & \\
\hline 699-S31-E10A & 1,1-Dichloroethene & 8240_VOA_GCMS & 9/22/1993 10:00 AM & 5 & ug/L & $U$ & \\
\hline 699-S31-E10A & 1,1-Dichloroethene & 8240_VOA_GCMS & 9/22/1993 10:00 AM & 10 & ug/L & $\mathrm{U}$ & \\
\hline 699-S31-E10A & 1,1-Dichloroethene & 8260_VOA_GCMS & 11/30/1993 10:40 AM & 5 & $\mathrm{ug} / \mathrm{L}$ & U & \\
\hline 699-S31-E10A & 1,1-Dichloroethene & 8260_VOA_GCMS & 11/30/1993 10:40 AM & 1 & ug/L & & \\
\hline 699-S31-E10A & 1,1-Dichloroethene & 8260_VOA_GCMS & 3/22/1994 9:50 AM & 0.6 & ug/L & $\mathrm{U}$ & \\
\hline 699-S31-E10A & 1,1-Dichloroethene & 8260_VOA_GCMS & 3/22/1994 9:50 AM & 1 & ug/L & U & \\
\hline 699-S31-E10A & 1,1-Dichloroethene & 8260_VOA_GCMS & 6/7/1994 9:46 AM & 0.6 & ug/L & $U$ & \\
\hline 699-S31-E10A & 1,1-Dichloroethene & 8260_VOA_GCMS & 10/12/1994 10:15 AM & 1 & $u g / L$ & U & \\
\hline 699-S31-E10A & 1,1-Dichloroethene & 8260_VOA_GCMS & 4/12/1995 9:30 AM & 3 & $\mathrm{ug} / \mathrm{L}$ & $U$ & \\
\hline 699-S31-E10A & 1,1-Dichloroethene & 8260_VOA_GCMS & 4/12/1995 9:30 AM & 2.6 & ug/L & $\mathrm{J}$ & \\
\hline 699-S31-E10A & 1,1-Dichloroethene & 8240_VOA_GCMS & 5/22/1996 11:17 AM & 5 & ug/L & U & \\
\hline 699-S31-E10A & 1,1-Dichloroethene & 8260_VOA_GCMS & 5/22/1997 12:07 PM & 1 & ug/L & $\mathrm{U}$ & \\
\hline 699-S31-E10A & 1,1-Dichloroethene & 8260_VOA_GCMS & 6/22/1998 10:37 AM & 0.19 & $\mathrm{ug} / \mathrm{L}$ & U & \\
\hline 699-S31-E10A & 1,1-Dichloroethene & 8260_VOA_GCMS & 6/14/1999 11:48 AM & 0.15 & ug/L & $\mathrm{U}$ & \\
\hline 699-S31-E10A & 1,1-Dichloroethene & 8260_VOA_GCMS & 10/11/2000 11:21 AM & 0.23 & ug/L & $U$ & \\
\hline 699-S31-E10A & 1,1-Dichloroethene & 8260_VOA_GCMS & 7/26/2002 12:24 PM & 0.39 & $\mathrm{ug} / \mathrm{L}$ & U & \\
\hline 699-S31-E10A & 1,1-Dichloroethene & 8260_VOA_GCMS & $7 / 22 / 2003$ 10:16 AM & 0.16 & ug/L & U & \\
\hline 699-S31-E10A & 1,1-Dichloroethene & 8260_VOA_GCMS & 7/14/2004 12:32 PM & 0.07 & ug/L & U & \\
\hline 699-S31-E10A & 1,1-Dichloroethene & 8260_VOA_GCMS & 9/29/2005 9:21 AM & 0.04 & $\mathrm{ug} / \mathrm{L}$ & $\mathrm{U}$ & \\
\hline
\end{tabular}




\begin{tabular}{|c|c|c|c|c|c|c|c|}
\hline Well Name & Constituent & Method Name & Sample Date/Time & Value & Units & $\begin{array}{c}\text { Lab } \\
\text { Qualifier } \\
\end{array}$ & \begin{tabular}{|l|} 
Review \\
Qualifier
\end{tabular} \\
\hline 699-S31-E10A & 1,1-Dichloroethene & 8260_VOA_GCMS & $3 / 29 / 2006$ 12:28 PM & 0.21 & ug/L & $U$ & \\
\hline 699-S31-E10C & 1,1-Dichloroethene & CLP_VOA_GCMS & 2/5/1990 10:58 AM & & ug/L & UJ & \\
\hline 699-S31-E10C & 1,1-Dichloroethene & CLP_VOA_GCMS & 5/15/1990 2:02 PM & & ug/L & $U$ & \\
\hline 699-S31-E10C & 1,1-Dichloroethene & CLP_VOA_GCMS & 8/28/1990 10:18 AM & & $\mathrm{ug} / \mathrm{L}$ & $\mathrm{U}$ & \\
\hline 699-S31-E10C & 1,1-Dichloroethene & CLP_VOA_GCMS & 11/27/1990 12:31 PM & & ug/L & $U$ & \\
\hline 699-S31-E10C & 1,1-Dichloroethene & CLP_VOA_GCMS & 3/15/1991 12:36 PM & & $\mathrm{ug} / \mathrm{L}$ & $U$ & \\
\hline 699-S31-E10C & 1,1-Dichloroethene & CLP_VOA_GCMS & 6/4/1991 12:39 PM & & $\mathrm{ug} / \mathrm{L}$ & U & \\
\hline 699-S31-E10C & 1,1-Dichloroethene & CLP_VOA_GCMS & 8/12/1991 10:05 AM & & ug/L & $U$ & \\
\hline 699-S31-E10C & 1,1-Dichloroethene & CLP_VOA_GCMS & 9/16/1991 9:35 AM & & ug/L & $U$ & \\
\hline 699-S31-E10C & 1,1-Dichloroethene & CLP_VOA_GCMS & 11/12/1991 10:16 AM & & ug/L & $U$ & \\
\hline 699-S31-E10C & 1,1-Dichloroethene & 8240_VOA_GCMS & 3/10/1992 11:36 AM & 5 & $\mathrm{ug} / \mathrm{L}$ & $U$ & \\
\hline 699-S31-E10C & 1,1-Dichloroethene & 8240_VOA_GCMS & 3/10/1992 11:49 AM & 0.5 & $\mathrm{ug} / \mathrm{L}$ & $\mathrm{U}$ & \\
\hline 699-S31-E10C & 1,1-Dichloroethene & 8240_VOA_GCMS & 3/10/1992 11:58 AM & & ug/L & $\mathrm{U}$ & \\
\hline 699-S31-E10C & 1,1-Dichloroethene & 8240_VOA_GCMS & 5/12/1992 12:00 AM & 2 & $u g / L$ & $U$ & \\
\hline 699-S31-E10C & 1,1-Dichloroethene & 8260_VOA_GCMS & 5/12/1992 10:27 AM & 0.5 & $\mathrm{ug} / \mathrm{L}$ & $U$ & \\
\hline 699-S31-E10C & 1,1-Dichloroethene & 8260_VOA_GCMS & 5/12/1992 10:27 AM & 0.5 & ug/L & $\mathrm{U}$ & \\
\hline 699-S31-E10C & 1,1-Dichloroethene & 8260_VOA_GCMS & 9/14/1992 10:55 AM & 0.5 & $\mathrm{ug} / \mathrm{L}$ & $\mathrm{U}$ & \\
\hline 699-S31-E10C & 1,1-Dichloroethene & 8260_VOA_GCMS & 9/14/1992 10:55 AM & 0.5 & $\mathrm{ug} / \mathrm{L}$ & $\mathrm{U}$ & \\
\hline 699-S31-E10C & 1,1-Dichloroethene & 8240_VOA_GCMS & 12/7/1992 9:58 AM & 10 & $\mathrm{ug} / \mathrm{L}$ & U & \\
\hline 699-S31-E10C & 1,1-Dichloroethene & 8240_VOA_GCMS & 3/15/1993 9:53 AM & 10 & $\mathrm{ug} / \mathrm{L}$ & $U$ & \\
\hline 699-S31-E10C & 1,1-Dichloroethene & 8260_VOA_GCMS & 6/9/1993 6:57 AM & 5 & $\mathrm{ug} / \mathrm{L}$ & $U$ & \\
\hline 699-S31-E10C & 1,1-Dichloroethene & 8260_VOA_GCMS & 6/9/1993 10:05 AM & 5 & $\mathrm{ug} / \mathrm{L}$ & U & \\
\hline 699-S31-E10C & 1,1-Dichloroethene & 8240_VOA_GCMS & 9/21/1993 8:30 AM & 5 & $\mathrm{ug} / \mathrm{L}$ & U & \\
\hline 699-S31-E10C & 1,1-Dichloroethene & 8240_VOA_GCMS & 9/21/1993 9:54 AM & 5 & $\mathrm{ug} / \mathrm{L}$ & $\mathrm{U}$ & \\
\hline 699-S31-E10C & 1,1-Dichloroethene & 8260_VOA_GCMS & 11/30/1993 9:40 AM & 1 & ug/L & & \\
\hline 699-S31-E10C & 1,1-Dichloroethene & 8260_VOA_GCMS & 11/30/1993 9:40 AM & 1 & $u g / L$ & & \\
\hline 699-S31-E10C & 1,1-Dichloroethene & 8260_VOA_GCMS & 3/21/1994 10:22 AM & 1 & $\mathrm{ug} / \mathrm{L}$ & U & \\
\hline 699-S31-E10C & 1,1-Dichloroethene & 8260_VOA_GCMS & 3/21/1994 10:22 AM & & $\mathrm{ug} / \mathrm{L}$ & $\mathrm{U}$ & \\
\hline 699-S31-E10C & 1,1-Dichloroethene & 8260_VOA_GCMS & 6/6/1994 9:22 AM & 0.6 & $\mathrm{ug} / \mathrm{L}$ & $U$ & \\
\hline 699-S31-E10C & 1,1-Dichloroethene & 8260_VOA_GCMS & 6/6/1994 9:22 AM & 0.6 & $\mathrm{ug} / \mathrm{L}$ & $U$ & \\
\hline 699-S31-E10C & 1,1-Dichloroethene & 8260_VOA_GCMS & 10/11/1994 11:50 AM & 1 & $\mathrm{ug} / \mathrm{L}$ & U & \\
\hline 699-S31-E10C & 1,1-Dichloroethene & 8260_VOA_GCMS & 10/11/1994 2:00 PM & & $\mathrm{ug} / \mathrm{L}$ & $U$ & \\
\hline 699-S31-E10C & 1,1-Dichloroethene & 8260_VOA_GCMS & 4/11/1995 11:30 AM & 2.6 & $\mathrm{ug} / \mathrm{L}$ & $\mathrm{J}$ & \\
\hline 699-S31-E10C & 1,1-Dichloroethene & 8240_VOA_GCMS & 5/22/1996 12:25 PM & 5 & $\mathrm{ug} / \mathrm{L}$ & $U$ & \\
\hline 699-S31-E10C & 1,1-Dichloroethene & 8260_VOA_GCMS & 5/20/1997 2:35 PM & 1 & $u g / L$ & $U$ & \\
\hline 699-S31-E10C & 1,1-Dichloroethene & 8260_VOA_GCMS & 6/19/1998 10:06 AM & 0.19 & ug/L & $\mathrm{U}$ & \\
\hline 699-S31-E10C & 1,1-Dichloroethene & 8260_VOA_GCMS & 6/14/1999 11:01 AM & 0.15 & $\mathrm{ug} / \mathrm{L}$ & $\mathrm{U}$ & \\
\hline 699-S31-E10C & 1,1-Dichloroethene & 8260_VOA_GCMS & 10/11/2000 10:31 AM & 0.23 & $\mathrm{ug} / \mathrm{L}$ & $\mathrm{U}$ & \\
\hline 699-S31-E10C & 1,1-Dichloroethene & 8260_VOA_GCMS & $7 / 26 / 2002$ 11:45 AM & 0.39 & $\mathrm{ug} / \mathrm{L}$ & U & \\
\hline 699-S31-E10C & 1,1-Dichloroethene & 8260_VOA_GCMS & 7/22/2003 9:21 AM & 0.16 & ug/L & $\mathrm{U}$ & \\
\hline 699-S31-E10C & 1,1-Dichloroethene & 8260_VOA_GCMS & 7/14/2004 10:50 AM & 0.07 & $\mathrm{ug} / \mathrm{L}$ & U & \\
\hline 699-S31-E10C & 1,1-Dichloroethene & 8260_VOA_GCMS & 7/19/2005 11:54 AM & 0.04 & $\mathrm{ug} / \mathrm{L}$ & $\mathrm{U}$ & $G$ \\
\hline 699-S31-E10C & 1,1-Dichloroethene & 8260_VOA_GCMS & 11/18/2005 11:35 AM & 0.04 & ug/L & $\mathrm{U}$ & \\
\hline 699-S31-E10C & 1,1-Dichloroethene & 8260_VOA_GCMS & 11/30/2006 9:24 AM & 0.21 & ug/L & U & \\
\hline 699-S31-E10D & 1,1-Dichloroethene & CLP_VOA_GCMS & $1 / 30 / 199011: 55$ AM & 5 & ug/L & $U$ & \\
\hline 699-S31-E10D & 1,1-Dichloroethene & CLP_VOA_GCMS & 5/16/1990 12:00 PM & 5 & ug/L & $U$ & \\
\hline 699-S31-E10D & 1,1-Dichloroethene & CLP_VOA_GCMS & 5/16/1990 12:00 PM & 1 & ug/L & UJ & \\
\hline 699-S31-E10D & 1,1-Dichloroethene & CLP_VOA_GCMS & 8/28/1990 12:40 PM & 1 & ug/L & $U$ & \\
\hline 699-S31-E10D & 1,1-Dichloroethene & CLP_VOA_GCMS & 11/27/1990 2:18 PM & 3 & ug/L & U & \\
\hline 699-S31-E10D & 1,1-Dichloroethene & CLP_VOA_GCMS & 3/15/1991 2:07 PM & 5 & ug/L & $\mathrm{U}$ & \\
\hline 699-S31-E10D & 1,1-Dichloroethene & CLP_VOA_GCMS & 6/17/1991 10:20 AM & 5 & ug/L & U & \\
\hline 699-S31-E10D & 1,1-Dichloroethene & CLP_VOA_GCMS & 8/12/1991 11:12 AM & 5 & $u g / L$ & $\mathrm{U}$ & \\
\hline 699-S31-E10D & 1,1-Dichloroethene & CLP_VOA_GCMS & 9/16/1991 11:45 AM & & ug/L & $U$ & \\
\hline 699-S31-E10D & 1,1-Dichloroethene & CLP_VOA_GCMS & 11/12/1991 10:53 AM & 5 & ug/L & U & \\
\hline 699-S31-E10D & 1,1-Dichloroethene & 8240_VOA_GCMS & 3/10/1992 1:23 AM & 2 & ug/L & U & \\
\hline 699-S31-E10D & 1,1-Dichloroethene & 8240_VOA_GCMS & 3/10/1992 12:56 PM & 0.5 & ug/L & U & \\
\hline 699-S31-E10D & 1,1-Dichloroethene & 8240_VOA_GCMS & 5/12/1992 12:00 AM & & ug/L & U & \\
\hline
\end{tabular}




\begin{tabular}{|c|c|c|c|c|c|c|c|}
\hline Well Name & Constituent & Method Name & Sample Date/Time & Value & Units & $\begin{array}{c}\text { Lab } \\
\text { Qualifier } \\
\end{array}$ & \begin{tabular}{|l|} 
Review \\
Qualifier
\end{tabular} \\
\hline 699-S31-E10D & 1,1-Dichloroethene & 8260_VOA_GCMS & 5/12/1992 9:28 AM & 0.5 & ug/L & $U$ & \\
\hline 699-S31-E10D & 1,1-Dichloroethene & 8240_VOA_GCMS & 12/7/1992 9:20 AM & 10 & $\mathrm{ug} / \mathrm{L}$ & $U$ & \\
\hline 699-S31-E10D & 1,1-Dichloroethene & 8240_VOA_GCMS & 3/15/1993 9:00 AM & 10 & $\mathrm{ug} / \mathrm{L}$ & $U$ & \\
\hline 699-S31-E10D & 1,1-Dichloroethene & 8260_VOA_GCMS & 6/7/1993 9:22 AM & 5 & $\mathrm{ug} / \mathrm{L}$ & $U$ & \\
\hline 699-S31-E10D & 1,1-Dichloroethene & 8240_VOA_GCMS & 9/21/1993 9:00 AM & & $\mathrm{ug} / \mathrm{L}$ & $U$ & \\
\hline 699-S31-E10D & 1,1-Dichloroethene & 8260_VOA_GCMS & 11/30/1993 9:00 AM & 1 & $\mathrm{ug} / \mathrm{L}$ & & \\
\hline 699-S31-E10D & 1,1-Dichloroethene & 8260_VOA_GCMS & 3/21/1994 9:20 AM & & $\mathrm{ug} / \mathrm{L}$ & $U$ & \\
\hline 699-S31-E10D & 1,1-Dichloroethene & 8260_VOA_GCMS & 6/6/1994 10:50 AM & 0.6 & $\mathrm{ug} / \mathrm{L}$ & $U$ & \\
\hline 699-S31-E10D & 1,1-Dichloroethene & 8260_VOA_GCMS & 10/11/1994 10:50 AM & 1 & $\mathrm{ug} / \mathrm{L}$ & $U$ & \\
\hline 699-S31-E10D & 1,1-Dichloroethene & 8260_VOA_GCMS & 4/11/1995 10:45 AM & 2.6 & ug/L & $\mathrm{J}$ & \\
\hline 699-S31-E10D & 1,1-Dichloroethene & 8240_VOA_GCMS & 5/22/1996 1:04 PM & 5 & $\mathrm{ug} / \mathrm{L}$ & $U$ & \\
\hline 699-S31-E10D & 1,1-Dichloroethene & 8260_VOA_GCMS & 5/20/1997 2:00 PM & 1 & $\mathrm{ug} / \mathrm{L}$ & $U$ & \\
\hline 699-S31-E10D & 1,1-Dichloroethene & 8260_VOA_GCMS & 6/19/1998 9:07 AM & 0.19 & $\mathrm{ug} / \mathrm{L}$ & $U$ & \\
\hline 699-S31-E10D & 1,1-Dichloroethene & 8260_VOA_GCMS & 6/15/1999 10:32 AM & 0.15 & $\mathrm{ug} / \mathrm{L}$ & $U$ & \\
\hline 699-S31-E10D & 1,1-Dichloroethene & 8260_VOA_GCMS & 10/11/2000 9:24 AM & 0.23 & $\mathrm{ug} / \mathrm{L}$ & $U$ & \\
\hline 699-S31-E10D & 1,1-Dichloroethene & 8260_VOA_GCMS & 7/26/2002 10:04 AM & 0.39 & ug/L & $U$ & \\
\hline 699-S31-E10D & 1,1-Dichloroethene & 8260_VOA_GCMS & $7 / 22 / 20038: 33 \mathrm{AM}$ & 0.16 & $\mathrm{ug} / \mathrm{L}$ & $U$ & \\
\hline 699-S31-E10D & 1,1-Dichloroethene & 8260_VOA_GCMS & 7/14/2004 9:18 AM & 0.07 & $\mathrm{ug} / \mathrm{L}$ & $U$ & \\
\hline 699-S31-E10D & 1,1-Dichloroethene & 8260_VOA_GCMS & 9/29/2005 8:44 AM & 0.04 & $\mathrm{ug} / \mathrm{L}$ & $U$ & \\
\hline 699-S31-E10D & 1,1-Dichloroethene & 8260_VOA_GCMS & $3 / 29 / 2006$ 11:51 AM & 0.21 & $u g / L$ & $U$ & \\
\hline 699-S31-E11 & 1,1-Dichloroethene & CLP_VOA_GCMS & 6/27/1991 1:48 PM & 5 & $\mathrm{ug} / \mathrm{L}$ & $U$ & \\
\hline 699-S31-E11 & 1,1-Dichloroethene & CLP_VOA_GCMS & 8/13/1991 10:03 AM & 5 & $\mathrm{ug} / \mathrm{L}$ & $U$ & \\
\hline 699-S31-E11 & 1,1-Dichloroethene & CLP_VOA_GCMS & 9/17/1991 8:17 AM & 5 & $\mathrm{ug} / \mathrm{L}$ & $U$ & \\
\hline 699-S31-E11 & 1,1-Dichloroethene & CLP_VOA_GCMS & 11/14/1991 12:00 AM & 5 & $\mathrm{ug} / \mathrm{L}$ & $U$ & \\
\hline 699-S31-E11 & 1,1-Dichloroethene & 8260_VOA_GCMS & 5/11/1992 12:00 AM & 0.5 & $\mathrm{ug} / \mathrm{L}$ & $U$ & \\
\hline 699-S31-E11 & 1,1-Dichloroethene & 8260_VOA_GCMS & 5/11/1992 12:00 AM & 0.5 & $\mathrm{ug} / \mathrm{L}$ & $U$ & \\
\hline 699-S31-E11 & 1,1-Dichloroethene & 8260_VOA_GCMS & 9/16/1992 10:35 AM & 0.5 & $\mathrm{ug} / \mathrm{L}$ & $U$ & \\
\hline \begin{tabular}{|l}
$699-S 31-E 11$ \\
\end{tabular} & 1,1-Dichloroethene & 8240_VOA_GCMS & 3/17/1993 10:28 AM & 10 & $\mathrm{ug} / \mathrm{L}$ & $U$ & \\
\hline 699-S31-E11 & 1,1-Dichloroethene & 8240_VOA_GCMS & 3/17/1993 10:34 AM & 3 & $\mathrm{ug} / \mathrm{L}$ & $\mathrm{J}$ & \\
\hline 699-S31-E11 & 1,1-Dichloroethene & 8240_VOA_GCMS & 9/23/1993 10:50 AM & 5 & $\mathrm{ug} / \mathrm{L}$ & $U$ & \\
\hline 699-S31-E11 & 1,1-Dichloroethene & 8260_VOA_GCMS & 12/1/1993 10:50 AM & 1 & $\mathrm{ug} / \mathrm{L}$ & U & \\
\hline 699-S31-E11 & 1,1-Dichloroethene & 8260_VOA_GCMS & 4/10/1995 10:00 AM & 2.6 & $\mathrm{ug} / \mathrm{L}$ & UJ & \\
\hline 699-S31-E11 & 1,1-Dichloroethene & 8240_VOA_GCMS & 5/24/1996 10:15 AM & 5 & $\mathrm{ug} / \mathrm{L}$ & $\mathrm{U}$ & \\
\hline 699-S31-E11 & 1,1-Dichloroethene & 8260_VOA_GCMS & 5/22/1997 8:09 AM & 1 & $\mathrm{ug} / \mathrm{L}$ & $U$ & \\
\hline 699-S31-E11 & 1,1-Dichloroethene & 8260_VOA_GCMS & 6/19/1998 7:41 AM & 0.17 & ug/L & $U$ & \\
\hline 699-S31-E11 & 1,1-Dichloroethene & 8260_VOA_GCMS & 6/19/1998 7:41 AM & 0.19 & ug/L & $U$ & \\
\hline 699-S31-E11 & 1,1-Dichloroethene & 8260_VOA_GCMS & 6/15/1999 9:49 AM & 0.15 & $\mathrm{ug} / \mathrm{L}$ & $U$ & \\
\hline \begin{tabular}{|l|}
$699-S 31-E 11$ \\
\end{tabular} & 1,1-Dichloroethene & 8260_VOA_GCMS & 10/12/2000 12:02 PM & 0.23 & $\mathrm{ug} / \mathrm{L}$ & $U$ & \\
\hline 699-S31-E11 & 1,1-Dichloroethene & 8260_VOA_GCMS & $7 / 25 / 2002$ 11:38 AM & 0.39 & $\mathrm{ug} / \mathrm{L}$ & $U$ & \\
\hline 699-S31-E11 & 1,1-Dichloroethene & 8260_VOA_GCMS & $7 / 31 / 2003$ 11:12 AM & 0.16 & ug/L & $U$ & \\
\hline 699-S31-E11 & 1,1-Dichloroethene & 8260_VOA_GCMS & 7/15/2004 12:04 PM & 0.07 & $\mathrm{ug} / \mathrm{L}$ & $U$ & \\
\hline 699-S31-E11 & 1,1-Dichloroethene & 8260_VOA_GCMS & 9/29/2005 10:42 AM & 0.04 & $\mathrm{ug} / \mathrm{L}$ & $U$ & \\
\hline \begin{tabular}{|l}
$699-S 31-E 11$ \\
\end{tabular} & 1,1-Dichloroethene & 8260_VOA_GCMS & $3 / 29 / 2006$ 10:57 AM & 0.21 & ug/L & $U$ & \\
\hline 699-S27-E12A & Trichloroethene & 8240_VOA_GCMS & 5/20/1996 10:10 AM & 6 & $u g / L$ & & \\
\hline 699-S27-E12A & Trichloroethene & 8260_VOA_GCMS & 5/22/1997 10:24 AM & 5 & ug/L & & \\
\hline 699-S27-E12A & Trichloroethene & 8260_VOA_GCMS & 5/22/1997 10:24 AM & 5 & ug/L & & \\
\hline 699-S27-E12A & Trichloroethene & 8260_VOA_GCMS & 6/22/1998 1:28 PM & $\underline{6}$ & ug/L & & \\
\hline 699-S27-E12A & Trichloroethene & 8260_VOA_GCMS & 6/22/1998 1:28 PM & 6 & ug/L & & \\
\hline 699-S27-E12A & Trichloroethene & 8260_VOA_GCMS & 6/14/1999 10:07 AM & 3 & $\mathrm{ug} / \mathrm{L}$ & $\mathrm{J}$ & \\
\hline 699-S27-E12A & Trichloroethene & 8260_VOA_GCMS & 10/11/2000 10:05 AM & 2.5 & ug/L & & \\
\hline 699-S27-E12A & Trichloroethene & 8260_VOA_GCMS & 4/30/2001 1:16 PM & 2.6 & ug/L & $\mathrm{J}$ & \\
\hline 699-S27-E12A & Trichloroethene & 8260_VOA_GCMS & $7 / 25 / 2002$ 10:36 AM & 2.1 & ug/L & $\mathrm{J}$ & \\
\hline 699-S27-E12A & Trichloroethene & 8260_VOA_GCMS & 7/21/2003 12:52 PM & 1.9 & ug/L & & \\
\hline 699-S27-E12A & Trichloroethene & 8260_VOA_GCMS & $7 / 14 / 2004$ 11:01 AM & 1.6 & ug/L & & \\
\hline 699-S27-E12A & Trichloroethene & 8260_VOA_GCMS & 9/29/2005 9:55 AM & 1 & ug/L & & \\
\hline 699-S27-E12A & Trichloroethene & 8260_VOA_GCMS & 11/6/2006 12:12 PM & 1.2 & ug/L & & \\
\hline 699-S28-E12 & Trichloroethene & CLP_VOA_GCMS & 6/17/1991 11:30 AM & & ug/L & $U$ & \\
\hline
\end{tabular}




\begin{tabular}{|c|c|c|c|c|c|c|c|}
\hline Well Name & Constituent & Method Name & Sample Date/Time & Value & Units & \begin{tabular}{|c|} 
Lab \\
Qualifier \\
\end{tabular} & $\begin{array}{c}\text { Review } \\
\text { Qualifier } \\
\end{array}$ \\
\hline 699-S28-E12 & Trichloroethene & CLP_VOA_GCMS & 8/16/1991 8:50 AM & 5 & $\mathrm{ug} / \mathrm{L}$ & \begin{tabular}{|l|}
$U$ \\
\end{tabular} & \\
\hline 699-S28-E12 & Trichloroethene & CLP_VOA_GCMS & 9/19/1991 7:35 AM & 5 & ug/L & $\mathrm{U}$ & \\
\hline 699-S28-E12 & Trichloroethene & CLP_VOA_GCMS & 12/5/1991 12:00 AM & 5 & ug/L & $\mathrm{U}$ & \\
\hline 699-S28-E12 & Trichloroethene & CLP_VOA_GCMS & 4/21/1992 12:00 AM & 10 & ug/L & $\mathrm{U}$ & \\
\hline 699-S28-E12 & Trichloroethene & CLP_VOA_GCMS & 9/9/1992 12:00 AM & 10 & ug/L & $\mathrm{U}$ & \\
\hline 699-S28-E12 & Trichloroethene & CLP_VOA_GCMS & 3/12/1993 9:20 AM & 1 & ug/L & $\mathrm{J}$ & \\
\hline 699-S28-E12 & Trichloroethene & 502.2_VOA_GC & 7/30/1993 9:30 AM & 1.4 & ug/L & & \\
\hline 699-S28-E12 & Trichloroethene & 502.2_VOA_GC & 5/10/1994 8:30 AM & 2.3 & ug/L & & \\
\hline 699-S28-E12 & Trichloroethene & 502.2_VOA_GC & 10/17/1994 8:50 AM & 0.5 & ug/L & $\mathrm{U}$ & \\
\hline 699-S28-E12 & Trichloroethene & 502.2_VOA_GC & 1/26/1995 8:40 AM & 4.8 & ug/L & & \\
\hline 699-S28-E12 & Trichloroethene & 8010_VOA_GC & 1/26/1995 8:40 AM & 2.9 & ug/L & & \\
\hline 699-S28-E12 & Trichloroethene & 8010_VOA_GC & 1/17/1996 10:50 AM & 3.9 & ug/L & & \\
\hline 699-S28-E12 & Trichloroethene & 8260_VOA_GCMS & 5/22/1997 12:55 PM & 5 & ug/L & & \\
\hline 699-S28-E12 & Trichloroethene & 8260_VOA_GCMS & 6/19/1998 8:25 AM & 6 & ug/L & & \\
\hline 699-S28-E12 & Trichloroethene & 8260_VOA_GCMS & 6/30/1998 7:52 AM & 7 & ug/L & & \\
\hline 699-S28-E12 & Trichloroethene & 8260_VOA_GCMS & 6/14/1999 8:50 AM & 4 & ug/L & $\mathrm{J}$ & \\
\hline 699-S28-E12 & Trichloroethene & 8260_VOA_GCMS & 10/11/2000 9:23 AM & 3.4 & ug/L & & \\
\hline 699-S28-E12 & Trichloroethene & 8260_VOA_GCMS & 5/2/2001 11:53 AM & 2.9 & ug/L & $\mathrm{J}$ & \\
\hline 699-S28-E12 & Trichloroethene & 8260_VOA_GCMS & 7/25/2002 8:53 AM & 3.5 & ug/L & $\mathrm{J}$ & \\
\hline 699-S28-E12 & Trichloroethene & 8260_VOA_GCMS & $7 / 25 / 20028: 53 \mathrm{AM}$ & 3.5 & ug/L & $\mathrm{J}$ & \\
\hline 699-S28-E12 & Trichloroethene & 8260_VOA_GCMS & 9/10/2003 10:21 AM & 2.6 & ug/L & & \\
\hline 699-S28-E12 & Trichloroethene & 8260_VOA_GCMS & $7 / 13 / 2004$ 11:46 AM & 1.7 & ug/L & & \\
\hline 699-S28-E12 & Trichloroethene & 8260_VOA_GCMS & 7/14/2005 10:59 AM & 1.9 & ug/L & $\mathrm{B}$ & \\
\hline 699-S28-E12 & Trichloroethene & 8260_VOA_GCMS & 11/6/2006 12:50 PM & 1.7 & ug/L & & \\
\hline 699-S28-E13A & Trichloroethene & 8240_VOA_GCMS & 5/21/1996 12:36 PM & 5 & ug/L & $\mathrm{U}$ & \\
\hline 699-S28-E13A & Trichloroethene & 8260_VOA_GCMS & 5/22/1997 11:53 AM & 1 & ug/L & & \\
\hline 699-S28-E13A & Trichloroethene & 8260_VOA_GCMS & 6/19/1998 1:17 PM & 2 & ug/L & $\mathrm{J}$ & \\
\hline 699-S28-E13A & Trichloroethene & 8260_VOA_GCMS & 6/14/1999 9:26 AM & 0.8 & ug/L & $\mathrm{J}$ & \\
\hline 699-S28-E13A & Trichloroethene & 8260_VOA_GCMS & 10/11/2000 11:19 AM & 0.89 & ug/L & $\mathrm{J}$ & \\
\hline 699-S28-E13A & Trichloroethene & 8260_VOA_GCMS & 4/30/2001 12:04 PM & 0.85 & ug/L & $\mathrm{J}$ & \\
\hline 699-S28-E13A & Trichloroethene & 8260_VOA_GCMS & $7 / 25 / 2002$ 10:54 AM & 0.52 & ug/L & $\mathrm{J}$ & \\
\hline 699-S28-E13A & Trichloroethene & 8260_VOA_GCMS & $7 / 17 / 2003$ 11:20 AM & 0.55 & ug/L & $\mathrm{J}$ & \\
\hline 699-S28-E13A & Trichloroethene & 8260_VOA_GCMS & $7 / 13 / 2004$ 10:57 AM & 0.43 & ug/L & $\mathrm{J}$ & \\
\hline 699-S28-E13A & Trichloroethene & 8260_VOA_GCMS & 9/29/2005 9:08 AM & 0.13 & ug/L & $\mathrm{U}$ & \\
\hline 699-S28-E13A & Trichloroethene & 8260_VOA_GCMS & 8/31/2006 11:20 AM & 0.4 & ug/L & $\mathrm{J}$ & \\
\hline 699-S29-E10A & Trichloroethene & 8240_VOA_GCMS & 5/20/1996 11:04 AM & 5 & ug/L & $\mathrm{U}$ & \\
\hline 699-S29-E10A & Trichloroethene & 8260_VOA_GCMS & 5/22/1997 9:44 AM & 0.5 & ug/L & $\mathrm{J}$ & \\
\hline 699-S29-E10A & Trichloroethene & 8260_VOA_GCMS & 6/22/1998 12:39 PM & 0.5 & ug/L & $\mathrm{J}$ & \\
\hline 699-S29-E10A & Trichloroethene & 8260_VOA_GCMS & 6/14/1999 10:44 AM & 0.16 & ug/L & $\mathrm{U}$ & \\
\hline 699-S29-E10A & Trichloroethene & 8260_VOA_GCMS & 10/11/2000 8:00 AM & 0.22 & ug/L & $\mathrm{J}$ & \\
\hline 699-S29-E10A & Trichloroethene & 8260_VOA_GCMS & 5/2/2001 9:05 AM & 0.16 & ug/L & $\mathrm{U}$ & \\
\hline 699-S29-E10A & Trichloroethene & 8260_VOA_GCMS & 5/2/2001 9:05 AM & 0.16 & ug/L & $\mathrm{U}$ & \\
\hline 699-S29-E10A & Trichloroethene & 8260_VOA_GCMS & $7 / 25 / 2002$ 11:35 AM & 0.29 & ug/L & $\mathrm{U}$ & \\
\hline 699-S29-E10A & Trichloroethene & 8260_VOA_GCMS & 7/17/2003 1:08 PM & 0.16 & ug/L & $\mathrm{U}$ & \\
\hline 699-S29-E10A & Trichloroethene & 8260_VOA_GCMS & $7 / 13 / 2004$ 12:28 PM & 0.09 & ug/L & $\mathrm{U}$ & \\
\hline 699-S29-E10A & Trichloroethene & 8260_VOA_GCMS & 9/29/2005 11:23 AM & 0.13 & ug/L & $\mathrm{U}$ & \\
\hline 699-S29-E10A & Trichloroethene & 8260_VOA_GCMS & 11/30/2006 11:10 AM & 0.2 & ug/L & $\mathrm{U}$ & \\
\hline 699-S29-E11 & Trichloroethene & CLP_VOA_GCMS & 6/27/1991 12:45 PM & 3 & ug/L & $\mathrm{J}$ & \\
\hline 699-S29-E11 & Trichloroethene & CLP_VOA_GCMS & 8/13/1991 11:11 AM & 2 & ug/L & $\mathrm{J}$ & \\
\hline 699-S29-E11 & Trichloroethene & CLP_VOA_GCMS & 9/17/1991 10:55 AM & 3 & ug/L & $\mathrm{J}$ & \\
\hline 699-S29-E11 & Trichloroethene & CLP_VOA_GCMS & 11/21/1991 10:17 AM & 4 & ug/L & $\mathrm{J}$ & \\
\hline 699-S29-E11 & Trichloroethene & 8260_VOA_GCMS & 9/16/1992 9:35 AM & 5 & ug/L & & \\
\hline 699-S29-E11 & Trichloroethene & 8240_VOA_GCMS & 12/9/1992 10:02 AM & 8 & ug/L & $\mathrm{J}$ & \\
\hline 699-S29-E11 & Trichloroethene & 8240_VOA_GCMS & 3/17/1993 11:23 AM & 10 & ug/L & & \\
\hline 699-S29-E11 & Trichloroethene & 8260_VOA_GCMS & 6/9/1993 6:16 AM & 10 & ug/L & & \\
\hline 699-S29-E11 & Trichloroethene & 8240_VOA_GCMS & 9/22/1993 12:00 PM & 16 & ug/L & $\mathrm{U}$ & \\
\hline 699-S29-E11 & Trichloroethene & 8260_VOA_GCMS & 12/1/1993 11:40 AM & 15 & ug/L & & \\
\hline
\end{tabular}




\begin{tabular}{|c|c|c|c|c|c|c|c|}
\hline Well Name & Constituent & Method Name & Sample Date/Time & Value & Units & $\begin{array}{c}\text { Lab } \\
\text { Qualifier }\end{array}$ & $\begin{array}{l}\text { Review } \\
\text { Qualifier }\end{array}$ \\
\hline 699-S29-E11 & Trichloroethene & 8260_VOA_GCMS & 3/23/1994 9:07 AM & 12 & ug/L & $U$ & \\
\hline 699-S29-E11 & Trichloroethene & 8260_VOA_GCMS & 10/11/1994 9:11 AM & 1 & ug/L & $\mathrm{U}$ & \\
\hline 699-S29-E11 & Trichloroethene & 8260_VOA_GCMS & 10/11/1994 9:45 AM & 14 & $\mathrm{ug} / \mathrm{L}$ & & \\
\hline 699-S29-E11 & Trichloroethene & 502.2_VOA_GC & 10/18/1994 12:01 PM & 18 & $\mathrm{ug} / \mathrm{L}$ & & \\
\hline 699-S29-E11 & Trichloroethene & 8260_VOA_GCMS & 4/10/1995 11:00 AM & 13 & ug/L & & \\
\hline 699-S29-E11 & Trichloroethene & 8010_VOA_GC & 8/4/1995 12:45 PM & 12 & $u g / L$ & & \\
\hline 699-S29-E11 & Trichloroethene & 8010_VOA_GC & 3/4/1996 9:05 AM & 7.4 & ug/L & & \\
\hline 699-S29-E11 & Trichloroethene & 8240_VOA_GCMS & 5/24/1996 12:15 PM & 9 & $\mathrm{ug} / \mathrm{L}$ & & \\
\hline 699-S29-E11 & Trichloroethene & 8010_VOA_GC & 1/20/1997 10:54 AM & 7.8 & ug/L & & \\
\hline 699-S29-E11 & Trichloroethene & 8260_VOA_GCMS & 1/19/1998 9:22 AM & 6 & ug/L & & \\
\hline 699-S29-E11 & Trichloroethene & 8260_VOA_GCMS & 1/20/1999 11:38 AM & 0.12 & ug/L & $U$ & \\
\hline 699-S29-E11 & Trichloroethene & 8260_VOA_GCMS & 5/2/2001 12:51 PM & 3.1 & $u g / L$ & $\mathrm{~J}$ & \\
\hline 699-S29-E11 & Trichloroethene & 8260_VOA_GCMS & 7/25/2002 12:16 PM & 3.1 & ug/L & $\mathrm{J}$ & \\
\hline 699-S29-E11 & Trichloroethene & 8260_VOA_GCMS & 7/25/2002 12:16 PM & 3 & ug/L & $\mathrm{J}$ & \\
\hline 699-S29-E11 & Trichloroethene & 8260_VOA_GCMS & 7/17/2003 12:24 PM & 2.3 & ug/L & & \\
\hline 699-S29-E11 & Trichloroethene & 8260_VOA_GCMS & $7 / 13 / 2004$ 11:45 AM & 1.7 & ug/L & & \\
\hline 699-S29-E11 & Trichloroethene & 8260_VOA_GCMS & $7 / 14 / 200511: 54 \mathrm{AM}$ & 1.6 & ug/L & $B$ & \\
\hline 699-S29-E11 & Trichloroethene & 8260_VOA_GCMS & 12/27/2006 1:20 PM & 2 & ug/L & & \\
\hline 699-S29-E12 & Trichloroethene & 8240_VOA_GCMS & 1/17/1989 12:00 AM & 5 & ug/L & U & \\
\hline 699-S29-E12 & Trichloroethene & 8240_VOA_GCMS & 5/24/1989 12:00 AM & 5 & ug/L & $U$ & \\
\hline 699-S29-E12 & Trichloroethene & CLP_VOA_GCMS & 5/23/1990 9:08 AM & 1 & ug/L & $U$ & \\
\hline 699-S29-E12 & Trichloroethene & CLP_VOA_GCMS & 8/22/1990 1:38 PM & 1 & ug/L & $U$ & \\
\hline 699-S29-E12 & Trichloroethene & CLP_VOA_GCMS & 11/29/1990 10:25 AM & & ug/L & U & \\
\hline 699-S29-E12 & Trichloroethene & CLP_VOA_GCMS & 6/6/1991 1:31 PM & 5 & ug/L & $\mathrm{U}$ & \\
\hline 699-S29-E12 & Trichloroethene & CLP_VOA_GCMS & 11/18/1991 12:55 PM & 5 & ug/L & $\mathrm{U}$ & \\
\hline 699-S29-E12 & Trichloroethene & 502.2_VOA_GC & 5/8/1992 10:44 AM & 0.4 & ug/L & $\mathrm{J}$ & \\
\hline 699-S29-E12 & Trichloroethene & 8260_VOA_GCMS & 5/14/1992 9:19 AM & 0.5 & $\mathrm{ug} / \mathrm{L}$ & U & \\
\hline 699-S29-E12 & Trichloroethene & 8260_VOA_GCMS & 9/15/1992 5:40 AM & 0.5 & ug/L & $\mathrm{U}$ & \\
\hline 699-S29-E12 & Trichloroethene & 8240_VOA_GCMS & 12/9/1992 10:58 AM & 1 & ug/L & $U$ & \\
\hline 699-S29-E12 & Trichloroethene & 8240_VOA_GCMS & 3/17/1993 9:31 AM & 10 & $u g / L$ & $U$ & \\
\hline 699-S29-E12 & Trichloroethene & 8260_VOA_GCMS & 6/9/1993 5:25 AM & 5 & ug/L & U & \\
\hline 699-S29-E12 & Trichloroethene & 502.2_VOA_GC & 8/24/1993 12:46 PM & 0.5 & ug/L & $U$ & \\
\hline 699-S29-E12 & Trichloroethene & 8240_VOA_GCMS & 9/22/1993 9:00 AM & 5 & ug/L & UJ & \\
\hline 699-S29-E12 & Trichloroethene & 8260_VOA_GCMS & 12/1/1993 9:30 AM & 1 & ug/L & $U$ & \\
\hline 699-S29-E12 & Trichloroethene & 8260_VOA_GCMS & 3/22/1994 12:45 PM & 1 & ug/L & $U$ & \\
\hline 699-S29-E12 & Trichloroethene & 502.2_VOA_GC & 5/11/1994 8:30 AM & 0.5 & ug/L & $\mathrm{U}$ & \\
\hline 699-S29-E12 & Trichloroethene & 8260_VOA_GCMS & 6/8/1994 10:40 AM & 0.5 & $\mathrm{ug} / \mathrm{L}$ & $\mathrm{U}$ & \\
\hline 699-S29-E12 & Trichloroethene & 8260_VOA_GCMS & 10/12/1994 12:15 PM & 1 & ug/L & $\mathrm{U}$ & \\
\hline 699-S29-E12 & Trichloroethene & 502.2_VOA_GC & 1/18/1995 8:00 AM & 0.5 & ug/L & $U$ & \\
\hline 699-S29-E12 & Trichloroethene & 8260_VOA_GCMS & 4/11/1995 12:00 PM & 28 & ug/L & & \\
\hline 699-S29-E12 & Trichloroethene & 8260_VOA_GCMS & 4/11/1995 1:15 PM & 2.4 & $\mathrm{ug} / \mathrm{L}$ & U & \\
\hline 699-S29-E12 & Trichloroethene & 8010_VOA_GC & 1/15/1996 9:10 AM & 0.075 & ug/L & $\mathrm{U}$ & \\
\hline \begin{tabular}{|l|}
$699-S 29-E 12$ \\
\end{tabular} & Trichloroethene & 8240_VOA_GCMS & 5/20/1996 12:47 PM & 5 & ug/L & $\mathrm{U}$ & \\
\hline 699-S29-E12 & Trichloroethene & 8010_VOA_GC & 1/16/1997 9:20 AM & 0.8 & ug/L & & \\
\hline 699-S29-E12 & Trichloroethene & 8010_VOA_GC & 1/16/1997 9:20 AM & 0.8 & ug/L & & \\
\hline 699-S29-E12 & Trichloroethene & 8260_VOA_GCMS & 1/12/1998 12:23 PM & 2 & ug/L & $\mathrm{J}$ & \\
\hline 699-S29-E12 & Trichloroethene & 8260_VOA_GCMS & 1/20/1999 9:17 AM & 1 & ug/L & $\mathrm{J}$ & \\
\hline 699-S29-E12 & Trichloroethene & 8260_VOA_GCMS & $7 / 25 / 2002$ 9:45 AM & 0.29 & ug/L & $U$ & \\
\hline 699-S29-E12 & Trichloroethene & 8260_VOA_GCMS & $7 / 21 / 2003$ 12:10 PM & 0.23 & $\mathrm{ug} / \mathrm{L}$ & $\mathrm{J}$ & \\
\hline 699-S29-E12 & Trichloroethene & 8260_VOA_GCMS & 7/13/2004 10:01 AM & 0.38 & ug/L & $\mathrm{J}$ & \\
\hline 699-S29-E12 & Trichloroethene & 8260_VOA_GCMS & 11/18/2005 10:51 AM & 0.26 & ug/L & $\mathrm{J}$ & \\
\hline 699-S29-E12 & Trichloroethene & 8260_VOA_GCMS & 11/6/2006 1:32 PM & 0.62 & ug/L & $\mathrm{J}$ & \\
\hline 699-S29-E13A & Trichloroethene & 8240_VOA_GCMS & 5/24/1996 12:00 AM & 5 & ug/L & $U$ & \\
\hline 699-S29-E13A & Trichloroethene & 8260_VOA_GCMS & 5/22/1997 11:18 AM & 1 & ug/L & U & \\
\hline 699-S29-E13A & Trichloroethene & 8260_VOA_GCMS & 6/24/1998 8:37 AM & 0.4 & ug/L & U & \\
\hline 699-S29-E13A & Trichloroethene & 8260_VOA_GCMS & 6/15/1999 8:27 AM & 0.16 & ug/L & U & \\
\hline 699-S29-E13A & Trichloroethene & 8260_VOA_GCMS & 6/15/1999 8:27 AM & 0.16 & $\mathrm{ug} / \mathrm{L}$ & $\mathrm{U}$ & \\
\hline
\end{tabular}




\begin{tabular}{|c|c|c|c|c|c|c|c|}
\hline Well Name & Constituent & Method Name & Sample Date/Time & Value & Units & \begin{tabular}{|c|} 
Lab \\
Qualifier \\
\end{tabular} & $\begin{array}{l}\text { Review } \\
\text { Qualifier } \\
\end{array}$ \\
\hline 699-S29-E13A & Trichloroethene & 8260_VOA_GCMS & 10/11/2000 12:38 PM & 0.16 & ug/L & $U$ & \\
\hline 699-S29-E13A & Trichloroethene & 8260_VOA_GCMS & 10/11/2000 12:38 PM & 0.16 & ug/L & $U$ & \\
\hline 699-S29-E13A & Trichloroethene & 8260_VOA_GCMS & 5/2/2001 10:46 AM & 0.16 & $\mathrm{ug} / \mathrm{L}$ & $\mathrm{U}$ & \\
\hline 699-S29-E13A & Trichloroethene & 8260_VOA_GCMS & 7/25/2002 10:17 AM & 0.29 & $\mathrm{ug} / \mathrm{L}$ & $U$ & \\
\hline 699-S29-E13A & Trichloroethene & 8260_VOA_GCMS & 7/22/2003 12:34 PM & 0.16 & $\mathrm{ug} / \mathrm{L}$ & $U$ & \\
\hline 699-S29-E13A & Trichloroethene & 8260_VOA_GCMS & $7 / 14 / 2004$ 11:47 AM & 0.09 & ug/L & U & \\
\hline 699-S29-E13A & Trichloroethene & 8260_VOA_GCMS & 9/29/2005 12:40 PM & 0.13 & $\mathrm{ug} / \mathrm{L}$ & U & \\
\hline 699-S29-E13A & Trichloroethene & 8260_VOA_GCMS & 11/6/2006 11:18 AM & 0.2 & ug/L & $U$ & \\
\hline 699-S30-E10A & Trichloroethene & CLP_VOA_GCMS & 2/6/1990 10:06 AM & 0.6 & $\mathrm{ug} / \mathrm{L}$ & $\mathrm{J}$ & \\
\hline 699-S30-E10A & Trichloroethene & CLP_VOA_GCMS & 5/14/1990 1:32 PM & 2 & $\mathrm{ug} / \mathrm{L}$ & & \\
\hline 699-S30-E10A & Trichloroethene & CLP_VOA_GCMS & 8/27/1990 12:23 PM & 2 & ug/L & & \\
\hline 699-S30-E10A & Trichloroethene & 502.2_VOA_GC & 11/28/1990 8:44 AM & 1.2 & ug/L & & \\
\hline 699-S30-E10A & Trichloroethene & CLP_VOA_GCMS & 11/28/1990 9:02 AM & 2 & ug/L & U & \\
\hline 699-S30-E10A & Trichloroethene & CLP_VOA_GCMS & 11/28/1990 9:02 AM & 2 & $\mathrm{ug} / \mathrm{L}$ & $\mathrm{U}$ & \\
\hline 699-S30-E10A & Trichloroethene & CLP_VOA_GCMS & 3/15/1991 8:35 AM & 5 & ug/L & $\mathrm{U}$ & \\
\hline 699-S30-E10A & Trichloroethene & CLP_VOA_GCMS & 6/5/1991 1:03 PM & & ug/L & $\mathrm{J}$ & \\
\hline 699-S30-E10A & Trichloroethene & CLP_VOA_GCMS & 6/5/1991 1:03 PM & 2 & ug/L & $\mathrm{J}$ & \\
\hline 699-S30-E10A & Trichloroethene & 502.2_VOA_GC & 7/24/1991 9:37 AM & 3.6 & $\mathrm{ug} / \mathrm{L}$ & & \\
\hline 699-S30-E10A & Trichloroethene & CLP_VOA_GCMS & 8/14/1991 7:58 AM & 3 & ug/L & $\mathrm{J}$ & \\
\hline 699-S30-E10A & Trichloroethene & CLP_VOA_GCMS & 9/17/1991 11:53 AM & 3 & ug/L & $\mathrm{J}$ & \\
\hline 699-S30-E10A & Trichloroethene & CLP_VOA_GCMS & 11/13/1991 9:23 AM & 3 & ug/L & $\mathrm{J}$ & \\
\hline 699-S30-E10A & Trichloroethene & 502.2_VOA_GC & 12/10/1991 10:35 AM & 3.1 & ug/L & & \\
\hline 699-S30-E10A & Trichloroethene & 502.2_VOA_GC & 3/2/1992 11:00 AM & 5.8 & $\mathrm{ug} / \mathrm{L}$ & & \\
\hline 699-S30-E10A & Trichloroethene & 502.2_VOA_GC & 4/7/1992 9:00 AM & 4.2 & $\mathrm{ug} / \mathrm{L}$ & & \\
\hline 699-S30-E10A & Trichloroethene & 8260_VOA_GCMS & 5/13/1992 8:57 AM & 4 & ug/L & & \\
\hline 699-S30-E10A & Trichloroethene & 502.2_VOA_GC & 8/5/1992 10:40 AM & 4.7 & ug/L & & \\
\hline 699-S30-E10A & Trichloroethene & 8260_VOA_GCMS & 9/14/1992 9:00 AM & 4 & ug/L & & \\
\hline 699-S30-E10A & Trichloroethene & 8240_VOA_GCMS & 12/7/1992 11:05 AM & 4 & $\mathrm{ug} / \mathrm{L}$ & & \\
\hline 699-S30-E10A & Trichloroethene & 8240_VOA_GCMS & 3/15/1993 11:14 AM & 5 & $\mathrm{ug} / \mathrm{L}$ & $\mathrm{J}$ & \\
\hline 699-S30-E10A & Trichloroethene & 8260_VOA_GCMS & 6/7/1993 10:07 AM & 7 & ug/L & & \\
\hline 699-S30-E10A & Trichloroethene & 502.2_VOA_GC & 7/30/1993 8:45 AM & 7.5 & ug/L & & \\
\hline 699-S30-E10A & Trichloroethene & 8240_VOA_GCMS & 9/23/1993 9:00 AM & 6 & $\mathrm{ug} / \mathrm{L}$ & & \\
\hline 699-S30-E10A & Trichloroethene & 8260_VOA_GCMS & 12/2/1993 9:00 AM & 7 & $\mathrm{ug} / \mathrm{L}$ & & \\
\hline 699-S30-E10A & Trichloroethene & 8260_VOA_GCMS & 3/21/1994 12:25 PM & 11 & ug/L & $U$ & \\
\hline 699-S30-E10A & Trichloroethene & 8260_VOA_GCMS & 6/6/1994 12:00 PM & 13 & ug/L & UJ & \\
\hline 699-S30-E10A & Trichloroethene & 502.2_VOA_GC & 7/11/1994 8:45 AM & 14 & $\mathrm{ug} / \mathrm{L}$ & & \\
\hline 699-S30-E10A & Trichloroethene & 8260_VOA_GCMS & 10/11/1994 1:15 PM & 11 & ug/L & & \\
\hline 699-S30-E10A & Trichloroethene & 502.2_VOA_GC & 1/16/1995 8:50 AM & 11 & ug/L & & \\
\hline 699-S30-E10A & Trichloroethene & 8260_VOA_GCMS & 4/10/1995 11:43 AM & 8.1 & ug/L & & \\
\hline 699-S30-E10A & Trichloroethene & 8010_VOA_GC & 1/12/1996 1:00 PM & 5.7 & ug/L & & \\
\hline 699-S30-E10A & Trichloroethene & 8240_VOA_GCMS & 5/22/1996 9:06 AM & 7.74 & $\mathrm{ug} / \mathrm{L}$ & & \\
\hline 699-S30-E10A & Trichloroethene & 8240_VOA_GCMS & 5/22/1996 9:06 AM & 6 & $\mathrm{ug} / \mathrm{L}$ & & \\
\hline 699-S30-E10A & Trichloroethene & 8240_VOA_GCMS & 5/22/1996 9:06 AM & 6 & ug/L & & \\
\hline 699-S30-E10A & Trichloroethene & 8260_VOA_GCMS & 5/22/1997 11:08 AM & 5 & $\mathrm{ug} / \mathrm{L}$ & & \\
\hline 699-S30-E10A & Trichloroethene & 8260_VOA_GCMS & 6/22/1998 11:18 AM & 4 & ug/L & $\mathrm{J}$ & \\
\hline 699-S30-E10A & Trichloroethene & 8260_VOA_GCMS & 6/22/1998 11:18 AM & 4 & $\mathrm{ug} / \mathrm{L}$ & $\mathrm{J}$ & \\
\hline 699-S30-E10A & Trichloroethene & 8260_VOA_GCMS & 6/14/1999 12:27 PM & 2 & ug/L & $\mathrm{J}$ & \\
\hline 699-S30-E10A & Trichloroethene & 8260_VOA_GCMS & 10/11/2000 12:09 PM & 1.6 & $\mathrm{ug} / \mathrm{L}$ & & \\
\hline 699-S30-E10A & Trichloroethene & 8260_VOA_GCMS & 5/1/2001 11:45 AM & 1.8 & ug/L & $\mathrm{J}$ & \\
\hline 699-S30-E10A & Trichloroethene & 8260_VOA_GCMS & $7 / 31 / 2002$ 10:49 AM & 1.6 & ug/L & $\mathrm{J}$ & $Q$ \\
\hline 699-S30-E10A & Trichloroethene & 8260_VOA_GCMS & 7/22/2003 9:55 AM & 1.3 & $\mathrm{ug} / \mathrm{L}$ & & \\
\hline 699-S30-E10A & Trichloroethene & 8260_VOA_GCMS & $7 / 15 / 2004$ 11:12 AM & 0.86 & ug/L & $\mathrm{J}$ & \\
\hline 699-S30-E10A & Trichloroethene & 8260_VOA_GCMS & $7 / 14 / 2005$ 11:32 AM & 0.86 & $\mathrm{ug} / \mathrm{L}$ & $\mathrm{JB}$ & \\
\hline 699-S30-E10A & Trichloroethene & 8260_VOA_GCMS & 11/6/2006 12:11 PM & 0.59 & $\mathrm{ug} / \mathrm{L}$ & $\mathrm{J}$ & \\
\hline 699-S30-E10B & Trichloroethene & CLP_VOA_GCMS & 2/6/1990 8:22 AM & 2 & ug/L & & \\
\hline 699-S30-E10B & Trichloroethene & CLP_VOA_GCMS & 2/6/1990 8:22 AM & 0.9 & ug/L & $\mathrm{J}$ & \\
\hline 699-S30-E10B & Trichloroethene & CLP_VOA_GCMS & 5/15/1990 8:42 AM & 3 & $\mathrm{ug} / \mathrm{L}$ & & \\
\hline
\end{tabular}




\begin{tabular}{|c|c|c|c|c|c|c|c|}
\hline Well Name & Constituent & Method Name & Sample Date/Time & Value & Units & \begin{tabular}{|c|} 
Lab \\
Qualifier \\
\end{tabular} & $\begin{array}{l}\text { Review } \\
\text { Qualifier } \\
\end{array}$ \\
\hline 699-S30-E10B & Trichloroethene & CLP_VOA_GCMS & $8 / 27 / 19901: 36 \mathrm{PM}$ & 2 & ug/L & & \\
\hline 699-S30-E10B & Trichloroethene & 502.2_VOA_GC & $11 / 28 / 1990$ 10:57 AM & 2.4 & ug/L & & \\
\hline 699-S30-E10B & Trichloroethene & CLP_VOA_GCMS & 11/28/1990 11:16 AM & 5 & $\mathrm{ug} / \mathrm{L}$ & $\mathrm{U}$ & \\
\hline 699-S30-E10B & Trichloroethene & CLP_VOA_GCMS & 11/28/1990 11:16 AM & 3 & $\mathrm{ug} / \mathrm{L}$ & & \\
\hline 699-S30-E10B & Trichloroethene & CLP_VOA_GCMS & 3/15/1991 9:34 AM & 5 & $\mathrm{ug} / \mathrm{L}$ & $U$ & \\
\hline 699-S30-E10B & Trichloroethene & CLP_VOA_GCMS & 3/15/1991 9:34 AM & 5 & ug/L & U & \\
\hline 699-S30-E10B & Trichloroethene & CLP_VOA_GCMS & 6/5/1991 1:42 PM & & ug/L & $\mathrm{J}$ & \\
\hline 699-S30-E10B & Trichloroethene & CLP_VOA_GCMS & 6/5/1991 1:42 PM & 3 & $\mathrm{ug} / \mathrm{L}$ & $\mathrm{J}$ & \\
\hline 699-S30-E10B & Trichloroethene & 502.2_VOA_GC & 7/24/1991 8:56 AM & 3.4 & ug/L & & \\
\hline 699-S30-E10B & Trichloroethene & CLP_VOA_GCMS & 8/14/1991 6:55 AM & 3 & $\mathrm{ug} / \mathrm{L}$ & $\mathrm{J}$ & \\
\hline 699-S30-E10B & Trichloroethene & CLP_VOA_GCMS & 8/14/1991 6:55 AM & 3 & ug/L & $\mathrm{J}$ & \\
\hline 699-S30-E10B & Trichloroethene & CLP_VOA_GCMS & 8/14/1991 6:55 AM & 3 & ug/L & $\mathrm{J}$ & \\
\hline 699-S30-E10B & Trichloroethene & CLP_VOA_GCMS & 9/17/1991 12:37 PM & 4 & $\mathrm{ug} / \mathrm{L}$ & $\mathrm{J}$ & \\
\hline 699-S30-E10B & Trichloroethene & CLP_VOA_GCMS & 11/13/1991 10:21 AM & 4 & $\mathrm{ug} / \mathrm{L}$ & $\mathrm{J}$ & \\
\hline 699-S30-E10B & Trichloroethene & 502.2_VOA_GC & 12/10/1991 10:10 AM & 10.2 & ug/L & & \\
\hline 699-S30-E10B & Trichloroethene & 502.2_VOA_GC & 3/2/1992 10:30 AM & 12 & ug/L & & \\
\hline 699-S30-E10B & Trichloroethene & 502.2_VOA_GC & 4/7/1992 8:15 AM & 9.6 & ug/L & & \\
\hline 699-S30-E10B & Trichloroethene & 8260_VOA_GCMS & 5/13/1992 9:50 AM & 7 & $\mathrm{ug} / \mathrm{L}$ & & \\
\hline 699-S30-E10B & Trichloroethene & 502.2_VOA_GC & $8 / 5 / 1992$ 10:20 AM & 5.2 & ug/L & & \\
\hline 699-S30-E10B & Trichloroethene & 8260_VOA_GCMS & 9/14/1992 10:00 AM & 8 & $\mathrm{ug} / \mathrm{L}$ & & \\
\hline 699-S30-E10B & Trichloroethene & 8240_VOA_GCMS & 12/7/1992 11:45 AM & 18 & ug/L & & \\
\hline 699-S30-E10B & Trichloroethene & 8240_VOA_GCMS & 3/15/1993 10:38 AM & 13 & ug/L & & \\
\hline 699-S30-E10B & Trichloroethene & 8260_VOA_GCMS & 6/7/1993 10:47 AM & 16 & $\mathrm{ug} / \mathrm{L}$ & & \\
\hline 699-S30-E10B & Trichloroethene & 502.2_VOA_GC & 7/30/1993 8:30 AM & 0.5 & ug/L & U & \\
\hline 699-S30-E10B & Trichloroethene & 8240_VOA_GCMS & 9/23/1993 9:42 AM & 16 & ug/L & & \\
\hline 699-S30-E10B & Trichloroethene & 8260_VOA_GCMS & 12/2/1993 9:40 AM & 14 & ug/L & & \\
\hline 699-S30-E10B & Trichloroethene & 8260_VOA_GCMS & 3/21/1994 11:15 AM & 17 & $\mathrm{ug} / \mathrm{L}$ & U & \\
\hline 699-S30-E10B & Trichloroethene & 8260_VOA_GCMS & 6/6/1994 1:25 AM & 15 & $\mathrm{ug} / \mathrm{L}$ & $\mathrm{U}$ & \\
\hline 699-S30-E10B & Trichloroethene & 502.2_VOA_GC & 7/8/1994 9:45 AM & 20 & $\mathrm{ug} / \mathrm{L}$ & & \\
\hline 699-S30-E10B & Trichloroethene & 8260_VOA_GCMS & 10/11/1994 12:40 PM & 22 & ug/L & & \\
\hline 699-S30-E10B & Trichloroethene & 502.2_VOA_GC & 1/16/1995 8:15 AM & 20 & ug/L & & \\
\hline 699-S30-E10B & Trichloroethene & 8260_VOA_GCMS & 4/10/1995 12:30 PM & 2.4 & $\mathrm{ug} / \mathrm{L}$ & & \\
\hline 699-S30-E10B & Trichloroethene & 8240_VOA_GCMS & 5/22/1996 10:25 AM & 10.6 & $\mathrm{ug} / \mathrm{L}$ & & \\
\hline 699-S30-E10B & Trichloroethene & 8240_VOA_GCMS & 5/22/1996 10:25 AM & 10 & ug/L & & \\
\hline 699-S30-E10B & Trichloroethene & 8240_VOA_GCMS & $5 / 22 / 1996$ 10:25 AM & 9 & ug/L & & \\
\hline 699-S30-E10B & Trichloroethene & 8010_VOA_GC & 1/20/1997 11:26 AM & 7.4 & $\mathrm{ug} / \mathrm{L}$ & & \\
\hline 699-S30-E10B & Trichloroethene & 8260_VOA_GCMS & 1/20/1998 9:40 AM & 5 & $\mathrm{ug} / \mathrm{L}$ & & \\
\hline 699-S30-E10B & Trichloroethene & 8260_VOA_GCMS & 1/20/1998 9:40 AM & 6 & ug/L & & \\
\hline 699-S30-E10B & Trichloroethene & 8260_VOA_GCMS & 1/20/1999 12:21 PM & 4 & ug/L & $\mathrm{J}$ & \\
\hline 699-S30-E10B & Trichloroethene & 8260_VOA_GCMS & 5/2/2001 10:05 AM & 2.3 & ug/L & $\mathrm{J}$ & \\
\hline 699-S30-E10B & Trichloroethene & 8260_VOA_GCMS & 7/31/2002 10:13 AM & 1.9 & $\mathrm{ug} / \mathrm{L}$ & $\mathrm{J}$ & $\mathrm{Q}$ \\
\hline 699-S30-E10B & Trichloroethene & 8260_VOA_GCMS & 7/21/2003 12:15 PM & 1.8 & $\mathrm{ug} / \mathrm{L}$ & & \\
\hline 699-S30-E10B & Trichloroethene & 8260_VOA_GCMS & $7 / 15 / 2004$ 10:35 AM & 1.6 & ug/L & & \\
\hline 699-S30-E10B & Trichloroethene & 8260_VOA_GCMS & $7 / 25 / 2005$ 11:00 AM & 1.5 & $\mathrm{ug} / \mathrm{L}$ & & \\
\hline 699-S30-E10B & Trichloroethene & 8260_VOA_GCMS & 11/6/2006 12:53 PM & 1.1 & ug/L & & \\
\hline 699-S30-E11A & Trichloroethene & 8240_VOA_GCMS & 5/20/1996 9:20 AM & 8 & $\mathrm{ug} / \mathrm{L}$ & & \\
\hline 699-S30-E11A & Trichloroethene & 8260_VOA_GCMS & 5/22/1997 8:59 AM & 8 & $\mathrm{ug} / \mathrm{L}$ & & \\
\hline 699-S30-E11A & Trichloroethene & 8260_VOA_GCMS & 6/19/1998 12:40 PM & 8 & $\mathrm{ug} / \mathrm{L}$ & & \\
\hline 699-S30-E11A & Trichloroethene & 8260_VOA_GCMS & $6 / 14 / 1999$ 11:20 AM & 4 & ug/L & $\mathrm{J}$ & \\
\hline 699-S30-E11A & Trichloroethene & 8260_VOA_GCMS & 10/11/2000 1:08 PM & 4.2 & ug/L & & \\
\hline 699-S30-E11A & Trichloroethene & 8260_VOA_GCMS & 5/1/2001 10:43 AM & 3.6 & $\mathrm{ug} / \mathrm{L}$ & $\mathrm{J}$ & \\
\hline 699-S30-E11A & Trichloroethene & 8260_VOA_GCMS & 7/25/2002 12:03 PM & 3.2 & ug/L & $\mathrm{J}$ & \\
\hline 699-S30-E11A & Trichloroethene & 8260_VOA_GCMS & 9/10/2003 11:31 AM & 3.1 & $\mathrm{ug} / \mathrm{L}$ & & \\
\hline 699-S30-E11A & Trichloroethene & 8260_VOA_GCMS & $7 / 14 / 200411: 55 \mathrm{AM}$ & 2 & $\mathrm{ug} / \mathrm{L}$ & & \\
\hline 699-S30-E11A & Trichloroethene & 8260_VOA_GCMS & 9/29/2005 11:50 AM & 1.7 & ug/L & & \\
\hline 699-S30-E11A & Trichloroethene & 8260_VOA_GCMS & 11/6/2006 2:22 PM & 1.6 & $\mathrm{ug} / \mathrm{L}$ & & \\
\hline 699-S31-E10A & Trichloroethene & CLP_VOA_GCMS & 2/14/1990 4:01 PM & 92 & ug/L & $D$ & \\
\hline
\end{tabular}




\begin{tabular}{|c|c|c|c|c|c|c|c|}
\hline Well Name & Constituent & Method Name & Sample Date/Time & Value & Units & \begin{tabular}{|c|} 
Lab \\
Qualifier \\
\end{tabular} & \begin{tabular}{|l|} 
Review \\
Qualifier
\end{tabular} \\
\hline 699-S31-E10A & Trichloroethene & CLP_VOA_GCMS & 5/15/1990 10:06 AM & 110 & ug/L & $\mathrm{D}$ & \\
\hline 699-S31-E10A & Trichloroethene & CLP_VOA_GCMS & 5/15/1990 10:06 AM & 97 & $\mathrm{ug} / \mathrm{L}$ & $D$ & \\
\hline 699-S31-E10A & Trichloroethene & CLP_VOA_GCMS & 8/28/1990 9:00 AM & 84 & ug/L & $\mathrm{D}$ & \\
\hline 699-S31-E10A & Trichloroethene & CLP_VOA_GCMS & 8/28/1990 9:00 AM & 91 & ug/L & & \\
\hline 699-S31-E10A & Trichloroethene & CLP_VOA_GCMS & 11/26/1990 11:58 AM & 74 & ug/L & & \\
\hline 699-S31-E10A & Trichloroethene & 502.2_VOA_GC & 11/26/1990 12:49 PM & 84 & $\mathrm{ug} / \mathrm{L}$ & & \\
\hline 699-S31-E10A & Trichloroethene & CLP_VOA_GCMS & 3/15/1991 11:03 AM & 79 & $\mathrm{ug} / \mathrm{L}$ & & \\
\hline 699-S31-E10A & Trichloroethene & CLP_VOA_GCMS & 6/4/1991 9:02 AM & 78 & ug/L & & \\
\hline 699-S31-E10A & Trichloroethene & 502.2_VOA_GC & 7/23/1991 11:10 AM & 81 & ug/L & & \\
\hline 699-S31-E10A & Trichloroethene & CLP_VOA_GCMS & 8/12/1991 8:20 AM & 69 & ug/L & & \\
\hline 699-S31-E10A & Trichloroethene & CLP_VOA_GCMS & 9/16/1991 11:01 AM & 67 & $\mathrm{ug} / \mathrm{L}$ & & \\
\hline 699-S31-E10A & Trichloroethene & CLP_VOA_GCMS & 11/12/1991 8:38 AM & 69 & ug/L & & \\
\hline 699-S31-E10A & Trichloroethene & 8240_VOA_GCMS & 3/10/1992 9:18 AM & 41 & ug/L & $E$ & \\
\hline 699-S31-E10A & Trichloroethene & CLP_VOA_GCMS & 3/10/1992 9:54 AM & 9 & ug/L & $\mathrm{J}$ & \\
\hline 699-S31-E10A & Trichloroethene & 8240_VOA_GCMS & 3/10/1992 10:11 AM & 57 & $\mathrm{ug} / \mathrm{L}$ & & \\
\hline 699-S31-E10A & Trichloroethene & 502.2_VOA_GC & 3/11/1992 1:45 PM & 53 & ug/L & & \\
\hline 699-S31-E10A & Trichloroethene & 8240_VOA_GCMS & 5/11/1992 12:00 AM & 58 & $\overline{u g} / \mathrm{L}$ & & \\
\hline 699-S31-E10A & Trichloroethene & 502.2_VOA_GC & 8/5/1992 7:45 AM & 55 & ug/L & & \\
\hline 699-S31-E10A & Trichloroethene & 8260_VOA_GCMS & 9/14/1992 1:00 PM & 42 & ug/L & $E$ & \\
\hline 699-S31-E10A & Trichloroethene & 8260_VOA_GCMS & 9/14/1992 1:00 PM & 39 & ug/L & $E$ & \\
\hline 699-S31-E10A & Trichloroethene & 8240_VOA_GCMS & 12/8/1992 10:00 AM & 54 & $\mathrm{ug} / \mathrm{L}$ & & \\
\hline 699-S31-E10A & Trichloroethene & 8240_VOA_GCMS & 3/16/1993 8:56 AM & 61 & ug/L & & \\
\hline 699-S31-E10A & Trichloroethene & 8240_VOA_GCMS & 3/16/1993 9:10 AM & 57 & ug/L & & \\
\hline 699-S31-E10A & Trichloroethene & 8260_VOA_GCMS & 6/8/1993 9:32 AM & 46 & ug/L & & \\
\hline 699-S31-E10A & Trichloroethene & 8260_VOA_GCMS & 6/8/1993 9:32 AM & 36 & $\mathrm{ug} / \mathrm{L}$ & & \\
\hline 699-S31-E10A & Trichloroethene & 502.2_VOA_GC & 8/3/1993 9:10 AM & 47 & $\mathrm{ug} / \mathrm{L}$ & & \\
\hline 699-S31-E10A & Trichloroethene & 8240_VOA_GCMS & 9/22/1993 10:00 AM & 44 & $\mathrm{ug} / \mathrm{L}$ & U & \\
\hline 699-S31-E10A & Trichloroethene & 8240_VOA_GCMS & 9/22/1993 10:00 AM & 45 & ug/L & $\mathrm{U}$ & \\
\hline 699-S31-E10A & Trichloroethene & 8260_VOA_GCMS & 11/30/1993 10:40 AM & 53 & ug/L & & \\
\hline 699-S31-E10A & Trichloroethene & 8260_VOA_GCMS & 11/30/1993 10:40 AM & 1 & ug/L & & \\
\hline 699-S31-E10A & Trichloroethene & 8260_VOA_GCMS & 3/22/1994 9:50 AM & 46 & ug/L & & \\
\hline 699-S31-E10A & Trichloroethene & 8260_VOA_GCMS & 3/22/1994 9:50 AM & 42 & ug/L & U & \\
\hline 699-S31-E10A & Trichloroethene & 8260_VOA_GCMS & 6/7/1994 9:46 AM & 41 & $\mathrm{ug} / \mathrm{L}$ & & \\
\hline 699-S31-E10A & Trichloroethene & 502.2_VOA_GC & 7/26/1994 8:45 AM & 13 & ug/L & & \\
\hline 699-S31-E10A & Trichloroethene & 8260_VOA_GCMS & 10/12/1994 10:15 AM & 30 & $\mathrm{ug} / \mathrm{L}$ & & \\
\hline 699-S31-E10A & Trichloroethene & 8260_VOA_GCMS & 4/12/1995 9:30 AM & 1 & ug/L & & \\
\hline 699-S31-E10A & Trichloroethene & 8260_VOA_GCMS & 4/12/1995 9:30 AM & 23 & $\mathrm{ug} / \mathrm{L}$ & & \\
\hline 699-S31-E10A & Trichloroethene & 8010_VOA_GC & 11/17/1995 12:00 PM & 5.9 & $\mathrm{ug} / \mathrm{L}$ & & \\
\hline 699-S31-E10A & Trichloroethene & 8240_VOA_GCMS & 5/22/1996 11:17 AM & 14 & $\mathrm{ug} / \mathrm{L}$ & & \\
\hline 699-S31-E10A & Trichloroethene & 8260_VOA_GCMS & 5/22/1997 12:07 PM & 11 & ug/L & & \\
\hline 699-S31-E10A & Trichloroethene & 8260_VOA_GCMS & 6/22/1998 10:37 AM & 0.4 & $\mathrm{ug} / \mathrm{L}$ & U & \\
\hline 699-S31-E10A & Trichloroethene & 8260_VOA_GCMS & 6/22/1998 10:37 AM & 20 & ug/L & & \\
\hline 699-S31-E10A & Trichloroethene & 8260_VOA_GCMS & 6/14/1999 11:48 AM & 6 & ug/L & & \\
\hline 699-S31-E10A & Trichloroethene & 8260_VOA_GCMS & 10/11/2000 11:21 AM & 5.1 & $\mathrm{ug} / \mathrm{L}$ & & \\
\hline 699-S31-E10A & Trichloroethene & 8260_VOA_GCMS & 5/1/2001 11:13 AM & 4.4 & ug/L & $\mathrm{J}$ & \\
\hline 699-S31-E10A & Trichloroethene & 8260_VOA_GCMS & $7 / 26 / 2002$ 12:24 PM & 3.1 & ug/L & $\mathrm{J}$ & \\
\hline 699-S31-E10A & Trichloroethene & 8260_VOA_GCMS & $7 / 22 / 2003$ 10:16 AM & 2.9 & ug/L & & \\
\hline 699-S31-E10A & Trichloroethene & 8260_VOA_GCMS & 7/14/2004 12:32 PM & 2.3 & $\mathrm{ug} / \mathrm{L}$ & & \\
\hline 699-S31-E10A & Trichloroethene & 8260_VOA_GCMS & 9/29/2005 9:21 AM & 1.5 & $\mathrm{ug} / \mathrm{L}$ & & \\
\hline 699-S31-E10A & Trichloroethene & 8260_VOA_GCMS & 3/29/2006 12:28 PM & 1.4 & ug/L & & \\
\hline 699-S31-E10C & Trichloroethene & CLP_VOA_GCMS & 2/5/1990 10:58 AM & 40 & ug/L & $\mathrm{D}$ & \\
\hline 699-S31-E10C & Trichloroethene & CLP_VOA_GCMS & 5/15/1990 2:02 PM & 73 & ug/L & D & \\
\hline 699-S31-E10C & Trichloroethene & CLP_VOA_GCMS & 8/28/1990 10:18 AM & 52 & ug/L & $D$ & \\
\hline 699-S31-E10C & Trichloroethene & CLP_VOA_GCMS & 11/27/1990 12:31 PM & 66 & ug/L & & \\
\hline 699-S31-E10C & Trichloroethene & 502.2_VOA_GC & 11/27/1990 1:13 PM & 66 & ug/L & & \\
\hline 699-S31-E10C & Trichloroethene & CLP_VOA_GCMS & 3/15/1991 12:36 PM & 82 & ug/L & & \\
\hline 699-S31-E10C & Trichloroethene & CLP_VOA_GCMS & 6/4/1991 12:39 PM & 75 & ug/L & & \\
\hline
\end{tabular}




\begin{tabular}{|c|c|c|c|c|c|c|c|}
\hline Well Name & Constituent & Method Name & Sample Date/Time & Value & Units & $\begin{array}{c}\text { Lab } \\
\text { Qualifier }\end{array}$ & $\begin{array}{l}\text { Review } \\
\text { Qualifier }\end{array}$ \\
\hline 699-S31-E10C & Trichloroethene & 502.2_VOA_GC & 7/23/1991 10:40 AM & 45 & ug/L & & \\
\hline 699-S31-E10C & Trichloroethene & CLP_VOA_GCMS & 8/12/1991 10:05 AM & 75 & ug/L & & \\
\hline 699-S31-E10C & Trichloroethene & CLP_VOA_GCMS & 9/16/1991 9:35 AM & 76 & ug/L & & \\
\hline 699-S31-E10C & Trichloroethene & CLP_VOA_GCMS & 11/12/1991 10:16 AM & 67 & ug/L & & \\
\hline 699-S31-E10C & Trichloroethene & 8240_VOA_GCMS & 3/10/1992 11:36 AM & 72 & ug/L & $D$ & \\
\hline 699-S31-E10C & Trichloroethene & 8240_VOA_GCMS & 3/10/1992 11:49 AM & 42 & $u g / L$ & $E$ & \\
\hline 699-S31-E10C & Trichloroethene & 8240_VOA_GCMS & 3/10/1992 11:58 AM & 54 & ug/L & $U$ & \\
\hline 699-S31-E10C & Trichloroethene & 502.2_VOA_GC & 3/11/1992 8:50 AM & 46 & ug/L & & \\
\hline 699-S31-E10C & Trichloroethene & 8240_VOA_GCMS & 5/12/1992 12:00 AM & 50 & $u g / L$ & & \\
\hline 699-S31-E10C & Trichloroethene & 8260_VOA_GCMS & 5/12/1992 10:27 AM & 43 & ug/L & $E$ & \\
\hline 699-S31-E10C & Trichloroethene & 502.2_VOA_GC & 8/5/1992 8:10 AM & 43 & ug/L & & \\
\hline 699-S31-E10C & Trichloroethene & 8260_VOA_GCMS & 9/14/1992 10:55 AM & 43 & ug/L & $E$ & \\
\hline 699-S31-E10C & Trichloroethene & 8260_VOA_GCMS & 9/14/1992 10:55 AM & 47 & ug/L & $E$ & \\
\hline 699-S31-E10C & Trichloroethene & 8240_VOA_GCMS & 12/7/1992 9:58 AM & 70 & $u g / L$ & & \\
\hline 699-S31-E10C & Trichloroethene & 8240_VOA_GCMS & 3/15/1993 9:53 AM & 56 & ug/L & & \\
\hline 699-S31-E10C & Trichloroethene & 8260_VOA_GCMS & 6/9/1993 6:57 AM & 57 & ug/L & & \\
\hline 699-S31-E10C & Trichloroethene & 8260_VOA_GCMS & 6/9/1993 10:05 AM & 50 & $u g / L$ & & \\
\hline 699-S31-E10C & Trichloroethene & 502.2_VOA_GC & 8/3/1993 8:40 AM & 40 & ug/L & & \\
\hline 699-S31-E10C & Trichloroethene & 8240_VOA_GCMS & 9/21/1993 8:30 AM & 48 & $\mathrm{ug} / \mathrm{L}$ & $U$ & \\
\hline 699-S31-E10C & Trichloroethene & 8240_VOA_GCMS & 9/21/1993 9:54 AM & 51 & ug/L & $U$ & \\
\hline 699-S31-E10C & Trichloroethene & 8260_VOA_GCMS & 11/30/1993 9:40 AM & 1 & ug/L & & \\
\hline 699-S31-E10C & Trichloroethene & 8260_VOA_GCMS & 11/30/1993 9:40 AM & 1 & ug/L & & \\
\hline 699-S31-E10C & Trichloroethene & 8260_VOA_GCMS & 3/21/1994 10:22 AM & 35 & $\mathrm{ug} / \mathrm{L}$ & $U$ & \\
\hline 699-S31-E10C & Trichloroethene & 8260_VOA_GCMS & 3/21/1994 10:22 AM & 31 & ug/L & $U$ & \\
\hline 699-S31-E10C & Trichloroethene & 8260_VOA_GCMS & 6/6/1994 9:22 AM & 30 & $\mathrm{ug} / \mathrm{L}$ & & \\
\hline 699-S31-E10C & Trichloroethene & 8260_VOA_GCMS & 6/6/1994 9:22 AM & 33 & ug/L & & \\
\hline 699-S31-E10C & Trichloroethene & 502.2_VOA_GC & 7/8/1994 8:30 AM & 25 & ug/L & & \\
\hline 699-S31-E10C & Trichloroethene & 8260_VOA_GCMS & 10/11/1994 11:50 AM & 29 & ug/L & & \\
\hline 699-S31-E10C & Trichloroethene & 8260_VOA_GCMS & 10/11/1994 2:00 PM & 33 & ug/L & & \\
\hline 699-S31-E10C & Trichloroethene & 502.2_VOA_GC & 1/23/1995 8:16 AM & 30 & $u g / L$ & & \\
\hline 699-S31-E10C & Trichloroethene & 8260_VOA_GCMS & 4/11/1995 11:30 AM & 28 & ug/L & & \\
\hline 699-S31-E10C & Trichloroethene & 8240_VOA_GCMS & 5/22/1996 12:25 PM & 14 & ug/L & & \\
\hline 699-S31-E10C & Trichloroethene & 8260_VOA_GCMS & 5/20/1997 2:35 PM & 12 & ug/L & $B$ & \\
\hline 699-S31-E10C & Trichloroethene & 8260_VOA_GCMS & 6/19/1998 10:06 AM & 7 & $u g / L$ & & \\
\hline 699-S31-E10C & Trichloroethene & 8260_VOA_GCMS & 6/14/1999 11:01 AM & 6 & ug/L & & $G$ \\
\hline 699-S31-E10C & Trichloroethene & 8260_VOA_GCMS & 10/11/2000 10:31 AM & 4.9 & ug/L & & \\
\hline 699-S31-E10C & Trichloroethene & 8260_VOA_GCMS & 5/1/2001 10:30 AM & 4.4 & $\mathrm{ug} / \mathrm{L}$ & $\mathrm{J}$ & \\
\hline 699-S31-E10C & Trichloroethene & 8260_VOA_GCMS & $7 / 26 / 2002$ 11:45 AM & 3.4 & ug/L & $\mathrm{J}$ & \\
\hline 699-S31-E10C & Trichloroethene & 8260_VOA_GCMS & $7 / 22 / 2003$ 9:21 AM & 2.7 & $u g / L$ & & \\
\hline 699-S31-E10C & Trichloroethene & 8260_VOA_GCMS & 7/14/2004 10:50 AM & 2.1 & ug/L & & \\
\hline 699-S31-E10C & Trichloroethene & 8260_VOA_GCMS & 7/19/2005 11:54 AM & 1.9 & $\mathrm{ug} / \mathrm{L}$ & & $G$ \\
\hline 699-S31-E10C & Trichloroethene & 8260_VOA_GCMS & 11/18/2005 11:35 AM & 2.3 & $\mathrm{ug} / \mathrm{L}$ & & \\
\hline 699-S31-E10C & Trichloroethene & 8260_VOA_GCMS & 11/30/2006 9:24 AM & 1.7 & ug/L & & \\
\hline 699-S31-E10D & Trichloroethene & CLP_VOA_GCMS & $1 / 30 / 199011: 55 \mathrm{AM}$ & 84 & ug/L & & \\
\hline 699-S31-E10D & Trichloroethene & CLP_VOA_GCMS & 5/16/1990 12:00 PM & 83 & ug/L & & \\
\hline 699-S31-E10D & Trichloroethene & CLP_VOA_GCMS & 5/16/1990 12:00 PM & 80 & ug/L & $D$ & \\
\hline 699-S31-E10D & Trichloroethene & CLP_VOA_GCMS & 8/28/1990 12:40 PM & 75 & ug/L & $D$ & \\
\hline 699-S31-E10D & Trichloroethene & 502.2_VOA_GC & 11/27/1990 2:12 PM & 79 & ug/L & & \\
\hline 699-S31-E10D & Trichloroethene & CLP_VOA_GCMS & 11/27/1990 2:18 PM & 59 & ug/L & & \\
\hline 699-S31-E10D & Trichloroethene & CLP_VOA_GCMS & 3/15/1991 2:07 PM & 60 & ug/L & & \\
\hline 699-S31-E10D & Trichloroethene & CLP_VOA_GCMS & 6/17/1991 10:20 AM & 62 & ug/L & & \\
\hline 699-S31-E10D & Trichloroethene & 502.2_VOA_GC & 7/23/1991 9:30 AM & 48 & ug/L & & \\
\hline 699-S31-E10D & Trichloroethene & CLP_VOA_GCMS & 8/12/1991 11:12 AM & 70 & ug/L & & \\
\hline 699-S31-E10D & Trichloroethene & CLP_VOA_GCMS & 9/16/1991 11:45 AM & 66 & ug/L & & \\
\hline 699-S31-E10D & Trichloroethene & CLP_VOA_GCMS & 11/12/1991 10:53 AM & 64 & ug/L & & \\
\hline 699-S31-E10D & Trichloroethene & 8240_VOA_GCMS & 3/10/1992 1:23 AM & 38 & ug/L & & \\
\hline 699-S31-E10D & Trichloroethene & 8240_VOA_GCMS & 3/10/1992 12:56 PM & 28 & $\mathrm{ug} / \mathrm{L}$ & $E$ & \\
\hline
\end{tabular}




\begin{tabular}{|c|c|c|c|c|c|c|c|}
\hline Well Name & Constituent & Method Name & Sample Date/Time & Value & Units & \begin{tabular}{|c|} 
Lab \\
Qualifier \\
\end{tabular} & $\begin{array}{c}\text { Review } \\
\text { Qualifier } \\
\end{array}$ \\
\hline 699-S31-E10D & Trichloroethene & 502.2_VOA_GC & 3/11/1992 9:40 AM & 42 & ug/L & & \\
\hline 699-S31-E10D & Trichloroethene & 8240_VOA_GCMS & 5/12/1992 12:00 AM & 39 & ug/L & & \\
\hline 699-S31-E10D & Trichloroethene & 8260_VOA_GCMS & 5/12/1992 9:28 AM & 32 & $\mathrm{ug} / \mathrm{L}$ & $E$ & \\
\hline 699-S31-E10D & Trichloroethene & 502.2_VOA_GC & 8/5/1992 8:25 AM & 55 & $\mathrm{ug} / \mathrm{L}$ & & \\
\hline 699-S31-E10D & Trichloroethene & 8260_VOA_GCMS & 9/14/1992 2:43 PM & 39 & $\mathrm{ug} / \mathrm{L}$ & $E$ & \\
\hline 699-S31-E10D & Trichloroethene & 8240_VOA_GCMS & 12/7/1992 9:20 AM & 36 & ug/L & & \\
\hline 699-S31-E10D & Trichloroethene & 8240_VOA_GCMS & 3/15/1993 9:00 AM & 34 & ug/L & & \\
\hline 699-S31-E10D & Trichloroethene & 8260_VOA_GCMS & 6/7/1993 9:22 AM & 33 & $\mathrm{ug} / \mathrm{L}$ & & \\
\hline 699-S31-E10D & Trichloroethene & 502.2_VOA_GC & 8/3/1993 9:40 AM & 46 & $\mathrm{ug} / \mathrm{L}$ & & \\
\hline 699-S31-E10D & Trichloroethene & 8240_VOA_GCMS & 9/21/1993 9:00 AM & 48 & $\mathrm{ug} / \mathrm{L}$ & $U$ & \\
\hline 699-S31-E10D & Trichloroethene & 8260_VOA_GCMS & 11/30/1993 9:00 AM & 1 & ug/L & & \\
\hline 699-S31-E10D & Trichloroethene & 8260_VOA_GCMS & 3/21/1994 9:20 AM & 17 & ug/L & $U$ & \\
\hline 699-S31-E10D & Trichloroethene & 8260_VOA_GCMS & 6/6/1994 10:50 AM & 17 & ug/L & & \\
\hline 699-S31-E10D & Trichloroethene & 502.2_VOA_GC & 7/8/1994 8:00 AM & 22 & $\mathrm{ug} / \mathrm{L}$ & & \\
\hline 699-S31-E10D & Trichloroethene & 8260_VOA_GCMS & 10/11/1994 10:50 AM & 18 & ug/L & & \\
\hline 699-S31-E10D & Trichloroethene & 502.2_VOA_GC & 1/23/1995 8:40 AM & 18 & ug/L & & \\
\hline 699-S31-E10D & Trichloroethene & 8260_VOA_GCMS & 4/11/1995 10:45 AM & 13 & ug/L & & \\
\hline 699-S31-E10D & Trichloroethene & 8240_VOA_GCMS & 5/22/1996 1:04 PM & 6 & $\mathrm{ug} / \mathrm{L}$ & & \\
\hline 699-S31-E10D & Trichloroethene & 8260_VOA_GCMS & 5/20/1997 2:00 PM & 5 & ug/L & $\mathrm{B}$ & \\
\hline 699-S31-E10D & Trichloroethene & 8260_VOA_GCMS & 6/19/1998 9:07 AM & 6 & $\mathrm{ug} / \mathrm{L}$ & & \\
\hline 699-S31-E10D & Trichloroethene & 8260_VOA_GCMS & 6/15/1999 10:32 AM & 3 & ug/L & $\mathrm{J}$ & \\
\hline 699-S31-E10D & Trichloroethene & 8260_VOA_GCMS & 10/11/2000 9:24 AM & 2.7 & ug/L & & \\
\hline 699-S31-E10D & Trichloroethene & 8260_VOA_GCMS & 5/1/2001 1:21 PM & 2.4 & ug/L & $\mathrm{J}$ & \\
\hline 699-S31-E10D & Trichloroethene & 8260_VOA_GCMS & $7 / 26 / 2002$ 10:04 AM & 2.2 & $\mathrm{ug} / \mathrm{L}$ & $\mathrm{J}$ & \\
\hline 699-S31-E10D & Trichloroethene & 8260_VOA_GCMS & 7/22/2003 8:33 AM & 1.7 & ug/L & & \\
\hline 699-S31-E10D & Trichloroethene & 8260_VOA_GCMS & 7/14/2004 9:18 AM & 1.4 & ug/L & & \\
\hline 699-S31-E10D & Trichloroethene & 8260_VOA_GCMS & 9/29/2005 8:44 AM & 0.98 & $\mathrm{ug} / \mathrm{L}$ & $\mathrm{J}$ & \\
\hline 699-S31-E10D & Trichloroethene & 8260_VOA_GCMS & 3/29/2006 11:51 AM & 1 & $\mathrm{ug} / \mathrm{L}$ & & \\
\hline 699-S31-E11 & Trichloroethene & CLP_VOA_GCMS & 6/27/1991 1:48 PM & 5 & $\mathrm{ug} / \mathrm{L}$ & U & \\
\hline 699-S31-E11 & Trichloroethene & CLP_VOA_GCMS & 8/13/1991 10:03 AM & 5 & ug/L & $U$ & \\
\hline 699-S31-E11 & Trichloroethene & CLP_VOA_GCMS & 9/17/1991 8:17 AM & 5 & ug/L & U & \\
\hline 699-S31-E11 & Trichloroethene & CLP_VOA_GCMS & 11/14/1991 12:00 AM & 5 & $\mathrm{ug} / \mathrm{L}$ & U & \\
\hline 699-S31-E11 & Trichloroethene & 8260_VOA_GCMS & 5/11/1992 12:00 AM & 0.5 & $\mathrm{ug} / \mathrm{L}$ & $\mathrm{U}$ & \\
\hline 699-S31-E11 & Trichloroethene & 8260_VOA_GCMS & 9/16/1992 10:35 AM & 0.5 & ug/L & $U$ & \\
\hline 699-S31-E11 & Trichloroethene & 8240_VOA_GCMS & $3 / 17 / 1993$ 10:28 AM & 10 & ug/L & U & \\
\hline 699-S31-E11 & Trichloroethene & 8240_VOA_GCMS & 3/17/1993 10:34 AM & 10 & $\mathrm{ug} / \mathrm{L}$ & U & \\
\hline 699-S31-E11 & Trichloroethene & 8240_VOA_GCMS & 9/23/1993 10:50 AM & 5 & $\mathrm{ug} / \mathrm{L}$ & U & \\
\hline 699-S31-E11 & Trichloroethene & 8260_VOA_GCMS & 12/1/1993 10:50 AM & 1 & ug/L & U & \\
\hline 699-S31-E11 & Trichloroethene & 502.2_VOA_GC & 10/17/1994 8:15 AM & 0.2 & ug/L & $\mathrm{J}$ & \\
\hline 699-S31-E11 & Trichloroethene & 8260_VOA_GCMS & 4/10/1995 10:00 AM & 2.4 & ug/L & & \\
\hline 699-S31-E11 & Trichloroethene & 8240_VOA_GCMS & 5/24/1996 10:15 AM & 5 & $\mathrm{ug} / \mathrm{L}$ & U & \\
\hline 699-S31-E11 & Trichloroethene & 8260_VOA_GCMS & 5/22/1997 8:09 AM & 0.6 & $\mathrm{ug} / \mathrm{L}$ & $\mathrm{J}$ & \\
\hline \begin{tabular}{|l}
$699-S 31-E 11$ \\
\end{tabular} & Trichloroethene & 8260_VOA_GCMS & 6/19/1998 7:41 AM & 0.5 & $\mathrm{ug} / \mathrm{L}$ & $\mathrm{J}$ & \\
\hline 699-S31-E11 & Trichloroethene & 8260_VOA_GCMS & 6/19/1998 7:41 AM & 0.5 & $\mathrm{ug} / \mathrm{L}$ & $\mathrm{J}$ & \\
\hline 699-S31-E11 & Trichloroethene & 8260_VOA_GCMS & 6/15/1999 9:49 AM & 0.16 & ug/L & U & \\
\hline 699-S31-E11 & Trichloroethene & 8260_VOA_GCMS & 10/12/2000 12:02 PM & 0.24 & $\mathrm{ug} / \mathrm{L}$ & $\mathrm{J}$ & \\
\hline 699-S31-E11 & Trichloroethene & 8260_VOA_GCMS & 5/1/2001 9:50 AM & 0.4 & ug/L & $\mathrm{J}$ & \\
\hline 699-S31-E11 & Trichloroethene & 8260_VOA_GCMS & $7 / 25 / 2002$ 11:38 AM & 0.29 & $\mathrm{ug} / \mathrm{L}$ & U & \\
\hline 699-S31-E11 & Trichloroethene & 8260_VOA_GCMS & 7/31/2003 11:12 AM & 0.29 & ug/L & $\mathrm{J}$ & \\
\hline 699-S31-E11 & Trichloroethene & 8260_VOA_GCMS & 7/15/2004 12:04 PM & 0.27 & ug/L & $\mathrm{J}$ & \\
\hline 699-S31-E11 & Trichloroethene & 8260_VOA_GCMS & 9/29/2005 10:42 AM & 0.13 & $\mathrm{ug} / \mathrm{L}$ & U & \\
\hline 699-S31-E11 & Trichloroethene & 8260_VOA_GCMS & $3 / 29 / 2006$ 10:57 AM & 0.32 & ug/L & $\mathrm{J}$ & \\
\hline 699-S27-E12A & Vinyl chloride & 8240_VOA_GCMS & 5/20/1996 10:10 AM & 10 & $\mathrm{ug} / \mathrm{L}$ & U & \\
\hline 699-S27-E12A & Vinyl chloride & 8260_VOA_GCMS & 5/22/1997 10:24 AM & 1 & ug/L & U & \\
\hline 699-S27-E12A & Vinyl chloride & 8260_VOA_GCMS & 5/22/1997 10:24 AM & 1 & ug/L & U & \\
\hline 699-S27-E12A & Vinyl chloride & 8260_VOA_GCMS & 6/22/1998 1:28 PM & 0.68 & $\mathrm{ug} / \mathrm{L}$ & U & \\
\hline 699-S27-E12A & Vinyl chloride & 8260_VOA_GCMS & 6/22/1998 1:28 PM & 0.68 & $\mathrm{ug} / \mathrm{L}$ & U & \\
\hline
\end{tabular}




\begin{tabular}{|c|c|c|c|c|c|c|c|}
\hline Well Name & Constituent & Method Name & Sample Date/Time & Value & Units & $\begin{array}{c}\text { Lab } \\
\text { Qualifier } \\
\end{array}$ & $\begin{array}{c}\text { Review } \\
\text { Qualifier } \\
\end{array}$ \\
\hline 699-S27-E12A & Vinyl chloride & 8260_VOA_GCMS & 6/14/1999 10:07 AM & 0.1 & $u g / L$ & $U$ & \\
\hline 699-S27-E12A & Vinyl chloride & 8260_VOA_GCMS & 10/11/2000 10:05 AM & 0.17 & $u g / L$ & $U$ & \\
\hline 699-S27-E12A & Vinyl chloride & 8260_VOA_GCMS & 4/30/2001 1:16 PM & 0.17 & $\mathrm{ug} / \mathrm{L}$ & $\mathrm{U}$ & \\
\hline 699-S27-E12A & Vinyl chloride & 8260_VOA_GCMS & $7 / 25 / 2002$ 10:36 AM & 0.32 & ug/L & $\mathrm{U}$ & \\
\hline 699-S27-E12A & Vinyl chloride & 8260_VOA_GCMS & 7/21/2003 12:52 PM & 0.25 & ug/L & $U$ & \\
\hline 699-S27-E12A & Vinyl chloride & 8260_VOA_GCMS & 7/14/2004 11:01 AM & 0.08 & $u g / L$ & $U$ & \\
\hline 699-S27-E12A & Vinyl chloride & 8260_VOA_GCMS & 9/29/2005 9:55 AM & 0.07 & $\mathrm{ug} / \mathrm{L}$ & U & \\
\hline 699-S27-E12A & Vinyl chloride & 8260_VOA_GCMS & 11/6/2006 12:12 PM & 0.23 & $\mathrm{ug} / \mathrm{L}$ & $U$ & \\
\hline 699-S28-E12 & Vinyl chloride & CLP_VOA_GCMS & 6/17/1991 11:30 AM & 10 & $u g / L$ & $U$ & \\
\hline 699-S28-E12 & Vinyl chloride & CLP_VOA_GCMS & 8/16/1991 8:50 AM & 10 & $u g / L$ & $U$ & \\
\hline 699-S28-E12 & Vinyl chloride & CLP_VOA_GCMS & 9/19/1991 7:35 AM & 10 & ug/L & $U$ & \\
\hline 699-S28-E12 & Vinyl chloride & CLP_VOA_GCMS & 12/5/1991 12:00 AM & 10 & ug/L & $\mathrm{U}$ & \\
\hline 699-S28-E12 & Vinyl chloride & CLP_VOA_GCMS & 4/21/1992 12:00 AM & 10 & ug/L & U & \\
\hline 699-S28-E12 & Vinyl chloride & CLP_VOA_GCMS & 9/9/1992 12:00 AM & 10 & $u g / L$ & $\mathrm{U}$ & \\
\hline 699-S28-E12 & Vinyl chloride & CLP_VOA_GCMS & 3/12/1993 9:20 AM & 10 & $u g / L$ & $U$ & \\
\hline 699-S28-E12 & Vinyl chloride & 8010_VOA_GC & 1/17/1996 10:50 AM & 0.25 & ug/L & $\mathrm{U}$ & \\
\hline 699-S28-E12 & Vinyl chloride & 8260_VOA_GCMS & 5/22/1997 12:55 PM & 1 & ug/L & $\mathrm{U}$ & \\
\hline 699-S28-E12 & Vinyl chloride & 8260_VOA_GCMS & 6/19/1998 8:25 AM & 0.68 & $\mathrm{ug} / \mathrm{L}$ & $\mathrm{U}$ & \\
\hline 699-S28-E12 & Vinyl chloride & 8260_VOA_GCMS & 6/30/1998 7:52 AM & 0.68 & $\mathrm{ug} / \mathrm{L}$ & U & \\
\hline 699-S28-E12 & Vinyl chloride & 8260_VOA_GCMS & 6/14/1999 8:50 AM & 0.1 & ug/L & $U$ & \\
\hline 699-S28-E12 & Vinyl chloride & 8260_VOA_GCMS & 10/11/2000 9:23 AM & 0.17 & $u g / L$ & $U$ & \\
\hline 699-S28-E12 & Vinyl chloride & 8260_VOA_GCMS & 5/2/2001 11:53 AM & 0.17 & ug/L & $U$ & \\
\hline 699-S28-E12 & Vinyl chloride & 8260_VOA_GCMS & 7/25/2002 8:53 AM & 0.32 & ug/L & U & \\
\hline 699-S28-E12 & Vinyl chloride & 8260_VOA_GCMS & $7 / 25 / 20028: 53 \mathrm{AM}$ & 0.32 & ug/L & $\mathrm{U}$ & \\
\hline 699-S28-E12 & Vinyl chloride & 8260_VOA_GCMS & 9/10/2003 10:21 AM & 0.25 & ug/L & $U$ & \\
\hline 699-S28-E12 & Vinyl chloride & 8260_VOA_GCMS & $7 / 13 / 2004$ 11:46 AM & 0.08 & ug/L & $\mathrm{U}$ & \\
\hline 699-S28-E12 & Vinyl chloride & 8260_VOA_GCMS & 7/14/2005 10:59 AM & 0.07 & ug/L & U & \\
\hline 699-S28-E12 & Vinyl chloride & 8260_VOA_GCMS & 11/6/2006 12:50 PM & 0.23 & ug/L & $\mathrm{U}$ & \\
\hline 699-S28-E13A & Vinyl chloride & 8240_VOA_GCMS & 5/21/1996 12:36 PM & 10 & ug/L & $U$ & \\
\hline 699-S28-E13A & Vinyl chloride & 8260_VOA_GCMS & 5/22/1997 11:53 AM & 1 & $u g / L$ & $U$ & \\
\hline 699-S28-E13A & Vinyl chloride & 8260_VOA_GCMS & 6/19/1998 1:17 PM & 0.68 & ug/L & U & \\
\hline 699-S28-E13A & Vinyl chloride & 8260_VOA_GCMS & 6/14/1999 9:26 AM & 0.1 & $u g / L$ & $U$ & \\
\hline 699-S28-E13A & Vinyl chloride & 8260_VOA_GCMS & 10/11/2000 11:19 AM & 0.17 & ug/L & $\mathrm{U}$ & \\
\hline 699-S28-E13A & Vinyl chloride & 8260_VOA_GCMS & 4/30/2001 12:04 PM & 0.17 & $u g / L$ & $U$ & \\
\hline 699-S28-E13A & Vinyl chloride & 8260_VOA_GCMS & $7 / 25 / 2002$ 10:54 AM & 0.32 & ug/L & $U$ & \\
\hline 699-S28-E13A & Vinyl chloride & 8260_VOA_GCMS & $7 / 17 / 2003$ 11:20 AM & 0.25 & ug/L & $\mathrm{U}$ & \\
\hline 699-S28-E13A & Vinyl chloride & 8260_VOA_GCMS & 7/13/2004 10:57 AM & 0.08 & ug/L & $U$ & \\
\hline 699-S28-E13A & Vinyl chloride & 8260_VOA_GCMS & 9/29/2005 9:08 AM & 0.07 & ug/L & $\mathrm{U}$ & \\
\hline 699-S28-E13A & Vinyl chloride & 8260_VOA_GCMS & $8 / 31 / 2006$ 11:20 AM & 0.23 & ug/L & $U$ & \\
\hline 699-S29-E10A & Vinyl chloride & 8240_VOA_GCMS & 5/20/1996 11:04 AM & 10 & ug/L & $\mathrm{U}$ & \\
\hline 699-S29-E10A & Vinyl chloride & 8260_VOA_GCMS & 5/22/1997 9:44 AM & 1 & ug/L & U & \\
\hline 699-S29-E10A & Vinyl chloride & 8260_VOA_GCMS & 6/22/1998 12:39 PM & 0.68 & $\mathrm{ug} / \mathrm{L}$ & $\mathrm{U}$ & \\
\hline 699-S29-E10A & Vinyl chloride & 8260_VOA_GCMS & 6/14/1999 10:44 AM & 0.1 & ug/L & $\mathrm{U}$ & \\
\hline 699-S29-E10A & Vinyl chloride & 8260_VOA_GCMS & 10/11/2000 8:00 AM & 0.17 & $u g / L$ & U & \\
\hline 699-S29-E10A & Vinyl chloride & 8260_VOA_GCMS & 5/2/2001 9:05 AM & 0.17 & $u g / L$ & $U$ & \\
\hline 699-S29-E10A & Vinyl chloride & 8260_VOA_GCMS & 5/2/2001 9:05 AM & 0.17 & $u g / L$ & U & \\
\hline 699-S29-E10A & Vinyl chloride & 8260_VOA_GCMS & $7 / 25 / 2002$ 11:35 AM & 0.32 & ug/L & $U$ & \\
\hline 699-S29-E10A & Vinyl chloride & 8260_VOA_GCMS & 7/17/2003 1:08 PM & 0.25 & ug/L & $U$ & \\
\hline 699-S29-E10A & Vinyl chloride & 8260_VOA_GCMS & 7/13/2004 12:28 PM & 0.08 & $\mathrm{ug} / \mathrm{L}$ & U & \\
\hline 699-S29-E10A & Vinyl chloride & 8260_VOA_GCMS & 9/29/2005 11:23 AM & 0.07 & ug/L & $\mathrm{U}$ & \\
\hline 699-S29-E10A & Vinyl chloride & 8260_VOA_GCMS & 11/30/2006 11:10 AM & 0.23 & $\mathrm{ug} / \mathrm{L}$ & U & \\
\hline 699-S29-E11 & Vinyl chloride & CLP_VOA_GCMS & 6/27/1991 12:45 PM & 10 & $u g / L$ & $\mathrm{U}$ & \\
\hline 699-S29-E11 & Vinyl chloride & CLP_VOA_GCMS & 8/13/1991 11:11 AM & 10 & ug/L & $U$ & \\
\hline 699-S29-E11 & Vinyl chloride & CLP_VOA_GCMS & 9/17/1991 10:55 AM & 10 & ug/L & U & \\
\hline 699-S29-E11 & Vinyl chloride & CLP_VOA_GCMS & 11/21/1991 10:17 AM & 10 & $u g / L$ & U & \\
\hline 699-S29-E11 & Vinyl chloride & 8260_VOA_GCMS & 9/16/1992 9:35 AM & 1 & ug/L & U & \\
\hline 699-S29-E11 & Vinyl chloride & 8240_VOA_GCMS & 12/9/1992 10:02 AM & 10 & $\mathrm{ug} / \mathrm{L}$ & UJ & \\
\hline
\end{tabular}




\begin{tabular}{|c|c|c|c|c|c|c|c|}
\hline Well Name & Constituent & Method Name & Sample Date/Time & Value & Units & \begin{tabular}{|c|} 
Lab \\
Qualifier \\
\end{tabular} & $\begin{array}{c}\text { Review } \\
\text { Qualifier } \\
\end{array}$ \\
\hline 699-S29-E11 & Vinyl chloride & 8240_VOA_GCMS & $3 / 17 / 1993$ 11:23 AM & 10 & ug/L & $U$ & \\
\hline 699-S29-E11 & Vinyl chloride & 8260_VOA_GCMS & 6/9/1993 6:16 AM & 10 & $\mathrm{ug} / \mathrm{L}$ & $U$ & \\
\hline 699-S29-E11 & Vinyl chloride & 8240_VOA_GCMS & 9/22/1993 12:00 PM & 10 & $\mathrm{ug} / \mathrm{L}$ & $\mathrm{U}$ & \\
\hline 699-S29-E11 & Vinyl chloride & 8260_VOA_GCMS & 12/1/1993 11:40 AM & 1 & $\mathrm{ug} / \mathrm{L}$ & $\mathrm{U}$ & \\
\hline 699-S29-E11 & Vinyl chloride & 8260_VOA_GCMS & 3/23/1994 9:07 AM & 1 & $\mathrm{ug} / \mathrm{L}$ & $U$ & \\
\hline 699-S29-E11 & Vinyl chloride & 8260_VOA_GCMS & 10/11/1994 9:11 AM & 1 & $\mathrm{ug} / \mathrm{L}$ & $U$ & \\
\hline 699-S29-E11 & Vinyl chloride & 8260_VOA_GCMS & 10/11/1994 9:45 AM & 1 & ug/L & U & \\
\hline 699-S29-E11 & Vinyl chloride & 8260_VOA_GCMS & 4/10/1995 11:00 AM & 3 & $\mathrm{ug} / \mathrm{L}$ & & \\
\hline 699-S29-E11 & Vinyl chloride & 8010_VOA_GC & 3/4/1996 9:05 AM & 0.25 & $\mathrm{ug} / \mathrm{L}$ & $\mathrm{U}$ & \\
\hline 699-S29-E11 & Vinyl chloride & 8240_VOA_GCMS & 5/24/1996 12:15 PM & 10 & $\mathrm{ug} / \mathrm{L}$ & $U$ & \\
\hline 699-S29-E11 & Vinyl chloride & 8010_VOA_GC & 1/20/1997 10:54 AM & 1 & $\mathrm{ug} / \mathrm{L}$ & $U$ & \\
\hline 699-S29-E11 & Vinyl chloride & 8260_VOA_GCMS & 1/19/1998 9:22 AM & 0.68 & ug/L & $U$ & \\
\hline 699-S29-E11 & Vinyl chloride & 8260_VOA_GCMS & 1/20/1999 11:38 AM & 0.3 & $\mathrm{ug} / \mathrm{L}$ & $\mathrm{BJ}$ & \\
\hline 699-S29-E11 & Vinyl chloride & 8260_VOA_GCMS & 5/2/2001 12:51 PM & 0.17 & $\mathrm{ug} / \mathrm{L}$ & $U$ & \\
\hline 699-S29-E11 & Vinyl chloride & 8260_VOA_GCMS & 7/25/2002 12:16 PM & 0.32 & ug/L & $U$ & \\
\hline 699-S29-E11 & Vinyl chloride & 8260_VOA_GCMS & 7/25/2002 12:16 PM & 0.32 & $u g / L$ & $\mathrm{U}$ & \\
\hline 699-S29-E11 & Vinyl chloride & 8260_VOA_GCMS & 7/17/2003 12:24 PM & 0.25 & $\mathrm{ug} / \mathrm{L}$ & $U$ & \\
\hline 699-S29-E11 & Vinyl chloride & 8260_VOA_GCMS & $7 / 13 / 2004$ 11:45 AM & 0.08 & $\mathrm{ug} / \mathrm{L}$ & $\mathrm{U}$ & \\
\hline 699-S29-E11 & Vinyl chloride & 8260_VOA_GCMS & 7/14/2005 11:54 AM & 0.07 & $\mathrm{ug} / \mathrm{L}$ & U & \\
\hline 699-S29-E11 & Vinyl chloride & 8260_VOA_GCMS & 12/27/2006 1:20 PM & 0.23 & $\mathrm{ug} / \mathrm{L}$ & $U$ & \\
\hline 699-S29-E12 & Vinyl chloride & 8240_VOA_GCMS & 1/17/1989 12:00 AM & 10 & ug/L & $U$ & \\
\hline 699-S29-E12 & Vinyl chloride & 8240_VOA_GCMS & 5/24/1989 12:00 AM & 10 & $\mathrm{ug} / \mathrm{L}$ & $U$ & \\
\hline 699-S29-E12 & Vinyl chloride & CLP_VOA_GCMS & 5/23/1990 9:08 AM & 2 & ug/L & U & \\
\hline 699-S29-E12 & Vinyl chloride & CLP_VOA_GCMS & 8/22/1990 1:38 PM & 2 & $\mathrm{ug} / \mathrm{L}$ & $\mathrm{U}$ & \\
\hline 699-S29-E12 & Vinyl chloride & CLP_VOA_GCMS & 11/29/1990 10:25 AM & 1 & $u g / L$ & $U$ & \\
\hline 699-S29-E12 & Vinyl chloride & CLP_VOA_GCMS & 6/6/1991 1:31 PM & 10 & ug/L & U & \\
\hline 699-S29-E12 & Vinyl chloride & CLP_VOA_GCMS & 11/18/1991 12:55 PM & 10 & $\mathrm{ug} / \mathrm{L}$ & U & \\
\hline 699-S29-E12 & Vinyl chloride & 8260_VOA_GCMS & 5/14/1992 9:19 AM & 1 & $\mathrm{ug} / \mathrm{L}$ & $\mathrm{U}$ & \\
\hline 699-S29-E12 & Vinyl chloride & 8260_VOA_GCMS & 9/15/1992 5:40 AM & 1 & $\mathrm{ug} / \mathrm{L}$ & $U$ & \\
\hline 699-S29-E12 & Vinyl chloride & 8240_VOA_GCMS & 12/9/1992 10:58 AM & 10 & $\mathrm{ug} / \mathrm{L}$ & $U$ & \\
\hline 699-S29-E12 & Vinyl chloride & 8240_VOA_GCMS & 3/17/1993 9:31 AM & 10 & ug/L & U & \\
\hline 699-S29-E12 & Vinyl chloride & 8260_VOA_GCMS & 6/9/1993 5:25 AM & 10 & $\mathrm{ug} / \mathrm{L}$ & $U$ & \\
\hline 699-S29-E12 & Vinyl chloride & 8240_VOA_GCMS & 9/22/1993 9:00 AM & 10 & $\mathrm{ug} / \mathrm{L}$ & $\mathrm{U}$ & \\
\hline 699-S29-E12 & Vinyl chloride & 8260_VOA_GCMS & 12/1/1993 9:30 AM & 1 & $\mathrm{ug} / \mathrm{L}$ & $U$ & \\
\hline 699-S29-E12 & Vinyl chloride & 8260_VOA_GCMS & 3/22/1994 12:45 PM & 1 & $u g / L$ & $U$ & \\
\hline 699-S29-E12 & Vinyl chloride & 8260_VOA_GCMS & 6/8/1994 10:40 AM & 0.5 & $\mathrm{ug} / \mathrm{L}$ & $\mathrm{U}$ & \\
\hline 699-S29-E12 & Vinyl chloride & 8260_VOA_GCMS & 10/12/1994 12:15 PM & 1 & ug/L & $\mathrm{U}$ & \\
\hline 699-S29-E12 & Vinyl chloride & 8260_VOA_GCMS & 4/11/1995 12:00 PM & 3 & $\mathrm{ug} / \mathrm{L}$ & $\mathrm{U}$ & \\
\hline 699-S29-E12 & Vinyl chloride & 8260_VOA_GCMS & 4/11/1995 1:15 PM & 3 & $\mathrm{ug} / \mathrm{L}$ & $U$ & \\
\hline 699-S29-E12 & Vinyl chloride & 8010_VOA_GC & 1/15/1996 9:10 AM & 0.25 & $\mathrm{ug} / \mathrm{L}$ & $\mathrm{U}$ & \\
\hline 699-S29-E12 & Vinyl chloride & 8240_VOA_GCMS & 5/20/1996 12:47 PM & 10 & $\mathrm{ug} / \mathrm{L}$ & U & \\
\hline 699-S29-E12 & Vinyl chloride & 8010_VOA_GC & 1/16/1997 9:20 AM & 1 & $\mathrm{ug} / \mathrm{L}$ & $\mathrm{U}$ & \\
\hline \begin{tabular}{|l|}
$699-S 29-E 12$ \\
\end{tabular} & Vinyl chloride & 8010_VOA_GC & 1/16/1997 9:20 AM & 1 & ug/L & $\mathrm{U}$ & \\
\hline 699-S29-E12 & Vinyl chloride & 8260_VOA_GCMS & 1/12/1998 12:23 PM & 0.68 & ug/L & U & \\
\hline 699-S29-E12 & Vinyl chloride & 8260_VOA_GCMS & 1/20/1999 9:17 AM & 0.2 & ug/L & $\mathrm{BJ}$ & \\
\hline 699-S29-E12 & Vinyl chloride & 8260_VOA_GCMS & 7/25/2002 9:45 AM & 0.32 & $u g / L$ & U & \\
\hline 699-S29-E12 & Vinyl chloride & 8260_VOA_GCMS & 7/21/2003 12:10 PM & 0.25 & $\mathrm{ug} / \mathrm{L}$ & $U$ & \\
\hline 699-S29-E12 & Vinyl chloride & 8260_VOA_GCMS & $7 / 13 / 2004$ 10:01 AM & 0.08 & ug/L & $U$ & \\
\hline 699-S29-E12 & Vinyl chloride & 8260_VOA_GCMS & 11/18/2005 10:51 AM & 0.07 & ug/L & U & \\
\hline 699-S29-E12 & Vinyl chloride & 8260_VOA_GCMS & 11/6/2006 1:32 PM & 0.23 & ug/L & $\mathrm{U}$ & \\
\hline 699-S29-E13A & Vinyl chloride & 8240_VOA_GCMS & 5/24/1996 12:00 AM & 10 & $\mathrm{ug} / \mathrm{L}$ & U & \\
\hline 699-S29-E13A & Vinyl chloride & 8260_VOA_GCMS & 5/22/1997 11:18 AM & 1 & ug/L & $\mathrm{U}$ & \\
\hline 699-S29-E13A & Vinyl chloride & 8260_VOA_GCMS & 6/24/1998 8:37 AM & 0.68 & ug/L & $U$ & \\
\hline 699-S29-E13A & Vinyl chloride & 8260_VOA_GCMS & 6/15/1999 8:27 AM & 0.1 & ug/L & U & \\
\hline 699-S29-E13A & Vinyl chloride & 8260_VOA_GCMS & 6/15/1999 8:27 AM & 0.1 & ug/L & U & \\
\hline 699-S29-E13A & Vinyl chloride & 8260_VOA_GCMS & 10/11/2000 12:38 PM & 0.17 & ug/L & U & \\
\hline 699-S29-E13A & Vinyl chloride & 8260_VOA_GCMS & 10/11/2000 12:38 PM & 0.17 & $\mathrm{ug} / \mathrm{L}$ & $\mathrm{U}$ & \\
\hline
\end{tabular}




\begin{tabular}{|c|c|c|c|c|c|c|c|}
\hline Well Name & Constituent & Method Name & Sample Date/Time & Value & Units & $\begin{array}{c}\text { Lab } \\
\text { Qualifier } \\
\end{array}$ & $\begin{array}{c}\text { Review } \\
\text { Qualifier } \\
\end{array}$ \\
\hline 699-S29-E13A & Vinyl chloride & 8260_VOA_GCMS & 5/2/2001 10:46 AM & 0.17 & ug/L & $U$ & \\
\hline 699-S29-E13A & Vinyl chloride & 8260_VOA_GCMS & $7 / 25 / 2002$ 10:17 AM & 0.32 & $\mathrm{ug} / \mathrm{L}$ & $\mathrm{U}$ & \\
\hline 699-S29-E13A & Vinyl chloride & 8260_VOA_GCMS & $7 / 22 / 2003$ 12:34 PM & 0.25 & $\mathrm{ug} / \mathrm{L}$ & $\mathrm{U}$ & \\
\hline 699-S29-E13A & Vinyl chloride & 8260_VOA_GCMS & $7 / 14 / 2004$ 11:47 AM & 0.08 & $\mathrm{ug} / \mathrm{L}$ & $\mathrm{U}$ & \\
\hline 699-S29-E13A & Vinyl chloride & 8260_VOA_GCMS & 9/29/2005 12:40 PM & 0.07 & $\mathrm{ug} / \mathrm{L}$ & $U$ & \\
\hline 699-S29-E13A & Vinyl chloride & 8260_VOA_GCMS & $11 / 6 / 2006$ 11:18 AM & 0.23 & $\mathrm{ug} / \mathrm{L}$ & $U$ & \\
\hline 699-S30-E10A & Vinyl chloride & CLP_VOA_GCMS & 2/6/1990 10:06 AM & 2 & $\mathrm{ug} / \mathrm{L}$ & U & \\
\hline 699-S30-E10A & Vinyl chloride & CLP_VOA_GCMS & 5/14/1990 1:32 PM & 2 & ug/L & $U$ & \\
\hline 699-S30-E10A & Vinyl chloride & CLP_VOA_GCMS & 8/27/1990 12:23 PM & 2 & ug/L & $U$ & \\
\hline 699-S30-E10A & Vinyl chloride & CLP_VOA_GCMS & 11/28/1990 9:02 AM & & ug/L & $U$ & \\
\hline 699-S30-E10A & Vinyl chloride & CLP_VOA_GCMS & 11/28/1990 9:02 AM & 1 & $\mathrm{ug} / \mathrm{L}$ & $U$ & \\
\hline 699-S30-E10A & Vinyl chloride & CLP_VOA_GCMS & 3/15/1991 8:35 AM & 10 & $\mathrm{ug} / \mathrm{L}$ & $U$ & \\
\hline 699-S30-E10A & Vinyl chloride & CLP_VOA_GCMS & 6/5/1991 1:03 PM & 10 & $\mathrm{ug} / \mathrm{L}$ & U & \\
\hline 699-S30-E10A & Vinyl chloride & CLP_VOA_GCMS & 6/5/1991 1:03 PM & 10 & $\mathrm{ug} / \mathrm{L}$ & $\mathrm{U}$ & \\
\hline 699-S30-E10A & Vinyl chloride & CLP_VOA_GCMS & $8 / 14 / 1991$ 7:58 AM & 10 & $\mathrm{ug} / \mathrm{L}$ & $U$ & \\
\hline 699-S30-E10A & Vinyl chloride & CLP_VOA_GCMS & 9/17/1991 11:53 AM & 10 & ug/L & $\mathrm{U}$ & \\
\hline 699-S30-E10A & Vinyl chloride & CLP_VOA_GCMS & 11/13/1991 9:23 AM & 10 & $\mathrm{ug} / \mathrm{L}$ & $U$ & \\
\hline 699-S30-E10A & Vinyl chloride & 8260_VOA_GCMS & 5/13/1992 8:57 AM & 1 & $\mathrm{ug} / \mathrm{L}$ & $U$ & \\
\hline 699-S30-E10A & Vinyl chloride & 8260_VOA_GCMS & 9/14/1992 9:00 AM & 1 & $\mathrm{ug} / \mathrm{L}$ & U & \\
\hline 699-S30-E10A & Vinyl chloride & 8240_VOA_GCMS & 12/7/1992 11:05 AM & 10 & $\mathrm{ug} / \mathrm{L}$ & $U$ & \\
\hline 699-S30-E10A & Vinyl chloride & 8240_VOA_GCMS & 3/15/1993 11:14 AM & 10 & ug/L & UJ & \\
\hline 699-S30-E10A & Vinyl chloride & 8260_VOA_GCMS & 6/7/1993 10:07 AM & 10 & $\mathrm{ug} / \mathrm{L}$ & $U$ & \\
\hline 699-S30-E10A & Vinyl chloride & 8240_VOA_GCMS & 9/23/1993 9:00 AM & 10 & $\mathrm{ug} / \mathrm{L}$ & U & \\
\hline 699-S30-E10A & Vinyl chloride & 8260_VOA_GCMS & 12/2/1993 9:00 AM & 1 & $\mathrm{ug} / \mathrm{L}$ & $\mathrm{U}$ & \\
\hline 699-S30-E10A & Vinyl chloride & 8260_VOA_GCMS & 3/21/1994 12:25 PM & 1 & ug/L & $\mathrm{U}$ & \\
\hline 699-S30-E10A & Vinyl chloride & 8260_VOA_GCMS & 6/6/1994 12:00 PM & 0.5 & $\mathrm{ug} / \mathrm{L}$ & UJ & \\
\hline 699-S30-E10A & Vinyl chloride & 8260_VOA_GCMS & 10/11/1994 1:15 PM & 1 & $\mathrm{ug} / \mathrm{L}$ & $U$ & \\
\hline 699-S30-E10A & Vinyl chloride & 8260_VOA_GCMS & 4/10/1995 11:43 AM & 3 & $\mathrm{ug} / \mathrm{L}$ & & \\
\hline 699-S30-E10A & Vinyl chloride & 8010_VOA_GC & 1/12/1996 1:00 PM & 0.25 & $\mathrm{ug} / \mathrm{L}$ & $U$ & \\
\hline 699-S30-E10A & Vinyl chloride & 8240_VOA_GCMS & 5/22/1996 9:06 AM & 5 & $\mathrm{ug} / \mathrm{L}$ & $U$ & \\
\hline 699-S30-E10A & Vinyl chloride & 8240_VOA_GCMS & 5/22/1996 9:06 AM & 10 & ug/L & U & \\
\hline 699-S30-E10A & Vinyl chloride & 8240_VOA_GCMS & 5/22/1996 9:06 AM & 10 & $\mathrm{ug} / \mathrm{L}$ & $U$ & \\
\hline 699-S30-E10A & Vinyl chloride & 8260_VOA_GCMS & 5/22/1997 11:08 AM & 1 & $\mathrm{ug} / \mathrm{L}$ & $\mathrm{U}$ & \\
\hline 699-S30-E10A & Vinyl chloride & 8260_VOA_GCMS & 6/22/1998 11:18 AM & 0.68 & $\mathrm{ug} / \mathrm{L}$ & $U$ & \\
\hline 699-S30-E10A & Vinyl chloride & 8260_VOA_GCMS & 6/22/1998 11:18 AM & 0.68 & $\mathrm{ug} / \mathrm{L}$ & $U$ & \\
\hline 699-S30-E10A & Vinyl chloride & 8260_VOA_GCMS & 6/14/1999 12:27 PM & 0.1 & $u g / L$ & $\mathrm{U}$ & \\
\hline 699-S30-E10A & Vinyl chloride & 8260_VOA_GCMS & 10/11/2000 12:09 PM & 0.17 & ug/L & $\mathrm{U}$ & \\
\hline 699-S30-E10A & Vinyl chloride & 8260_VOA_GCMS & 5/1/2001 11:45 AM & 0.17 & $\mathrm{ug} / \mathrm{L}$ & $\mathrm{U}$ & \\
\hline 699-S30-E10A & Vinyl chloride & 8260_VOA_GCMS & 7/31/2002 10:49 AM & 0.32 & ug/L & $U$ & \\
\hline 699-S30-E10A & Vinyl chloride & 8260_VOA_GCMS & 7/22/2003 9:55 AM & 0.25 & ug/L & $\mathrm{U}$ & \\
\hline 699-S30-E10A & Vinyl chloride & 8260_VOA_GCMS & 7/15/2004 11:12 AM & 0.08 & $\mathrm{ug} / \mathrm{L}$ & U & \\
\hline 699-S30-E10A & Vinyl chloride & 8260_VOA_GCMS & 7/14/2005 11:32 AM & 0.07 & $\mathrm{ug} / \mathrm{L}$ & $\mathrm{U}$ & \\
\hline 699-S30-E10A & Vinyl chloride & 8260_VOA_GCMS & 11/6/2006 12:11 PM & 0.23 & ug/L & $\mathrm{U}$ & \\
\hline 699-S30-E10B & Vinyl chloride & CLP_VOA_GCMS & 2/6/1990 8:22 AM & 2 & $u g / L$ & U & \\
\hline 699-S30-E10B & Vinyl chloride & CLP_VOA_GCMS & 2/6/1990 8:22 AM & 2 & ug/L & $U$ & \\
\hline 699-S30-E10B & Vinyl chloride & CLP_VOA_GCMS & 5/15/1990 8:42 AM & 2 & ug/L & $U$ & \\
\hline 699-S30-E10B & Vinyl chloride & CLP_VOA_GCMS & 8/27/1990 1:36 PM & 2 & ug/L & $U$ & \\
\hline 699-S30-E10B & Vinyl chloride & CLP_VOA_GCMS & 11/28/1990 11:16 AM & 10 & ug/L & $U$ & \\
\hline 699-S30-E10B & Vinyl chloride & CLP_VOA_GCMS & 11/28/1990 11:16 AM & 1 & ug/L & U & \\
\hline 699-S30-E10B & Vinyl chloride & CLP_VOA_GCMS & 3/15/1991 9:34 AM & 10 & ug/L & $\mathrm{U}$ & \\
\hline 699-S30-E10B & Vinyl chloride & CLP_VOA_GCMS & 3/15/1991 9:34 AM & 10 & ug/L & U & \\
\hline 699-S30-E10B & Vinyl chloride & CLP_VOA_GCMS & 6/5/1991 1:42 PM & 10 & $u g / L$ & $\mathrm{U}$ & \\
\hline 699-S30-E10B & Vinyl chloride & CLP_VOA_GCMS & 6/5/1991 1:42 PM & 10 & ug/L & $U$ & \\
\hline 699-S30-E10B & Vinyl chloride & CLP_VOA_GCMS & 8/14/1991 6:55 AM & 10 & ug/L & U & \\
\hline 699-S30-E10B & Vinyl chloride & CLP_VOA_GCMS & 8/14/1991 6:55 AM & 10 & $u g / L$ & U & \\
\hline 699-S30-E10B & Vinyl chloride & CLP_VOA_GCMS & 8/14/1991 6:55 AM & 10 & ug/L & U & \\
\hline 699-S30-E10B & Vinyl chloride & CLP_VOA_GCMS & 9/17/1991 12:37 PM & 10 & ug/L & U & \\
\hline
\end{tabular}




\begin{tabular}{|c|c|c|c|c|c|c|c|}
\hline Well Name & Constituent & Method Name & Sample Date/Time & Value & Units & $\begin{array}{c}\text { Lab } \\
\text { Qualifier } \\
\end{array}$ & $\begin{array}{c}\text { Review } \\
\text { Qualifier } \\
\end{array}$ \\
\hline 699-S30-E10B & Vinyl chloride & CLP_VOA_GCMS & 11/13/1991 10:21 AM & 10 & ug/L & $U$ & \\
\hline 699-S30-E10B & Vinyl chloride & 8260_VOA_GCMS & 5/13/1992 9:50 AM & 1 & $\mathrm{ug} / \mathrm{L}$ & $\mathrm{U}$ & \\
\hline 699-S30-E10B & Vinyl chloride & 8260_VOA_GCMS & 9/14/1992 10:00 AM & 1 & $\mathrm{ug} / \mathrm{L}$ & $\mathrm{U}$ & \\
\hline 699-S30-E10B & Vinyl chloride & 8240_VOA_GCMS & 12/7/1992 11:45 AM & 10 & $\mathrm{ug} / \mathrm{L}$ & $\mathrm{U}$ & \\
\hline 699-S30-E10B & Vinyl chloride & 8240_VOA_GCMS & 3/15/1993 10:38 AM & 10 & $\mathrm{ug} / \mathrm{L}$ & UJ & \\
\hline 699-S30-E10B & Vinyl chloride & 8260_VOA_GCMS & 6/7/1993 10:47 AM & 10 & $\mathrm{ug} / \mathrm{L}$ & $U$ & \\
\hline 699-S30-E10B & Vinyl chloride & 8240_VOA_GCMS & 9/23/1993 9:42 AM & 10 & $\mathrm{ug} / \mathrm{L}$ & U & \\
\hline 699-S30-E10B & Vinyl chloride & 8260_VOA_GCMS & 12/2/1993 9:40 AM & 1 & $\mathrm{ug} / \mathrm{L}$ & $U$ & \\
\hline 699-S30-E10B & Vinyl chloride & 8260_VOA_GCMS & 3/21/1994 11:15 AM & 1 & $\mathrm{ug} / \mathrm{L}$ & $U$ & \\
\hline 699-S30-E10B & Vinyl chloride & 8260_VOA_GCMS & 6/6/1994 1:25 AM & 0.5 & $\mathrm{ug} / \mathrm{L}$ & $U$ & \\
\hline 699-S30-E10B & Vinyl chloride & 8260_VOA_GCMS & 10/11/1994 12:40 PM & 1 & $\mathrm{ug} / \mathrm{L}$ & $U$ & \\
\hline 699-S30-E10B & Vinyl chloride & 8260_VOA_GCMS & 4/10/1995 12:30 PM & 3 & $\mathrm{ug} / \mathrm{L}$ & & \\
\hline 699-S30-E10B & Vinyl chloride & 8240_VOA_GCMS & 5/22/1996 10:25 AM & 5 & $\mathrm{ug} / \mathrm{L}$ & U & \\
\hline 699-S30-E10B & Vinyl chloride & 8240_VOA_GCMS & 5/22/1996 10:25 AM & 10 & $\mathrm{ug} / \mathrm{L}$ & $\mathrm{U}$ & \\
\hline 699-S30-E10B & Vinyl chloride & 8240_VOA_GCMS & 5/22/1996 10:25 AM & 10 & $\mathrm{ug} / \mathrm{L}$ & $U$ & \\
\hline 699-S30-E10B & Vinyl chloride & 8010_VOA_GC & 1/20/1997 11:26 AM & 1 & $u g / L$ & $\mathrm{U}$ & \\
\hline 699-S30-E10B & Vinyl chloride & 8260_VOA_GCMS & 1/20/1998 9:40 AM & 0.68 & $\mathrm{ug} / \mathrm{L}$ & $\mathrm{U}$ & \\
\hline 699-S30-E10B & Vinyl chloride & 8260_VOA_GCMS & 1/20/1998 9:40 AM & 0.68 & $\mathrm{ug} / \mathrm{L}$ & $\mathrm{U}$ & \\
\hline 699-S30-E10B & Vinyl chloride & 8260_VOA_GCMS & 1/20/1999 12:21 PM & 0.2 & $\mathrm{ug} / \mathrm{L}$ & $\mathrm{BJ}$ & \\
\hline 699-S30-E10B & Vinyl chloride & 8260_VOA_GCMS & 5/2/2001 10:05 AM & 0.17 & $\mathrm{ug} / \mathrm{L}$ & $U$ & \\
\hline 699-S30-E10B & Vinyl chloride & 8260_VOA_GCMS & 7/31/2002 10:13 AM & 0.32 & ug/L & $U$ & \\
\hline 699-S30-E10B & Vinyl chloride & 8260_VOA_GCMS & 7/21/2003 12:15 PM & 0.25 & $\mathrm{ug} / \mathrm{L}$ & $U$ & \\
\hline 699-S30-E10B & Vinyl chloride & 8260_VOA_GCMS & 7/15/2004 10:35 AM & 0.08 & $\mathrm{ug} / \mathrm{L}$ & U & \\
\hline 699-S30-E10B & Vinyl chloride & 8260_VOA_GCMS & 7/25/2005 11:00 AM & 0.07 & $\mathrm{ug} / \mathrm{L}$ & $\mathrm{U}$ & \\
\hline 699-S30-E10B & Vinyl chloride & 8260_VOA_GCMS & 11/6/2006 12:53 PM & 0.23 & $\mathrm{ug} / \mathrm{L}$ & $\mathrm{U}$ & \\
\hline 699-S30-E11A & Vinyl chloride & 8240_VOA_GCMS & 5/20/1996 9:20 AM & 10 & ug/L & $\mathrm{U}$ & \\
\hline 699-S30-E11A & Vinyl chloride & 8260_VOA_GCMS & 5/22/1997 8:59 AM & 1 & $\mathrm{ug} / \mathrm{L}$ & U & \\
\hline 699-S30-E11A & Vinyl chloride & 8260_VOA_GCMS & 6/19/1998 12:40 PM & 0.68 & $\mathrm{ug} / \mathrm{L}$ & $\mathrm{U}$ & \\
\hline 699-S30-E11A & Vinyl chloride & 8260_VOA_GCMS & 6/14/1999 11:20 AM & 0.1 & $\mathrm{ug} / \mathrm{L}$ & $U$ & \\
\hline 699-S30-E11A & Vinyl chloride & 8260_VOA_GCMS & 10/11/2000 1:08 PM & 0.17 & $\mathrm{ug} / \mathrm{L}$ & $U$ & \\
\hline 699-S30-E11A & Vinyl chloride & 8260_VOA_GCMS & 5/1/2001 10:43 AM & 0.17 & ug/L & U & \\
\hline 699-S30-E11A & Vinyl chloride & 8260_VOA_GCMS & 7/25/2002 12:03 PM & 0.32 & $\mathrm{ug} / \mathrm{L}$ & $U$ & \\
\hline 699-S30-E11A & Vinyl chloride & 8260_VOA_GCMS & 9/10/2003 11:31 AM & 0.25 & $\mathrm{ug} / \mathrm{L}$ & $\mathrm{U}$ & \\
\hline 699-S30-E11A & Vinyl chloride & 8260_VOA_GCMS & 7/14/2004 11:55 AM & 0.08 & $\mathrm{ug} / \mathrm{L}$ & $U$ & \\
\hline 699-S30-E11A & Vinyl chloride & 8260_VOA_GCMS & 9/29/2005 11:50 AM & 0.07 & ug/L & $U$ & \\
\hline 699-S30-E11A & Vinyl chloride & 8260_VOA_GCMS & 11/6/2006 2:22 PM & 0.23 & $\mathrm{ug} / \mathrm{L}$ & $\mathrm{U}$ & \\
\hline 699-S31-E10A & Vinyl chloride & CLP_VOA_GCMS & 2/14/1990 4:01 PM & 2 & ug/L & U & \\
\hline 699-S31-E10A & Vinyl chloride & CLP_VOA_GCMS & 5/15/1990 10:06 AM & 2 & ug/L & $\mathrm{U}$ & \\
\hline 699-S31-E10A & Vinyl chloride & CLP_VOA_GCMS & 5/15/1990 10:06 AM & 2 & $\mathrm{ug} / \mathrm{L}$ & $U$ & \\
\hline 699-S31-E10A & Vinyl chloride & CLP_VOA_GCMS & 8/28/1990 9:00 AM & 2 & $u g / L$ & $\mathrm{U}$ & \\
\hline 699-S31-E10A & Vinyl chloride & CLP_VOA_GCMS & 8/28/1990 9:00 AM & 2 & $u g / L$ & U & \\
\hline 699-S31-E10A & Vinyl chloride & CLP_VOA_GCMS & 11/26/1990 11:58 AM & 1 & ug/L & $\mathrm{U}$ & \\
\hline 699-S31-E10A & Vinyl chloride & CLP_VOA_GCMS & 3/15/1991 11:03 AM & 10 & ug/L & $\mathrm{U}$ & \\
\hline 699-S31-E10A & Vinyl chloride & CLP_VOA_GCMS & 6/4/1991 9:02 AM & 10 & $u g / L$ & U & \\
\hline 699-S31-E10A & Vinyl chloride & CLP_VOA_GCMS & 8/12/1991 8:20 AM & 10 & ug/L & $U$ & \\
\hline 699-S31-E10A & Vinyl chloride & CLP_VOA_GCMS & 9/16/1991 11:01 AM & 10 & ug/L & U & \\
\hline 699-S31-E10A & Vinyl chloride & CLP_VOA_GCMS & 11/12/1991 8:38 AM & 10 & ug/L & $U$ & \\
\hline 699-S31-E10A & Vinyl chloride & 8240_VOA_GCMS & 3/10/1992 9:18 AM & 1 & $u g / L$ & $U$ & \\
\hline 699-S31-E10A & Vinyl chloride & CLP_VOA_GCMS & 3/10/1992 9:54 AM & 10 & ug/L & U & \\
\hline 699-S31-E10A & Vinyl chloride & 8240_VOA_GCMS & 3/10/1992 10:11 AM & 10 & ug/L & $\mathrm{U}$ & \\
\hline 699-S31-E10A & Vinyl chloride & 8240_VOA_GCMS & 5/11/1992 12:00 AM & 10 & $\mathrm{ug} / \mathrm{L}$ & U & \\
\hline 699-S31-E10A & Vinyl chloride & 8260_VOA_GCMS & 5/11/1992 12:03 PM & 1 & ug/L & $\mathrm{U}$ & \\
\hline 699-S31-E10A & Vinyl chloride & 8260_VOA_GCMS & 5/11/1992 12:03 PM & 1 & ug/L & $U$ & \\
\hline 699-S31-E10A & Vinyl chloride & 8260_VOA_GCMS & 9/14/1992 1:00 PM & 1 & ug/L & U & \\
\hline 699-S31-E10A & Vinyl chloride & 8260_VOA_GCMS & 9/14/1992 1:00 PM & 1 & ug/L & U & \\
\hline 699-S31-E10A & Vinyl chloride & 8240_VOA_GCMS & 12/8/1992 10:00 AM & 10 & $\mathrm{ug} / \mathrm{L}$ & U & \\
\hline 699-S31-E10A & Vinyl chloride & 8240_VOA_GCMS & 3/16/1993 8:56 AM & 10 & $\mathrm{ug} / \mathrm{L}$ & $\mathrm{U}$ & \\
\hline
\end{tabular}




\begin{tabular}{|c|c|c|c|c|c|c|c|}
\hline Well Name & Constituent & Method Name & Sample Date/Time & Value & Units & \begin{tabular}{|c|} 
Lab \\
Qualifier \\
\end{tabular} & $\begin{array}{c}\text { Review } \\
\text { Qualifier } \\
\end{array}$ \\
\hline 699-S31-E10A & Vinyl chloride & 8240_VOA_GCMS & 3/16/1993 9:10 AM & 10 & ug/L & $U$ & \\
\hline 699-S31-E10A & Vinyl chloride & 8260_VOA_GCMS & 6/8/1993 9:32 AM & 10 & $\mathrm{ug} / \mathrm{L}$ & $\mathrm{U}$ & \\
\hline 699-S31-E10A & Vinyl chloride & 8260_VOA_GCMS & 6/8/1993 9:32 AM & 10 & $\mathrm{ug} / \mathrm{L}$ & $\mathrm{U}$ & \\
\hline 699-S31-E10A & Vinyl chloride & 8240_VOA_GCMS & 9/22/1993 10:00 AM & 10 & $\mathrm{ug} / \mathrm{L}$ & $\mathrm{U}$ & \\
\hline 699-S31-E10A & Vinyl chloride & 8240_VOA_GCMS & 9/22/1993 10:00 AM & 10 & $\mathrm{ug} / \mathrm{L}$ & $U$ & \\
\hline 699-S31-E10A & Vinyl chloride & 8260_VOA_GCMS & 11/30/1993 10:40 AM & 5 & $\mathrm{ug} / \mathrm{L}$ & $U$ & \\
\hline 699-S31-E10A & Vinyl chloride & 8260_VOA_GCMS & 11/30/1993 10:40 AM & 1 & $\mathrm{ug} / \mathrm{L}$ & & \\
\hline 699-S31-E10A & Vinyl chloride & 8260_VOA_GCMS & 3/22/1994 9:50 AM & 0.5 & $\mathrm{ug} / \mathrm{L}$ & $U$ & \\
\hline 699-S31-E10A & Vinyl chloride & 8260_VOA_GCMS & 3/22/1994 9:50 AM & 1 & $\mathrm{ug} / \mathrm{L}$ & $U$ & \\
\hline 699-S31-E10A & Vinyl chloride & 8260_VOA_GCMS & 6/7/1994 9:46 AM & 0.5 & $\mathrm{ug} / \mathrm{L}$ & $U$ & \\
\hline 699-S31-E10A & Vinyl chloride & 8260_VOA_GCMS & 10/12/1994 10:15 AM & 1 & $\mathrm{ug} / \mathrm{L}$ & $U$ & \\
\hline 699-S31-E10A & Vinyl chloride & 8260_VOA_GCMS & 4/12/1995 9:30 AM & 1 & $\mathrm{ug} / \mathrm{L}$ & & \\
\hline 699-S31-E10A & Vinyl chloride & 8260_VOA_GCMS & 4/12/1995 9:30 AM & 3 & $\mathrm{ug} / \mathrm{L}$ & & \\
\hline 699-S31-E10A & Vinyl chloride & 8010_VOA_GC & 11/17/1995 12:00 PM & 0.25 & $\mathrm{ug} / \mathrm{L}$ & $U$ & \\
\hline 699-S31-E10A & Vinyl chloride & 8240_VOA_GCMS & 5/22/1996 11:17 AM & 10 & $\mathrm{ug} / \mathrm{L}$ & $U$ & \\
\hline 699-S31-E10A & Vinyl chloride & 8260_VOA_GCMS & 5/22/1997 12:07 PM & 1 & $u g / L$ & $\mathrm{U}$ & \\
\hline 699-S31-E10A & Vinyl chloride & 8260_VOA_GCMS & 6/22/1998 10:37 AM & 0.68 & $\mathrm{ug} / \mathrm{L}$ & $U$ & \\
\hline 699-S31-E10A & Vinyl chloride & 8260_VOA_GCMS & 6/22/1998 10:37 AM & 0.68 & $\mathrm{ug} / \mathrm{L}$ & $U$ & \\
\hline 699-S31-E10A & Vinyl chloride & 8260_VOA_GCMS & 6/14/1999 11:48 AM & 0.1 & $\mathrm{ug} / \mathrm{L}$ & U & \\
\hline 699-S31-E10A & Vinyl chloride & 8260_VOA_GCMS & 10/11/2000 11:21 AM & 0.17 & $\mathrm{ug} / \mathrm{L}$ & $U$ & \\
\hline 699-S31-E10A & Vinyl chloride & 8260_VOA_GCMS & 5/1/2001 11:13 AM & 0.17 & ug/L & $U$ & \\
\hline 699-S31-E10A & Vinyl chloride & 8260_VOA_GCMS & 7/26/2002 12:24 PM & 0.32 & $\mathrm{ug} / \mathrm{L}$ & U & \\
\hline 699-S31-E10A & Vinyl chloride & 8260_VOA_GCMS & $7 / 22 / 2003$ 10:16 AM & 0.25 & $\mathrm{ug} / \mathrm{L}$ & U & \\
\hline 699-S31-E10A & Vinyl chloride & 8260_VOA_GCMS & 7/14/2004 12:32 PM & 0.08 & $\mathrm{ug} / \mathrm{L}$ & $\mathrm{U}$ & \\
\hline 699-S31-E10A & Vinyl chloride & 8260_VOA_GCMS & 9/29/2005 9:21 AM & 0.07 & ug/L & $U$ & \\
\hline 699-S31-E10A & Vinyl chloride & 8260_VOA_GCMS & 3/29/2006 12:28 PM & 0.23 & $\mathrm{ug} / \mathrm{L}$ & $\mathrm{U}$ & \\
\hline 699-S31-E10C & Vinyl chloride & CLP_VOA_GCMS & 2/5/1990 10:58 AM & 2 & ug/L & UJ & \\
\hline 699-S31-E10C & Vinyl chloride & CLP_VOA_GCMS & 5/15/1990 2:02 PM & 2 & $\mathrm{ug} / \mathrm{L}$ & $U$ & \\
\hline 699-S31-E10C & Vinyl chloride & CLP_VOA_GCMS & 8/28/1990 10:18 AM & 2 & $\mathrm{ug} / \mathrm{L}$ & $U$ & \\
\hline 699-S31-E10C & Vinyl chloride & CLP_VOA_GCMS & 11/27/1990 12:31 PM & 1 & $\mathrm{ug} / \mathrm{L}$ & $U$ & \\
\hline 699-S31-E10C & Vinyl chloride & CLP_VOA_GCMS & 3/15/1991 12:36 PM & 10 & ug/L & U & \\
\hline 699-S31-E10C & Vinyl chloride & CLP_VOA_GCMS & 6/4/1991 12:39 PM & 10 & $\mathrm{ug} / \mathrm{L}$ & $U$ & \\
\hline 699-S31-E10C & Vinyl chloride & CLP_VOA_GCMS & 8/12/1991 10:05 AM & 10 & $\mathrm{ug} / \mathrm{L}$ & $\mathrm{U}$ & \\
\hline 699-S31-E10C & Vinyl chloride & CLP_VOA_GCMS & 9/16/1991 9:35 AM & 10 & $\mathrm{ug} / \mathrm{L}$ & $U$ & \\
\hline 699-S31-E10C & Vinyl chloride & CLP_VOA_GCMS & 11/12/1991 10:16 AM & 10 & $\mathrm{ug} / \mathrm{L}$ & $U$ & \\
\hline 699-S31-E10C & Vinyl chloride & 8240_VOA_GCMS & $3 / 10 / 1992$ 11:36 AM & 10 & ug/L & $\mathrm{U}$ & \\
\hline 699-S31-E10C & Vinyl chloride & 8240_VOA_GCMS & 3/10/1992 11:49 AM & 1 & ug/L & U & \\
\hline 699-S31-E10C & Vinyl chloride & 8240_VOA_GCMS & 3/10/1992 11:58 AM & 10 & $\mathrm{ug} / \mathrm{L}$ & $\mathrm{U}$ & \\
\hline 699-S31-E10C & Vinyl chloride & 8240_VOA_GCMS & 5/12/1992 12:00 AM & 10 & $\mathrm{ug} / \mathrm{L}$ & $U$ & \\
\hline 699-S31-E10C & Vinyl chloride & 8260_VOA_GCMS & 5/12/1992 10:27 AM & 1 & $u g / L$ & $\mathrm{U}$ & \\
\hline 699-S31-E10C & Vinyl chloride & 8260_VOA_GCMS & 5/12/1992 10:27 AM & 1 & $\mathrm{ug} / \mathrm{L}$ & U & \\
\hline 699-S31-E10C & Vinyl chloride & 8260_VOA_GCMS & 9/14/1992 10:55 AM & 1 & $\mathrm{ug} / \mathrm{L}$ & $\mathrm{U}$ & \\
\hline 699-S31-E10C & Vinyl chloride & 8260_VOA_GCMS & 9/14/1992 10:55 AM & 1 & ug/L & $\mathrm{U}$ & \\
\hline 699-S31-E10C & Vinyl chloride & 8240_VOA_GCMS & 12/7/1992 9:58 AM & 10 & $u g / L$ & U & \\
\hline 699-S31-E10C & Vinyl chloride & 8240_VOA_GCMS & 3/15/1993 9:53 AM & 10 & ug/L & UJ & \\
\hline 699-S31-E10C & Vinyl chloride & 8260_VOA_GCMS & 6/9/1993 6:57 AM & 10 & ug/L & $U$ & \\
\hline 699-S31-E10C & Vinyl chloride & 8260_VOA_GCMS & 6/9/1993 10:05 AM & 10 & ug/L & $U$ & \\
\hline 699-S31-E10C & Vinyl chloride & 8240_VOA_GCMS & 9/21/1993 8:30 AM & 10 & $u g / L$ & $U$ & \\
\hline 699-S31-E10C & Vinyl chloride & 8240_VOA_GCMS & 9/21/1993 9:54 AM & 10 & ug/L & U & \\
\hline 699-S31-E10C & Vinyl chloride & 8260_VOA_GCMS & 11/30/1993 9:40 AM & 1 & ug/L & & \\
\hline 699-S31-E10C & Vinyl chloride & 8260_VOA_GCMS & 11/30/1993 9:40 AM & 1 & ug/L & & \\
\hline 699-S31-E10C & Vinyl chloride & 8260_VOA_GCMS & 3/21/1994 10:22 AM & 1 & ug/L & $\mathrm{U}$ & \\
\hline 699-S31-E10C & Vinyl chloride & 8260_VOA_GCMS & 3/21/1994 10:22 AM & 1 & ug/L & $U$ & \\
\hline 699-S31-E10C & Vinyl chloride & 8260_VOA_GCMS & 6/6/1994 9:22 AM & 0.5 & ug/L & U & \\
\hline 699-S31-E10C & Vinyl chloride & 8260_VOA_GCMS & 6/6/1994 9:22 AM & 0.5 & ug/L & U & \\
\hline 699-S31-E10C & Vinyl chloride & 8260_VOA_GCMS & 10/11/1994 11:50 AM & 1 & ug/L & U & \\
\hline 699-S31-E10C & Vinyl chloride & 8260_VOA_GCMS & 10/11/1994 2:00 PM & & $\mathrm{ug} / \mathrm{L}$ & $\mathrm{U}$ & \\
\hline
\end{tabular}




\begin{tabular}{|c|c|c|c|c|c|c|c|}
\hline Well Name & Constituent & Method Name & Sample Date/Time & Value & Units & \begin{tabular}{|c|} 
Lab \\
Qualifier \\
\end{tabular} & \begin{tabular}{|l|} 
Review \\
Qualifier
\end{tabular} \\
\hline 699-S31-E10C & Vinyl chloride & 8260_VOA_GCMS & 4/11/1995 11:30 AM & 3 & ug/L & & \\
\hline 699-S31-E10C & Vinyl chloride & 8240_VOA_GCMS & 5/22/1996 12:25 PM & 10 & $\mathrm{ug} / \mathrm{L}$ & $\mathrm{U}$ & \\
\hline 699-S31-E10C & Vinyl chloride & 8260_VOA_GCMS & 5/20/1997 2:35 PM & 1 & $\mathrm{ug} / \mathrm{L}$ & $\mathrm{U}$ & \\
\hline 699-S31-E10C & Vinyl chloride & 8260_VOA_GCMS & 6/19/1998 10:06 AM & 0.68 & $\mathrm{ug} / \mathrm{L}$ & $\mathrm{U}$ & \\
\hline 699-S31-E10C & Vinyl chloride & 8260_VOA_GCMS & 6/14/1999 11:01 AM & 0.1 & $\mathrm{ug} / \mathrm{L}$ & $U$ & \\
\hline 699-S31-E10C & Vinyl chloride & 8260_VOA_GCMS & 10/11/2000 10:31 AM & 0.17 & $\mathrm{ug} / \mathrm{L}$ & $U$ & \\
\hline 699-S31-E10C & Vinyl chloride & 8260_VOA_GCMS & 5/1/2001 10:30 AM & 0.17 & $\mathrm{ug} / \mathrm{L}$ & U & \\
\hline 699-S31-E10C & Vinyl chloride & 8260_VOA_GCMS & $7 / 26 / 2002$ 11:45 AM & 0.32 & $\mathrm{ug} / \mathrm{L}$ & $U$ & \\
\hline 699-S31-E10C & Vinyl chloride & 8260_VOA_GCMS & 7/22/2003 9:21 AM & 0.25 & $\mathrm{ug} / \mathrm{L}$ & $\mathrm{U}$ & \\
\hline 699-S31-E10C & Vinyl chloride & 8260_VOA_GCMS & $7 / 14 / 2004$ 10:50 AM & 0.08 & $\mathrm{ug} / \mathrm{L}$ & $U$ & \\
\hline 699-S31-E10C & Vinyl chloride & 8260_VOA_GCMS & 7/19/2005 11:54 AM & 0.07 & $\mathrm{ug} / \mathrm{L}$ & $U$ & $G$ \\
\hline 699-S31-E10C & Vinyl chloride & 8260_VOA_GCMS & 11/18/2005 11:35 AM & 0.07 & $\mathrm{ug} / \mathrm{L}$ & $\mathrm{U}$ & \\
\hline 699-S31-E10C & Vinyl chloride & 8260_VOA_GCMS & 11/30/2006 9:24 AM & 0.23 & $\mathrm{ug} / \mathrm{L}$ & U & \\
\hline 699-S31-E10D & Vinyl chloride & CLP_VOA_GCMS & 1/30/1990 11:55 AM & 10 & $\mathrm{ug} / \mathrm{L}$ & $\mathrm{U}$ & \\
\hline 699-S31-E10D & Vinyl chloride & CLP_VOA_GCMS & 5/16/1990 12:00 PM & 10 & $\mathrm{ug} / \mathrm{L}$ & $U$ & \\
\hline 699-S31-E10D & Vinyl chloride & CLP_VOA_GCMS & 5/16/1990 12:00 PM & 2 & $u g / L$ & UJ & \\
\hline 699-S31-E10D & Vinyl chloride & CLP_VOA_GCMS & 8/28/1990 12:40 PM & 2 & $\mathrm{ug} / \mathrm{L}$ & $U$ & \\
\hline 699-S31-E10D & Vinyl chloride & CLP_VOA_GCMS & 11/27/1990 2:18 PM & 1 & $\mathrm{ug} / \mathrm{L}$ & $U$ & \\
\hline 699-S31-E10D & Vinyl chloride & CLP_VOA_GCMS & 3/15/1991 2:07 PM & 10 & $\mathrm{ug} / \mathrm{L}$ & U & \\
\hline 699-S31-E10D & Vinyl chloride & CLP_VOA_GCMS & 6/17/1991 10:20 AM & 10 & $\mathrm{ug} / \mathrm{L}$ & $U$ & \\
\hline 699-S31-E10D & Vinyl chloride & CLP_VOA_GCMS & 8/12/1991 11:12 AM & 10 & $\mathrm{ug} / \mathrm{L}$ & $U$ & \\
\hline 699-S31-E10D & Vinyl chloride & CLP_VOA_GCMS & 9/16/1991 11:45 AM & 10 & $\mathrm{ug} / \mathrm{L}$ & $U$ & \\
\hline 699-S31-E10D & Vinyl chloride & CLP_VOA_GCMS & 11/12/1991 10:53 AM & 10 & $\mathrm{ug} / \mathrm{L}$ & U & \\
\hline 699-S31-E10D & Vinyl chloride & 8240_VOA_GCMS & 3/10/1992 1:23 AM & 10 & $\mathrm{ug} / \mathrm{L}$ & $\mathrm{U}$ & \\
\hline 699-S31-E10D & Vinyl chloride & 8240_VOA_GCMS & 3/10/1992 12:56 PM & 1 & ug/L & $\mathrm{U}$ & \\
\hline 699-S31-E10D & Vinyl chloride & 8240_VOA_GCMS & 5/12/1992 12:00 AM & 10 & $\mathrm{ug} / \mathrm{L}$ & $\mathrm{U}$ & \\
\hline 699-S31-E10D & Vinyl chloride & 8260_VOA_GCMS & 5/12/1992 9:28 AM & 1 & $\mathrm{ug} / \mathrm{L}$ & U & \\
\hline 699-S31-E10D & Vinyl chloride & 8260_VOA_GCMS & 9/14/1992 2:43 PM & 1 & $\mathrm{ug} / \mathrm{L}$ & $\mathrm{U}$ & \\
\hline 699-S31-E10D & Vinyl chloride & 8240_VOA_GCMS & 12/7/1992 9:20 AM & 10 & $\mathrm{ug} / \mathrm{L}$ & $U$ & \\
\hline 699-S31-E10D & Vinyl chloride & 8240_VOA_GCMS & 3/15/1993 9:00 AM & 10 & $\mathrm{ug} / \mathrm{L}$ & UJ & \\
\hline 699-S31-E10D & Vinyl chloride & 8260_VOA_GCMS & 6/7/1993 9:22 AM & 10 & ug/L & $U$ & \\
\hline 699-S31-E10D & Vinyl chloride & 8240_VOA_GCMS & 9/21/1993 9:00 AM & 10 & $\mathrm{ug} / \mathrm{L}$ & $U$ & \\
\hline 699-S31-E10D & Vinyl chloride & 8260_VOA_GCMS & 11/30/1993 9:00 AM & 1 & $\mathrm{ug} / \mathrm{L}$ & & \\
\hline 699-S31-E10D & Vinyl chloride & 8260_VOA_GCMS & 3/21/1994 9:20 AM & 1 & $\mathrm{ug} / \mathrm{L}$ & $U$ & \\
\hline 699-S31-E10D & Vinyl chloride & 8260_VOA_GCMS & 6/6/1994 10:50 AM & 0.5 & $\mathrm{ug} / \mathrm{L}$ & $U$ & \\
\hline 699-S31-E10D & Vinyl chloride & 8260_VOA_GCMS & 10/11/1994 10:50 AM & 1 & $u g / L$ & $\mathrm{U}$ & \\
\hline 699-S31-E10D & Vinyl chloride & 8260_VOA_GCMS & 4/11/1995 10:45 AM & 3 & $\mathrm{ug} / \mathrm{L}$ & & \\
\hline 699-S31-E10D & Vinyl chloride & 8240_VOA_GCMS & 5/22/1996 1:04 PM & 10 & $\mathrm{ug} / \mathrm{L}$ & $\mathrm{U}$ & \\
\hline 699-S31-E10D & Vinyl chloride & 8260_VOA_GCMS & 5/20/1997 2:00 PM & 1 & ug/L & $U$ & \\
\hline 699-S31-E10D & Vinyl chloride & 8260_VOA_GCMS & 6/19/1998 9:07 AM & 0.68 & $\mathrm{ug} / \mathrm{L}$ & $\mathrm{U}$ & \\
\hline 699-S31-E10D & Vinyl chloride & 8260_VOA_GCMS & 6/15/1999 10:32 AM & 0.1 & $\mathrm{ug} / \mathrm{L}$ & U & \\
\hline 699-S31-E10D & Vinyl chloride & 8260_VOA_GCMS & 10/11/2000 9:24 AM & 0.17 & $\mathrm{ug} / \mathrm{L}$ & $\mathrm{U}$ & \\
\hline 699-S31-E10D & Vinyl chloride & 8260_VOA_GCMS & 5/1/2001 1:21 PM & 0.17 & ug/L & $\mathrm{U}$ & \\
\hline 699-S31-E10D & Vinyl chloride & 8260_VOA_GCMS & 7/26/2002 10:04 AM & 0.32 & $u g / L$ & U & \\
\hline 699-S31-E10D & Vinyl chloride & 8260_VOA_GCMS & 7/22/2003 8:33 AM & 0.25 & ug/L & $U$ & \\
\hline 699-S31-E10D & Vinyl chloride & 8260_VOA_GCMS & 7/14/2004 9:18 AM & 0.08 & ug/L & $U$ & \\
\hline 699-S31-E10D & Vinyl chloride & 8260_VOA_GCMS & 9/29/2005 8:44 AM & 0.07 & ug/L & $U$ & \\
\hline 699-S31-E10D & Vinyl chloride & 8260_VOA_GCMS & 3/29/2006 11:51 AM & 0.23 & ug/L & $U$ & \\
\hline 699-S31-E11 & Vinyl chloride & CLP_VOA_GCMS & 6/27/1991 1:48 PM & 10 & ug/L & U & \\
\hline 699-S31-E11 & Vinyl chloride & CLP_VOA_GCMS & 8/13/1991 10:03 AM & 10 & ug/L & $\mathrm{U}$ & \\
\hline 699-S31-E11 & Vinyl chloride & CLP_VOA_GCMS & 9/17/1991 8:17 AM & 10 & ug/L & U & \\
\hline \begin{tabular}{|l|}
$699-S 31-E 11$ \\
\end{tabular} & Vinyl chloride & CLP_VOA_GCMS & 11/14/1991 12:00 AM & 10 & $u g / L$ & $\mathrm{U}$ & \\
\hline 699-S31-E11 & Vinyl chloride & 8260_VOA_GCMS & 5/11/1992 12:00 AM & 1 & ug/L & $U$ & \\
\hline 699-S31-E11 & Vinyl chloride & 8260_VOA_GCMS & 5/11/1992 12:00 AM & 1 & ug/L & U & \\
\hline 699-S31-E11 & Vinyl chloride & 8260_VOA_GCMS & 9/16/1992 10:35 AM & 1 & ug/L & U & \\
\hline 699-S31-E11 & Vinyl chloride & 8240_VOA_GCMS & 3/17/1993 10:28 AM & 10 & $\mathrm{ug} / \mathrm{L}$ & U & \\
\hline 699-S31-E11 & Vinyl chloride & 8240_VOA_GCMS & 3/17/1993 10:34 AM & 10 & $\mathrm{ug} / \mathrm{L}$ & $\mathrm{U}$ & \\
\hline
\end{tabular}




\begin{tabular}{|c|c|c|c|c|c|c|c|}
\hline Well Name & Constituent & Method Name & Sample Date/Time & Value & Units & $\begin{array}{c}\text { Lab } \\
\text { Qualifier }\end{array}$ & \begin{tabular}{|l|} 
Review \\
Qualifier
\end{tabular} \\
\hline 699-S31-E11 & Vinyl chloride & 8240_VOA_GCMS & 9/23/1993 10:50 AM & 10 & $\mathrm{ug} / \mathrm{L}$ & U & \\
\hline 699-S31-E11 & Vinyl chloride & 8260_VOA_GCMS & 12/1/1993 10:50 AM & & ug/L & $U$ & \\
\hline 699-S31-E11 & Vinyl chloride & 8260_VOA_GCMS & 4/10/1995 10:00 AM & 3 & $\mathrm{ug} / \mathrm{L}$ & & \\
\hline 699-S31-E11 & Vinyl chloride & 8240_VOA_GCMS & 5/24/1996 10:15 AM & 10 & ug/L & U & \\
\hline 699-S31-E11 & Vinyl chloride & 8260_VOA_GCMS & 5/22/1997 8:09 AM & 1 & $\mathrm{ug} / \mathrm{L}$ & $U$ & \\
\hline 699-S31-E11 & Vinyl chloride & 8260_VOA_GCMS & 6/19/1998 7:41 AM & 0.68 & $\mathrm{ug} / \mathrm{L}$ & $U$ & \\
\hline 699-S31-E11 & Vinyl chloride & 8260_VOA_GCMS & 6/19/1998 7:41 AM & 0.68 & ug/L & U & \\
\hline 699-S31-E11 & Vinyl chloride & 8260_VOA_GCMS & 6/15/1999 9:49 AM & 0.1 & ug/L & $U$ & \\
\hline 699-S31-E11 & Vinyl chloride & 8260_VOA_GCMS & 10/12/2000 12:02 PM & 0.17 & ug/L & U & \\
\hline 699-S31-E11 & Vinyl chloride & 8260_VOA_GCMS & 5/1/2001 9:50 AM & 0.17 & ug/L & U & \\
\hline 699-S31-E11 & Vinyl chloride & 8260_VOA_GCMS & 7/25/2002 11:38 AM & 0.32 & $\mathrm{ug} / \mathrm{L}$ & $\mathrm{U}$ & \\
\hline 699-S31-E11 & Vinyl chloride & 8260_VOA_GCMS & 7/31/2003 11:12 AM & 0.25 & ug/L & $U$ & \\
\hline 699-S31-E11 & Vinyl chloride & 8260_VOA_GCMS & 7/15/2004 12:04 PM & 0.08 & ug/L & U & \\
\hline 699-S31-E11 & Vinyl chloride & 8260_VOA_GCMS & 9/29/2005 10:42 AM & 0.07 & ug/L & $U$ & \\
\hline 699-S31-E11 & Vinyl chloride & 8260_VOA_GCMS & 3/29/2006 10:57 AM & 0.23 & $\mathrm{ug} / \mathrm{L}$ & $U$ & \\
\hline 699-S27-E12A & cis-1,2-Dichloroethylene & 8260_VOA_GCMS & 6/22/1998 1:28 PM & 0.1 & ug/L & U & \\
\hline 699-S27-E12A & cis-1,2-Dichloroethylene & 8260_VOA_GCMS & 6/22/1998 1:28 PM & 0.1 & ug/L & $U$ & \\
\hline 699-S27-E12A & cis-1,2-Dichloroethylene & 8260_VOA_GCMS & 6/14/1999 10:07 AM & 0.15 & ug/L & $U$ & \\
\hline 699-S27-E12A & cis-1,2-Dichloroethylene & 8260_VOA_GCMS & 10/11/2000 10:05 AM & 0.18 & ug/L & U & \\
\hline 699-S27-E12A & cis-1,2-Dichloroethylene & 8260_VOA_GCMS & 4/30/2001 1:16 PM & 0.18 & $\mathrm{ug} / \mathrm{L}$ & $U$ & \\
\hline 699-S27-E12A & cis-1,2-Dichloroethylene & 8260_VOA_GCMS & $7 / 25 / 2002$ 10:36 AM & 0.24 & ug/L & $U$ & \\
\hline 699-S27-E12A & cis-1,2-Dichloroethylene & 8260_VOA_GCMS & 7/21/2003 12:52 PM & 0.06 & ug/L & U & \\
\hline 699-S27-E12A & cis-1,2-Dichloroethylene & 8260_VOA_GCMS & 7/14/2004 11:01 AM & 0.1 & ug/L & $U$ & \\
\hline 699-S27-E12A & cis-1,2-Dichloroethylene & 8260_VOA_GCMS & 9/29/2005 9:55 AM & 0.27 & $\mathrm{ug} / \mathrm{L}$ & $U$ & \\
\hline 699-S27-E12A & cis-1,2-Dichloroethylene & 8260_VOA_GCMS & 11/6/2006 12:12 PM & 0.19 & ug/L & $U$ & \\
\hline 699-S28-E12 & cis-1,2-Dichloroethylene & 502.2_VOA_GC & 7/30/1993 9:30 AM & 0.5 & ug/L & $U$ & \\
\hline 699-S28-E12 & cis-1,2-Dichloroethylene & 502.2_VOA_GC & 5/10/1994 8:30 AM & 0.5 & $\mathrm{ug} / \mathrm{L}$ & $U$ & \\
\hline 699-S28-E12 & cis-1,2-Dichloroethylene & 502.2_VOA_GC & 10/17/1994 8:50 AM & 0.5 & ug/L & U & \\
\hline 699-S28-E12 & cis-1,2-Dichloroethylene & 502.2_VOA_GC & 1/26/1995 8:40 AM & 0.5 & $\mathrm{ug} / \mathrm{L}$ & $U$ & \\
\hline 699-S28-E12 & cis-1,2-Dichloroethylene & 8010_VOA_GC & 1/17/1996 10:50 AM & 0.049 & $\mathrm{ug} / \mathrm{L}$ & $U$ & \\
\hline 699-S28-E12 & cis-1,2-Dichloroethylene & 8260_VOA_GCMS & 6/19/1998 8:25 AM & 0.1 & ug/L & $U$ & \\
\hline 699-S28-E12 & cis-1,2-Dichloroethylene & 8260_VOA_GCMS & 6/30/1998 7:52 AM & 0.1 & $\mathrm{ug} / \mathrm{L}$ & $U$ & \\
\hline 699-S28-E12 & cis-1,2-Dichloroethylene & 8260_VOA_GCMS & 6/14/1999 8:50 AM & 0.15 & $\mathrm{ug} / \mathrm{L}$ & $U$ & \\
\hline 699-S28-E12 & cis-1,2-Dichloroethylene & 8260_VOA_GCMS & 10/11/2000 9:23 AM & 0.18 & $\mathrm{ug} / \mathrm{L}$ & $\mathrm{U}$ & \\
\hline 699-S28-E12 & cis-1,2-Dichloroethylene & 8260_VOA_GCMS & 5/2/2001 11:53 AM & 0.18 & $\mathrm{ug} / \mathrm{L}$ & $U$ & \\
\hline 699-S28-E12 & cis-1,2-Dichloroethylene & 8260_VOA_GCMS & $7 / 25 / 20028: 53 \mathrm{AM}$ & 0.24 & $\mathrm{ug} / \mathrm{L}$ & $U$ & \\
\hline 699-S28-E12 & cis-1,2-Dichloroethylene & 8260_VOA_GCMS & $7 / 25 / 20028: 53 \mathrm{AM}$ & 0.24 & ug/L & $U$ & \\
\hline 699-S28-E12 & cis-1,2-Dichloroethylene & 8260_VOA_GCMS & 9/10/2003 10:21 AM & 0.06 & ug/L & $U$ & \\
\hline 699-S28-E12 & cis-1,2-Dichloroethylene & 8260_VOA_GCMS & 7/13/2004 11:46 AM & 0.1 & $\mathrm{ug} / \mathrm{L}$ & $U$ & \\
\hline 699-S28-E12 & cis-1,2-Dichloroethylene & 8260_VOA_GCMS & 7/14/2005 10:59 AM & 0.27 & $\mathrm{ug} / \mathrm{L}$ & $\mathrm{U}$ & \\
\hline 699-S28-E12 & cis-1,2-Dichloroethylene & 8260_VOA_GCMS & 11/6/2006 12:50 PM & 0.19 & $\mathrm{ug} / \mathrm{L}$ & $U$ & \\
\hline 699-S28-E13A & cis-1,2-Dichloroethylene & 8260_VOA_GCMS & 6/19/1998 1:17 PM & 0.1 & ug/L & $U$ & \\
\hline 699-S28-E13A & cis-1,2-Dichloroethylene & 8260_VOA_GCMS & 6/14/1999 9:26 AM & 0.15 & ug/L & $U$ & \\
\hline 699-S28-E13A & cis-1,2-Dichloroethylene & 8260_VOA_GCMS & 10/11/2000 11:19 AM & 0.18 & ug/L & $U$ & \\
\hline 699-S28-E13A & cis-1,2-Dichloroethylene & 8260_VOA_GCMS & 4/30/2001 12:04 PM & 0.18 & $\mathrm{ug} / \mathrm{L}$ & $U$ & \\
\hline 699-S28-E13A & cis-1,2-Dichloroethylene & 8260_VOA_GCMS & 7/25/2002 10:54 AM & 0.24 & $\mathrm{ug} / \mathrm{L}$ & $U$ & \\
\hline 699-S28-E13A & cis-1,2-Dichloroethylene & 8260_VOA_GCMS & 7/17/2003 11:20 AM & 0.06 & ug/L & $U$ & \\
\hline 699-S28-E13A & cis-1,2-Dichloroethylene & 8260_VOA_GCMS & 7/13/2004 10:57 AM & 0.1 & $\mathrm{ug} / \mathrm{L}$ & $U$ & \\
\hline 699-S28-E13A & cis-1,2-Dichloroethylene & 8260_VOA_GCMS & 9/29/2005 9:08 AM & 0.27 & ug/L & $U$ & \\
\hline 699-S28-E13A & cis-1,2-Dichloroethylene & 8260_VOA_GCMS & 8/31/2006 11:20 AM & 0.19 & $\mathrm{ug} / \mathrm{L}$ & $U$ & \\
\hline 699-S29-E10A & cis-1,2-Dichloroethylene & 8260_VOA_GCMS & 6/22/1998 12:39 PM & 0.1 & $\mathrm{ug} / \mathrm{L}$ & $U$ & \\
\hline 699-S29-E10A & cis-1,2-Dichloroethylene & 8260_VOA_GCMS & 6/14/1999 10:44 AM & 0.15 & ug/L & $U$ & \\
\hline 699-S29-E10A & cis-1,2-Dichloroethylene & 8260_VOA_GCMS & 10/11/2000 8:00 AM & 0.18 & $\mathrm{ug} / \mathrm{L}$ & $U$ & \\
\hline 699-S29-E10A & cis-1,2-Dichloroethylene & 8260_VOA_GCMS & 5/2/2001 9:05 AM & 0.18 & $\mathrm{ug} / \mathrm{L}$ & $U$ & \\
\hline 699-S29-E10A & cis-1,2-Dichloroethylene & 8260_VOA_GCMS & 5/2/2001 9:05 AM & 0.18 & $\mathrm{ug} / \mathrm{L}$ & $U$ & \\
\hline 699-S29-E10A & cis-1,2-Dichloroethylene & 8260_VOA_GCMS & 7/25/2002 11:35 AM & 0.24 & $\mathrm{ug} / \mathrm{L}$ & $U$ & \\
\hline 699-S29-E10A & cis-1,2-Dichloroethylene & 8260_VOA_GCMS & 7/17/2003 1:08 PM & 0.06 & $\mathrm{ug} / \mathrm{L}$ & $U$ & \\
\hline 699-S29-E10A & cis-1,2-Dichloroethylene & 8260_VOA_GCMS & 7/13/2004 12:28 PM & 0.1 & ug/L & $U$ & \\
\hline 699-S29-E10A & cis-1,2-Dichloroethylene & 8260_VOA_GCMS & 9/29/2005 11:23 AM| & 0.27 & ug/L & $u$ & \\
\hline 699-S29-E10A & cis-1,2-Dichloroethylene & 8260_VOA_GCMS & 11/30/2006 11:10 AM & 0.19 & ug/L & $U$ & \\
\hline 699-S29-E11 & cis-1,2-Dichloroethylene & 8260_VOA_GCMS & 9/16/1992 9:35 AM & 0.5 & ug/L & $U$ & \\
\hline
\end{tabular}




\begin{tabular}{|c|c|c|c|c|c|c|c|}
\hline Well Name & Constituent & Method Name & Sample Date/Time & Value & Units & $\begin{array}{c}\text { Lab } \\
\text { Qualifier }\end{array}$ & \begin{tabular}{|l|} 
Review \\
Qualifier
\end{tabular} \\
\hline 699-S29-E11 & cis-1,2-Dichloroethylene & 8260_VOA_GCMS & 12/1/1993 11:40 AM & & ug/L & U & \\
\hline 699-S29-E11 & cis-1,2-Dichloroethylene & 8260_VOA_GCMS & 3/23/1994 9:07 AM & & ug/L & $U$ & \\
\hline 699-S29-E11 & cis-1,2-Dichloroethylene & 8260_VOA_GCMS & 10/11/1994 9:11 AM & & ug/L & $U$ & \\
\hline 699-S29-E11 & cis-1,2-Dichloroethylene & 8260_VOA_GCMS & 10/11/1994 9:45 AM & & ug/L & U & \\
\hline 699-S29-E11 & cis-1,2-Dichloroethylene & 502.2_VOA_GC & 10/18/1994 12:01 PM & 0.5 & $\mathrm{ug} / \mathrm{L}$ & $U$ & \\
\hline 699-S29-E11 & cis-1,2-Dichloroethylene & 8260_VOA_GCMS & 4/10/1995 11:00 AM & 2.8 & $\mathrm{ug} / \mathrm{L}$ & & \\
\hline 699-S29-E11 & cis-1,2-Dichloroethylene & 8010_VOA_GC & 3/4/1996 9:05 AM & 0.049 & ug/L & $U$ & \\
\hline 699-S29-E11 & cis-1,2-Dichloroethylene & 8010_VOA_GC & 1/20/1997 10:54 AM & 0.2 & ug/L & $U$ & \\
\hline 699-S29-E11 & cis-1,2-Dichloroethylene & 8260_VOA_GCMS & 1/19/1998 9:22 AM & 0.1 & $\mathrm{ug} / \mathrm{L}$ & $U$ & \\
\hline 699-S29-E11 & cis-1,2-Dichloroethylene & 8260_VOA_GCMS & 1/20/1999 11:38 AM & 0.13 & ug/L & U & \\
\hline 699-S29-E11 & cis-1,2-Dichloroethylene & 8260_VOA_GCMS & 5/2/2001 12:51 PM & 0.18 & ug/L & $\mathrm{U}$ & \\
\hline 699-S29-E11 & cis-1,2-Dichloroethylene & 8260_VOA_GCMS & 7/25/2002 12:16 PM & 0.24 & $\mathrm{ug} / \mathrm{L}$ & $U$ & \\
\hline 699-S29-E11 & cis-1,2-Dichloroethylene & 8260_VOA_GCMS & 7/25/2002 12:16 PM & 0.24 & ug/L & $U$ & \\
\hline 699-S29-E11 & cis-1,2-Dichloroethylene & 8260_VOA_GCMS & 7/17/2003 12:24 PM & 0.06 & ug/L & $U$ & \\
\hline 699-S29-E11 & cis-1,2-Dichloroethylene & 8260_VOA_GCMS & 7/13/2004 11:45 AM & 0.1 & ug/L & $U$ & \\
\hline 699-S29-E11 & cis-1,2-Dichloroethylene & 8260_VOA_GCMS & 7/14/2005 11:54 AM & 0.27 & $\mathrm{ug} / \mathrm{L}$ & U & \\
\hline 699-S29-E11 & cis-1,2-Dichloroethylene & 8260_VOA_GCMS & 12/27/2006 1:20 PM| & 0.19 & ug/L & $U$ & \\
\hline 699-S29-E12 & cis-1,2-Dichloroethylene & 8260_VOA_GCMS & 5/14/1992 9:19 AM & 0.5 & ug/L & $U$ & \\
\hline 699-S29-E12 & cis-1,2-Dichloroethylene & 8260_VOA_GCMS & 9/15/1992 5:40 AM & 0.5 & ug/L & U & \\
\hline 699-S29-E12 & cis-1,2-Dichloroethylene & 502.2_VOA_GC & 8/24/1993 12:46 PM & 0.5 & ug/L & $U$ & \\
\hline 699-S29-E12 & cis-1,2-Dichloroethylene & 8260_VOA_GCMS & 12/1/1993 9:30 AM & & ug/L & $U$ & \\
\hline 699-S29-E12 & cis-1,2-Dichloroethylene & 8260_VOA_GCMS & 3/22/1994 12:45 PM & & ug/L & U & \\
\hline 699-S29-E12 & cis-1,2-Dichloroethylene & 502.2_VOA_GC & 5/11/1994 8:30 AM & 0.5 & ug/L & $U$ & \\
\hline 699-S29-E12 & cis-1,2-Dichloroethylene & 8260_VOA_GCMS & 6/8/1994 10:40 AM & 0.6 & ug/L & $U$ & \\
\hline 699-S29-E12 & cis-1,2-Dichloroethylene & 8260_VOA_GCMS & 10/12/1994 12:15 PM & 1 & ug/L & $U$ & \\
\hline 699-S29-E12 & cis-1,2-Dichloroethylene & 502.2_VOA_GC & 1/18/1995 8:00 AM & 0.5 & ug/L & $U$ & \\
\hline 699-S29-E12 & cis-1,2-Dichloroethylene & 8260_VOA_GCMS & 4/11/1995 12:00 PM & 2.8 & $\mathrm{ug} / \mathrm{L}$ & $U$ & \\
\hline 699-S29-E12 & cis-1,2-Dichloroethylene & 8260_VOA_GCMS & 4/11/1995 1:15 PM & 2.8 & ug/L & U & \\
\hline 699-S29-E12 & cis-1,2-Dichloroethylene & 8010_VOA_GC & 1/15/1996 9:10 AM & 0.049 & $\mathrm{ug} / \mathrm{L}$ & $U$ & \\
\hline 699-S29-E12 & cis-1,2-Dichloroethylene & 8010_VOA_GC & 1/16/1997 9:20 AM & 0.2 & $\mathrm{ug} / \mathrm{L}$ & $U$ & \\
\hline 699-S29-E12 & cis-1,2-Dichloroethylene & 8010_VOA_GC & 1/16/1997 9:20 AM & 0.2 & ug/L & $U$ & \\
\hline 699-S29-E12 & cis-1,2-Dichloroethylene & 8260_VOA_GCMS & 1/12/1998 12:23 PM & 0.1 & $\mathrm{ug} / \mathrm{L}$ & $U$ & \\
\hline 699-S29-E12 & cis-1,2-Dichloroethylene & 8260_VOA_GCMS & 1/20/1999 9:17 AM & 0.13 & $\mathrm{ug} / \mathrm{L}$ & $U$ & \\
\hline 699-S29-E12 & cis-1,2-Dichloroethylene & 8260_VOA_GCMS & $7 / 25 / 2002$ 9:45 AM & 0.24 & $\mathrm{ug} / \mathrm{L}$ & $\mathrm{U}$ & \\
\hline 699-S29-E12 & cis-1,2-Dichloroethylene & 8260_VOA_GCMS & 7/21/2003 12:10 PM| & 0.06 & ug/L & $U$ & \\
\hline 699-S29-E12 & cis-1,2-Dichloroethylene & 8260_VOA_GCMS & 7/13/2004 10:01 AM & 0.1 & $\mathrm{ug} / \mathrm{L}$ & $U$ & \\
\hline 699-S29-E12 & cis-1,2-Dichloroethylene & 8260_VOA_GCMS & 11/18/2005 10:51 AM & 0.27 & ug/L & $U$ & \\
\hline 699-S29-E12 & cis-1,2-Dichloroethylene & 8260_VOA_GCMS & 11/6/2006 1:32 PM & 0.19 & $\mathrm{ug} / \mathrm{L}$ & $U$ & \\
\hline 699-S29-E13A & cis-1,2-Dichloroethylene & 8260_VOA_GCMS & 6/24/1998 8:37 AM & 0.1 & $\mathrm{ug} / \mathrm{L}$ & $U$ & \\
\hline 699-S29-E13A & cis-1,2-Dichloroethylene & 8260_VOA_GCMS & 6/15/1999 8:27 AM & 0.15 & $\mathrm{ug} / \mathrm{L}$ & $\mathrm{U}$ & \\
\hline 699-S29-E13A & cis-1,2-Dichloroethylene & 8260_VOA_GCMS & 6/15/1999 8:27 AM & 0.15 & $\mathrm{ug} / \mathrm{L}$ & $U$ & \\
\hline 699-S29-E13A & cis-1,2-Dichloroethylene & 8260_VOA_GCMS & 10/11/2000 12:38 PM & 0.18 & $\mathrm{ug} / \mathrm{L}$ & $U$ & \\
\hline 699-S29-E13A & cis-1,2-Dichloroethylene & 8260_VOA_GCMS & 10/11/2000 12:38 PM & 0.18 & ug/L & $U$ & \\
\hline 699-S29-E13A & cis-1,2-Dichloroethylene & 8260_VOA_GCMS & 5/2/2001 10:46 AM & 0.18 & $\mathrm{ug} / \mathrm{L}$ & $U$ & \\
\hline 699-S29-E13A & cis-1,2-Dichloroethylene & 8260_VOA_GCMS & 7/25/2002 10:17 AM & 0.24 & $\mathrm{ug} / \mathrm{L}$ & $U$ & \\
\hline 699-S29-E13A & cis-1,2-Dichloroethylene & 8260_VOA_GCMS & 7/22/2003 12:34 PM & 0.06 & ug/L & $U$ & \\
\hline 699-S29-E13A & cis-1,2-Dichloroethylene & 8260_VOA_GCMS & 7/14/2004 11:47 AM| & 0.1 & ug/L & $u$ & \\
\hline 699-S29-E13A & cis-1,2-Dichloroethylene & 8260_VOA_GCMS & 9/29/2005 12:40 PM & 0.27 & ug/L & $U$ & \\
\hline 699-S29-E13A & cis-1,2-Dichloroethylene & 8260_VOA_GCMS & 11/6/2006 11:18 AM & 0.19 & ug/L & $U$ & \\
\hline 699-S30-E10A & cis-1,2-Dichloroethylene & 8260_VOA_GCMS & 5/13/1992 8:57 AM & 0.5 & $\mathrm{ug} / \mathrm{L}$ & $U$ & \\
\hline 699-S30-E10A & cis-1,2-Dichloroethylene & 8260_VOA_GCMS & 9/14/1992 9:00 AM & 0.5 & $\mathrm{ug} / \mathrm{L}$ & $U$ & \\
\hline 699-S30-E10A & cis-1,2-Dichloroethylene & 502.2_VOA_GC & 7/30/1993 8:45 AM & 0.5 & $\mathrm{ug} / \mathrm{L}$ & $U$ & \\
\hline 699-S30-E10A & cis-1,2-Dichloroethylene & 8260_VOA_GCMS & 12/2/1993 9:00 AM & 1 & $\mathrm{ug} / \mathrm{L}$ & $U$ & \\
\hline 699-S30-E10A & cis-1,2-Dichloroethylene & 8260_VOA_GCMS & 3/21/1994 12:25 PM & & ug/L & $U$ & \\
\hline 699-S30-E10A & cis-1,2-Dichloroethylene & 8260_VOA_GCMS & 6/6/1994 12:00 PM & 0.6 & ug/L & UJ & \\
\hline 699-S30-E10A & cis-1,2-Dichloroethylene & 502.2_VOA_GC & 7/11/1994 8:45 AM & 0.5 & ug/L & $U$ & \\
\hline 699-S30-E10A & cis-1,2-Dichloroethylene & 8260_VOA_GCMS & 10/11/1994 1:15 PM & & $\mathrm{ug} / \mathrm{L}$ & $U$ & \\
\hline 699-S30-E10A & cis-1,2-Dichloroethylene & 502.2_VOA_GC & 1/16/1995 8:50 AM & 0.5 & ug/L & $U$ & \\
\hline 699-S30-E10A & cis-1,2-Dichloroethylene & 8260_VOA_GCMS & 4/10/1995 11:43 AM| & 2.8 & ug/L & & \\
\hline 699-S30-E10A & cis-1,2-Dichloroethylene & 8010_VOA_GC & 1/12/1996 1:00 PM & 0.049 & $u g / L$ & $U$ & \\
\hline 699-S30-E10A & cis-1,2-Dichloroethylene & 8240_VOA_GCMS & 5/22/1996 9:06 AM & & ug/L & $U$ & \\
\hline
\end{tabular}




\begin{tabular}{|c|c|c|c|c|c|c|c|}
\hline Well Name & Constituent & Method Name & Sample Date/Time & Value & Units & $\begin{array}{c}\text { Lab } \\
\text { Qualifier }\end{array}$ & $\begin{array}{l}\text { Review } \\
\text { Qualifier }\end{array}$ \\
\hline 699-S30-E10A & cis-1,2-Dichloroethylene & 8260_VOA_GCMS & 6/22/1998 11:18 AM & 0.1 & ug/L & U & \\
\hline 699-S30-E10A & cis-1,2-Dichloroethylene & 8260_VOA_GCMS & 6/22/1998 11:18 AM & 0.1 & ug/L & $U$ & \\
\hline 699-S30-E10A & cis-1,2-Dichloroethylene & 8260_VOA_GCMS & 6/14/1999 12:27 PM & 0.15 & ug/L & $U$ & \\
\hline 699-S30-E10A & cis-1,2-Dichloroethylene & 8260_VOA_GCMS & 10/11/2000 12:09 PM & 0.18 & $\mathrm{ug} / \mathrm{L}$ & $U$ & \\
\hline 699-S30-E10A & cis-1,2-Dichloroethylene & 8260_VOA_GCMS & 5/1/2001 11:45 AM & 0.18 & ug/L & $U$ & \\
\hline 699-S30-E10A & cis-1,2-Dichloroethylene & 8260_VOA_GCMS & 7/31/2002 10:49 AM & 0.24 & ug/L & $U$ & \\
\hline 699-S30-E10A & cis-1,2-Dichloroethylene & 8260_VOA_GCMS & 7/22/2003 9:55 AM & 0.06 & ug/L & $U$ & \\
\hline 699-S30-E10A & cis-1,2-Dichloroethylene & 8260_VOA_GCMS & $7 / 15 / 2004$ 11:12 AM & 0.1 & ug/L & $U$ & \\
\hline 699-S30-E10A & cis-1,2-Dichloroethylene & 8260 VOA GCMS & 7/14/2005 11:32 AM & 0.27 & ug/L & $U$ & \\
\hline 699-S30-E10A & cis-1,2-Dichloroethylene & 8260_VOA_GCMS & 11/6/2006 12:11 PM & 0.19 & ug/L & U & \\
\hline 699-S30-E10B & cis-1,2-Dichloroethylene & 8260_VOA_GCMS & 5/13/1992 9:50 AM & 0.5 & ug/L & $U$ & \\
\hline 699-S30-E10B & cis-1,2-Dichloroethylene & 8260_VOA_GCMS & 9/14/1992 10:00 AM & 0.5 & ug/L & $u$ & \\
\hline 699-S30-E10B & cis-1,2-Dichloroethylene & 502.2_VOA_GC & 7/30/1993 8:30 AM & 0.5 & $\mathrm{ug} / \mathrm{L}$ & $U$ & \\
\hline 699-S30-E10B & cis-1,2-Dichloroethylene & 8260_VOA_GCMS & 12/2/1993 9:40 AM & 1 & ug/L & $U$ & \\
\hline 699-S30-E10B & cis-1,2-Dichloroethylene & 8260 VOA GCMS & 3/21/1994 11:15 AM & 1 & ug/L & U & \\
\hline 699-S30-E10B & cis-1,2-Dichloroethylene & 8260_VOA_GCMS & 6/6/1994 1:25 AM & 0.6 & ug/L & U & \\
\hline 699-S30-E10B & cis-1,2-Dichloroethylene & 502.2_VOA_GC & 7/8/1994 9:45 AM & 0.5 & ug/L & $U$ & \\
\hline 699-S30-E10B & cis-1,2-Dichloroethylene & 8260_VOA_GCMS & 10/11/1994 12:40 PM & 1 & ug/L & $U$ & \\
\hline 699-S30-E10B & cis-1,2-Dichloroethylene & 502.2_VOA_GC & 1/16/1995 8:15 AM & 0.5 & $\mathrm{ug} / \mathrm{L}$ & $U$ & \\
\hline 699-S30-E10B & cis-1,2-Dichloroethylene & 8260_VOA_GCMS & 4/10/1995 12:30 PM & 2.8 & ug/L & & \\
\hline 699-S30-E10B & cis-1,2-Dichloroethylene & 8240 VOA GCMS & 5/22/1996 10:25 AM & 5 & ug/L & U & \\
\hline 699-S30-E10B & cis-1,2-Dichloroethylene & 8010_VOA_GC & 1/20/1997 11:26 AM & 0.2 & ug/L & $\mathrm{U}$ & \\
\hline 699-S30-E10B & cis-1,2-Dichloroethylene & 8260_VOA_GCMS & 1/20/1998 9:40 AM & 0.1 & ug/L & $U$ & \\
\hline 699-S30-E10B & cis-1,2-Dichloroethylene & 8260_VOA_GCMS & 1/20/1998 9:40 AM & 0.1 & ug/L & $U$ & \\
\hline 699-S30-E10B & cis-1,2-Dichloroethylene & 8260_VOA_GCMS & 1/20/1999 12:21 PM & 0.13 & $\mathrm{ug} / \mathrm{L}$ & $U$ & \\
\hline 699-S30-E10B & cis-1,2-Dichloroethylene & 8260_VOA_GCMS & 5/2/2001 10:05 AM & 0.18 & $\mathrm{ug} / \mathrm{L}$ & $U$ & \\
\hline 699-S30-E10B & cis-1,2-Dichloroethylene & 8260 VOA GCMS & 7/31/2002 10:13 AM & 0.24 & ug/L & U & \\
\hline 699-S30-E10B & cis-1,2-Dichloroethylene & 8260_VOA_GCMS & 7/21/2003 12:15 PM & 0.06 & ug/L & $U$ & \\
\hline 699-S30-E10B & cis-1,2-Dichloroethylene & 8260_VOA_GCMS & $7 / 15 / 2004$ 10:35 AM & 0.1 & ug/L & $U$ & \\
\hline 699-S30-E10B & cis-1,2-Dichloroethylene & 8260_VOA_GCMS & $7 / 25 / 200511: 00 \mathrm{AM}$ & 0.27 & $\mathrm{ug} / \mathrm{L}$ & U & \\
\hline 699-S30-E10B & cis-1,2-Dichloroethylene & 8260_VOA_GCMS & 11/6/2006 12:53 PM & 0.19 & $\mathrm{ug} / \mathrm{L}$ & $U$ & \\
\hline 699-S30-E11A & cis-1,2-Dichloroethylene & 8260_VOA_GCMS & 6/19/1998 12:40 PM & 0.1 & $\mathrm{ug} / \mathrm{L}$ & $U$ & \\
\hline 699-S30-E11A & cis-1,2-Dichloroethylene & 8260 VOA GCMS & 6/14/1999 11:20 AM & 0.15 & ug/L & $U$ & \\
\hline 699-S30-E11A & cis-1,2-Dichloroethylene & 8260_VOA_GCMS & 10/11/2000 1:08 PM & 0.18 & ug/L & $\mathrm{U}$ & \\
\hline 699-S30-E11A & cis-1,2-Dichloroethylene & 8260_VOA_GCMS & 5/1/2001 10:43 AM & 0.18 & ug/L & $U$ & \\
\hline 699-S30-E11A & cis-1,2-Dichloroethylene & 8260_VOA_GCMS & $7 / 25 / 2002$ 12:03 PM & 0.24 & $\mathrm{ug} / \mathrm{L}$ & U & \\
\hline 699-S30-E11A & cis-1,2-Dichloroethylene & 8260_VOA_GCMS & 9/10/2003 11:31 AM & 0.06 & $\mathrm{ug} / \mathrm{L}$ & $U$ & \\
\hline 699-S30-E11A & cis-1,2-Dichloroethylene & 8260_VOA_GCMS & $7 / 14 / 200411: 55 \mathrm{AM}$ & 0.1 & $\mathrm{ug} / \mathrm{L}$ & $U$ & \\
\hline 699-S30-E11A & cis-1,2-Dichloroethylene & 8260_VOA_GCMS & 9/29/2005 11:50 AM & 0.27 & ug/L & $U$ & \\
\hline 699-S30-E11A & cis-1,2-Dichloroethylene & 8260_VOA_GCMS & 11/6/2006 2:22 PM & 0.19 & ug/L & $U$ & \\
\hline 699-S31-E10A & cis-1,2-Dichloroethylene & 8240_VOA_GCMS & 3/10/1992 9:18 AM & 0.5 & ug/L & $U$ & \\
\hline 699-S31-E10A & cis-1,2-Dichloroethylene & 8260_VOA_GCMS & 5/11/1992 12:03 PM & 0.5 & $\mathrm{ug} / \mathrm{L}$ & U & \\
\hline 699-S31-E10A & cis-1,2-Dichloroethylene & 8260_VOA_GCMS & 5/11/1992 12:03 PM & 0.5 & $\mathrm{ug} / \mathrm{L}$ & $U$ & \\
\hline 699-S31-E10A & cis-1,2-Dichloroethylene & 8260_VOA_GCMS & 9/14/1992 1:00 PM & 0.5 & ug/L & $U$ & \\
\hline 699-S31-E10A & cis-1,2-Dichloroethylene & 8260_VOA_GCMS & 9/14/1992 1:00 PM & 0.5 & ug/L & U & \\
\hline 699-S31-E10A & cis-1,2-Dichloroethylene & 502.2_VOA_GC & 8/3/1993 9:10 AM & 0.5 & ug/L & $U$ & \\
\hline 699-S31-E10A & cis-1,2-Dichloroethylene & 8260_VOA_GCMS & 11/30/1993 10:40 AM & 5 & ug/L & $U$ & \\
\hline 699-S31-E10A & cis-1,2-Dichloroethylene & 8260_VOA_GCMS & 11/30/1993 10:40 AM & 1 & $\mathrm{ug} / \mathrm{L}$ & & \\
\hline 699-S31-E10A & cis-1,2-Dichloroethylene & 8260_VOA_GCMS & 3/22/1994 9:50 AM & 0.6 & $\mathrm{ug} / \mathrm{L}$ & $U$ & \\
\hline 699-S31-E10A & cis-1,2-Dichloroethylene & 8260_VOA_GCMS & 3/22/1994 9:50 AM & & $\mathrm{ug} / \mathrm{L}$ & $U$ & \\
\hline 699-S31-E10A & cis-1,2-Dichloroethylene & 8260_VOA_GCMS & 6/7/1994 9:46 AM & 0.6 & ug/L & $U$ & \\
\hline 699-S31-E10A & cis-1,2-Dichloroethylene & 502.2_VOA_GC & $7 / 26 / 19948: 45 \mathrm{AM}$ & 0.5 & ug/L & $\mathrm{U}$ & \\
\hline 699-S31-E10A & cis-1,2-Dichloroethylene & 8260_VOA_GCMS & 10/12/1994 10:15 AM & & ug/L & U & \\
\hline 699-S31-E10A & cis-1,2-Dichloroethylene & 8260_VOA_GCMS & 4/12/1995 9:30 AM & & ug/L & & \\
\hline 699-S31-E10A & cis-1,2-Dichloroethylene & 8260_VOA_GCMS & 4/12/1995 9:30 AM & 2.8 & ug/L & & \\
\hline 699-S31-E10A & cis-1,2-Dichloroethylene & 8010_VOA_GC & 11/17/1995 12:00 PM & 0.049 & $\mathrm{ug} / \mathrm{L}$ & $U$ & \\
\hline 699-S31-E10A & cis-1,2-Dichloroethylene & 8260_VOA_GCMS & 6/22/1998 10:37 AM & 0.1 & $\mathrm{ug} / \mathrm{L}$ & $U$ & \\
\hline 699-S31-E10A & cis-1,2-Dichloroethylene & 8260_VOA_GCMS & 6/22/1998 10:37 AM & 0.1 & ug/L & $U$ & \\
\hline 699-S31-E10A & cis-1,2-Dichloroethylene & 8260_VOA_GCMS & 6/14/1999 11:48 AM & 0.15 & $\mathrm{ug} / \mathrm{L}$ & $U$ & \\
\hline 699-S31-E10A & cis-1,2-Dichloroethylene & 8260_VOA_GCMS & 10/11/2000 11:21 AM & 0.18 & ug/L & U & \\
\hline
\end{tabular}




\begin{tabular}{|c|c|c|c|c|c|c|c|}
\hline Well Name & Constituent & Method Name & Sample Date/Time & Value & Units & $\begin{array}{c}\text { Lab } \\
\text { Qualifier }\end{array}$ & $\begin{array}{l}\text { Review } \\
\text { Qualifier }\end{array}$ \\
\hline 699-S31-E10A & cis-1,2-Dichloroethylene & 8260_VOA_GCMS & 5/1/2001 11:13 AM & 0.18 & ug/L & $U$ & \\
\hline 699-S31-E10A & cis-1,2-Dichloroethylene & 8260_VOA_GCMS & $7 / 26 / 2002$ 12:24 PM & 0.24 & ug/L & $\mathrm{U}$ & \\
\hline 699-S31-E10A & cis-1,2-Dichloroethylene & 8260_VOA_GCMS & 7/22/2003 10:16 AM & 0.06 & ug/L & $\mathrm{U}$ & \\
\hline 699-S31-E10A & cis-1,2-Dichloroethylene & 8260_VOA_GCMS & 7/14/2004 12:32 PM & 0.1 & ug/L & $\mathrm{U}$ & \\
\hline 699-S31-E10A & cis-1,2-Dichloroethylene & 8260_VOA_GCMS & 9/29/2005 9:21 AM & 0.27 & ug/L & $\mathrm{U}$ & \\
\hline 699-S31-E10A & cis-1,2-Dichloroethylene & 8260_VOA_GCMS & 3/29/2006 12:28 PM & 0.19 & ug/L & $\mathrm{U}$ & \\
\hline 699-S31-E10C & cis-1,2-Dichloroethylene & 8240_VOA_GCMS & 3/10/1992 11:36 AM & & ug/L & $\mathrm{U}$ & \\
\hline 699-S31-E10C & cis-1,2-Dichloroethylene & 8240_VOA_GCMS & 3/10/1992 11:49 AM & 0.5 & ug/L & $\mathrm{U}$ & \\
\hline 699-S31-E10C & cis-1,2-Dichloroethylene & 8260 VOA GCMS & 5/12/1992 10:27 AM & 0.5 & ug/L & $\bar{U}$ & \\
\hline 699-S31-E10C & cis-1,2-Dichloroethylene & 8260_VOA_GCMS & 5/12/1992 10:27 AM & 0.5 & ug/L & $\mathrm{U}$ & \\
\hline 699-S31-E10C & cis-1,2-Dichloroethylene & 8260_VOA_GCMS & 9/14/1992 10:55 AM & 0.5 & ug/L & $\mathrm{U}$ & \\
\hline 699-S31-E10C & cis-1,2-Dichloroethylene & 8260_VOA_GCMS & 9/14/1992 10:55 AM & 0.5 & ug/L & $\mathrm{U}$ & \\
\hline 699-S31-E10C & cis-1,2-Dichloroethylene & 502.2_VOA_GC & 8/3/1993 8:40 AM & 0.5 & ug/L & $\mathrm{U}$ & \\
\hline 699-S31-E10C & cis-1,2-Dichloroethylene & 8260_VOA_GCMS & 11/30/1993 9:40 AM & 1 & ug/L & & \\
\hline 699-S31-E10C & cis-1,2-Dichloroethylene & 8260 VOA GCMS & 11/30/1993 9:40 AM & 1 & ug/L & & \\
\hline 699-S31-E10C & cis-1,2-Dichloroethylene & 8260_VOA_GCMS & 3/21/1994 10:22 AM & 1 & ug/L & $\mathrm{U}$ & \\
\hline 699-S31-E10C & cis-1,2-Dichloroethylene & 8260_VOA_GCMS & 3/21/1994 10:22 AM & 1 & ug/L & $\mathrm{U}$ & \\
\hline 699-S31-E10C & cis-1,2-Dichloroethylene & 8260_VOA_GCMS & 6/6/1994 9:22 AM & 0.6 & ug/L & $\mathrm{U}$ & \\
\hline 699-S31-E10C & cis-1,2-Dichloroethylene & 8260_VOA_GCMS & 6/6/1994 9:22 AM & 0.6 & ug/L & $\mathrm{U}$ & \\
\hline 699-S31-E10C & cis-1,2-Dichloroethylene & 502.2_VOA_GC & 7/8/1994 8:30 AM & 0.5 & ug/L & $\mathrm{U}$ & \\
\hline 699-S31-E10C & cis-1,2-Dichloroethylene & 8260 VOA GCMS & 10/11/1994 11:50 AM & 1 & ug/L & $\mathrm{U}$ & \\
\hline 699-S31-E10C & cis-1,2-Dichloroethylene & 8260_VOA_GCMS & 10/11/1994 2:00 PM & 1 & ug/L & $\mathrm{U}$ & \\
\hline 699-S31-E10C & cis-1,2-Dichloroethylene & 502.2_VOA_GC & 1/23/1995 8:16 AM & 0.5 & ug/L & $\mathrm{U}$ & \\
\hline 699-S31-E10C & cis-1,2-Dichloroethylene & 8260_VOA_GCMS & 4/11/1995 11:30 AM & 2.8 & ug/L & & \\
\hline 699-S31-E10C & cis-1,2-Dichloroethylene & 8260_VOA_GCMS & 6/19/1998 10:06 AM & 0.1 & ug/L & $\mathrm{U}$ & \\
\hline 699-S31-E10C & cis-1,2-Dichloroethylene & 8260_VOA_GCMS & 6/14/1999 11:01 AM & 0.15 & ug/L & $\mathrm{U}$ & \\
\hline 699-S31-E10C & cis-1,2-Dichloroethylene & 8260 VOA GCMS & $10 / 11 / 200010: 31 \mathrm{AM}$ & 0.18 & ug/L & $\mathrm{U}$ & \\
\hline 699-S31-E10C & cis-1,2-Dichloroethylene & 8260_VOA_GCMS & 5/1/2001 10:30 AM & 0.18 & ug/L & $\mathrm{U}$ & \\
\hline 699-S31-E10C & cis-1,2-Dichloroethylene & 8260_VOA_GCMS & 7/26/2002 11:45 AM & 0.24 & $\mathrm{ug} / \mathrm{L}$ & $\mathrm{U}$ & \\
\hline 699-S31-E10C & cis-1,2-Dichloroethylene & 8260_VOA_GCMS & $7 / 22 / 2003$ 9:21 AM & 0.06 & $\mathrm{ug} / \mathrm{L}$ & $\mathrm{U}$ & \\
\hline 699-S31-E10C & cis-1,2-Dichloroethylene & 8260_VOA_GCMS & 7/14/2004 10:50 AM & 0.1 & ug/L & $\mathrm{U}$ & \\
\hline 699-S31-E10C & cis-1,2-Dichloroethylene & 8260_VOA_GCMS & 7/19/2005 11:54 AM & 0.27 & $\mathrm{ug} / \mathrm{L}$ & $\mathrm{U}$ & G \\
\hline 699-S31-E10C & cis-1,2-Dichloroethylene & 8260_VOA_GCMS & 11/18/2005 11:35 AM & 0.27 & ug/L & $\mathrm{U}$ & \\
\hline 699-S31-E10C & cis-1,2-Dichloroethylene & 8260_VOA_GCMS & 11/30/2006 9:24 AM & 0.19 & $\mathrm{ug} / \mathrm{L}$ & $\mathrm{U}$ & \\
\hline 699-S31-E10D & cis-1,2-Dichloroethylene & 8240_VOA_GCMS & 3/10/1992 12:56 PM & 0.5 & ug/L & $\mathrm{U}$ & \\
\hline 699-S31-E10D & cis-1,2-Dichloroethylene & 8260_VOA_GCMS & 5/12/1992 9:28 AM & 0.5 & $\mathrm{ug} / \mathrm{L}$ & $\mathrm{U}$ & \\
\hline 699-S31-E10D & cis-1,2-Dichloroethylene & 8260_VOA_GCMS & 9/14/1992 2:43 PM & 0.5 & ug/L & $\mathrm{U}$ & \\
\hline 699-S31-E10D & cis-1,2-Dichloroethylene & 502.2_VOA_GC & 8/3/1993 9:40 AM & 0.5 & $\mathrm{ug} / \mathrm{L}$ & $\mathrm{U}$ & \\
\hline 699-S31-E10D & cis-1,2-Dichloroethylene & 8260_VOA_GCMS & 11/30/1993 9:00 AM & 1 & ug/L & & \\
\hline 699-S31-E10D & cis-1,2-Dichloroethylene & 8260_VOA_GCMS & 3/21/1994 9:20 AM & 1 & $u g / L$ & $\mathrm{U}$ & \\
\hline 699-S31-E10D & cis-1,2-Dichloroethylene & 8260_VOA_GCMS & 6/6/1994 10:50 AM & 0.6 & $\mathrm{ug} / \mathrm{L}$ & $\mathrm{U}$ & \\
\hline 699-S31-E10D & cis-1,2-Dichloroethylene & 502.2_VOA_GC & 7/8/1994 8:00 AM & 0.5 & $\mathrm{ug} / \mathrm{L}$ & $\mathrm{U}$ & \\
\hline 699-S31-E10D & cis-1,2-Dichloroethylene & 8260_VOA_GCMS & 10/11/1994 10:50 AM & & ug/L & $\mathrm{U}$ & \\
\hline 699-S31-E10D & cis-1,2-Dichloroethylene & 502.2_VOA_GC & 1/23/1995 8:40 AM & 0.5 & $\mathrm{ug} / \mathrm{L}$ & $\mathrm{U}$ & \\
\hline 699-S31-E10D & cis-1,2-Dichloroethylene & 8260_VOA_GCMS & 4/11/1995 10:45 AM & 2.8 & ug/L & & \\
\hline 699-S31-E10D & cis-1,2-Dichloroethylene & 8260_VOA_GCMS & 6/19/1998 9:07 AM & 0.1 & $u g / L$ & $\mathrm{U}$ & \\
\hline 699-S31-E10D & cis-1,2-Dichloroethylene & 8260_VOA_GCMS & 6/15/1999 10:32 AM & 0.15 & $\mathrm{ug} / \mathrm{L}$ & $\mathrm{U}$ & \\
\hline 699-S31-E10D & cis-1,2-Dichloroethylene & 8260_VOA_GCMS & 10/11/2000 9:24 AM & 0.18 & $\mathrm{ug} / \mathrm{L}$ & $\mathrm{U}$ & \\
\hline 699-S31-E10D & cis-1,2-Dichloroethylene & 8260_VOA_GCMS & 5/1/2001 1:21 PM & 0.18 & ug/L & $\mathrm{U}$ & \\
\hline 699-S31-E10D & cis-1,2-Dichloroethylene & 8260_VOA_GCMS & 7/26/2002 10:04 AM & 0.24 & $\mathrm{ug} / \mathrm{L}$ & $\mathrm{U}$ & \\
\hline 699-S31-E10D & cis-1,2-Dichloroethylene & 8260_VOA_GCMS & $7 / 22 / 20038: 33 \mathrm{AM}$ & 0.06 & $\mathrm{ug} / \mathrm{L}$ & $\mathrm{U}$ & \\
\hline 699-S31-E10D & cis-1,2-Dichloroethylene & 8260_VOA_GCMS & 7/14/2004 9:18 AM & 0.1 & $u g / L$ & $\mathrm{U}$ & \\
\hline 699-S31-E10D & cis-1,2-Dichloroethylene & 8260_VOA_GCMS & 9/29/2005 8:44 AM & 0.27 & $\mathrm{ug} / \mathrm{L}$ & $\mathrm{U}$ & \\
\hline 699-S31-E10D & cis-1,2-Dichloroethylene & 8260_VOA_GCMS & 3/29/2006 11:51 AM & 0.19 & $\mathrm{ug} / \mathrm{L}$ & $\mathrm{U}$ & \\
\hline 699-S31-E11 & cis-1,2-Dichloroethylene & 8260_VOA_GCMS & 5/11/1992 12:00 AM & 0.5 & ug/L & $\mathrm{U}$ & \\
\hline 699-S31-E11 & cis-1,2-Dichloroethylene & 8260_VOA_GCMS & 5/11/1992 12:00 AM & 0.5 & $\mathrm{ug} / \mathrm{L}$ & $\mathrm{U}$ & \\
\hline 699-S31-E11 & cis-1,2-Dichloroethylene & 8260_VOA_GCMS & 9/16/1992 10:35 AM & 0.5 & $\mathrm{ug} / \mathrm{L}$ & $\mathrm{U}$ & \\
\hline 699-S31-E11 & cis-1,2-Dichloroethylene & 8260_VOA_GCMS & 12/1/1993 10:50 AM & 1 & $u g / L$ & $\mathrm{U}$ & \\
\hline 699-S31-E11 & cis-1,2-Dichloroethylene & 502.2_VOA_GC & 10/17/1994 8:15 AM & 0.5 & ug/L & $\mathrm{U}$ & \\
\hline 699-S31-E11 & cis-1,2-Dichloroethylene & 8260_VOA_GCMS & 4/10/1995 10:00 AM & 2.8 & $\mathrm{ug} / \mathrm{L}$ & & \\
\hline
\end{tabular}




\begin{tabular}{|c|c|c|c|c|c|c|c|}
\hline Well Name & Constituent & Method Name & Sample Date/Time & Value & Units & $\begin{array}{c}\text { Lab } \\
\text { Qualifier }\end{array}$ & \begin{tabular}{|l|} 
Review \\
Qualifier
\end{tabular} \\
\hline 699-S31-E11 & cis-1,2-Dichloroethylene & 8260_VOA_GCMS & 6/19/1998 7:41 AM & 0.1 & $u g / L$ & $U$ & \\
\hline 699-S31-E11 & cis-1,2-Dichloroethylene & 8260_VOA_GCMS & 6/19/1998 7:41 AM & 0.1 & $u g / L$ & $U$ & \\
\hline 699-S31-E11 & cis-1,2-Dichloroethylene & 8260_VOA_GCMS & 6/15/1999 9:49 AM & 0.15 & ug/L & $U$ & \\
\hline 699-S31-E11 & cis-1,2-Dichloroethylene & 8260_VOA_GCMS & 10/12/2000 12:02 PM & 0.18 & $\mathrm{ug} / \mathrm{L}$ & $U$ & \\
\hline 699-S31-E11 & cis-1,2-Dichloroethylene & 8260_VOA_GCMS & 5/1/2001 9:50 AM & 0.18 & $\mathrm{ug} / \mathrm{L}$ & $U$ & \\
\hline 699-S31-E11 & cis-1,2-Dichloroethylene & 8260_VOA_GCMS & 7/25/2002 11:38 AM & 0.24 & $\mathrm{ug} / \mathrm{L}$ & $U$ & \\
\hline 699-S31-E11 & cis-1,2-Dichloroethylene & 8260_VOA_GCMS & 7/31/2003 11:12 AM & 0.06 & ug/L & $U$ & \\
\hline 699-S31-E11 & cis-1,2-Dichloroethylene & 8260_VOA_GCMS & 7/15/2004 12:04 PM & 0.1 & ug/L & $U$ & \\
\hline 699-S31-E11 & cis-1,2-Dichloroethylene & 8260_VOA_GCMS & 9/29/2005 10:42 AM & 0.27 & $\mathrm{ug} / \mathrm{L}$ & $U$ & \\
\hline 699-S31-E11 & cis-1,2-Dichloroethylene & 8260_VOA_GCMS & 3/29/2006 10:57 AM & 0.19 & ug/L & $U$ & \\
\hline 699-S27-E12A & trans-1,2-Dichloroethylene & 8260_VOA_GCMS & 6/22/1998 1:28 PM & 0.13 & $\mathrm{ug} / \mathrm{L}$ & $U$ & \\
\hline 699-S27-E12A & trans-1,2-Dichloroethylene & 8260_VOA_GCMS & 6/22/1998 1:28 PM & 0.13 & $\mathrm{ug} / \mathrm{L}$ & $U$ & \\
\hline 699-S27-E12A & trans-1,2-Dichloroethylene & 8260_VOA_GCMS & 6/14/1999 10:07 AM & 0.11 & ug/L & $U$ & \\
\hline 699-S27-E12A & trans-1,2-Dichloroethylene & 8260_VOA_GCMS & 10/11/2000 10:05 AM & 0.26 & ug/L & $U$ & \\
\hline 699-S27-E12A & trans-1,2-Dichloroethylene & 8260_VOA_GCMS & 4/30/2001 1:16 PM & 0.26 & ug/L & $U$ & \\
\hline 699-S27-E12A & trans-1,2-Dichloroethylene & 8260_VOA_GCMS & $7 / 25 / 2002$ 10:36 AM & 0.23 & $\mathrm{ug} / \mathrm{L}$ & $U$ & \\
\hline 699-S27-E12A & trans-1,2-Dichloroethylene & 8260_VOA_GCMS & 7/21/2003 12:52 PM & 0.17 & ug/L & $U$ & \\
\hline 699-S27-E12A & trans-1,2-Dichloroethylene & 8260_VOA_GCMS & 7/14/2004 11:01 AM & 0.09 & $\mathrm{ug} / \mathrm{L}$ & $U$ & \\
\hline 699-S27-E12A & trans-1,2-Dichloroethylene & 8260_VOA_GCMS & 9/29/2005 9:55 AM & 0.08 & ug/L & $U$ & \\
\hline 699-S27-E12A & trans-1,2-Dichloroethylene & 8260_VOA_GCMS & 11/6/2006 12:12 PM & 0.16 & ug/L & $U$ & \\
\hline 699-S28-E12 & trans-1,2-Dichloroethylene & 502.2_VOA_GC & 7/30/1993 9:30 AM & 0.5 & ug/L & $U$ & \\
\hline 699-S28-E12 & trans-1,2-Dichloroethylene & 502.2_VOA_GC & 5/10/1994 8:30 AM & 0.5 & ug/L & $U$ & \\
\hline 699-S28-E12 & trans-1,2-Dichloroethylene & 502.2_VOA_GC & 10/17/1994 8:50 AM & 0.5 & ug/L & $U$ & \\
\hline 699-S28-E12 & trans-1,2-Dichloroethylene & 502.2_VOA_GC & 1/26/1995 8:40 AM & 0.5 & ug/L & $U$ & \\
\hline 699-S28-E12 & trans-1,2-Dichloroethylene & 8010_VOA_GC & 1/17/1996 10:50 AM & 0.045 & ug/L & $U$ & \\
\hline 699-S28-E12 & trans-1,2-Dichloroethylene & 8260_VOA_GCMS & 6/19/1998 8:25 AM & 0.13 & $\mathrm{ug} / \mathrm{L}$ & $U$ & \\
\hline 699-S28-E12 & trans-1,2-Dichloroethylene & 8260_VOA_GCMS & 6/30/1998 7:52 AM & 0.13 & $\mathrm{ug} / \mathrm{L}$ & $U$ & \\
\hline 699-S28-E12 & trans-1,2-Dichloroethylene & 8260_VOA_GCMS & 6/14/1999 8:50 AM & 0.11 & ug/L & $U$ & \\
\hline 699-S28-E12 & trans-1,2-Dichloroethylene & 8260_VOA_GCMS & 10/11/2000 9:23 AM & 0.26 & $u g / L$ & $\mathrm{U}$ & \\
\hline 699-S28-E12 & trans-1,2-Dichloroethylene & 8260_VOA_GCMS & 5/2/2001 11:53 AM & 0.26 & ug/L & $U$ & \\
\hline 699-S28-E12 & trans-1,2-Dichloroethylene & 8260_VOA_GCMS & $7 / 25 / 20028: 53 \mathrm{AM}$ & 0.23 & ug/L & $U$ & \\
\hline 699-S28-E12 & trans-1,2-Dichloroethylene & 8260_VOA_GCMS & $7 / 25 / 20028: 53 \mathrm{AM}$ & 0.23 & $\mathrm{ug} / \mathrm{L}$ & $U$ & \\
\hline 699-S28-E12 & trans-1,2-Dichloroethylene & 8260_VOA_GCMS & 9/10/2003 10:21 AM & 0.17 & $\mathrm{ug} / \mathrm{L}$ & $U$ & \\
\hline 699-S28-E12 & trans-1,2-Dichloroethylene & 8260_VOA_GCMS & 7/13/2004 11:46 AM & 0.09 & $\mathrm{ug} / \mathrm{L}$ & $U$ & \\
\hline 699-S28-E12 & trans-1,2-Dichloroethylene & 8260_VOA_GCMS & 7/14/2005 10:59 AM & 0.08 & $\mathrm{ug} / \mathrm{L}$ & $U$ & \\
\hline 699-S28-E12 & trans-1,2-Dichloroethylene & 8260_VOA_GCMS & 11/6/2006 12:50 PM & 0.16 & ug/L & $U$ & \\
\hline 699-S28-E13A & trans-1,2-Dichloroethylene & 8260_VOA_GCMS & 6/19/1998 1:17 PM & 0.13 & ug/L & $U$ & \\
\hline 699-S28-E13A & trans-1,2-Dichloroethylene & 8260_VOA_GCMS & 6/14/1999 9:26 AM & 0.11 & ug/L & $U$ & \\
\hline 699-S28-E13A & trans-1,2-Dichloroethylene & 8260_VOA_GCMS & 10/11/2000 11:19 AM & 0.26 & $\mathrm{ug} / \mathrm{L}$ & $U$ & \\
\hline 699-S28-E13A & trans-1,2-Dichloroethylene & 8260_VOA_GCMS & 4/30/2001 12:04 PM & 0.26 & ug/L & $\mathrm{U}$ & \\
\hline 699-S28-E13A & trans-1,2-Dichloroethylene & 8260_VOA_GCMS & $7 / 25 / 2002$ 10:54 AM & 0.23 & $\mathrm{ug} / \mathrm{L}$ & $U$ & \\
\hline 699-S28-E13A & trans-1,2-Dichloroethylene & 8260_VOA_GCMS & 7/17/2003 11:20 AM & 0.17 & ug/L & $U$ & \\
\hline 699-S28-E13A & trans-1,2-Dichloroethylene & 8260_VOA_GCMS & 7/13/2004 10:57 AM & 0.09 & $\mathrm{ug} / \mathrm{L}$ & $U$ & \\
\hline 699-S28-E13A & trans-1,2-Dichloroethylene & 8260_VOA_GCMS & 9/29/2005 9:08 AM & 0.08 & ug/L & $U$ & \\
\hline 699-S28-E13A & trans-1,2-Dichloroethylene & 8260_VOA_GCMS & 8/31/2006 11:20 AM & 0.16 & $\mathrm{ug} / \mathrm{L}$ & $U$ & \\
\hline 699-S29-E10A & trans-1,2-Dichloroethylene & 8260_VOA_GCMS & 6/22/1998 12:39 PM & 0.13 & $\mathrm{ug} / \mathrm{L}$ & U & \\
\hline 699-S29-E10A & trans-1,2-Dichloroethylene & 8260_VOA_GCMS & 6/14/1999 10:44 AM & 0.11 & ug/L & $\mathrm{U}$ & \\
\hline 699-S29-E10A & trans-1,2-Dichloroethylene & 8260_VOA_GCMS & 10/11/2000 8:00 AM & 0.26 & ug/L & $U$ & \\
\hline 699-S29-E10A & trans-1,2-Dichloroethylene & 8260_VOA_GCMS & 5/2/2001 9:05 AM & 0.26 & ug/L & U & \\
\hline 699-S29-E10A & trans-1,2-Dichloroethylene & 8260_VOA_GCMS & 5/2/2001 9:05 AM & 0.26 & ug/L & $U$ & \\
\hline 699-S29-E10A & trans-1,2-Dichloroethylene & 8260_VOA_GCMS & 7/25/2002 11:35 AM & 0.23 & $\mathrm{ug} / \mathrm{L}$ & $U$ & \\
\hline 699-S29-E10A & trans-1,2-Dichloroethylene & 8260_VOA_GCMS & 7/17/2003 1:08 PM & 0.17 & $\mathrm{ug} / \mathrm{L}$ & $U$ & \\
\hline 699-S29-E10A & trans-1,2-Dichloroethylene & 8260_VOA_GCMS & 7/13/2004 12:28 PM & 0.09 & $\mathrm{ug} / \mathrm{L}$ & $\mathrm{U}$ & \\
\hline 699-S29-E10A & trans-1,2-Dichloroethylene & 8260_VOA_GCMS & 9/29/2005 11:23 AM & 0.08 & $\mathrm{ug} / \mathrm{L}$ & $\mathrm{U}$ & \\
\hline 699-S29-E10A & trans-1,2-Dichloroethylene & 8260_VOA_GCMS & 11/30/2006 11:10 AM & 0.16 & ug/L & U & \\
\hline 699-S29-E11 & trans-1,2-Dichloroethylene & 8260_VOA_GCMS & 9/16/1992 9:35 AM & 0.5 & ug/L & $U$ & \\
\hline 699-S29-E11 & trans-1,2-Dichloroethylene & 8240_VOA_GCMS & 12/9/1992 10:02 AM & 10 & $\mathrm{ug} / \mathrm{L}$ & UJ & \\
\hline 699-S29-E11 & trans-1,2-Dichloroethylene & 8260_VOA_GCMS & 12/1/1993 11:40 AM & 1 & ug/L & $\mathrm{U}$ & \\
\hline 699-S29-E11 & trans-1,2-Dichloroethylene & 8260_VOA_GCMS & 3/23/1994 9:07 AM & 1 & $\mathrm{ug} / \mathrm{L}$ & $U$ & \\
\hline 699-S29-E11 & trans-1,2-Dichloroethylene & 8260_VOA_GCMS & 10/11/1994 9:11 AM & & $u g / L$ & $U$ & \\
\hline
\end{tabular}




\begin{tabular}{|c|c|c|c|c|c|c|c|}
\hline Well Name & Constituent & Method Name & Sample Date/Time & Value & Units & $\begin{array}{c}\text { Lab } \\
\text { Qualifier }\end{array}$ & $\begin{array}{l}\text { Review } \\
\text { Qualifier }\end{array}$ \\
\hline 699-S29-E11 & trans-1,2-Dichloroethylene & 8260_VOA_GCMS & 10/11/1994 9:45 AM & & ug/L & $\mathrm{U}$ & \\
\hline 699-S29-E11 & trans-1,2-Dichloroethylene & 502.2_VOA_GC & 10/18/1994 12:01 PM & 0.5 & ug/L & $\mathrm{U}$ & \\
\hline 699-S29-E11 & trans-1,2-Dichloroethylene & 8260_VOA_GCMS & 4/10/1995 11:00 AM & 2.7 & ug/L & & \\
\hline 699-S29-E11 & trans-1,2-Dichloroethylene & 8010_VOA_GC & 3/4/1996 9:05 AM & 0.045 & ug/L & $\mathrm{U}$ & \\
\hline 699-S29-E11 & trans-1,2-Dichloroethylene & 8010_VOA_GC & 1/20/1997 10:54 AM & 0.2 & ug/L & $\mathrm{U}$ & \\
\hline 699-S29-E11 & trans-1,2-Dichloroethylene & 8260_VOA_GCMS & 1/19/1998 9:22 AM & 0.13 & ug/L & $\mathrm{U}$ & \\
\hline 699-S29-E11 & trans-1,2-Dichloroethylene & 8260_VOA_GCMS & 1/20/1999 11:38 AM & 0.05 & ug/L & $\mathrm{U}$ & \\
\hline 699-S29-E11 & trans-1,2-Dichloroethylene & 8260_VOA_GCMS & 5/2/2001 12:51 PM & 0.26 & ug/L & $\mathrm{U}$ & \\
\hline 699-S29-E11 & trans-1,2-Dichloroethylene & 8260 VOA GCMS & 7/25/2002 12:16 PM & 0.23 & ug/L & $\mathrm{U}$ & \\
\hline 699-S29-E11 & trans-1,2-Dichloroethylene & 8260_VOA_GCMS & $7 / 25 / 2002$ 12:16 PM & 0.23 & ug/L & $\mathrm{U}$ & \\
\hline 699-S29-E11 & trans-1,2-Dichloroethylene & 8260_VOA_GCMS & 7/17/2003 12:24 PM & 0.17 & ug/L & $\mathrm{U}$ & \\
\hline 699-S29-E11 & trans-1,2-Dichloroethylene & 8260_VOA_GCMS & 7/13/2004 11:45 AM & 0.09 & ug/L & $\mathrm{U}$ & \\
\hline 699-S29-E11 & trans-1,2-Dichloroethylene & 8260_VOA_GCMS & 7/14/2005 11:54 AM & 0.08 & ug/L & $\mathrm{U}$ & \\
\hline 699-S29-E11 & trans-1,2-Dichloroethylene & 8260_VOA_GCMS & 12/27/2006 1:20 PM & 0.16 & ug/L & $\mathrm{U}$ & \\
\hline 699-S29-E12 & trans-1,2-Dichloroethylene & 8240 VOA GCMS & 1/17/1989 12:00 AM & & ug/L & $\mathrm{U}$ & \\
\hline 699-S29-E12 & trans-1,2-Dichloroethylene & 8240_VOA_GCMS & 5/24/1989 12:00 AM & & ug/L & $\mathrm{U}$ & \\
\hline 699-S29-E12 & trans-1,2-Dichloroethylene & 8260_VOA_GCMS & 5/14/1992 9:19 AM & 0.5 & ug/L & $\mathrm{U}$ & \\
\hline 699-S29-E12 & trans-1,2-Dichloroethylene & 8260_VOA_GCMS & 9/15/1992 5:40 AM & 0.5 & ug/L & $\mathrm{U}$ & \\
\hline 699-S29-E12 & trans-1,2-Dichloroethylene & 8240_VOA_GCMS & 12/9/1992 10:58 AM & 10 & ug/L & $\mathrm{U}$ & \\
\hline 699-S29-E12 & trans-1,2-Dichloroethylene & 502.2_VOA_GC & 8/24/1993 12:46 PM & 0.5 & ug/L & $\mathrm{U}$ & \\
\hline 699-S29-E12 & trans-1,2-Dichloroethylene & 8260 VOA GCMS & 12/1/1993 9:30 AM & & ug/L & $\mathrm{U}$ & \\
\hline 699-S29-E12 & trans-1,2-Dichloroethylene & 8260_VOA_GCMS & 3/22/1994 12:45 PM & 1 & ug/L & $\mathrm{U}$ & \\
\hline 699-S29-E12 & trans-1,2-Dichloroethylene & 502.2_VOA_GC & 5/11/1994 8:30 AM & 0.5 & ug/L & $\mathrm{U}$ & \\
\hline 699-S29-E12 & trans-1,2-Dichloroethylene & 8260_VOA_GCMS & 6/8/1994 10:40 AM & 0.4 & ug/L & $\mathrm{U}$ & \\
\hline 699-S29-E12 & trans-1,2-Dichloroethylene & 8260_VOA_GCMS & 10/12/1994 12:15 PM & 1 & ug/L & $\mathrm{U}$ & \\
\hline 699-S29-E12 & trans-1,2-Dichloroethylene & 502.2_VOA_GC & 1/18/1995 8:00 AM & 0.5 & ug/L & $\mathrm{U}$ & \\
\hline 699-S29-E12 & trans-1,2-Dichloroethylene & 8260_VOA_GCMS & 4/11/1995 12:00 PM & 2.7 & ug/L & $\mathrm{U}$ & \\
\hline 699-S29-E12 & trans-1,2-Dichloroethylene & 8260_VOA_GCMS & 4/11/1995 1:15 PM & 2.7 & ug/L & $\mathrm{U}$ & \\
\hline 699-S29-E12 & trans-1,2-Dichloroethylene & 8010_VOA_GC & 1/15/1996 9:10 AM & 0.045 & $\mathrm{ug} / \mathrm{L}$ & $\mathrm{U}$ & \\
\hline 699-S29-E12 & trans-1,2-Dichloroethylene & 8010_VOA_GC & 1/16/1997 9:20 AM & 0.2 & $\mathrm{ug} / \mathrm{L}$ & $\mathrm{U}$ & \\
\hline 699-S29-E12 & trans-1,2-Dichloroethylene & 8010_VOA_GC & 1/16/1997 9:20 AM & 0.2 & $u g / L$ & $\mathrm{U}$ & \\
\hline 699-S29-E12 & trans-1,2-Dichloroethylene & 8260_VOA_GCMS & 1/12/1998 12:23 PM & 0.13 & $\mathrm{ug} / \mathrm{L}$ & $\mathrm{U}$ & \\
\hline 699-S29-E12 & trans-1,2-Dichloroethylene & 8260_VOA_GCMS & 1/20/1999 9:17 AM & 0.05 & $\mathrm{ug} / \mathrm{L}$ & $\mathrm{U}$ & \\
\hline 699-S29-E12 & trans-1,2-Dichloroethylene & 8260_VOA_GCMS & $7 / 25 / 2002$ 9:45 AM & 0.23 & $\mathrm{ug} / \mathrm{L}$ & $\mathrm{U}$ & \\
\hline 699-S29-E12 & trans-1,2-Dichloroethylene & 8260_VOA_GCMS & 7/21/2003 12:10 PM & 0.17 & $\mathrm{ug} / \mathrm{L}$ & $\mathrm{U}$ & \\
\hline 699-S29-E12 & trans-1,2-Dichloroethylene & 8260_VOA_GCMS & 7/13/2004 10:01 AM & 0.09 & $\mathrm{ug} / \mathrm{L}$ & $\mathrm{U}$ & \\
\hline 699-S29-E12 & trans-1,2-Dichloroethylene & 8260_VOA_GCMS & 11/18/2005 10:51 AM & 0.08 & ug/L & $\mathrm{U}$ & \\
\hline 699-S29-E12 & trans-1,2-Dichloroethylene & 8260_VOA_GCMS & 11/6/2006 1:32 PM & 0.16 & $\mathrm{ug} / \mathrm{L}$ & $\mathrm{U}$ & \\
\hline 699-S29-E13A & trans-1,2-Dichloroethylene & 8260_VOA_GCMS & $6 / 24 / 1998$ 8:37 AM & 0.13 & $\mathrm{ug} / \mathrm{L}$ & $\mathrm{U}$ & \\
\hline 699-S29-E13A & trans-1,2-Dichloroethylene & 8260_VOA_GCMS & 6/15/1999 8:27 AM & 0.11 & $u g / L$ & $\mathrm{U}$ & \\
\hline 699-S29-E13A & trans-1,2-Dichloroethylene & 8260_VOA_GCMS & 6/15/1999 8:27 AM & 0.11 & $u g / L$ & $\mathrm{U}$ & \\
\hline 699-S29-E13A & trans-1,2-Dichloroethylene & 8260_VOA_GCMS & 10/11/2000 12:38 PM & 0.26 & $\mathrm{ug} / \mathrm{L}$ & $\mathrm{U}$ & \\
\hline 699-S29-E13A & trans-1,2-Dichloroethylene & 8260_VOA_GCMS & 10/11/2000 12:38 PM & 0.26 & ug/L & $\mathrm{U}$ & \\
\hline 699-S29-E13A & trans-1,2-Dichloroethylene & 8260_VOA_GCMS & 5/2/2001 10:46 AM & 0.26 & ug/L & $\mathrm{U}$ & \\
\hline 699-S29-E13A & trans-1,2-Dichloroethylene & 8260_VOA_GCMS & $7 / 25 / 2002$ 10:17 AM & 0.23 & ug/L & $\mathrm{U}$ & \\
\hline 699-S29-E13A & trans-1,2-Dichloroethylene & 8260_VOA_GCMS & 7/22/2003 12:34 PM & 0.17 & $\mathrm{ug} / \mathrm{L}$ & $\mathrm{U}$ & \\
\hline 699-S29-E13A & trans-1,2-Dichloroethylene & 8260_VOA_GCMS & 7/14/2004 11:47 AM & 0.09 & $\mathrm{ug} / \mathrm{L}$ & $\mathrm{U}$ & \\
\hline 699-S29-E13A & trans-1,2-Dichloroethylene & 8260_VOA_GCMS & 9/29/2005 12:40 PM & 0.08 & $\mathrm{ug} / \mathrm{L}$ & $\mathrm{U}$ & \\
\hline 699-S29-E13A & trans-1,2-Dichloroethylene & 8260_VOA_GCMS & 11/6/2006 11:18 AM & 0.16 & ug/L & $\mathrm{U}$ & \\
\hline 699-S30-E10A & trans-1,2-Dichloroethylene & 8260_VOA_GCMS & 5/13/1992 8:57 AM & 0.5 & $\mathrm{ug} / \mathrm{L}$ & $\mathrm{U}$ & \\
\hline 699-S30-E10A & trans-1,2-Dichloroethylene & 8260_VOA_GCMS & 9/14/1992 9:00 AM & 0.5 & $\mathrm{ug} / \mathrm{L}$ & $\mathrm{U}$ & \\
\hline 699-S30-E10A & trans-1,2-Dichloroethylene & 8240_VOA_GCMS & 12/7/1992 11:05 AM & 10 & $\mathrm{ug} / \mathrm{L}$ & $\mathrm{U}$ & \\
\hline 699-S30-E10A & trans-1,2-Dichloroethylene & 502.2_VOA_GC & 7/30/1993 8:45 AM & 0.5 & $\mathrm{ug} / \mathrm{L}$ & $\mathrm{U}$ & \\
\hline 699-S30-E10A & trans-1,2-Dichloroethylene & 8260_VOA_GCMS & 12/2/1993 9:00 AM & 1 & $u g / L$ & $\mathrm{U}$ & \\
\hline 699-S30-E10A & trans-1,2-Dichloroethylene & 8260_VOA_GCMS & 3/21/1994 12:25 PM & 1 & ug/L & U & \\
\hline 699-S30-E10A & trans-1,2-Dichloroethylene & 8260_VOA_GCMS & 6/6/1994 12:00 PM & 0.4 & ug/L & UJ & \\
\hline 699-S30-E10A & trans-1,2-Dichloroethylene & 502.2_VOA_GC & 7/11/1994 8:45 AM & 0.5 & $\mathrm{ug} / \mathrm{L}$ & $\mathrm{U}$ & \\
\hline 699-S30-E10A & trans-1,2-Dichloroethylene & 8260_VOA_GCMS & 10/11/1994 1:15 PM & 1 & $u g / L$ & $\mathrm{U}$ & \\
\hline 699-S30-E10A & trans-1,2-Dichloroethylene & 502.2_VOA_GC & 1/16/1995 8:50 AM & 0.5 & ug/L & $\mathrm{U}$ & \\
\hline 699-S30-E10A & trans-1,2-Dichloroethylene & 8260_VOA_GCMS & 4/10/1995 11:43 AM & 2.7 & $\mathrm{ug} / \mathrm{L}$ & & \\
\hline
\end{tabular}




\begin{tabular}{|c|c|c|c|c|c|c|c|}
\hline Well Name & Constituent & Method Name & Sample Date/Time & Value & Units & $\begin{array}{c}\text { Lab } \\
\text { Qualifier }\end{array}$ & $\begin{array}{l}\text { Review } \\
\text { Qualifier }\end{array}$ \\
\hline 699-S30-E10A & trans-1,2-Dichloroethylene & 8010_VOA_GC & 1/12/1996 1:00 PM & 0.045 & ug/L & $U$ & \\
\hline 699-S30-E10A & trans-1,2-Dichloroethylene & 8240_VOA_GCMS & 5/22/1996 9:06 AM & & $\mathrm{ug} / \mathrm{L}$ & $U$ & \\
\hline 699-S30-E10A & trans-1,2-Dichloroethylene & 8260_VOA_GCMS & 6/22/1998 11:18 AM & 0.13 & $\mathrm{ug} / \mathrm{L}$ & $U$ & \\
\hline 699-S30-E10A & trans-1,2-Dichloroethylene & 8260_VOA_GCMS & 6/22/1998 11:18 AM & 0.13 & $\mathrm{ug} / \mathrm{L}$ & $U$ & \\
\hline 699-S30-E10A & trans-1,2-Dichloroethylene & 8260_VOA_GCMS & 6/14/1999 12:27 PM & 0.11 & $u g / L$ & $U$ & \\
\hline 699-S30-E10A & trans-1,2-Dichloroethylene & 8260_VOA_GCMS & 10/11/2000 12:09 PM & 0.26 & $\mathrm{ug} / \mathrm{L}$ & $U$ & \\
\hline 699-S30-E10A & trans-1,2-Dichloroethylene & 8260_VOA_GCMS & 5/1/2001 11:45 AM & 0.26 & ug/L & $U$ & \\
\hline 699-S30-E10A & trans-1,2-Dichloroethylene & 8260_VOA_GCMS & 7/31/2002 10:49 AM & 0.23 & $\mathrm{ug} / \mathrm{L}$ & $U$ & \\
\hline 699-S30-E10A & trans-1,2-Dichloroethylene & 8260_VOA_GCMS & 7/22/2003 9:55 AM & 0.17 & $\mathrm{ug} / \mathrm{L}$ & $U$ & \\
\hline 699-S30-E10A & trans-1,2-Dichloroethylene & 8260_VOA_GCMS & 7/15/2004 11:12 AM & 0.09 & $\mathrm{ug} / \mathrm{L}$ & $U$ & \\
\hline 699-S30-E10A & trans-1,2-Dichloroethylene & 8260_VOA_GCMS & 7/14/2005 11:32 AM & 0.08 & $\mathrm{ug} / \mathrm{L}$ & $U$ & \\
\hline 699-S30-E10A & trans-1,2-Dichloroethylene & 8260_VOA_GCMS & 11/6/2006 12:11 PM & 0.16 & ug/L & $U$ & \\
\hline 699-S30-E10B & trans-1,2-Dichloroethylene & 8260_VOA_GCMS & 5/13/1992 9:50 AM & 0.5 & $\mathrm{ug} / \mathrm{L}$ & $U$ & \\
\hline 699-S30-E10B & trans-1,2-Dichloroethylene & 8260_VOA_GCMS & 9/14/1992 10:00 AM & 0.5 & ug/L & $U$ & \\
\hline 699-S30-E10B & trans-1,2-Dichloroethylene & 8240_VOA_GCMS & 12/7/1992 11:45 AM & 10 & ug/L & $U$ & \\
\hline 699-S30-E10B & trans-1,2-Dichloroethylene & 502.2_VOA_GC & 7/30/1993 8:30 AM & 0.5 & ug/L & $U$ & \\
\hline 699-S30-E10B & trans-1,2-Dichloroethylene & 8260_VOA_GCMS & 12/2/1993 9:40 AM & 1 & $u g / L$ & $U$ & \\
\hline 699-S30-E10B & trans-1,2-Dichloroethylene & 8260_VOA_GCMS & 3/21/1994 11:15 AM & & $\mathrm{ug} / \mathrm{L}$ & $U$ & \\
\hline 699-S30-E10B & trans-1,2-Dichloroethylene & 8260_VOA_GCMS & 6/6/1994 1:25 AM & 0.4 & ug/L & $U$ & \\
\hline 699-S30-E10B & trans-1,2-Dichloroethylene & 502.2_VOA_GC & 7/8/1994 9:45 AM & 0.5 & ug/L & $U$ & \\
\hline 699-S30-E10B & trans-1,2-Dichloroethylene & 8260_VOA_GCMS & 10/11/1994 12:40 PM & & ug/L & $U$ & \\
\hline 699-S30-E10B & trans-1,2-Dichloroethylene & 502.2_VOA_GC & 1/16/1995 8:15 AM & 0.5 & ug/L & $U$ & \\
\hline 699-S30-E10B & trans-1,2-Dichloroethylene & 8260_VOA_GCMS & 4/10/1995 12:30 PM & 2.7 & ug/L & & \\
\hline 699-S30-E10B & trans-1,2-Dichloroethylene & 8240_VOA_GCMS & 5/22/1996 10:25 AM & 5 & $\mathrm{ug} / \mathrm{L}$ & $U$ & \\
\hline 699-S30-E10B & trans-1,2-Dichloroethylene & 8010_VOA_GC & 1/20/1997 11:26 AM & 0.2 & ug/L & $U$ & \\
\hline 699-S30-E10B & trans-1,2-Dichloroethylene & 8260_VOA_GCMS & 1/20/1998 9:40 AM & 0.13 & $\mathrm{ug} / \mathrm{L}$ & $U$ & \\
\hline 699-S30-E10B & trans-1,2-Dichloroethylene & 8260_VOA_GCMS & 1/20/1998 9:40 AM & 0.13 & $\mathrm{ug} / \mathrm{L}$ & $U$ & \\
\hline 699-S30-E10B & trans-1,2-Dichloroethylene & 8260_VOA_GCMS & 1/20/1999 12:21 PM & 0.05 & ug/L & $U$ & \\
\hline 699-S30-E10B & trans-1,2-Dichloroethylene & 8260_VOA_GCMS & 5/2/2001 10:05 AM & 0.26 & ug/L & $U$ & \\
\hline 699-S30-E10B & trans-1,2-Dichloroethylene & 8260_VOA_GCMS & 7/31/2002 10:13 AM & 0.23 & $\mathrm{ug} / \mathrm{L}$ & $U$ & \\
\hline 699-S30-E10B & trans-1,2-Dichloroethylene & 8260_VOA_GCMS & 7/21/2003 12:15 PM & 0.17 & ug/L & $U$ & \\
\hline 699-S30-E10B & trans-1,2-Dichloroethylene & 8260_VOA_GCMS & 7/15/2004 10:35 AM & 0.09 & $\mathrm{ug} / \mathrm{L}$ & $U$ & \\
\hline 699-S30-E10B & trans-1,2-Dichloroethylene & 8260_VOA_GCMS & $7 / 25 / 2005$ 11:00 AM & 0.08 & $\mathrm{ug} / \mathrm{L}$ & $U$ & \\
\hline 699-S30-E10B & trans-1,2-Dichloroethylene & 8260_VOA_GCMS & 11/6/2006 12:53 PM & 0.16 & ug/L & $U$ & \\
\hline 699-S30-E11A & trans-1,2-Dichloroethylene & 8260_VOA_GCMS & 6/19/1998 12:40 PM & 0.13 & $\mathrm{ug} / \mathrm{L}$ & $U$ & \\
\hline 699-S30-E11A & trans-1,2-Dichloroethylene & 8260_VOA_GCMS & 6/14/1999 11:20 AM & 0.11 & $\mathrm{ug} / \mathrm{L}$ & $U$ & \\
\hline 699-S30-E11A & trans-1,2-Dichloroethylene & 8260_VOA_GCMS & 10/11/2000 1:08 PM & 0.26 & ug/L & $U$ & \\
\hline 699-S30-E11A & trans-1,2-Dichloroethylene & 8260_VOA_GCMS & 5/1/2001 10:43 AM & 0.26 & ug/L & $U$ & \\
\hline 699-S30-E11A & trans-1,2-Dichloroethylene & 8260_VOA_GCMS & 7/25/2002 12:03 PM & 0.23 & $\mathrm{ug} / \mathrm{L}$ & $U$ & \\
\hline 699-S30-E11A & trans-1,2-Dichloroethylene & 8260_VOA_GCMS & 9/10/2003 11:31 AM & 0.17 & $\mathrm{ug} / \mathrm{L}$ & U & \\
\hline 699-S30-E11A & trans-1,2-Dichloroethylene & 8260_VOA_GCMS & 7/14/2004 11:55 AM & 0.09 & $\mathrm{ug} / \mathrm{L}$ & $U$ & \\
\hline 699-S30-E11A & trans-1,2-Dichloroethylene & 8260_VOA_GCMS & 9/29/2005 11:50 AM & 0.08 & $\mathrm{ug} / \mathrm{L}$ & $U$ & \\
\hline 699-S30-E11A & trans-1,2-Dichloroethylene & 8260_VOA_GCMS & 11/6/2006 2:22 PM & 0.16 & ug/L & U & \\
\hline 699-S31-E10A & trans-1,2-Dichloroethylene & 8240_VOA_GCMS & 3/10/1992 9:18 AM & 0.5 & ug/L & $U$ & \\
\hline 699-S31-E10A & trans-1,2-Dichloroethylene & 8260_VOA_GCMS & 5/11/1992 12:03 PM & 0.5 & $\mathrm{ug} / \mathrm{L}$ & $U$ & \\
\hline 699-S31-E10A & trans-1,2-Dichloroethylene & 8260_VOA_GCMS & 5/11/1992 12:03 PM & 0.5 & $\mathrm{ug} / \mathrm{L}$ & $U$ & \\
\hline 699-S31-E10A & trans-1,2-Dichloroethylene & 8260_VOA_GCMS & 9/14/1992 1:00 PM & 0.5 & $\mathrm{ug} / \mathrm{L}$ & $U$ & \\
\hline 699-S31-E10A & trans-1,2-Dichloroethylene & 8260_VOA_GCMS & 9/14/1992 1:00 PM & 0.5 & ug/L & $U$ & \\
\hline 699-S31-E10A & trans-1,2-Dichloroethylene & 8240_VOA_GCMS & 12/8/1992 10:00 AM & 10 & ug/L & $U$ & \\
\hline 699-S31-E10A & trans-1,2-Dichloroethylene & 8240_VOA_GCMS & 3/16/1993 9:10 AM & 10 & $\mathrm{ug} / \mathrm{L}$ & $U$ & \\
\hline 699-S31-E10A & trans-1,2-Dichloroethylene & 502.2_VOA_GC & 8/3/1993 9:10 AM & 0.5 & $\mathrm{ug} / \mathrm{L}$ & $U$ & \\
\hline 699-S31-E10A & trans-1,2-Dichloroethylene & 8260_VOA_GCMS & 11/30/1993 10:40 AM & 5 & $\mathrm{ug} / \mathrm{L}$ & $U$ & \\
\hline 699-S31-E10A & trans-1,2-Dichloroethylene & 8260_VOA_GCMS & $11 / 30 / 1993$ 10:40 AM & 1 & ug/L & & \\
\hline 699-S31-E10A & trans-1,2-Dichloroethylene & 8260_VOA_GCMS & 3/22/1994 9:50 AM & 0.4 & $\mathrm{ug} / \mathrm{L}$ & $U$ & \\
\hline 699-S31-E10A & trans-1,2-Dichloroethylene & 8260_VOA_GCMS & 3/22/1994 9:50 AM & & ug/L & $U$ & \\
\hline 699-S31-E10A & trans-1,2-Dichloroethylene & 8260_VOA_GCMS & 6/7/1994 9:46 AM & 0.4 & $\mathrm{ug} / \mathrm{L}$ & $U$ & \\
\hline 699-S31-E10A & trans-1,2-Dichloroethylene & 502.2_VOA_GC & 7/26/1994 8:45 AM & 0.5 & $\mathrm{ug} / \mathrm{L}$ & $U$ & \\
\hline 699-S31-E10A & trans-1,2-Dichloroethylene & 8260_VOA_GCMS & 10/12/1994 10:15 AM & 1 & ug/L & $U$ & \\
\hline 699-S31-E10A & trans-1,2-Dichloroethylene & 8260_VOA_GCMS & 4/12/1995 9:30 AM & 1 & $\mathrm{ug} / \mathrm{L}$ & & \\
\hline 699-S31-E10A & trans-1,2-Dichloroethylene & 8260_VOA_GCMS & 4/12/1995 9:30 AM & 2.7 & ug/L & & \\
\hline
\end{tabular}




\begin{tabular}{|c|c|c|c|c|c|c|c|}
\hline Well Name & Constituent & Method Name & Sample Date/Time & Value & Units & $\begin{array}{c}\text { Lab } \\
\text { Qualifier }\end{array}$ & $\begin{array}{l}\text { Review } \\
\text { Qualifier }\end{array}$ \\
\hline 699-S31-E10A & trans-1,2-Dichloroethylene & 8010_VOA_GC & 11/17/1995 12:00 PM & 0.045 & ug/L & $U$ & \\
\hline 699-S31-E10A & trans-1,2-Dichloroethylene & 8260_VOA_GCMS & 6/22/1998 10:37 AM & 0.13 & $\mathrm{ug} / \mathrm{L}$ & $U$ & \\
\hline 699-S31-E10A & trans-1,2-Dichloroethylene & 8260_VOA_GCMS & 6/22/1998 10:37 AM & 0.13 & $\mathrm{ug} / \mathrm{L}$ & $U$ & \\
\hline 699-S31-E10A & trans-1,2-Dichloroethylene & 8260_VOA_GCMS & 6/14/1999 11:48 AM & 0.11 & $\mathrm{ug} / \mathrm{L}$ & $U$ & \\
\hline 699-S31-E10A & trans-1,2-Dichloroethylene & 8260_VOA_GCMS & 10/11/2000 11:21 AM & 0.26 & ug/L & $U$ & \\
\hline 699-S31-E10A & trans-1,2-Dichloroethylene & 8260_VOA_GCMS & 5/1/2001 11:13 AM & 0.26 & $\mathrm{ug} / \mathrm{L}$ & $U$ & \\
\hline 699-S31-E10A & trans-1,2-Dichloroethylene & 8260_VOA_GCMS & 7/26/2002 12:24 PM & 0.23 & $\mathrm{ug} / \mathrm{L}$ & $U$ & \\
\hline 699-S31-E10A & trans-1,2-Dichloroethylene & 8260_VOA_GCMS & 7/22/2003 10:16 AM & 0.17 & $\mathrm{ug} / \mathrm{L}$ & $U$ & \\
\hline 699-S31-E10A & trans-1,2-Dichloroethylene & 8260_VOA_GCMS & 7/14/2004 12:32 PM & 0.09 & $\mathrm{ug} / \mathrm{L}$ & $U$ & \\
\hline 699-S31-E10A & trans-1,2-Dichloroethylene & 8260_VOA_GCMS & 9/29/2005 9:21 AM & 0.08 & $\mathrm{ug} / \mathrm{L}$ & $U$ & \\
\hline 699-S31-E10A & trans-1,2-Dichloroethylene & 8260_VOA_GCMS & 3/29/2006 12:28 PM & 0.16 & ug/L & $U$ & \\
\hline 699-S31-E10C & trans-1,2-Dichloroethylene & 8240_VOA_GCMS & 3/10/1992 11:36 AM & 5 & ug/L & $U$ & \\
\hline 699-S31-E10C & trans-1,2-Dichloroethylene & 8260_VOA_GCMS & 5/12/1992 10:27 AM & 0.5 & ug/L & $U$ & \\
\hline 699-S31-E10C & trans-1,2-Dichloroethylene & 8260_VOA_GCMS & 5/12/1992 10:27 AM & 0.5 & ug/L & $U$ & \\
\hline 699-S31-E10C & trans-1,2-Dichloroethylene & 8260_VOA_GCMS & 9/14/1992 10:55 AM & 0.5 & ug/L & $U$ & \\
\hline 699-S31-E10C & trans-1,2-Dichloroethylene & 8260_VOA_GCMS & 9/14/1992 10:55 AM & 0.5 & ug/L & $U$ & \\
\hline 699-S31-E10C & trans-1,2-Dichloroethylene & 8240_VOA_GCMS & 12/7/1992 9:58 AM & 10 & $u g / L$ & $U$ & \\
\hline 699-S31-E10C & trans-1,2-Dichloroethylene & 502.2_VOA_GC & 8/3/1993 8:40 AM & 0.5 & $\mathrm{ug} / \mathrm{L}$ & $U$ & \\
\hline 699-S31-E10C & trans-1,2-Dichloroethylene & 8260_VOA_GCMS & 11/30/1993 9:40 AM & 1 & ug/L & & \\
\hline 699-S31-E10C & trans-1,2-Dichloroethylene & 8260_VOA_GCMS & 11/30/1993 9:40 AM & & ug/L & & \\
\hline 699-S31-E10C & trans-1,2-Dichloroethylene & 8260_VOA_GCMS & 3/21/1994 10:22 AM & & ug/L & $U$ & \\
\hline 699-S31-E10C & trans-1,2-Dichloroethylene & 8260_VOA_GCMS & 3/21/1994 10:22 AM & 1 & ug/L & $U$ & \\
\hline 699-S31-E10C & trans-1,2-Dichloroethylene & 8260_VOA_GCMS & 6/6/1994 9:22 AM & 0.4 & ug/L & $U$ & \\
\hline 699-S31-E10C & trans-1,2-Dichloroethylene & 8260_VOA_GCMS & 6/6/1994 9:22 AM & 0.4 & $\mathrm{ug} / \mathrm{L}$ & $U$ & \\
\hline 699-S31-E10C & trans-1,2-Dichloroethylene & 502.2_VOA_GC & 7/8/1994 8:30 AM & 0.5 & ug/L & $U$ & \\
\hline 699-S31-E10C & trans-1,2-Dichloroethylene & 8260_VOA_GCMS & 10/11/1994 11:50 AM & & ug/L & $U$ & \\
\hline 699-S31-E10C & trans-1,2-Dichloroethylene & 8260_VOA_GCMS & 10/11/1994 2:00 PM & & ug/L & $U$ & \\
\hline 699-S31-E10C & trans-1,2-Dichloroethylene & 502.2_VOA_GC & 1/23/1995 8:16 AM & 0.5 & ug/L & $U$ & \\
\hline 699-S31-E10C & trans-1,2-Dichloroethylene & 8260_VOA_GCMS & 4/11/1995 11:30 AM & 2.7 & $u g / L$ & & \\
\hline 699-S31-E10C & trans-1,2-Dichloroethylene & 8260_VOA_GCMS & 6/19/1998 10:06 AM & 0.13 & $\mathrm{ug} / \mathrm{L}$ & $U$ & \\
\hline 699-S31-E10C & trans-1,2-Dichloroethylene & 8260_VOA_GCMS & 6/14/1999 11:01 AM & 0.11 & ug/L & $U$ & \\
\hline 699-S31-E10C & trans-1,2-Dichloroethylene & 8260_VOA_GCMS & 10/11/2000 10:31 AM & 0.26 & $\mathrm{ug} / \mathrm{L}$ & $U$ & \\
\hline 699-S31-E10C & trans-1,2-Dichloroethylene & 8260_VOA_GCMS & 5/1/2001 10:30 AM & 0.26 & $\mathrm{ug} / \mathrm{L}$ & $U$ & \\
\hline 699-S31-E10C & trans-1,2-Dichloroethylene & 8260_VOA_GCMS & 7/26/2002 11:45 AM & 0.23 & $\mathrm{ug} / \mathrm{L}$ & $U$ & \\
\hline 699-S31-E10C & trans-1,2-Dichloroethylene & 8260_VOA_GCMS & 7/22/2003 9:21 AM & 0.17 & $\mathrm{ug} / \mathrm{L}$ & $U$ & \\
\hline 699-S31-E10C & trans-1,2-Dichloroethylene & 8260_VOA_GCMS & 7/14/2004 10:50 AM & 0.09 & $\mathrm{ug} / \mathrm{L}$ & $U$ & \\
\hline 699-S31-E10C & trans-1,2-Dichloroethylene & 8260_VOA_GCMS & 7/19/2005 11:54 AM & 0.08 & ug/L & $U$ & $G$ \\
\hline 699-S31-E10C & trans-1,2-Dichloroethylene & 8260_VOA_GCMS & 11/18/2005 11:35 AM & 0.08 & $\mathrm{ug} / \mathrm{L}$ & $U$ & \\
\hline 699-S31-E10C & trans-1,2-Dichloroethylene & 8260_VOA_GCMS & 11/30/2006 9:24 AM & 0.16 & $\mathrm{ug} / \mathrm{L}$ & $U$ & \\
\hline 699-S31-E10D & trans-1,2-Dichloroethylene & 8240_VOA_GCMS & 3/10/1992 12:56 PM & 0.5 & $\mathrm{ug} / \mathrm{L}$ & U & \\
\hline 699-S31-E10D & trans-1,2-Dichloroethylene & 8260_VOA_GCMS & 5/12/1992 9:28 AM & 0.5 & $\mathrm{ug} / \mathrm{L}$ & U & \\
\hline 699-S31-E10D & trans-1,2-Dichloroethylene & 8260_VOA_GCMS & 9/14/1992 2:43 PM & 0.5 & ug/L & $U$ & \\
\hline 699-S31-E10D & trans-1,2-Dichloroethylene & 8240_VOA_GCMS & 12/7/1992 9:20 AM & 10 & ug/L & $U$ & \\
\hline 699-S31-E10D & trans-1,2-Dichloroethylene & 502.2_VOA_GC & 8/3/1993 9:40 AM & 0.5 & ug/L & $U$ & \\
\hline 699-S31-E10D & trans-1,2-Dichloroethylene & 8260_VOA_GCMS & 11/30/1993 9:00 AM & & $\mathrm{ug} / \mathrm{L}$ & & \\
\hline 699-S31-E10D & trans-1,2-Dichloroethylene & 8260_VOA_GCMS & 3/21/1994 9:20 AM & & ug/L & $U$ & \\
\hline 699-S31-E10D & trans-1,2-Dichloroethylene & 8260_VOA_GCMS & 6/6/1994 10:50 AM & 0.4 & $\mathrm{ug} / \mathrm{L}$ & $U$ & \\
\hline 699-S31-E10D & trans-1,2-Dichloroethylene & 502.2_VOA_GC & 7/8/1994 8:00 AM & 0.5 & ug/L & $U$ & \\
\hline 699-S31-E10D & trans-1,2-Dichloroethylene & 8260_VOA_GCMS & 10/11/1994 10:50 AM & & ug/L & $U$ & \\
\hline 699-S31-E10D & trans-1,2-Dichloroethylene & 502.2_VOA_GC & 1/23/1995 8:40 AM & 0.5 & ug/L & $U$ & \\
\hline 699-S31-E10D & trans-1,2-Dichloroethylene & 8260_VOA_GCMS & 4/11/1995 10:45 AM & 2.7 & $\mathrm{ug} / \mathrm{L}$ & & \\
\hline 699-S31-E10D & trans-1,2-Dichloroethylene & 8260_VOA_GCMS & 6/19/1998 9:07 AM & 0.13 & $\mathrm{ug} / \mathrm{L}$ & $U$ & \\
\hline 699-S31-E10D & trans-1,2-Dichloroethylene & 8260_VOA_GCMS & 6/15/1999 10:32 AM & 0.11 & ug/L & $\mathrm{U}$ & \\
\hline 699-S31-E10D & trans-1,2-Dichloroethylene & 8260_VOA_GCMS & 10/11/2000 9:24 AM & 0.26 & ug/L & $U$ & \\
\hline 699-S31-E10D & trans-1,2-Dichloroethylene & 8260_VOA_GCMS & 5/1/2001 1:21 PM & 0.26 & ug/L & U & \\
\hline 699-S31-E10D & trans-1,2-Dichloroethylene & 8260_VOA_GCMS & 7/26/2002 10:04 AM & 0.23 & $\mathrm{ug} / \mathrm{L}$ & $U$ & \\
\hline 699-S31-E10D & trans-1,2-Dichloroethylene & 8260_VOA_GCMS & $7 / 22 / 20038: 33 \mathrm{AM}$ & 0.17 & ug/L & $U$ & \\
\hline 699-S31-E10D & trans-1,2-Dichloroethylene & 8260_VOA_GCMS & 7/14/2004 9:18 AM & 0.09 & $\mathrm{ug} / \mathrm{L}$ & $U$ & \\
\hline 699-S31-E10D & trans-1,2-Dichloroethylene & 8260_VOA_GCMS & 9/29/2005 8:44 AM & 0.08 & $\mathrm{ug} / \mathrm{L}$ & $U$ & \\
\hline 699-S31-E10D & trans-1,2-Dichloroethylene & 8260_VOA_GCMS & 3/29/2006 11:51 AM & 0.16 & ug/L & $U$ & \\
\hline
\end{tabular}




\begin{tabular}{|c|c|c|c|c|c|c|c|}
\hline Well Name & Constituent & Method Name & Sample Date/Time & Value & Units & $\begin{array}{c}\text { Lab } \\
\text { Qualifier }\end{array}$ & $\begin{array}{l}\text { Review } \\
\text { Qualifier }\end{array}$ \\
\hline 699-S31-E11 & trans-1,2-Dichloroethylene & 8260_VOA_GCMS & 5/11/1992 12:00 AM & 0.5 & ug/L & U & \\
\hline 699-S31-E11 & trans-1,2-Dichloroethylene & $8260 \_$VOA_GCMS & 5/11/1992 12:00 AM & 0.5 & ug/L & $U$ & \\
\hline 699-S31-E11 & trans-1,2-Dichloroethylene & 8260_VOA_GCMS & 9/16/1992 10:35 AM & 0.5 & ug/L & $U$ & \\
\hline 699-S31-E11 & trans-1,2-Dichloroethylene & 8260_VOA_GCMS & 12/1/1993 10:50 AM & & $\mathrm{ug} / \mathrm{L}$ & $U$ & \\
\hline 699-S31-E11 & trans-1,2-Dichloroethylene & 502.2_VOA_GC & 10/17/1994 8:15 AM & 0.5 & ug/L & $U$ & \\
\hline 699-S31-E11 & trans-1,2-Dichloroethylene & 8260_VOA_GCMS & 4/10/1995 10:00 AM & 2.7 & $\mathrm{ug} / \mathrm{L}$ & & \\
\hline 699-S31-E11 & trans-1,2-Dichloroethylene & $8260 \_$VOA_GCMS & 6/19/1998 7:41 AM & 0.13 & ug/L & $\mathrm{U}$ & \\
\hline 699-S31-E11 & trans-1,2-Dichloroethylene & 8260_VOA_GCMS & 6/19/1998 7:41 AM & 0.13 & $\mathrm{ug} / \mathrm{L}$ & $U$ & \\
\hline 699-S31-E11 & trans-1,2-Dichloroethylene & 8260_VOA_GCMS & 6/15/1999 9:49 AM & 0.11 & $\mathrm{ug} / \mathrm{L}$ & $U$ & \\
\hline 699-S31-E11 & trans-1,2-Dichloroethylene & 8260_VOA_GCMS & 10/12/2000 12:02 PM & 0.26 & ug/L & $U$ & \\
\hline 699-S31-E11 & trans-1,2-Dichloroethylene & 8260_VOA_GCMS & 5/1/2001 9:50 AM & 0.26 & ug/L & $U$ & \\
\hline 699-S31-E11 & trans-1,2-Dichloroethylene & 8260_VOA_GCMS & 7/25/2002 11:38 AM & 0.23 & $\mathrm{ug} / \mathrm{L}$ & $U$ & \\
\hline 699-S31-E11 & trans-1,2-Dichloroethylene & 8260_VOA_GCMS & 7/31/2003 11:12 AM & 0.17 & ug/L & $U$ & \\
\hline 699-S31-E11 & trans-1,2-Dichloroethylene & 8260_VOA_GCMS & 7/15/2004 12:04 PM & 0.09 & $\mathrm{ug} / \mathrm{L}$ & $U$ & \\
\hline 699-S31-E11 & trans-1,2-Dichloroethylene & 8260_VOA_GCMS & 9/29/2005 10:42 AM & 0.08 & $\mathrm{ug} / \mathrm{L}$ & $U$ & \\
\hline 699-S31-E11 & trans-1,2-Dichloroethylene & 8260_VOA_GCMS & 3/29/2006 10:57 AM & 0.16 & ug/L & $U$ & \\
\hline \multicolumn{8}{|c|}{$\begin{array}{l}\mathrm{B}=\text { The analyte was detected at a value less than the contract-required detection limit, but greater than or equal to the } \\
\text { instrument detection limit/minimum detection limit. } \\
\mathrm{D}=\text { Analyte was identified in an analysis at a secondary dilution factor (i.e., dilution factor different than 1.0). } \\
\mathrm{E}=\text { Concentration exceeds the calibration range of the GC/MS. } \\
\mathrm{G}=\text { Result is value according to further review. } \\
\mathrm{J}=\text { Estimated value; constituent detected at a level less than the required detection limit or practical quantitation limit and } \\
\text { greater than or equal to the minimum detection limit. } \\
\mathrm{Q}=\text { Associated quality control limit is out of limits. } \\
\mathrm{U}=\text { Analyzed for but not detected above limiting criteria. } \\
\mathrm{UJ}=\text { The result was non-detected, but the detection limit field was estimated. }\end{array}$} \\
\hline
\end{tabular}




\section{Distribution}

No. of

Copies

2 U.S. Department of Energy

R. D. Hildebrand

J. Zeisloft

2 Fluor Hanford, Inc.

L. C. Swanson

J. A. Winterhalder
No. of

Copies

5 Pacific Northwest National Laboratory

A6-38

A3-04

. S. Fruchter

K6-96

S. P. Luttrell

D. R. Newcomer

Hanford Technical Library (2)
K6-96

K6-96

P8-55
E6-35

E6-35 